\title{
REGULATION OF METABOLISM IN ESTIVATING LAND SNAILS: ROLE OF REVERSIBLE PROTEIN PHOSPHORYLATION
}

\author{
By \\ Christopher Jerome Ramnanan
}

B.Sc. (Hons.), 2002

A Thesis Submitted to the Faculty of Graduate Studies and Research in partial fulfillment of the requirements for the degree of

\author{
Doctor of Philosophy \\ Department of Biology \\ Carleton University \\ Ottawa, Ontario, Canada
}

(C) copyright 2006

Christopher Jerome Ramnanan 


$\begin{array}{ll}\begin{array}{l}\text { Library and } \\ \text { Archives Canada }\end{array} & \begin{array}{l}\text { Bibliothèque et } \\ \text { Archives Canada }\end{array} \\ \begin{array}{l}\text { Published Heritage } \\ \text { Branch }\end{array} & \begin{array}{l}\text { Direction du } \\ \text { Patrimoine de l'édition }\end{array} \\ \begin{array}{l}\text { 395 Wellington Street } \\ \text { Ottawa ON K1A 0N4 } \\ \text { Canada }\end{array} & \begin{array}{l}\text { 395, rue Wellington } \\ \text { Ottawa ON K1A ON4 } \\ \text { Canada }\end{array}\end{array}$

Your file Votre référence ISBN: 978-0-494-18232-1 Our file Notre référence ISBN: 978-0-494-18232-1

NOTICE:

The author has granted a nonexclusive license allowing Library and Archives Canada to reproduce, publish, archive, preserve, conserve, communicate to the public by telecommunication or on the Internet, loan, distribute and sell theses worldwide, for commercial or noncommercial purposes, in microform, paper, electronic and/or any other formats.

The author retains copyright ownership and moral rights in this thesis. Neither the thesis nor substantial extracts from it may be printed or otherwise reproduced without the author's permission.
AVIS:

L'auteur a accordé une licence non exclusive permettant à la Bibliothèque et Archives Canada de reproduire, publier, archiver, sauvegarder, conserver, transmettre au public par télécommunication ou par l'Internet, prêter, distribuer et vendre des thèses partout dans le monde, à des fins commerciales ou autres, sur support microforme, papier, électronique et/ou autres formats.

L'auteur conserve la propriété du droit d'auteur et des droits moraux qui protège cette thèse. $\mathrm{Ni}$ la thèse ni des extraits substantiels de celle-ci ne doivent être imprimés ou autrement reproduits sans son autorisation.
In compliance with the Canadian

Privacy Act some supporting forms may have been removed from this thesis.

While these forms may be included in the document page count, their removal does not represent any loss of content from the thesis.
Conformément à la loi canadienne sur la protection de la vie privée, quelques formulaires secondaires ont été enlevés de cette thèse.

Bien que ces formulaires aient inclus dans la pagination, il n'y aura aucun contenu manquant.

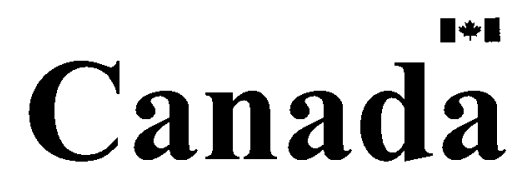




\begin{abstract}
Estivation is a state of aerobic dormancy used by animals such as the desert land snail, Otala lactea, to endure harsh environmental conditions. Metabolic rate depression is key to survival during estivation and requires coordinated suppression of ATPgenerating and ATP-consuming cellular functions by stable regulatory mechanisms. Current studies examined the role of reversible protein phosphorylation in metabolic arrest in snail organs focusing on a major ATP-consuming process, the $\mathrm{Na}^{+} / \mathrm{K}^{+}$-ATPase; a key enzyme that produces NADPH for antioxidant defense, glucose-6-phosphate dehydrogenase (G6PDH); and selected protein kinases and protein phosphatases that could regulate the process. Studies documented a decrease in foot muscle and hepatopancreas $\mathrm{Na}^{+} / \mathrm{K}^{+}$-ATPase activity, and an increase in hepatopancreas G6PDH activity during estivation, as indicated by changes in kinetic parameters (e.g. maximal velocity, substrate affinity, Arrhenius activation energy). Furthermore, in vitro incubations stimulating specific endogenous kinases and phosphatases implicated roles for PKG and PP1 in estivation-dependent changes in $\mathrm{Na}^{+} / \mathrm{K}^{+}$-ATPase and G6PDH. Ion exchange chromatography of G6PDH revealed two enzyme forms - a high phosphate, high activity form and a low phosphate, low activity form - whose proportions changed in dormant snails. The peak profiles of G6PDH from active and estivating snails were also interconverted after incubations promoting PKG or PP1 activities. Profiles of protein phosphatases in $O$. lactea tissues revealed a general suppression of activity during estivation. For PP1 and PP2A the differential activity in estivation was linked to altered enzyme elution profiles from gel filtration chromatography, indicating that differential association into phosphatase holoenzymes is partly responsible for reduced phosphatase
\end{abstract}


activities in estivation. Type- 1 and type- 2 phosphatases were purified and analyzed; the data generally indicated that the mammalian phosphatase classification system was applicable to $O$. lactea phosphatases. Examination of several protein kinases, utilizing a relatively novel assay method with P81 paper array/phosphor imaging, revealed increased activities of AMPK, PKB, and PKG in estivating $O$. lactea. Increased activities of AMPK and PKB were related to changes in their phosphorylation state and confirmed by changes in activities and/or phosphorylation status of downstream targets. Overall, these studies confirm the integral role of reversible protein phosphorylation in the suppression and reorganization of metabolism during estivation. 


\section{ACKNOWLEDGEMENTS}

I would like to express my appreciation for all the people who supported me

during my (long) tenure in the Storey lab. A big thank you is in order for Janet Storey and Ken Storey, who both exercised near superhuman patience with me and my shenanigans over the years, and did everything they could to help me become a better scientist, to help me realize whatever potential I have, and encouraged me to hitch my wagon to a star. I am also extremely grateful for Jan's superb editing, and for Ken being the best supervisor a guy can have, proud when justified, stern when necessary (perhaps not coincidentally right after long coffee breaks) and whose boundless enthusiasm and energy made the lab environment a fun place to be on a day to day basis.

Part of the fun was the people in the lab, who are some of the best folks and friends I am ever going to have. The old crew, the Maritime veterans from when I was just a pup, Dave, Kevin, Sean, and Am, the people that did their doctorates beside me, Pier, Mamady, and Khalil, the newer generation, Amy, Jacques....just some of the first class people I have had the privilege of working beside. Geez, I have been here a while. Colleagues, peers, buddies, partners in crime. A second family.

Of course, my first family is first for a reason. Their love and support and guidance can't be matched. They always told me that I could be whatever I wanted to be (well, except for Superman, or Super Bowl MVP). Mom, Dad, and Mike, you guys are the greatest. 


\section{TABLE OF CONTENTS}

Title Page

Page

Acceptance Sheet

Abstract

Acknowledgements

Table of Contents

vi

List of Abbreviations

vii

List of Tables

List of Figures

xiii

Chapter 1: General Introduction

Chapter 2: Suppression of $\mathrm{Na}^{+} \mathrm{K}^{+}$-ATPase activity during estivation in the land snail Otala lactea

Chapter 3: Glucose-6-phosphate dehydrogenase regulation in Otala lactea during estivation

Chapter 4: Purification and characterization of type-1 protein phosphatase activity in the estivating land snail Otala lactea

Chapter 5: Type-2 serine/threonine phosphatases and tyrosine protein phosphatase profiles in the estivating snail, Otala lactea

Chapter 6: Protein kinases relevant to metabolic rate depression: estivationdependent responses in Otala lactea

Chapter 7: General Discussion

Publication List

References 


\section{LIST OF ABBREVIATIONS}

ACC - acetyl-CoA carboxylase

AMP, ADP, ATP - adenosine mono-, di-, or triphosphate

AMPK - AMP activated protein kinase

AMPKK - AMPK kinase

AP - alkaline phosphatase

BAD - Bcl-2-associated death protein

CaM - calmodulin

CaMK - calmodulin- and $\mathrm{Ca}^{2+}$ - dependent protein kinase

cAMP - 3', 5'-cyclic adenosine monophosphate

cGMP - 3', 5'-cyclic guanosine monophosphate

$\mathbf{C}_{\mathrm{m}}$ - denaturant concentration required to unfold $50 \%$ of a protein

CREB - cAMP response binding element

CS - citrate synthase

DEAE - diethylaminoethyl

$\mathbf{E}_{\mathbf{a}}$ - Activation energy

EDTA - ethylenediamine tetraacetate

EGF - epidermal growth factor

EGTA - ethyleneglycol bis tetraacetate

ERK - extracellular signal-regulated kinase

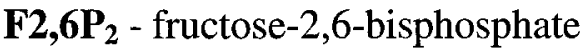

FKHRL1 - Forkhead box, class O protein (FOXO)

G6P - glucose-6-phosphate 
G6PDH - glucose-6-phosphate dehydrogenase

GP - glycogen phosphorylase

GTP - guanosine triphosphate

g.w.m. - gram wet mass

H-7: 1-(5-isoquinolinesulfonyl)-2-methyl piperazine

HEPES - (N-[2-hydroxyethyl] piperazine-N'-[ethansulphonic acid])

HRP - horseradish peroxidase

I-1 - inhibitor-1 (endogenous inhibitor of PP1)

I-2 - inhibitor-2 (endogenous inhibitor of PP1)

$\mathbf{I}_{\mathbf{5 0}}$ - inhibitor concentration reducing enzyme velocity by $50 \%$

IKB - inhibitor of NF-kB

$\mathbf{K}_{\mathrm{a}}$ - activator concentration producing half-maximal enzyme activation

kDa - kiloDalton

$\mathbf{K}_{\mathbf{m}}-$ substrate concentration producing half maximal enzyme activity

LSC - liquid scintillation counting

MAPK - mitogen-activated protein kinase

MOPS - 3-(N-morpholino) propanesulphonic acid

mTOR - mammalian target of rapamycin

$\mathrm{Na}^{+} \mathbf{K}^{+}$-ATPase - ATP-dependent sodium potassium pump

NADP $^{+}, \mathbf{N A D P H}$ - oxidized and reduced nicotinamide adenine dinucleotide phosphate

NaSCN - sodium thiocyanate

NaF - sodium fluoride

$\mathrm{Na}_{3} \mathrm{VO}_{4}$ - sodium orthovanadate 
NF-кB - nuclear factor kappa B

$\left(\mathrm{NH}_{4}\right)_{2} \mathrm{SO}_{4}$ - ammonium sulphate

p70S6K - p70 ribosomal protein S6 kinase

PDH - pyruvate dehydrogenase

PDK1 - phosphoinositide-dependent kinase

PEP - phosphoenolpyruvate

PFK-1 - phosphofructokinase-1

PFK-2 - phosphofructokinase-2

PI - phosphoinositide

PI3K - phosphoinositide 3 kinase

PKA - cAMP-dependent protein kinase

PKAi - PKA inhibitor peptide (fragment 5-24)

PKB - protein kinase B

PKC $-\mathrm{Ca}^{2+}$ - and phospholipid-dependent protein kinase

PKCi - PKC inhibitor peptide (fragment 19-31)

PK - pyruvate kinase

PKG - protein kinase G

PMA - phorbol myristate acetate

PMSF - phenylmethylsulfonyl fluoride

P-NPP - p-nitrophenyl phosphate

PP1 - protein phosphatase type-1

PP1c - PP1 catalytic subunit

PP2A, PP2B, PP2C - protein phosphatase type-2A, -2B and -2C 
PTK - protein tyrosine kinase

PTP - protein tyrosine phosphatase

PVDF - polyvinylidine fluoride

ROS - reactive oxygen species

$\mathbf{S}_{\mathbf{0 . 5}}$ - substrate concentration for half maximal enzyme activity with sigmoidal kinetics

SDS-PAGE - sodium dodecyl sulphate polyacrylamide gel electrophoresis

SH2 - Src homology region

TBST - Tris-buffered saline containing Tween-20

Tris - (Tris[hydroxymethyl]aminomethane)

$\mathbf{V}_{\text {max }}-$ maximal enzyme velocity 


\section{LIST OF TABLES}

TABLE

PAGE

2.1 Kinetic parameters for $\mathrm{Na}^{+} / \mathrm{K}^{+}$-ATPase from foot muscle and hepatopancreas of active and $10 \mathrm{~d}$ estivated $O$. lactea

3.1 Kinetic parameters for G6PDH from hepatopancreas of active and $10 \mathrm{~d}$ estivated $O$. lactea and for Peak I and II G6PDH separated by DEAE chromatography

4.1 Kinetic parameters for PP1-type activity in crude extracts from foot muscle and hepatopancreas of active and $10 \mathrm{~d}$ estivated $O$. lactea

4.2 Purification of type-1 protein phosphatase activity from foot muscle of active $O$. lactea snails

4.3 Kinetic parameters for purified PP1-type activity from foot muscle of active and $10 \mathrm{~d}$ estivated $O$. lactea

4.4 Kinetic parameters for active snail foot muscle PP1-type activity associated with different molecular weights recovered from Sephacryl S-400 gel filtration

5.1 The effect of stripping treatments on recoverable phosphatase activity from $O$. lactea crude soluble extracts

5.2 Kinetic parameters for PP2A-type activity in crude soluble extracts from $O$. lactea foot muscle and hepatopancreas

5.3 Purification of type-2A heparin-binding phosphatase activity from active $O$. lactea foot muscle

5.4 Kinetic parameters for two forms of microcystin-Sepharose eluted PP2A-type activity purified from estivating snail foot muscle

5.5 Kinetic parameters for PP2B activity recovered from crude soluble hepatopancreas extracts of active and $10 \mathrm{~d}$ estivated snails

5.6 Purification of type-2B protein phosphatase from hepatopancreas of active $O$. lactea

5.7 Kinetic parameters for PP2C-type activity from crude soluble extracts of foot muscle and hepatopancreas from active and $10 \mathrm{~d}$ estivated $O$. lactea 
5.8 Purification of active type-2C protein phosphatase activity from $O$. lactea foot muscle

5.9 Kinetic parameters for PTP activity from crude soluble extracts of foot muscle and hepatopancreas from active and $10 \mathrm{~d}$ estivated $O$. lactea

5.10 Distribution of marker enzyme activities recovered in subcellular fractions of $O$. lactea foot muscle

6.1 Kinetic parameters for cGMP-dependent protein kinase from foot muscle and hepatopancreas of active and $10 \mathrm{~d}$ estivated $O$. lactea

6.2 Kinetic parameters for AMP-activated protein kinase from foot muscle and hepatopancreas of active and $10 \mathrm{~d}$ estivated $O$. lactea

6.3 Kinetic parameters for acetyl-CoA carboxylase from foot muscle and hepatopancreas of active and $10 \mathrm{~d}$ estivated $O$. lactea

6.4 Kinetic parameters for PKB from foot muscle and hepatopancreas 182 of active and $10 \mathrm{~d}$ estivated $O$. lactea 


\section{LIST OF FIGURES}

FIGURE

PAGE

2.1 $\mathrm{Na}^{+} \mathrm{K}^{+}$-ATPase activity in hepatopancreas from active and estivated $O$. lactea as a function of assay $\mathrm{pH}$

2.2 $\mathrm{Na}^{+} \mathrm{K}^{+}$-ATPase activity in O. lactea foot muscle and hepatopancreas as a function of Mg.ATP concentration

2.3 Substrate affinity for ATP as a function of temperature for $\mathrm{Na}^{+} \mathrm{K}^{+}$-ATPase activity in $O$. lactea foot muscle and hepatopancreas

2.4 Effect of in vitro incubations to stimulate the activities of endogenous protein kinases and protein phosphatases on $\mathrm{Na}^{+} \mathrm{K}^{+}-$ ATPase activity in $O$. lactea foot muscle extracts

2.5 Effect of in vitro incubations stimulating the activities of endogenous protein kinases and protein phosphatases on $\mathrm{Na}^{+} \mathrm{K}^{+}$ATPase activity in $O$. lactea hepatopancreas extracts

2.6 Effect of calcium concentration on the stimulation by endogenous protein kinases of $\mathrm{Na}^{+} \mathrm{K}^{+}$-ATPase activity in foot muscle extracts from active snails

2.7 Arrhenius plots showing $\mathrm{Na}^{+} \mathrm{K}^{+}$-ATPase maximal activity as a function of temperature for foot muscle and hepatopancreas from o. lactea

2.8 Western blots showing $\mathrm{Na}^{+} \mathrm{K}^{+}$-ATPase protein content in foot muscle and hepatopancreas of $O$. lactea

2.9 Structural unfolding and enzymatic inhibition by urea of foot muscle $\mathrm{Na}^{+} \mathrm{K}^{+}$-ATPase from active and estivating snails

3.1 Determination of optimal $\mathrm{pH}$ for G6PDH activity from hepatopancreas of active and estivated $O$. lactea

3.2 G6PDH activity as a function of substrate concentration (G6P and $\mathrm{NADP}^{+}$) from $O$. lactea hepatopancreas

3.3 Effects of in vitro incubations to stimulate the activities of protein kinases or protein phosphatases on G6PDH activity from $O$. lactea hepatopancreas 
3.4 DEAE-G25 Sephadex elution profiles for G6PDH activity from hepatopancreas of active and estivating $O$. lactea

3.5 Representative Arrhenius plots for $O$. lactea hepatopancreas

G6PDH activity for crude extracts and partially pure peak I and peak II preparations

3.6 Structural unfolding and enzymatic inhibition by urea of peak I and II G6PDH from hepatopancreas of active snails

4.1 Recoverable PP-1 type activity from crude extracts of active and estivating $O$. lactea after different treatments to promote dissociation of regulatory subunits

4.2 Type-1 phosphatase activity from crude extracts of $O$. lactea foot muscle and hepatopancreas measured with different substrates

4.3 Type-1 phosphatase activity recovered from $O$. lactea foot muscle as a function of okadaic acid concentration

4.4 SDS-PAGE with Coomassie blue staining of samples taken at different steps in the analysis of PP1 from foot muscle of active O. lactea snails

4.5 Elution profiles of $O$. lactea type-1 phosphatase activity from a Sephacryl-S400 gel filtration column for foot muscle extracts

5.1 Purification scheme utilized to identify and distinguish different serine/threonine specific phosphatase activities from active and estivating $O$. lactea snails

5.2 PP2A-type phosphatase activity towards different substrates recovered from crude extracts of active and $10 \mathrm{~d}$ estivated $O$. lactea foot muscle and hepatopancreas

5.3 Sephacryl-S400 gel filtration elution profile of type-2A phosphatase activity recovered from $O$. lactea foot muscle

5.4 SDS-PAGE of the purification of PP2A from foot muscle of active $O$. lactea snails

5.5 SDS-PAGE of the purification of PP2B from of active $O$. lactea hepatopancreas 
5.6 Type-2C phosphatase activity, recovered from crude extracts of active and $10 \mathrm{~d}$ estivating $O$. lactea hepatopancreas, as a function of $\mathrm{MnCl}_{2}$ concentration

5.7 SDS-PAGE of the purification of PP2C from foot muscle of active $O$. lactea snails

5.8 Subcellular distribution of phosphatases in foot muscle of active and estivating $O$. lactea

6.1 Representative image of radioactive protein kinase assay captured with the BioRad PhosphoImager

6.2 Arrhenius plots showing PKG maximal activity from O. lactea as a function of temperature

6.3 Effects of $\mathrm{pH}$ and temperature on the PKG $\mathrm{K}_{\mathrm{m}}$ values for the peptide PKISASEFDRPLR for $O$. lactea foot muscle

6.4 lactea foot muscle PKG activity as a function of magnesium concentration

6.5 Effects of $\mathrm{pH}$ and temperature on the $\mathrm{K}_{\mathrm{m}}$ for SAMS peptide of $O$. lactea foot muscle and hepatopancreas AMPK

6.6 Effect of in vitro incubations to stimulate the activities of endogenous protein kinases and protein phosphatases on AMPK in foot muscle extracts from active and estivated $O$. lactea

6.7 Effect of in vitro incubations to assess the effects of stimulating endogenous protein kinases and protein phosphatases on acetylCoA carboxylase maximal activity and $\mathrm{K}_{\mathrm{m}}$ ATP

6.8 Elution profiles for $O$. lactea acetyl-CoA carboxylase activity from foot muscle of active snails off a Sephacryl-S400 gel filtration column

6.9 Effect of incubations to stimulate the activities of endogenous (A) protein kinases and (B) protein phosphatases on PKB activity in foot muscle extracts from active and $10 \mathrm{~d}$ estivated $O$. lactea

6.10 Effect of in vitro incubations to stimulate the activities of endogenous (A) protein kinases and (B) protein phosphatases on $\mathrm{PKB}$ activity in hepatopancreas extracts from active and $10 \mathrm{~d}$ estivated $O$. lactea 
6.11 Analysis of protein levels of PKB and selected downstream protein targets in $O$. lactea foot muscle and hepatopancreas

6.12 Activity of p70S6K in foot muscle and hepatopancreas of active and estivating $O$. lactea

7.1 The AMPK signalling pathway.

7.2 The PKB signalling pathway. 


\section{CHAPTER 1}

\section{General Introduction}


The land snail, Otala lactea, is a native of the seasonally arid lands around the Mediterranean region. When food or water is limiting, this pulmonate gastropod enters estivation, a state of aerobic dormancy. A number of behavioural, physiological, and biochemical adaptations underlie estivation and help to confer prolonged water and energy conservation that allows the snails to survive for many months until favorable environmental conditions return. The phenomenon of estivation is common among both vertebrates and invertebrates and has been well-studied in several terrestrial snails, including O. lactea (Brooks and Storey, 1997; Bishop and Brand, 2000; Storey, 2002; Ramos-Vasconcelos and Hermes-Lima, 2003).

\section{Estivation in 0. lactea}

Because of the limitations in their environments, snails that estivate are typically active for only a few weeks of the year and, during that time, they must accumulate sufficient body fuel reserves to survive for many months in dormancy. Like most estivators, dormancy is triggered in $O$. lactea by sensing lack of food and water in the environment. When this occurs, animals usually seek out sheltered sites that limit their exposure to the elements and to predators and over a period of hours or days settle into a hypometabolic state where metabolic rate is often $<30 \%$ of normal resting rate. O. lactea employs several specific adaptations that facilitate survival during dormancy. At the onset of estivation, snails secrete a calcified mucous membrane, called an epiphragm, which effectively closes the entrance to the shell and helps to limit evaporative water loss. Estivators also typically elevate the solute concentrations of their body fluids, using the colligative properties of dissolved solutes such as urea to aid water retention; e.g. urea 
accumulation during estivation is common in estivating amphibians (Withers and Guppy, 1996). Correlated with this, metabolic enzymes in estivating animals are frequently much more resistant to the denaturing effects of urea, when compared to enzymes in nonestivators (Cowan and Storey, 2002). Desert-dwelling organisms also typically convert nitrogenous wastes into uric acid; excretion and storage of nitrogen in this insoluble form requires minimal water. The kidney is a small organ in gastropods, and has a limited ability to store uric acid. Uric acid accumulates to high levels in foot muscle and other tissues of the estivating Indian apple snail Pila globosa (Athawale and Reddy, 2002).

Evaporative water loss is also minimized by employing discontinuous breathing, where the snail's pneumostome, the specialized oriface leading to the lung, opens for only short periods of time, with long, irregular intervals between openings, allowing for intermittent respiration. Estivating $O$. lactea can take as little as 2-3 breaths per hour (Barnhart and McMahon, 1987). Thus, estivation in O. lactea, while aerobic, is characterized by long periods of apnea that are irregularly interrupted by short periods of $\mathrm{O}_{2}$ and $\mathrm{CO}_{2}$ exchange (Barnhart, 1986).

While physical adaptations such as the epiphragm and behavioural modifications such as the intermittent pneumostome opening contribute to water conservation, these adaptations also decrease ventilation of the lung. As a result, between breaths, snails experience a progressive hypoxia, extracellular and intracellular acidosis, and hypercapnia (Barnhart and McMahon, 1988). Between breaths, the partial pressure of carbon dioxide $\left(\mathrm{PCO}_{2}\right)$ gradually rises and the partial pressure of oxygen $\left(\mathrm{PO}_{2}\right)$ gradually falls in the snail's tissues. The interval length between breaths is determined by oxygen need, and not $\mathrm{CO}_{2}$ levels, as studies have shown that increased oxygen tension reduced 
breath frequency, whereas hypercapnia had no effect (Barnhart, 1986). However, elevation of $\mathrm{PCO}_{2}$ (or the resulting cellular acidosis that this creates) has been implicated as the molecular trigger for the suppression of metabolic rate (Guppy et al., 1994). Thus, oxygen consumption was reduced by $50 \%$ in active $O$. lactea that were exposed to a $\mathrm{PCO}_{2}$ of $65 \mathrm{~mm} \mathrm{Hg}$, but oxygen consumption quickly returned to normal levels upon removal of $\mathrm{CO}_{2}$ (Barnhart and McMahon, 1988). Hence, $\mathrm{CO}_{2}$ retention is an extrinsic factor that can account for a substantial part of the overall metabolic rate depression in estivation. However, oxygen consumption and metabolic rate during estivation is typically reduced to just $5-30 \%$ of the rate in aroused snails (Herreid, 1977) and, therefore, other intrinsic mechanisms of metabolic rate depression are clearly required.

\section{Metabolic rate depression essential for survival in estivators}

Estivating snails in extremely arid environments have been known to sustain continuous dormancy for times ranging from several weeks to several months, and sometimes even years (Herreid, 1977). The finite energy reserves of the animal at the onset of estivation must be sufficient to fuel life-maintaining processes for the duration of dormancy. In vertebrates such as the spadefoot toad, fatty acid oxidation seems to be the chief energy source that maintains life-processes through estivation (Jones, 1980). However, this is not the case in dormant snails, where carbohydrate oxidation was observed to be the key energy reserve in two species of mountain snails, Oreohelix strigosa and $O$. subrudis (Rees and Hand, 1983). When carbohydrate stores were depleted after the first few months of dormancy in these mountain species, protein 
oxidation was then initiated; overall, there was little contribution at any stage from lipid breakdown (Rees and Hand, 1983).

The transition into a hypometabolic state requires coordinated suppression of the rates of both energy consuming and energy producing pathways to create a new lower balanced state of ATP turnover. Furthermore, controls are applied to reorganize the animal's priorities for energy use during the hypometabolic condition, maintaining some cell functions and strongly suppressing others. For example, functions such as protein synthesis are often very strongly suppressed so that a higher proportion of total ATP turnover is reserved for vital functions such as the maintenance of membrane potential difference in the hypometabolic state (Storey and Storey, 2004). This has been well documented, for example, in the response of turtle hepatocytes to anoxia. In these cells, overall metabolic rate was reduced by $94 \%$ in anoxia but the fraction of cellular ATP used by the ATP-dependent sodium-potassium pump ( $\mathrm{Na}^{+} \mathrm{K}^{+}$-ATPase) actually rose from $28 \%$ to $75 \%$ because the rates of less essential biosynthetic processes were almost completely turned off in the hypometabolic state (Hochachka et al., 1996).

Major loci for regulation of metabolic processes are the key regulatory enzymes of different biochemical pathways. Several levels of control can be involved in regulating entry into and/or arousal from dormancy including changes in gene expression, protein synthesis, post-translational modification, and allosteric control of enzymes. Generally, sustained dormancy is not accompanied by wholesale changes in gene transcription. Modification of gene expression patterns is an elaborate, time-consuming process whereas animals that move into a hypometabolic state in response to adverse conditions typically need to make the transition quickly, in response to environmental and 
physiological cues. Thus, control at the level of gene expression is typically limited to just a few selected genes that are turned on. Furthermore, the manufacturing of proteins is energetically demanding, whereas ATP is at a premium for dormant animals. Hence, large scale protein synthesis (and also large scale protein degradation) is not compatible with the animal's need for energy conservation during dormancy. In addition, dormant animals can be aroused rapidly when the environment returns to more favourable conditions; for example, O. lactea arouse within minutes of sensing water (Hermes-Lima et al., 1998). Metabolic capabilities need to be maintained in readiness for a rapid return to normal life and, therefore, major metabolic restructuring does not typically occur during dormancy. Instead, the changes in gene expression and protein content are relatively subtle, and regulation comes instead from reversible controls on metabolism.

Several types of reversible regulatory mechanisms are known to participate in metabolic rate depression. These include (1) modification of enzyme activity via protein phosphorylation or dephosphorylation mediated by protein kinases or protein phosphatases, (2) changes in the binding associations of enzymes in multienzyme complexes or bound to subcellular structural elements, and (3) allosteric regulation of key enzymes such as inhibition of the anabolic use of carbohydrate stores via reduced fructose-2,6-biphosphate (F2,6 $\mathrm{P}_{2}$ ) control over phosphofructokinase-1 (PFK-1) (Storey, 1988). Reversible protein phosphorylation, in particular, has been established as a key mechanism in the estivating snail, and is the focus of the research presented in this thesis. 


\section{Reversible phosphorylation: key mechanism of metabolic regulation}

Reversible protein phosphorylation is an important and far-reaching theme in post-translational regulation across the eukaryotic kingdom. The covalent binding of a phosphate group to an enzyme (mediated by protein kinases) or removal of a phosphate group (catalyzed by protein phosphatases) can have immediate, dramatic effects on enzyme activity and kinetic/regulatory properties, typically modifying enzymes from active (or more active) to inactive (or less active) conformations. Modification of an enzyme via phosphorylation can have substantial effects on the flux of a metabolic pathway, at a much lower energetic cost than by other means of changing enzyme activities (ie. protein synthesis or degradation). Another desirable feature of phosphorylation-mediated control is that the modification is readily reversible, and this allows the animal to respond quickly to environmental cues, and enter (or exit) the dormant state (and adjust metabolic rates) as rapidly (Storey, 2001).

Metabolic pathways are commonly regulated by 1) controlling the rate of substrate entry into the pathway, and/or 2) controlling the rate of enzymatic reaction(s) that influence flux through the pathway. In every metabolic pathway, there is at least one non-equilibrium, highly exergonic (and essentially irreversible, under cellular conditions) reaction catalyzed by a low activity enzyme, the rate of which influences the rate of the entire pathway. These key pathway-controlling enzymes are likely targets for regulatory mechanisms such as feedback allosteric inhibition by endproducts and reversible posttranslational modification. As $O$. lactea relies primarily on aerobic catabolism of carbohydrates for energy to fuel dormancy, it could be expected that enzymatic activities 
influencing the rates of glycolysis and the Krebs cycle would be subject to modification to facilitate transition to the estivating condition.

\section{Regulatory role for phosphorylation established in estivating $\boldsymbol{O}$. lactea}

Several enzymes that can influence the rate of carbohydrate catabolism have been studied in $O$. lactea, and these proteins have all been implicated as targets of estivationresponsive covalent modification. They include glycogen phosphorylase (GP) which regulates the catabolism of glycogen to provide substrate for glycolysis, PFK-1 which is recognized as the key control enzyme of glycolysis, pyruvate kinase (PK) which catalyzes the essentially irreversible reaction at the terminus of glycolysis, and pyruvate dehydrogenase (PDH) which is the entry point for carbohydrate into the Krebs cycle. Activities of GP, PFK-1, PK, and PDH were all reduced in estivating $O$. lactea, and in all cases these were linked to changes in the phosphorylation state of the enzymes (Whitwam and Storey, 1990, 1991; Brooks and Storey, 1992, 1997). All showed at least one of the following features as a result: reduced maximum activities $\left(\mathrm{V}_{\max }\right)$, reduced affinity for substrates or activators (increased $\mathrm{K}_{\mathrm{m}}$ ), or increased sensitivity to feedback inhibition by endproducts and inhibition by metabolites in general (decreased $\mathrm{I}_{50}$ ). For example, both estivation- and anoxia-induced phosphorylation of foot muscle and mantle PK resulted in reduced enzyme affinity for substrates, PEP and ADP, and increased sensitivity to inhibition by Mg-ATP and L-alanine (Whitwam and Storey, 1990). PDH showed a decrease in the percentage of the enzyme in the active, dephosphorylated form - a reduction from $98 \%$ in control tissues to $\sim 60 \%$ during estivation (Brooks and Storey, 1992). 
Given the central importance of reversible protein phosphorylation in the control of carbohydrate catabolism (which regulates ATP supply) in $O$. lactea during estivation, I reasoned that reversible phosphorylation could also regulate other areas of metabolism during dormancy in these snails. Specifically, this would be expected to include key ATP-consuming reactions so that a coordinated suppression of energy-producing and energy-consuming reactions could be achieved to produce a lower, stable, metabolic rate during dormancy. One such ATP-expensive activity is sodium and potassium pumping, catalyzed by the $\mathrm{Na}^{+} \mathrm{K}^{+}$-ATPase.

\section{$\mathrm{Na}^{+} \mathrm{K}^{+}$-ATPase: candidate for suppressed activity in estivation}

$\mathrm{Na}^{+} \mathrm{K}^{+}$-ATPase has a critical vital function in the maintenance of plasma membrane potential difference in all animal cells, pumping $\mathrm{Na}^{+}$and $\mathrm{K}^{+}$against their concentration gradients to maintain high sodium levels outside cells and high potassium inside. The pump consumes a great deal of energy; for example, in resting endotherms it is responsible for 5-40\% of total ATP consumption depending on cell type (Clausen, 1986). The enzyme consists of a large multipass transmembrane catalytic polypeptide (the $\sim 100 \mathrm{kDa} \alpha$-subunit) and a smaller, associated glycoprotein (the $\sim 40-55 \mathrm{kDa} \beta$ subunit). In mammals, four isoforms of the $\alpha$-subunit are known along with three isoforms of the $\beta$-subunit (Claussen, 2003); these combine to create multiple tissuespecific isozymes with different kinetic properties (Lopina, 2001). Homology of the catalytic $\alpha$-subunit is very high ( $\sim 85 \%)$ indicating a need for strong conservation of functional residues. 
$\mathrm{Na}^{+} \mathrm{K}^{+}$-ATPase is subject to short-term regulation via reversible phosphorylation of the catalytic subunit (Ewart and Klip, 1995; Lopina 2001). For example, the $\alpha 1$ isoform of $\mathrm{Na}^{+} \mathrm{K}^{+}$-ATPase which is the dominant form in mammalian kidney can be phosphorylated by cAMP-dependent (PKA), cGMP-dependent (PKG), and $\mathrm{Ca}^{2+}$-and phospholipid-dependent (PKC) protein kinases, as well as tyrosine kinases (Lopina, 2001). Phosphorylation can either inhibit or stimulate $\mathrm{Na}^{+} \mathrm{K}^{+}-\mathrm{ATPase}$ activity, depending on factors such as the type of $\alpha$-isoform present and calcium concentration (Cheng et al., 1999; Lopina, 2001).

In multiple situations of hypometabolism it is clear that transmembrane sodium and potassium gradients are maintained despite much reduced rates of ATP turnover; for example, this has been documented in anoxic turtles (Buck and Hochachka, 1993) and estivating frogs (Flanigan et al., 1993). This requires coordinated suppression of the rates of $\mathrm{Na}^{+}$and $\mathrm{K}^{+}$movements through ion channels (termed channel arrest) and oppositelydirected ATP-driven ion pumps to match the rates of ATP availability from catabolic pathways (Hochachka, 1986). Controlled suppression of $\mathrm{Na}^{+} \mathrm{K}^{+}$-ATPase activity is one critical element in this process and has been documented in hypometabolic systems including turtle anaerobiosis and mammalian hibernation (Hochachka et al., 1996; MacDonald and Storey, 1999a). In the latter case, the mechanism of $\mathrm{Na}^{+} \mathrm{K}^{+}$-ATPase suppression was shown to be protein phosphorylation (MacDonald and Storey, 1999a). Suppression of $\mathrm{Na}^{+} \mathrm{K}^{+}$-ATPase activity could contribute substantially to overall metabolic rate depression in estivating $O$. lactea, and such a reduction is characterized as one part of the studies presented in this thesis. 


\section{Estivation is an oxidative condition}

It is well-established that suppression of the activities of key regulatory enzymes of carbohydrate catabolism in glycolysis (GP, PFK-1, PK) and carbohydrate entry into the Krebs cycle $(\mathrm{PDH})$ is mediated by reversible protein phosphorylation during entry into a hypometabolic state - not just during estivation in $O$. lactea (as discussed above) but also in many other systems (Storey and Storey, 2004). To date, however, the regulation of alternative pathways of carbohydrate catabolism during hypometabolism has not been studied. One pathway, the pentose phosphate pathway (alternatively termed the hexose monophosphate shunt), is of particular relevance to the estivating snail. The pentose phosphate pathway has several important functions, including (i) the production of pentose sugars for synthesis of nucleotides and nucleic acids, (ii) serving as the entry point for dietary nucleotides and 5-carbon sugars into catabolic pathways, (iii) rearranging the carbon skeletons of dietary carbohydrates into glycolytic/gluconeogenic intermediates, and (iv) the generation of reducing equivalents in the form of NADPH (Ozer et al., 2002). NADPH is required by cells for both a wide range of reductive biosyntheses (e.g. fatty acids, steroids) (Aksoy et al., 2001) and for antioxidant reactions. NADPH supplies the reducing power for the production of reduced glutathione and thioredoxin, two of the key antioxidant reducing agents in cells. Biosynthesis is not a priority for dormant animals, but protection against oxidative damage remains key for organisms that must remain viable over many weeks/months in a hypometabolic state (Hermes-Lima et al., 1998; Storey and Storey, 2004).

Indeed, although oxygen consumption is significantly reduced in estivation, and the generation of oxyradicals in tissues is generally proportional to oxygen consumption, 
the activities of a variety of antioxidant enzymes are elevated during estivation in $O$. lactea, including superoxide dismutase and catalase (Hermes-Lima and Storey, 1995; Hermes-Lima et al., 1998). This seems to serve two purposes (Hermes-Lima et al., 1998): (a) to allow animals to cope with a large increase in oxyradical formation associated with arousal from dormancy, when oxygen is rapidly reintroduced in large amounts, and (b) to deal with intermittent sharp increases in tissue oxygenation (and oxyradical formation) brought about by discontinuous breathing patterns during estivation. The latter results because, to minimize water loss during dormancy, the pneumostome opens only intermittently for a rapid exchange of $\mathrm{CO}_{2}$ and $\mathrm{O}_{2}$ in the lung (Barnhart and McMahon, 1987, 1988). For antioxidant defenses to be elevated during estivation, it follows that pools of reducing power must be available, and hence the regulation of the pentose phosphate pathway becomes important. I proposed, therefore, that glucose-6-phosphate dehydrogenase (G6PDH) would be differentially regulated in snail tissues during estivation.

\section{G6PDH and control of the pentose phosphate cycle in $O$. lactea}

$\mathrm{G} 6 \mathrm{PDH}$ is a $\sim 60 \mathrm{kDa}$ cytoplasmic protein that influences the rate of the pentose phosphate pathway, oxidizing glucose-6-phosphate to 6-phosphogluconate and at the same time reducing $\mathrm{NADP}^{+}$to generate $\mathrm{NADPH}$. Recent studies have shown that G6PDH has a critical role in cell growth, particularly in providing the NADPH needed for maintenance of redox regulation and antioxidant defense (Tian et al., 1998). Indeed, G6PDH inhibition contributes to $\mathrm{H}_{2} \mathrm{O}_{2}$-induced cell death (Tian et al., 1999). Several NADPH-dependent mechanisms protect the cell against oxidative stress. NADPH is used 
to replenish the pool of reduced glutathione molecules (GSH) from oxidized glutathione (GSSG). In turn, GSH can function independently as a non-enzymatic scavenger of singlet oxygen molecules (Spolarics, 1998) and is also a substrate for antioxidant enzymes, including glutathione-S-transferase and glutathione peroxidase, that mediate detoxification reactions related to the removal of reactive oxygen species (ROS). NADPH also provides the reducing power for the re-reduction of oxidized thioredoxin (a small protein antioxidant) (Nakamura, 2005) as well as for ROS detoxification reactions and xenobiotic transformation reactions mediated by the cytochrome P450 (CYP450) family of enzymes (Digiulio et al., 1989). CYP450 enzymes are membrane bound and localized in either the endoplasmic reticulum (ER) or the mitochondria; electrons from NADPH are donated to ER CYP450 enzymes via NADPH CYP450 reductase or to mitochondrial CYP450 enzymes via ferrodoxin.

One of the newly recognized mechanisms for controlling G6PDH activity is reversible protein phosphorylation. Recent studies have documented G6PDH inhibition by cAMP-dependent protein kinase (PKA) mediated phosphorylation in mammalian systems including aortic endothelial cells, kidney cortex and macrophages (Costa Rosa et al., 1995; Zhang et al., 2000; Xu et al., 2005). Napier et al. (1987) also reported epidermal growth factor receptor tyrosine kinase mediated phosphorylation of Baker's yeast and bovine adrenal G6PDH. However, although these studies show that G6PDH maximal activity is suppressed by phosphorylation, almost nothing is known to date about the effects of phosphorylation on the kinetic and regulatory parameters of the enzyme or how G6PDH phosphorylation state in cells responds to various external environmental stresses. Hence, one of the goals of the work presented in this thesis was 
to determine how G6PDH was regulated with respect to estivation, whether its phosphorylation state changed during estivation, and how phosphorylation affected $O$. lactea G6PDH properties.

\section{Metabolic control by protein kinases and protein phosphatases}

Given the clear involvement of reversible protein phosphorylation in the regulation of enzymes of carbohydrate metabolism during estivation in $O$. lactea, it is obvious that transitions to/from the hypometabolic state must include changes in the activities of the protein kinases and protein phosphatases that regulate these enzymes. Indeed, studies of other hypometabolic systems support this idea. For example, protein kinases and protein phosphatases have been implicated in regulating metabolic rate depression in several vertebrate (Mehrani and Storey, 1995a; Mehrani and Storey, 1995b; Cowan and Storey, 2001a; MacDonald and Storey, 2002, 2005) and invertebrate models (MacDonald and Storey, 1999b; 2006; Cowan and Storey, 2001b; Larade and Storey, 2006; Pfister and Storey, 2002, 2006a, 2006b).

Cells contain large numbers of protein kinases and phosphatases that are typically organized into signal transduction cascades and act to orchestrate coordinated responses by multiple cell functions to a huge range of extracellular signals including environmental stresses, hormones, etc. (MacDonald, 2004). Signal transduction cascades are typically initiated by binding of effector molecules to membrane receptors, many of which then activate receptor-linked protein tyrosine kinases (PTKs) and protein tyrosine phosphatases (PTPs) (Fischer et al., 1991; Alonso et al., 2004). Receptor PTKs and PTPs subsequently act on a range of targets including nonreceptor PTKs and PTPs which in 
turn act on many other downstream substrates including the serine/threonine specific protein kinases and phosphatases that regulate enzymes in metabolic pathways (Cohen, 1989; Cobb and Goldsmith, 1995).

Multiple downstream serine/threonine specific protein kinases and phosphatases could be involved in regulating the metabolic reorganization that is needed for estivation. Previous studies from our lab have shown differential patterns of protein phosphorylation in active versus estivating $O$. lactea, indicating that changes in the phosphorylation state of many cellular proteins occurs during estivation (Brooks and Storey, 1995). A more direct analysis indicated that neither protein kinase A (PKA) nor protein kinase C (PKC) appeared to be involved in stress-induced suppression of PK activity in O. lactea (Brooks and Storey, 1994). Indeed, levels of second messengers that activate PKA or PKC declined over the early stages of estivation suggesting that the kinases that they control would also be suppressed (Brooks and Storey, 1996). However, levels of cyclic 3'5' guanosine monophosphate, the second messenger of protein kinase $\mathrm{G}(\mathrm{PKG})$ rose during the early hours of estivation (Brooks and Storey, 1996), suggesting a possible signaling role for PKG in the transition to the hypometabolic state. Based on this limited prior information, it is obvious that much remains to be determined about the roles of protein kinases and protein phosphatases in regulating snail estivation. Therefore, I proposed a comprehensive analysis of the responses and/or regulation of selected protein phosphatases (PP1, PP2A, PP2B, PP2C, PTPs) and protein kinases (PKG, AMPK, PKB) and the roles that they might play in $O$. lactea estivation. 


\section{Serine/threonine protein phosphatases}

Serine/threonine phosphatases typically consist of small catalytic subunits that are complexed with one or more regulatory or targeting subunits (Cohen, 1989; Alonso et al., 2004), resulting in a large number of distinct holoenzyme structures that are divided into type- 1 and type- 2 phosphatases based on biochemical properties. Protein phosphatase type 1 (PP1) preferentially dephosphorylates the $\beta$-subunit of glycogen phosphorylase kinase, is ion independent, and is sensitive to nanomolar concentrations of heat-stable endogenous protein inhibitors designated inhibitor-1 and inhibitor-2 (I-1 and I-2). Type-2 phosphatase (PP2) preferentially dephosphorylates the $\alpha$-subunit of phosphorylase kinase and is insensitive to I-1 and I-2 (Cohen, 1989; Shenolikar, 1994). Type-2 phosphatases can be further subdivided into type-2A, type-2B, and type-2C enzymes. PP1 and PP2A (both ion-independent phosphatases) are further differentiated by their sensitivities to inhibition by the marine toxin, okadaic acid. The inhibitor concentration causing a 50\% decrease in activity is 10-100 nM for PP1 versus 0.1-2 nM for PP2A (Cohen et al., 1989; Boudreau and Hoskin, 2005).

PP1 is known to regulate major cellular functions such as glycogen metabolism, protein synthesis, calcium transport, muscle cell contraction and cell division (Cohen, 1989; Barford, 1998). The catalytic subunit of PP1 is active when not bound to inhibitory subunits (I-1 and I-2), and activity is mediated by a regulatory subunit (R) (Hubbard and Cohen, 1993). PP1 activity is also recruited and targeted towards particular substrates via association with subcellular structures; for example, interaction with a glycogen-binding (G) subunit enhances PP1-mediated dephosphorylation and deactivation of glycogenmetabolizing enzymes (Hubbard and Cohen, 1993). 
The three subtypes of PP2 are distinguished based on purification properties, ion requirements, substrate affinities, and sensitivities to pharmacological inhibitors. PP2A is ion-independent and extremely sensitive to okadaic acid. The enzyme is a heterotrimer complex termed 'ABC', with a $38 \mathrm{kDa}$ catalytic subunit (C) complexed to a regulatory 60 $\mathrm{kDa}$ 'A' subunit and a regulatory 'B' subunit of variable size (Kamibayashi et al., 1991). PP2A has many roles including dephosphorylation of enzymes involved in regulating glycolysis, glycogen metabolism, gluconeogenesis, fatty acid synthesis and amino acid breakdown (Cohen, 1989).

PP2B is calcium and calmodulin dependent, and can be inhibited by synthetic pyrethroid chemicals such as cypermethrin and deltamethrin (Enan et al., 1992). Activity is found in most tissues, but is prevalent in the brain; hence, it is commonly referred to as calcineurin. PP2B typically exists as a regulatory subunit and a calcium binding subunit, both of which are necessary for activity. PP2B is not known to dephosphorylate ratedetermining enzymes in metabolic pathways (Cohen, 1989) but it can dephosphorylate proteins such as the regulatory RII subunit of protein kinase A (PKA) and I-1, which allows PP2B to effectively regulate other kinases and phosphatases.

PP2C exists as a catalytic monomer of $45 \mathrm{kDa}$ and is distinct from the other phosphatases in that no regulatory subunits or specific inhibitors have been found to date (Rogers et al., 2006). The role of this phosphatase has not been clearly defined in animal systems, but PP2C can dephosphorylate and thereby regulate proteins in stress response and growth related pathways in plants, fungi, and bacteria. PP2C also dephosphorylates a mitogen activated protein kinase (MAPK) involved in the osmotic stress response in yeast, Saccharomyces cerevisiae (Warmka et al., 2001) and inhibits cell growth by 
activating the p53 pathway in human embryonic 293 kidney cells (Ofec et al., 2003).

PP2C has also been shown to negatively regulate MAPK signaling in invertebrates (Baril and Therrien, 2006).

\section{Protein kinase involvement in estivation: PKG, AMPK, PKB}

Like their phosphatase counterparts, protein kinases are classified as being either tyrosine specific or serine/threonine specific. As discussed above, previous studies failed to indicate a positive role for either PKA or PKC in regulating entry into estivation in $O$. lactea. However, cGMP levels were elevated during the transition into estivation which suggests possible regulatory action by PKG (Brooks and Storey, 1996). Notably, PKG is known to regulate various metabolic responses to anoxia in marine molluscs which suggests a possible conserved role of PKG in metabolic rate depression associated with either anaerobiosis or estivation in molluscs (Brooks and Storey, 1997) Another serine/threonine kinase that may have particular relevance to metabolic control in the estivating snail is the AMP-activated protein kinase (AMPK), which regulates central catabolic and anabolic pathways in response to cellular energy status. In addition, protein kinase $\mathrm{B}(\mathrm{PKB})$, which activates anti-apoptosis mechanisms and serves to promote cell survival, could be involved in extended invertebrate dormancy. Hence, I proposed an investigation of the responses and regulation of these protein kinases in $O$. lactea.

PKG typically exists in mammals as a $150-160 \mathrm{kDa}$ holoenzyme consisting of two identical 75-80 kDa subunits (Gill et al., 1977; Lincoln et al., 1977, 1988). However, PKG from rat intestine was a monomeric protein of $86 \mathrm{kDa}$ (De Jonge, 1981). Each PKG subunit contains a regulatory $(\mathrm{R})$ and a catalytic $(\mathrm{C})$ domain and, thus, has independent 
activity, although dimerization increases sensitivity to cGMP activation (Richie-Jannetta et al., 2003). Soluble guanylate cyclase enzymes catalyze the formation of cGMP from GTP in response to various stimuli (e.g. nitric oxide, hormones such as atrial natriuretic factor) (Schmidt et al., 1993; Vaandrager and De Jonge, 1996). Physiological consequences of PKG activation include smooth muscle relaxation, platelet aggregation induced by nitric oxide-containing vasodilators, intestinal secretion and reabsorption of water and ions, neurotransmission, and regulation of cyclic nucleotide degradation (Lincoln et al., 1996; Hoffman et al., 2000; Stamler and Meissner, 2001).

PKG seems to be central to cellular regulation across the Phylum Mollusca. In particular, PKG has been established in mediating neural functioning in several mollusc models such as Pectin irradians, sea hares of the genus Aplysia, and Helix aspersa (Sung et al., 2004; Gomez and Nasi, 2005). PKG has higher activity than protein kinase A (PKA) in bivalve myocardium (Higgins and Greenberg, 1974) and mediates gill muscle potentiation in the clam Mercenaria mercenaria (Gainey and Greenberg, 2003). Anoxiainduced phosphorylation of PK is stimulated by cGMP in the marine whelk Busycon canaliculatum (Brooks and Storey, 1990). Changes in cGMP levels are associated with anoxia survival in the mussel Mytilus edilus (Holwerda et al., 1981) and with expression of anoxia- and freezing-induced genes in Littorina littorea (Larade and Storey, 2002). In vitro incubation studies have also implicated PKG in the regulation of enzymes in $O$. lactea (Brooks and Storey, 1997). Given the established functions of PKG across the Mollusca, this kinase is a likely candidate to play a significant role in transition to the dormant state in the estivating land snail. 
AMPK is another kinase that could have a significant regulatory role in estivation. AMPK has an established role in regulating the balance between energy-consuming and energy-producing pathways in other animal systems and is directly sensitive to the energy state of the cell. Mammalian AMPK is a trimeric enzyme composed of a catalytic $63 \mathrm{kDa}$ $\alpha$-subunit, a regulatory $40 \mathrm{kDa} \beta$-subunit that can target the enzyme to glycogen (Polekhina et al., 2005), and a $38 \mathrm{kDa} \gamma$-subunit that contains regulatory AMP- and ATPbinding sites (Adams et al., 2004). The trimer structure is also conserved in the invertebrate model D. melanogaster (Hardie and Pan, 2002). AMPK is recognized as a metabolic 'master switch' that, when allosterically activated by elevated AMP levels (indicative of ATP depletion), acts to shut down ATP-consuming processes and activate ATP-generating catabolism (Hardie and Pan, 2002). AMPK is itself modulated by posttranslational modification; the $\alpha$-subunit is phosphorylated by upstream kinases including a specific AMPK kinase (Stein et al., 2000) and myristoylation and phosphorylation of the $\beta$-subunit influences localization and activity (Warden et al., 2001).

AMPK is a sensor and monitor of adenylate energy charge, defined as $[\mathrm{ATP}+0.5$ $\mathrm{ADP}] /[\mathrm{ATP}+\mathrm{AMP}+\mathrm{ADP}]$. This ratio can theoretically vary between values of 0 and 1 and in resting, unstressed cells is typically 0.90-0.95, depending on tissue type. At high energy charge, energy equivalents (ATP) are abundant and anabolic processes are activated, whereas when ATP is depleted, energy charge drops and ATP generating processes are stimulated. When activated at low energy charge, AMPK phosphorylates and inactivates, among others, acetyl-CoA carboxylase, 3-hydroxyl-3-methylglutaryl$\mathrm{CoA}$, glycogen synthase and creatine kinase, enzymes that control anabolic pathways of fatty acid, cholesterol, glycogen, and phosphocreatine synthesis, respectively (Hue et al., 
2002). In addition to short-term effects of AMPK directly phosphorylating and regulating metabolic enzymes, the enzyme also exerts longer term effects on gene expression. For example, in pancreatic $\beta$-cell lines, AMPK inhibits the transcription of fatty acid synthase and L type pyruvate kinase (da Silva et al., 2000).

Thus, AMPK action could be highly relevant to animals that depress metabolic rate and must readjust their energy metabolism, selectively suppressing various energy expensive functions and adjusting to a new much lower rate of ATP turnover. Indeed, AMPK was activated in $D$. melanogaster cell lines in response to various conditions that depleted ATP (Pan and Hardie, 2002), showing that invertebrate AMPK functions similarly to the vertebrate homologue in response to energy stress. However, to date, AMPK has never been characterized in an invertebrate model of hypometabolism.

Known for its ability to regulate and activate cellular survival responses (Brazil et al., 2002), the phosphoinositide 3 kinase (PI3K) (PI) / protein kinase $\mathrm{B}$ (PKB, or Akt) signaling cascade has obvious potential relevance for the maintenance of long term viability in estivating animals. $\mathrm{PKB}$ is a $60 \mathrm{kDa}$ protein composed of a catalytic subunit flanked by N-terminal pleckstrin homology $(\mathrm{PH})$ domain and a short, hydrophobic $\mathrm{C}-$ terminus tail. Several growth factors and hormones (ie. insulin) can lead to PI3K activation, and PI3K mediates PKB activation in two steps. Active PI3K produces 3phosphoinositides which recruit (by binding to the $\mathrm{PH}$ domain of $\mathrm{PKB}$ ) inactive cytoplasmic PKB to the membrane; membrane phospholipids activate the 3phosphoinositide-dependent kinase (PDK1) that phosphorylates and activates PKB. Active PKB has several downstream effects in the regulation of glucose transport, protein synthesis, and cell survival (Hajduch et al., 2001). 
Like AMPK, PKB activity is dependent on phosphorylation state. Activated PKB is known to phosphorylate and interfere with several pro-apoptotic cell factors such as BAD, IKB kinase- $\beta$ (IKK- $\beta$ ), and the FOXO transcription factors (Datta et al., 1999). The survival response mediated by the PI3K/PKB pathway is largely conserved in $D$. melanogaster (Oldham and Hafen, 2003). In hibernating bats, levels of active PKB were decreased in brain, liver, kidney, white adipose tissue, and active PKB was increased in brown adipose tissue (Eddy and Storey, 2003). The role of PKB in estivating invertebrates remains to be clarified.

\section{Aims and Objectives}

Reversible protein phosphorylation has been identified as an important mechanism of metabolic regulation in many animal systems in many physiological states and, in particular, has been shown to have a key role in mediating and coordinating metabolic rate depression in a variety of animals that undergo natural hypometabolism. Previous work from our lab has shown that reversible phosphorylation is important in the regulation of carbohydrate catabolism in $O$. lactea during entry into and arousal from estivation. However, many other aspects of metabolism require coordination and regulation to achieve a stable hypometabolic state. The research described in this thesis has two main aims: (1) to assess the role of reversible phosphorylation in regulating other key areas of metabolism in estivating snails, specifically ion motive ATPases (major consumers of cellular energy) and the pentose phosphate pathway, and (2) to examine the responses and regulation of various serine/threonine protein phosphatases and protein kinases that could be involved in mediating metabolic arrest. 
In studying the serine/threonine protein phosphatases, a novel purification scheme was also developed to effectively separate and identify individual phosphatases. In studying the protein kinases, a new assay method involving phosphor imaging was developed and optimized to assay stress-activated kinase activity.

\section{Hypotheses and Predictions}

I proposed that phosphorylation would play a role in regulating several aspects of metabolism differentially in estivating $O$. lactea, facilitating survival during dormancy. The following predictions were tested in the estivating $O$. lactea model:

1. The activity of $\mathrm{Na}^{+} / \mathrm{K}^{+}$-ATPase, a major energy-consuming reaction in all cells, is suppressed during estivation and the mechanism of regulation is reversible protein phosphorylation.

2. The activity of G6PDH, the rate limiting enzyme of the pentose phosphate pathway, is enhanced in estivation, and the mechanism of regulation is reversible phosphorylation.

3. Type-1 protein phosphatase activity is differentially regulated in estivation, facilitating biochemical modifications that support dormancy.

4. Type-2 protein phosphatase activity is differentially regulated in estivation, facilitating the establishment of the hypometabolic state.

5. Stress-relevant protein kinases are differentially regulated in the estivated condition to coordinate changes in metabolic functions that support long term estivation. 


\section{CHAPTER 2 \\ Suppression of $\mathrm{Na}^{+} \mathrm{K}^{+}$-ATPase activity during estivation in the land snail Otala lactea}




\section{Introduction}

As discussed in Chapter 1, O. lactea can remain dormant for months and sometimes years (Herreid, 1977). Strong metabolic rate suppression is a key feature of estivation and serves to greatly extend the time that a fixed reserve of endogenous fuels can support survival. Estivating snails typically reduce their metabolic rate to $<30 \%$ of the resting rate in nonestivating animals (Rees and Hand, 1990; Brooks and Storey, 1997; Bishop and Brand, 2000). The transition into a hypometabolic state requires coordinated suppression of the rates of both ATP-consuming and ATP-producing cell functions as well as reorganization of the priorities for ATP use (Storey and Storey, 2004). A primary mechanism of metabolic arrest is reversible protein phosphorylation, the importance of this mechanism to the control of estivation in O. lactea having been shown initially in studies of several regulatory enzymes in the ATP-producing pathways of carbohydrate catabolism (Whitwam and Storey, 1990, 1991; Brooks and Storey, 1992, 1997).

$\mathrm{Na}^{+} \mathrm{K}^{+}$-ATPase has a critical function in maintaining plasma membrane potential difference in all animal cells, pumping $\mathrm{Na}^{+}$and $\mathrm{K}^{+}$against their concentration gradients to maintain low $\mathrm{Na}^{+}$and high $\mathrm{K}^{+}$concentrations inside cells. The enzyme is a major consumer of cellular ATP being responsible for 5-40\% of total ATP turnover depending on cell type (Clausen, 1986). $\mathrm{Na}^{+} \mathrm{K}^{+}$-ATPase is subject to short-term regulation via reversible phosphorylation of the catalytic subunit (Ewart and Klip, 1995; Lopina 2001). Phosphorylation of mammalian $\mathrm{Na}^{+} \mathrm{K}^{+}$-ATPase can either inhibit or stimulate activity, depending on factors such as type of $\alpha$-isoform present and calcium concentration (Cheng et al., 1999; Lopina, 2001). The effect of phosphorylation on invertebrate $\mathrm{Na}^{+} \mathrm{K}^{+}$-ATPase has yet to be clarified. 
Controlled suppression of $\mathrm{Na}^{+} \mathrm{K}^{+}$-ATPase activity is a critical element of overall metabolic rate depression in vertebrate tissues and has been documented in turtle anaerobiosis and mammalian hibernation (Hochachka et al., 1996; MacDonald and Storey, 1999). In hibernating mammals, $\mathrm{Na}^{+} \mathrm{K}^{+}$-ATPase suppression was linked with phosphorylation of the enzyme (MacDonald and Storey, 1999a). I hypothesized that $\mathrm{Na}^{+} \mathrm{K}^{+}$-ATPase would also be a key target for control in the tissues of estivating snails and that reversible phosphorylation would be the primary mechanism involved. The present study investigates $\mathrm{Na}^{+} \mathrm{K}^{+}$-ATPase regulation in $O$. lactea foot muscle and hepatopancreas. The kinetic properties of $\mathrm{Na}^{+} \mathrm{K}^{+}$-ATPase from active and estivating snails were characterized and in vitro incubations with protein kinases and phosphatases were used to determine whether changes to the phosphorylation state of the enzyme could account for changes in $\mathrm{Na}^{+} \mathrm{K}^{+}$-ATPase activity between active and estivating states.

\section{Methods and Materials}

\section{Animals and Chemicals}

Otala lactea snails from Morocco were purchased from a local retailer. In the lab the snails were held at room temperature $\left(\sim 22^{\circ} \mathrm{C}\right)$ in plastic containers lined with damp paper towels and fed shredded carrots and cabbage (sprinkled with crushed chalk) every 2-3 days. After one month, estivation was induced in one group of snails by placing them in a container with dry paper towels and no food, whereas active snails were maintained under the same conditions as previously. After 10 days, active and estivating snails were sacrificed by decapitation. Foot muscle and hepatopancreas were rapidly dissected out, immediately frozen in liquid nitrogen, and stored at $-70^{\circ} \mathrm{C}$ until use. Phosphatase 
inhibitors okadaic acid and cypermethrin was purchased from Calbiochem (La Jolla, CA). Antibody raised in mice against $\mathrm{Na}^{+} \mathrm{K}^{+}$-ATPase was purchased from Developmental Studies Hybridoma Bank (University of Iowa) and HRP-conjugated goat anti-mouse secondary antibody was obtained from Santa Cruz Biotechnology (Santa Cruz, CA); all other chemicals were purchased from Sigma (St. Louis, MO, USA).

\section{Sample preparation.}

Frozen samples were homogenized (1:10 w:v) using a Polytron PT1000 homogenizer (Brinkmann Instruments, Rexdale, ON) in ice-cold buffer A ( $25 \mathrm{mM}$ imidazole, $\mathrm{pH} 8.0,10 \% \mathrm{v}: \mathrm{v}$ glycerol, $100 \mathrm{mM}$ sucrose, $10 \mathrm{mM}$ 2-mercaptoethanol) that also contained $0.2 \%$ w:v sodium deoxycholate, 2 mM EDTA, 2 mM EGTA and $25 \mathrm{mM}$ $\mathrm{NaF}$; an aliquot of the protease inhibitor phenylmethylsulfonyl fluoride (PMSF) added just before homogenizing. The concentrations of EDTA, EGTA and NaF used were optimized in preliminary studies. After centrifugation at $10,000 \mathrm{x} \mathrm{g}$, supernatant samples were removed and desalted by low speed centrifugation through small columns of Sephadex G25 to remove endogenous ions and free phosphate. The columns were typically equilibrated in buffer A containing EDTA, EGTA, and $\mathrm{NaF}$ but these were omitted in extracts that were to be used in incubations to promote phosphorylation and dephosphorylation of $\mathrm{Na}^{+} \mathrm{K}^{+}$-ATPase. Extracts were stored on ice $\left(4^{\circ} \mathrm{C}\right)$ until assay.

\section{The ammonium molybdate/malachite green system of inorganic phosphate detection.}

$\mathrm{Na}^{+} \mathrm{K}^{+}$-ATPase activity was measured as the difference between total ATPase activity and ouabain-insensitive (in the presence of $1 \mathrm{mM}$ ouabain) activity, ouabain 
being a known specific inhibitor of $\mathrm{Na}^{+} \mathrm{K}^{+}$-ATPase. Activity was determined as the amount of free phosphate produced as detected using the ammonium molybdate/malachite green phosphate complexing dye. Reagent was prepared and colorimetric assays were performed described by Ekman and Jager (1993). All glassware was prewashed with $4 \mathrm{M} \mathrm{HCl}$. The reagent was prepared by mixing one volume of $10 \%$ $(\mathrm{w} / \mathrm{v})$ ammonium molybdate $\left[(\mathrm{NH} 4)_{6} \mathrm{Mo}_{7} \mathrm{O}_{24} \cdot 4 \mathrm{H}_{2} \mathrm{O}\right]$ in $4 \mathrm{M} \mathrm{HCl}$ with 3 volumes of $0.2 \%$ $(\mathrm{w} / \mathrm{v})$ malachite green in $4 \mathrm{M} \mathrm{HCl}$. After stirring for $30 \mathrm{~min}$ at room temperature, the solution was gravity filtered using Whatman filter paper and stored in a dark, opaque bottle; the light-sensitive dye was stable for up to one month. This red dye reagent turns green after binding inorganic phosphate and the green colour intensity is quantified spectrophotometrically at $595 \mathrm{~nm}$.

\section{$\mathrm{Na}^{+} / \mathrm{K}^{+}$-ATPase assays.}

$\mathrm{Na}^{+} / \mathrm{K}^{+}$-ATPase activity was measured in paired reaction tubes, as described previously (Crombie et al., 1996, Macdonald and Storey, 1999a). For maximum activity measurements, the difference in phosphate production was determined between the blank reaction (no $\mathrm{KCl}, 1 \mathrm{mM}$ ouabain, $120 \mathrm{mM} \mathrm{NaCl}$ ) and the experimental reaction (no oubain, $20 \mathrm{mM} \mathrm{KCl}, 100 \mathrm{mM} \mathrm{NaCl}$ ), both also containing $5 \mathrm{mM} \mathrm{MgCl} 2,5 \mathrm{mM} \mathrm{Mg}$.ATP and $25 \mathrm{mM}$ imidazole-HCl, $\mathrm{pH}$ 7.4. All stock ATP solutions were prepared as 1:1 molar mixtures with $\mathrm{MgCl}_{2}$. Initial experiments optimized and determined linearity of reaction time, enzyme amount, and colour development. Assays were initiated by adding $25 \mu \mathrm{L}$ of desalted enzyme extract to a final assay volume of $250 \mu \mathrm{L}$ in an Eppendorf tube. After 10 min at $22^{\circ} \mathrm{C}$, a $25 \mu \mathrm{L}$ aliquot of reaction mixture was removed and added to a detection 
tube containing $200 \mu \mathrm{L}$ dye reagent and $775 \mu \mathrm{L}$ of $\mathrm{ddH}_{2} \mathrm{O}$. After colour development for $10 \mathrm{~min}, 100 \mu \mathrm{L}$ aliquots were transferred to microplates and absorbance at $595 \mathrm{~nm}$ was measured using a MR5000 microplate reader from Dynatech Laboratories (Chantilly, VA) and Biolinx 2.0 software (Brockville, ON). Phosphate production was determined by comparison with a $\mathrm{KH}_{2} \mathrm{PO}_{4}$ standard curve. All samples were measured in triplicate and averaged. Activity is reported as nmol phosphate released $/ \mathrm{min} / \mathrm{mg}$ soluble protein $(\mathrm{mU}$ $\left.\mathrm{mg}^{-1}\right)$. Protein concentration was quantified using the Coomassie Blue dye binding method and protein prepared reagent from BioRad (Hercules, CA) with a standard curve of bovine serum albumin. Determination of enzyme kinetic parameters $\left(S_{0.5}, K_{m}, K_{a}, I_{50}\right.$, $\mathrm{C}_{\mathrm{m}}$ ) used the Microplate Analysis and Kinetics 3.51 software programs (Brooks, 1992, 1994).

\section{Phosphorylation and dephosphorylation of $\mathrm{Na}^{+} \mathrm{K}^{+}-A T P a s e$}

To assess the effects of protein phosphorylation state on enzyme activity, tissue extracts were prepared in buffer $\mathrm{A}$ and then incubated under conditions that promoted either protein phosphorylation or protein dephosphorylation in vitro (protocol modified from Storey, 1994). Incubation time was $4 \mathrm{~h}$ to assess changes in $\mathrm{V}_{\max }$ in extracts. Enzyme extracts were mixed 1:2 v:v with buffer A with additions as follows.

(A) Control incubations: $25 \mathrm{mM} \mathrm{NaF}, 2 \mathrm{mM}$ EDTA, $2 \mathrm{mM}$ EGTA to inhibit all phosphatase and kinase activities.

(B) Stimulation of endogenous protein kinase activities: $5 \mathrm{mM} \mathrm{Mg.ATP,} 25 \mathrm{mM}$ $\mathrm{NaF}$ and either (1) $1 \mathrm{mM}$ cAMP to stimulate protein kinase A (PKA); (2) $1 \mathrm{mM}$ cGMP to stimulate protein kinase $\mathrm{G}$ (PKG); (3) $1.3 \mathrm{mM} \mathrm{CaCl}_{2}+7 \mu \mathrm{g} / \mathrm{mL}$ phorbol myristate 
acetate to stimulate protein kinase $\mathrm{C}$ (PKC); (4) $1 \mathrm{mM}$ AMP to stimulate AMPactivated protein kinase (AMPK); or (5) $1 \mathrm{U}$ of calmodulin activity/incubation tube +1.3 $\mathrm{mM} \mathrm{CaCl}_{2}$ to stimulate calcium/calmodulin-dependent protein kinase (CaMK).

(C) Stimulation of endogenous protein phosphatases (PPase): (1) for total PPase activity: $5 \mathrm{mM} \mathrm{CaCl}_{2}+5 \mathrm{mM} \mathrm{MgCl}_{2}$; (2) for total tyrosine PPase: $25 \mathrm{mM} \mathrm{NaF}$ (inhibits Ser/Thr PPases); (3) for PP1: 2.5 nM okadaic acid (inhibits PP2A) + 2 mM EDTA + 2 mM EGTA; (4) for PP1 +PP2A: 2 mM EDTA and 2 mM EGTA; (5) for total PPase minus PP1/PP2A: $1 \mu \mathrm{M}$ okadaic acid $+5 \mathrm{mM} \mathrm{CaCl}_{2}+5 \mathrm{mM} \mathrm{MgCl}_{2}$; (6) for PP2B: $1 \mu \mathrm{M}$ okadaic acid $+5 \mathrm{mM} \mathrm{CaCl}_{2}+2 \mathrm{mM}$ EDTA; (7) for PP2C: $1 \mu \mathrm{M}$ okadaic acid $+5 \mathrm{mM}$ $\mathrm{MgCl}_{2}+2 \mathrm{mM}$ EGTA; (7) for full dephosphorylation: incubation with $1 \mathrm{U}$ calf intestinal alkaline phosphatase (AP) $+5 \mathrm{mM} \mathrm{MgCl}_{2}+5 \mathrm{mM} \mathrm{CaCl}_{2}$.

(D) Stimulation of endogenous $P K A, P K C$, and $P K G$ as a function of $\mathrm{CaCl}_{2}$ concentration: same conditions as in (B), but at concentrations of $\mathrm{CaCl}_{2}$ ranging from 0 $6.25 \mathrm{mM}$.

After incubation, all samples were desalted by low speed centrifugation through small columns of G25-Sephadex equilibrated in buffer A followed by assay under optimum conditions.

Arrhenius analysis.

Enzyme assays were performed under $\mathrm{V}_{\max }$ conditions over a temperature range from $4-68^{\circ} \mathrm{C}$. Activation energy $\left(\mathrm{E}_{\mathrm{a}}\right)$ was determined in $\mathrm{kJ} / \mathrm{mol}$ for linear portions of the relationship. 


\section{SDS gel electrophoresis and Western blotting}

Samples of frozen snail tissue were homogenized $1: 10 \mathrm{w}: \mathrm{v}$ in cold $\left(4^{\circ} \mathrm{C}\right)$ buffer that was designed to inhibit endogenous protein phosphatase, protein kinase and protease activities: $25 \mathrm{mM}$ HEPES, $\mathrm{pH} 7.0,100 \mathrm{mM}$ sucrose, $10 \%$ v:v glycerol, $0.2 \% \mathrm{w}: \mathrm{v}$ sodium deoxycholate, $2 \mathrm{mM}$ EDTA, $2 \mathrm{mM}$ EGTA, $2 \mathrm{mM} \mathrm{NaF}, 1 \mathrm{mM} \mathrm{Na}_{3} \mathrm{VO}_{4}$, and protease inhibitors added at the time of homogenization ( $1 \mu \mathrm{M}$ each of PMSF, leupeptin and aprotinin). Homogenates were centrifuged at $10,000 \mathrm{x}$ f for $10 \mathrm{~min}$ and supernatants were removed. Soluble protein concentration was determined using the Coomassie blue dye-binding method with the BioRad prepared reagent. A $250 \mu \mathrm{L}$ aliquot of supernatant was mixed 1:1 v:v with freshly prepared $2 X$ SDS-PAGE loading buffer (100 mM TrisHCl, pH. 6.8, 4\% w:v SDS, 20\% v:v glycerol, 0.2\% w:v bromophenol blue, $10 \%$ v:v 2mercaptoethanol) and boiled for 5 minutes. Samples were immediately cold-snapped and stored at $-20^{\circ} \mathrm{C}$. Aliquots containing $15 \mu \mathrm{g}$ of soluble protein were loaded onto SDSpolyacrylamide gels (10\% resolving gel, $5 \%$ stacking gel). Samples were electrophoresed at $200 \mathrm{~V}$ for $\sim 1 \mathrm{~h}$ until the dye front reached the bottom of the gel in $1 \mathrm{X}$ running buffer (5X buffer contains $15.1 \mathrm{~g}$ Tris-base, $94 \mathrm{~g}$ glycine, $5 \mathrm{~g}$ SDS per litre, $\mathrm{pH} 8.0$ ).

Proteins were wet-transferred to PVDF membrane $\left(300 \mathrm{~mA}\right.$ for $3 \mathrm{~h}$ at $\left.4^{\circ} \mathrm{C}\right)$ using the Bio-Rad Mini Trans-Blot Cell apparatus. The transfer buffer contained $25 \mathrm{mM}$ Trisbase ( $\mathrm{pH} 8.8$ ), $192 \mathrm{mM}$ glycine, and $20 \% \mathrm{v}: \mathrm{v}$ methanol, chilled to $4^{\circ} \mathrm{C}$. Membranes were then blocked with $1 \%$ non-fat dried milk in Tris-buffered saline containing Tween-20 (TBST: $10 \mathrm{mM}$ Tris-base, $\mathrm{pH} 7.0,150 \mathrm{mM} \mathrm{NaCl}, 0.1 \%$ or v:v Tween 20 ) for $1 \mathrm{~h}$ at $4^{\circ} \mathrm{C}$. Membranes were incubated overnight at $4^{\circ} \mathrm{C}$ with $\alpha 5-\mathrm{Na}^{+} \mathrm{K}^{+}$-ATPase primary antibody (mouse anti-chicken IgG serum antibody) diluted 1:1000 v:v in TBST. After $3 \times 5 \mathrm{~min}$ 
washes with TBST, membranes were then incubated with HRP-conjugated goat antimouse secondary antibody (diluted 1:2000 in TBST) for 2-3 $\mathrm{h}$ at room temperature, followed by 3 x 5 min washes in TBST. Proteins were visualized using Western Lightning Chemiluminescence Plus reagents (Perkin Elmer, Boston, MA) following manufacturer's protocols and the ECL signal was detected using the ChemiGenius bioimaging system (Syngene, Frederick, MD) after exposures of 5 min (foot muscle) or 15 min (hepatopancreas) and quantified using Syngene GeneTools software (v3.00.02). Subsequently, the blot was stained with Coomassie blue $(0.25 \%$ w:v Coomassie Blue, $50 \% \mathrm{v}: \mathrm{v}$ methanol, $7.5 \% \mathrm{v}: \mathrm{v}$ acetic acid) for $1 \mathrm{~h}$ and destained overnight with $25 \% \mathrm{v}: \mathrm{v}$ methanol, $10 \% \mathrm{v}: \mathrm{v}$ acetic acid. The scanned intensities of three Coomassie stained bands that did not change between active and estivating conditions were used to normalize the corresponding intensity of the immuno-reacting band in each lane to correct for any unequal protein loading. BioRad Kaleidoscope pre-stained markers were run in one lane of each gel to assess the subunit molecular mass of the test protein.

\section{Pulse proteolysis of $\mathrm{Na}^{+} \mathrm{K}^{+}$-ATPase}

To assess changes in the structural stability of $\mathrm{Na}^{+} \mathrm{K}^{+}$-ATPase between active and estivating snails, the enzyme was subjected to urea-dependent denaturation and subsequent thermolysin-mediated proteolysis, methods adapted from Park and Marqusee (2005). Tissue extracts were homogenized in buffer B (buffer A plus $0.2 \%$ w:v sodium deoxycholate, $2 \mathrm{mM}$ EDTA, $2 \mathrm{mM}$ EGTA and $25 \mathrm{mM} \mathrm{NaF}$ but without the addition of PMSF), centrifuged, and $50 \mu \mathrm{L}$ aliquots of supernatant were incubated with $100 \mu \mathrm{L}$ of a urea solution made up in buffer B. After $12 \mathrm{~h}$ incubation at room temperature, extracts 
were treated with $10 \mu \mathrm{L}$ of $10 \mathrm{~g} / \mathrm{L}$ thermolysin (Sigma; stock prepared with $2.5 \mathrm{M}$

$\mathrm{NaCl}$ and $10 \mathrm{mM} \mathrm{CaCl}_{2}$ ). Thermolysin activity was halted after $10 \mathrm{~min}$ by the addition of $20 \mu \mathrm{L}$ of $50 \mathrm{mM}$ EDTA ( $\mathrm{pH} 8.0$ ). The amount of enzyme protein remaining after protease treatment was assessed by Western blotting and enzyme activity was assayed as a function of urea concentration. Parameters of protein unfolding $\left(\mathrm{C}_{\mathrm{m}}\right)$ and activity inhibition $\left(\mathrm{I}_{50}\right.$ ) by urea were calculated as described above for $\mathrm{Na}^{+} \mathrm{K}^{+}$-ATPase assay.

\section{Results}

\section{Optimization of experimental conditions}

Initial trials were used to optimize the amount of $\mathrm{Na}^{+} \mathrm{K}^{+}$-ATPase activity that could be recovered from $O$. lactea hepatopancreas and foot muscle. Inclusion of $2 \mathrm{mM}$ EDTA, $2 \mathrm{mM}$ EGTA (to inhibit protein kinases) and $25 \mathrm{mM} \mathrm{NaF}$ (to inhibit protein phosphatases) in the homogenization buffer did not significantly alter recoverable $\mathrm{Na}^{+} \mathrm{K}^{+}$ATPase activity but inclusion of B-glycerophosphate or sodium vanadate strongly reduced recoverable activity. Therefore, the standard preparation of tissue extracts included EDTA/EGTA/NaF. Addition of detergents (deoxycholate, Brij-35, CHAPS) was also tested; $0.2 \% \mathrm{w}: \mathrm{v}$ deoxycholate increased recoverable activity and was also included in standard preparations. Figure 2.1 shows the effect of $\mathrm{pH}$ on $\mathrm{Na}^{+} \mathrm{K}^{+}$-ATPase activity in hepatopancreas. The $\mathrm{pH}$ optimum for the enzyme from active snails was 7.4 but the optimum decreased to $\mathrm{pH}$ 6.8-7.0 for the enzyme isolated from $10 \mathrm{~d}$ estivating snails. Foot muscle enzyme behaved similarly (data not shown) with pH optima of 7.2 and 7.0 for the enzyme from active and estivated snails, respectively. Other trials optimized substrate and ion concentrations $(20 \mathrm{mM} \mathrm{KCl}, 100 \mathrm{mM} \mathrm{NaCl}, 5 \mathrm{mM} \mathrm{MgCl}$, and $5 \mathrm{mM}$ 
$\mathrm{Mg}^{2+}$-ATP), volume of enzyme extract used ( $25 \mu \mathrm{L}$ added to $225 \mu \mathrm{L}$ assay mixture for $250 \mu \mathrm{L}$ final volume), reaction time (10 $\mathrm{min})$, and time for colour development (10 $\mathrm{min})$, validating that the assays were linear with respect to assay time and amount of enzyme used.

\section{Determination of kinetic constants}

The kinetic properties of $\mathrm{Na}^{+} \mathrm{K}^{+}$-ATPase from both foot muscle and hepatopancreas were characterized in extracts from active and estivating snails. Table 2.1 shows that the maximal velocity of the enzyme was reduced significantly during estivation to $67 \%$ and $65 \%$ of the activity in foot muscle and hepatopancreas of active snails, respectively. $\mathrm{Na}^{+} \mathrm{K}^{+}$-ATPase activity displayed sigmoidal kinetics with respect to ATP in both tissues (Figure 2.2), with Hill coefficients of 1.6-2.7 for the foot enzyme and 1.7-2.2 for hepatopancreas. Generally, kinetic data were consistent with the presence of a less active form of the enzyme in the estivated state. Thus, enzyme affinity for ATP was reduced during estivation; the $S_{0.5}$ ATP increased by 1.4-fold in estivation for both foot muscle and hepatopancreas $\mathrm{Na}^{+} \mathrm{K}^{+}$-ATPase, compared with the enzyme from active snails. Similarly, foot muscle from estivated snails showed a 1.8-fold increase in $\mathrm{K}_{\mathrm{m}} \mathrm{Na}^{+}$ and a 1.6-fold increase in $\mathrm{K}_{\mathrm{a}} \mathrm{Mg}^{2+}$ as compared with the enzyme from active snails. In hepatopancreas, the $\mathrm{I}_{50} \mathrm{~K}^{+}$was 1.7 -fold higher in estivating versus active snails.

$\mathrm{Na}^{+} \mathrm{K}^{+}$-ATPase affinity for ATP was also studied as a function of temperature (Figure 2.3). Affinity for ATP generally increased ( $\mathrm{S}_{0.5}$ decreased) with increasing temperature for the enzyme from active snails, with highest affinity at $30^{\circ} \mathrm{C}$. However, the enzyme from estivated snails did not show a significant change in affinity for ATP 
with temperature. In both tissues the enzyme from estivated snails had significantly higher $\mathrm{S}_{0.5}$ ATP values at each of the higher assay temperatures $\left(22^{\circ} \mathrm{C}, 30^{\circ} \mathrm{C}, 40^{\circ} \mathrm{C}\right)$, as compared with the corresponding values for active snails (Student's t-test, $\mathrm{P}<0.01$ ).

\section{In vitro incubations to stimulate endogenous kinase and phosphatase action on $\mathrm{Na}^{+} \mathrm{K}^{+}$-}

\section{ATPase}

The significant differences in kinetic properties of $\mathrm{Na}^{+} \mathrm{K}^{+}$-ATPase between active and estivated states could be due to an estivation-mediated covalent modification of the enzyme, predictably as a result of reversible protein phosphorylation. To test this, the enzyme was incubated in vitro under conditions that stimulated the activities of endogenous protein kinases or protein phosphatases. The effects of these incubations on $\mathrm{Na}^{+} \mathrm{K}^{+}$-ATPase in foot muscle extracts from active and estivated snails are shown in Figure 2.4. Incubation of foot muscle $\mathrm{Na}^{+} \mathrm{K}^{+}$-ATPase from active snails under conditions that stimulated protein kinases $A, C$ or $G$ resulted in significant decreases in enzyme $V_{\max }$ activity to values that were $51 \%, 42 \%$, and $46 \%$ of the corresponding value in control incubations (Figure 2.4A). By contrast, conditions that stimulated AMPK or CaMK did not alter $\mathrm{Na}^{+} \mathrm{K}^{+}$-ATPase activity. The same pattern of results was seen when extracts of estivated foot muscle were incubated; $\mathrm{Na}^{+} \mathrm{K}^{+}$-ATPase activity was reduced to $61 \%, 67 \%$, and $65 \%$ of the corresponding value in control incubations by stimulation of PKA, PKC, and PKG, respectively. Figure 2.4B shows the effects of incubations that promoted the activity of endogenous phosphatases. In no case did stimulation of phosphatases have an effect on $\mathrm{Na}^{+} \mathrm{K}^{+}$-ATPase activity from active snails. However, stimulation of phosphatases elevated the activity of foot $\mathrm{Na}^{+} \mathrm{K}^{+}$-ATPase from estivated snails under 
conditions that (a) stimulated total phosphatase activity, (b) stimulated PP1-type activity, or (c) stimulated PP1/PP2A-type activity. In each of these cases, $\mathrm{Na}^{+} \mathrm{K}^{+}$-ATPase activity increased by $\sim 1.7$-fold over activity in control incubations. Similarly, incubation with calf intestinal alkaline phosphatase (AP) also increased activity, by 1.8 -fold as compared with the control incubation.

Similar results were seen in incubation studies with hepatopancreas extracts from active and $10 \mathrm{~d}$ estivated snails (Figure 2.5). Stimulation of endogenous protein kinases decreased $\mathrm{Na}^{+} \mathrm{K}^{+}$-ATPase maximal activity in three out of five cases. Stimulation of PKA, PKC, and PKG decreased activity to $41 \%, 42 \%$, and $45 \%$ of the $\mathrm{Na}^{+} \mathrm{K}^{+}$-ATPase activity seen in control incubations whereas stimulation of AMPK or CaMK again had no effect (Figure 2.5A). However, unlike the situation with foot muscle extracts, in vitro incubation of hepatopancreas extracts from estivated snails under conditions that stimulated protein kinases did not alter enzyme activity. Incubations promoting endogenous phosphatase activity again had no effect on $\mathrm{Na}^{+} \mathrm{K}^{+}$-ATPase $\mathrm{V}_{\max }$ in extracts from active snails (Figure 2.5B). However, stimulation of several classes of phosphatases significantly increased $\mathrm{Na}^{+} \mathrm{K}^{+}$-ATPase activity in extracts from estivated snails. This included stimulation of (a) total phosphatase activity, (b) PP1-type activity, (c) PP1/PP2A-type activity, and (d) total phosphatase activity minus PP1/PP2A-type activity all of which produced $\sim 1.8$-fold increases in $\mathrm{Na}^{+} \mathrm{K}^{+}$-ATPase activity. Furthermore, stimulation of PP2C-type activity and incubation with AP led to 1.4-fold and 1.7-fold increases in activity, respectively, for $\mathrm{Na}^{+} \mathrm{K}^{+}$-ATPase from estivated snails.

In mammalian systems PKA- and PKC-mediated phosphorylation can either stimulate or inhibit $\mathrm{Na}^{+} \mathrm{K}^{+}$-ATPase activity, often dependent on calcium concentration 
(Cheng et al., 1999). To determine if calcium influenced the effect of phosphorylation on snail $\mathrm{Na}^{+} \mathrm{K}^{+}$-ATPase, extracts from active snails were incubated under conditions that stimulated PKA, PKC or PKG in the presence of different concentrations of calcium. The presence of $\mathrm{Ca}^{2+}$ had no effect on PKA-or PKG-mediated inhibition of snail $\mathrm{Na}^{+} \mathrm{K}^{+}-$ ATPase activity (Figure 2.6). In the absence of $\mathrm{Ca}^{2+}$, there was no PKC effect on enzyme activity but all three concentrations $(0.25,1.25$, and $6.25 \mathrm{mM}) \mathrm{Ca}^{2+}$ tested produced similar PKC-mediated inhibition of enzyme activity. Similar results were also seen in hepatopancreas extracts from active snails (not shown).

\section{Arrhenius plots}

The effects of temperature on $\mathrm{Na}^{+} \mathrm{K}^{+}$-ATPase activity are shown as Arrhenius plots in Figure 2.7 for both the foot muscle (A) and hepatopancreas (B) enzymes. The plots were linear between $4-33^{\circ} \mathrm{C}$ in both cases. However, activity did not continue to increase at higher temperatures, suggesting that high temperature degradation was occurring. Activation energies calculated from the linear parts of the relationship revealed 1.5-fold higher activation energy for the enzyme from estivated snails, compared with active snails, in both tissues (Table 2.1).

\section{$\mathrm{Na}^{+} / \mathrm{K}^{+}$-ATPase protein content}

To determine if the change in $\mathrm{Na}^{+} \mathrm{K}^{+}$-ATPase activity seen during estivation was associated with a change in the amount of $\mathrm{Na}^{+} \mathrm{K}^{+}$-ATPase protein in tissues, Western blotting was used with polyclonal antibodies raised against the alpha subunit of $\mathrm{Na}^{+} \mathrm{K}^{+}-$ ATPase. The mouse anti-chicken $\mathrm{Na}^{+} \mathrm{K}^{+}$-ATPase antibody recognized a $\sim 100 \mathrm{kDa}$ band 
in both tissues, consistent with the known size of the alpha subunit. Figure 2.8 shows that the amount of $\mathrm{Na}^{+} \mathrm{K}^{+}$-ATPase protein did not change between active and estivated states in either tissue.

\section{$N a^{+} / K^{+}-A T P a s e$ protein stability}

To determine if there are differences in the structural stability of snail $\mathrm{Na}^{+} / \mathrm{K}^{+}$ATPase between active and estivating states, the technique of pulse proteolysis was used. Following incubation of the enzyme with multiple concentrations of urea to achieve different degrees of protein unfolding, the enzyme was given a short pulse of proteolysis with thermolysin and then the amount of protein remaining was measured by Western blotting. The results revealed that there was no significant difference in resistance of $\mathrm{Na}^{+} \mathrm{K}^{+}$-ATPase to unfolding/denaturation by urea between active and estivating states in either foot muscle (Figure 2.9) or hepatopancreas (not shown). The $C_{m}$ value (the amount of urea required to unfold $50 \%$ of the protein, rendering it susceptible to thermolysin proteolysis) did not change between active and estivating states in either tissue (Figure 2.9a, Table 2.1). However, the $\mathrm{I}_{50}$ value (the amount of urea required to inhibit enzyme activity by $50 \%$ ) was 1.3 -fold higher for $\mathrm{Na}^{+} \mathrm{K}^{+}$-ATPase from foot muscle of estivating snails (Figure $2.9 \mathrm{~b}$, Table 2.1). Inhibition of hepatopancreas $\mathrm{Na}^{+} \mathrm{K}^{+}$-ATPase by urea was similar between active and estivating states (Table 2.1). 
Table 2.1. Kinetic parameters for $\mathrm{Na}^{+} / \mathrm{K}^{+}$-ATPase from foot muscle and hepatopancreas of active and $10 \mathrm{~d}$ estivated $O$. lactea.

\begin{tabular}{lllll}
\hline & Foot muscle & & Hepatopancreas \\
& Active & Estivated & Active & Estivated \\
\hline $\mathrm{V}_{\max }\left(\mathrm{mU}\right.$ mg soluble protein $\left.{ }^{-1}\right)$ & $31.0 \pm 1.6$ & $20.4 \pm 1.6^{*}$ & $18.0 \pm 1.2$ & $11.7 \pm 1.0^{*}$ \\
$\mathrm{~S}_{0.5} \mathrm{Mg} . \mathrm{ATP}(\mathrm{mM})$ & $0.75 \pm 0.05$ & $1.07 \pm 0.06^{*}$ & $0.90 \pm 0.11$ & $1.24 \pm 0.07^{*}$ \\
$\mathrm{~K}_{\mathrm{m}} \mathrm{Na}^{+}(\mathrm{mM})$ & $38 \pm 4$ & $67 \pm 7^{*}$ & $34 \pm 5$ & $42 \pm 9$ \\
$\mathrm{~K}_{\mathrm{m}} \mathrm{K}^{+}(\mathrm{mM})$ & $11 \pm 2$ & $16 \pm 3$ & $14 \pm 4$ & $16 \pm 2$ \\
$\mathrm{~K}_{\mathrm{a}} \mathrm{Mg}^{2+}(\mathrm{mM})$ & $1.7 \pm 0.3$ & $2.7 \pm 0.3^{*}$ & $1.6 \pm 0.3$ & $2.4 \pm 0.5$ \\
$\mathrm{I}_{50} \mathrm{Na}^{+}(\mathrm{mM})$ & $258 \pm 33$ & $325 \pm 57$ & $194 \pm 21$ & $207 \pm 20$ \\
$\mathrm{I}_{50} \mathrm{~K}^{+}(\mathrm{mM})$ & $82 \pm 11$ & $167 \pm 32$ & $65 \pm 9$ & $109 \pm 13^{*}$ \\
$\mathrm{I}_{50} \mathrm{Mg}^{2+}(\mathrm{mM})$ & $32 \pm 5$ & $45 \pm 11$ & $48 \pm 8$ & $42 \pm 8$ \\
$\mathrm{I}_{50} \mathrm{Urea}(\mathrm{mM})$ & $3.3 \pm 0.4$ & $4.4 \pm 0.4^{*}$ & $4.1 \pm 0.4$ & $3.7 \pm 0.5$ \\
$\mathrm{C}_{\mathrm{m}} \mathrm{Urea}(\mathrm{mM})$ & $3.9 \pm 0.5$ & $3.9 \pm 0.4$ & $3.9 \pm 0.6$ & $3.4 \pm 0.7$ \\
$\mathrm{E}_{\mathrm{a}}(\mathrm{kJ} / \mathrm{mol})$ & $18.6 \pm 2.9$ & $27.1 \pm 3.1^{*}$ & $22.2 \pm 3.5$ & $31.9 \pm 3.1^{*}$ \\
\hline $\mathrm{As}$ & & & &
\end{tabular}

Assays were conducted at $22^{\circ} \mathrm{C}$ (except for Arrhenius plots) at optimum conditions. Data are means \pm S.E.M. $(n=4)$, except for $n=9$ for foot muscle $V_{\max }$ and $K_{m}\left(M^{2+}-A T P\right)$ and $\mathrm{n}=3$ for $\mathrm{I}_{50}$ (Urea) and $\mathrm{C}_{\mathrm{m}}$ (Urea). $\mathrm{S}_{0.5}$ and $\mathrm{K}_{\mathrm{m}}$ are substrate concentrations that produce half-maximal velocity for sigmoidal versus hyperbolic relationships, respectively. $K_{a}$ is the activator concentration that produces half-maximal activation, $I_{50}$ is the concentration of inhibitor that reduces enzyme activity by $50 \%$, and $\mathrm{C}_{\mathrm{m}}$ is the denaturant concentration required to unfold $50 \%$ of the protein. $\mathrm{E}_{\mathrm{a}}$ is the activation energy calculated from Arrhenius plots. *- Significantly different from the corresponding value for active snails, $\mathrm{P}<0.05$. 
Figure 2.1. $\mathrm{Na}^{+} \mathrm{K}^{+}$-ATPase activity in hepatopancreas from active and estivated $O$. lactea as a function of assay $\mathrm{pH}$. Assays were conducted under optimal substrate concentrations at $22^{\circ}$ C. Data are means \pm S.E.M., $n=4$ independent preparations of enzyme. 


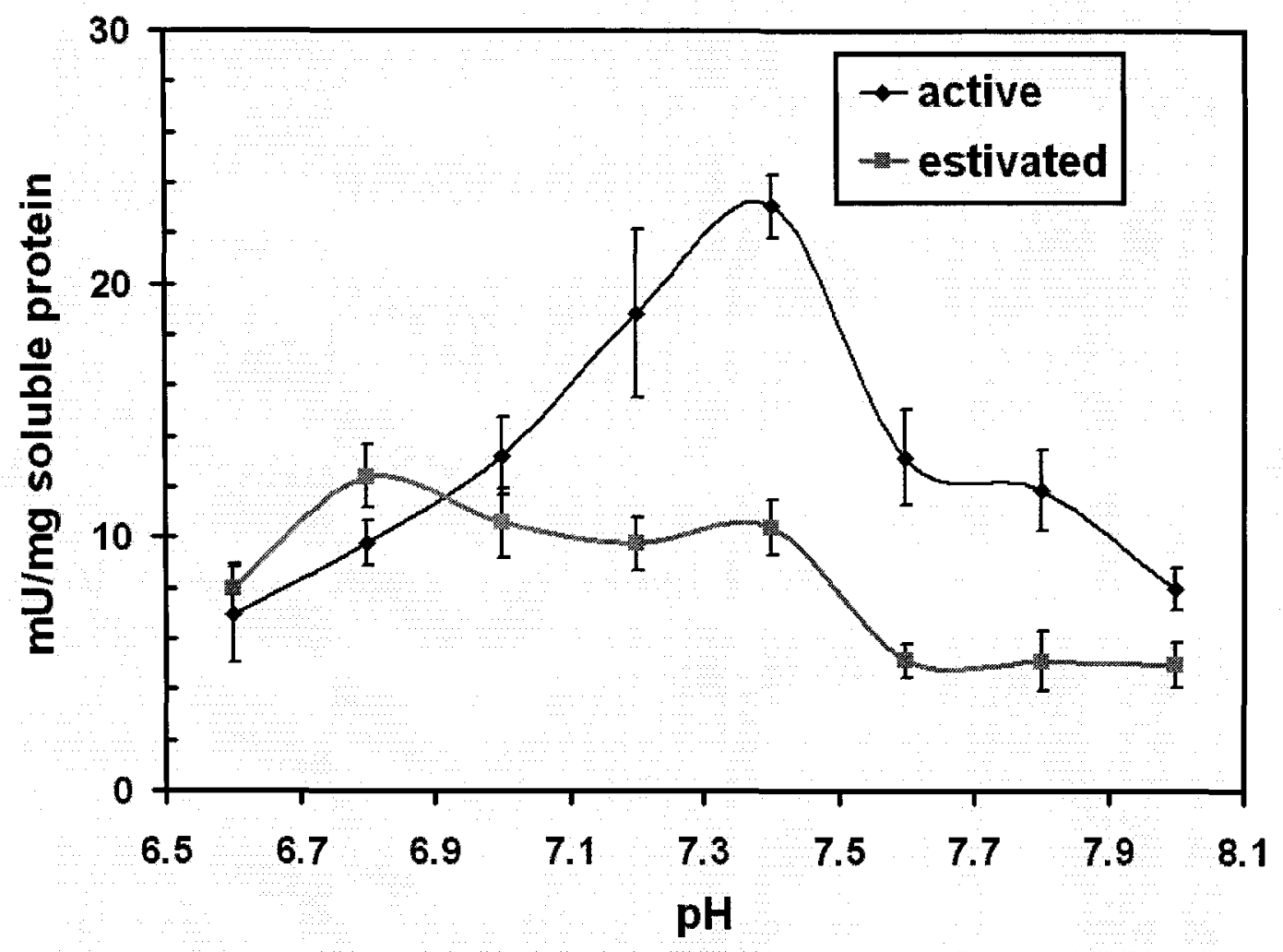


Figure 2.2. $\mathrm{Na}^{+} \mathrm{K}^{+}$-ATPase activity in O. lactea (A) foot muscle (mean \pm S.E.M, $\mathrm{n}=9$ ) and (B) hepatopancreas (mean \pm S.E.M., $n=4$ ) as a function of ATP concentration. 

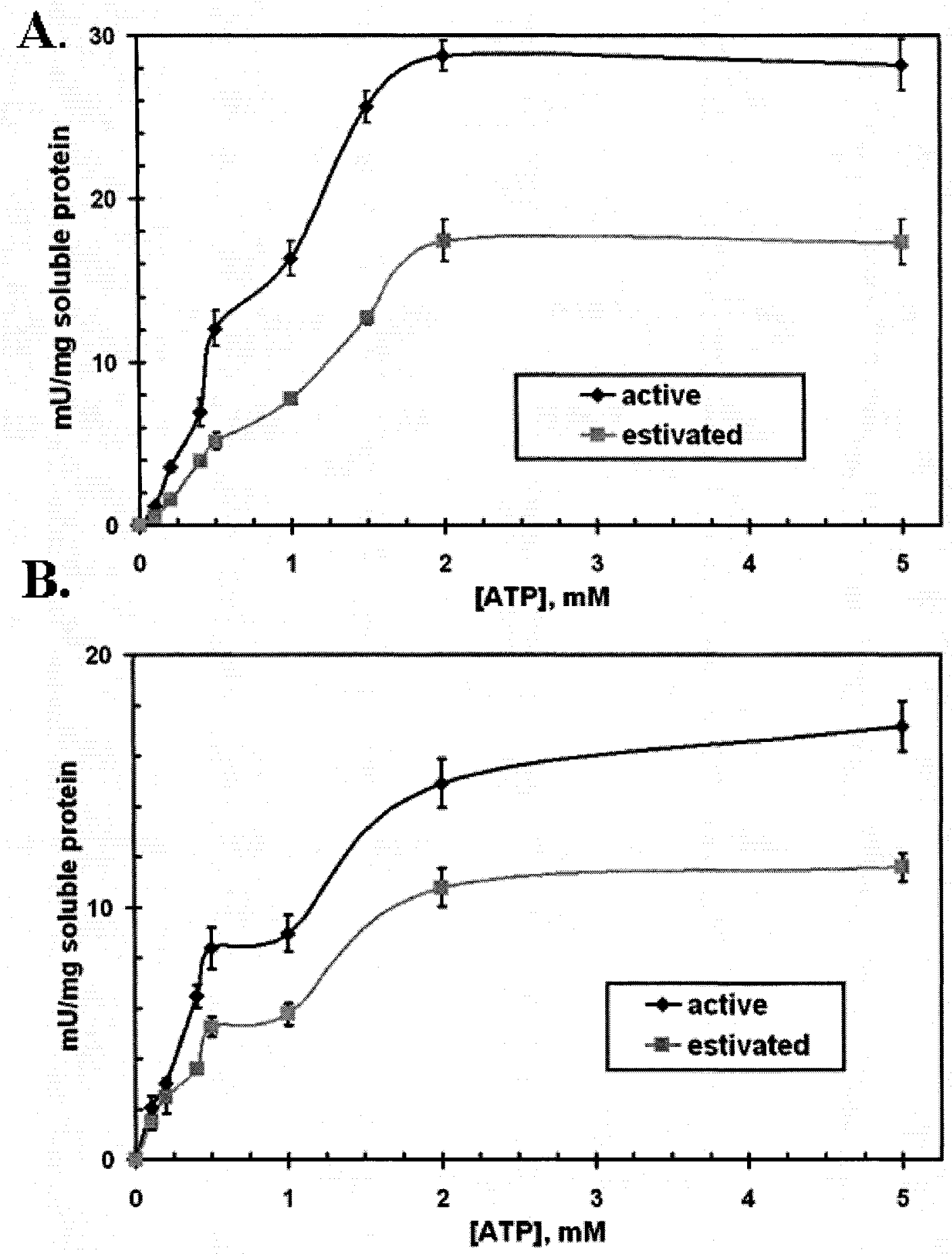
Figure 2.3. Substrate affinity for ATP as a function of temperature for $\mathrm{Na}^{+} \mathrm{K}^{+}$-ATPase activity in $O$. lactea (A) foot muscle and (B) hepatopancreas. Data are means \pm S.E.M., $\mathrm{n}=4$ independent preparations of enzyme except for foot muscle active and estivated activities at $22^{\circ} \mathrm{C}$, which are $\mathrm{n}=9$. a - Significantly different from the corresponding control incubation using the Student's t-test, $\mathrm{P}<0.01$. 

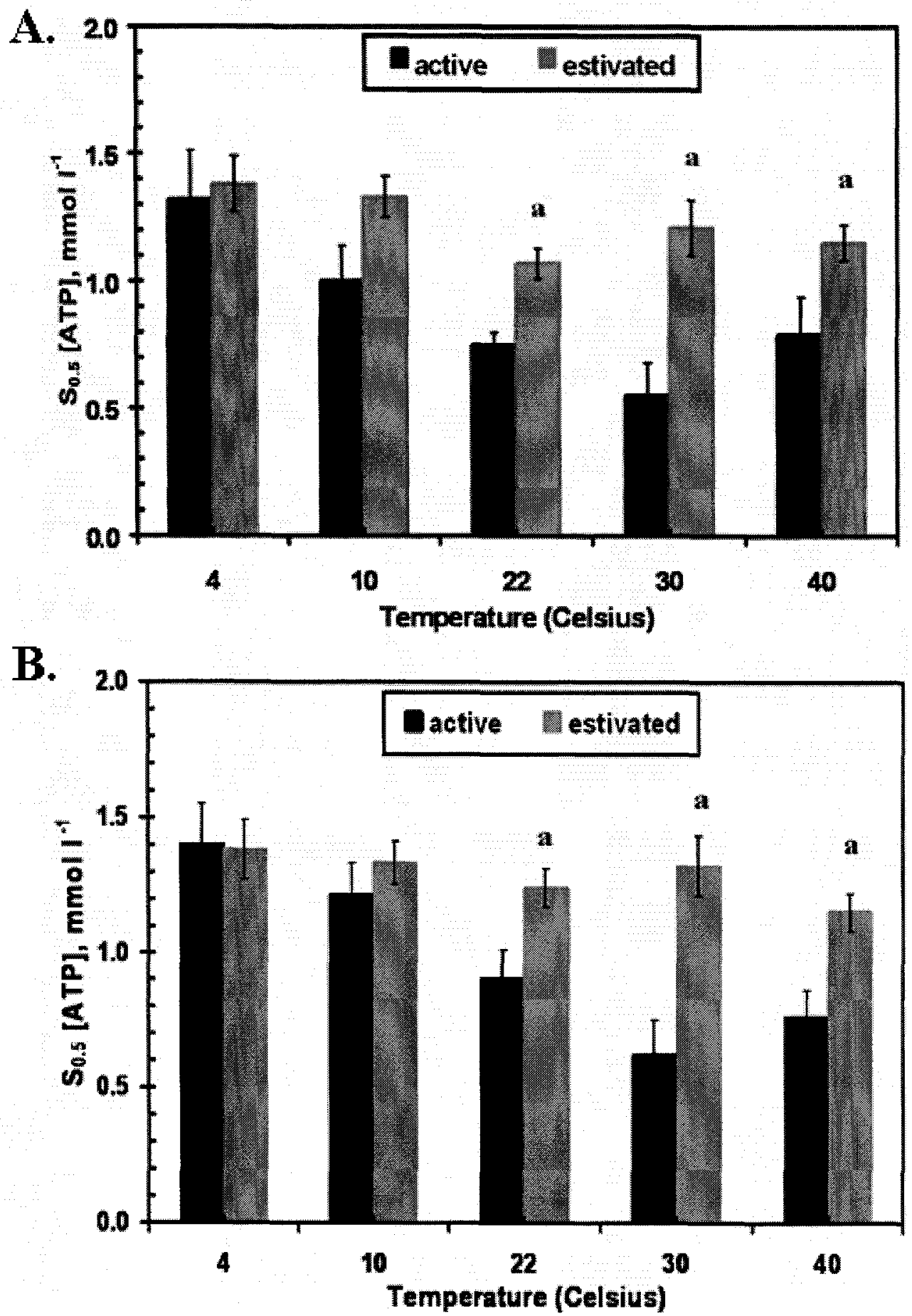
Figure 2.4. Effect of in vitro incubations to stimulate the activities of endogenous (A) protein kinases and (B) protein phosphatases on $\mathrm{Na}^{+} \mathrm{K}^{+}$-ATPase activity in foot muscle extracts from active and $10 \mathrm{~d}$ estivated $O$. lactea. Incubation time was $4 \mathrm{~h}$ under conditions as described in Materials and Methods followed by assay under $V_{\max }$ conditions at $22^{\circ}$ C. CTR- control incubations. Data are means \pm S.E.M, $n=4$ independent determinations. a - Significantly different from the corresponding control incubation using the Student's t-test, $\mathrm{P}<0.01 ; \mathrm{b}-\mathrm{P}<0.05$. 

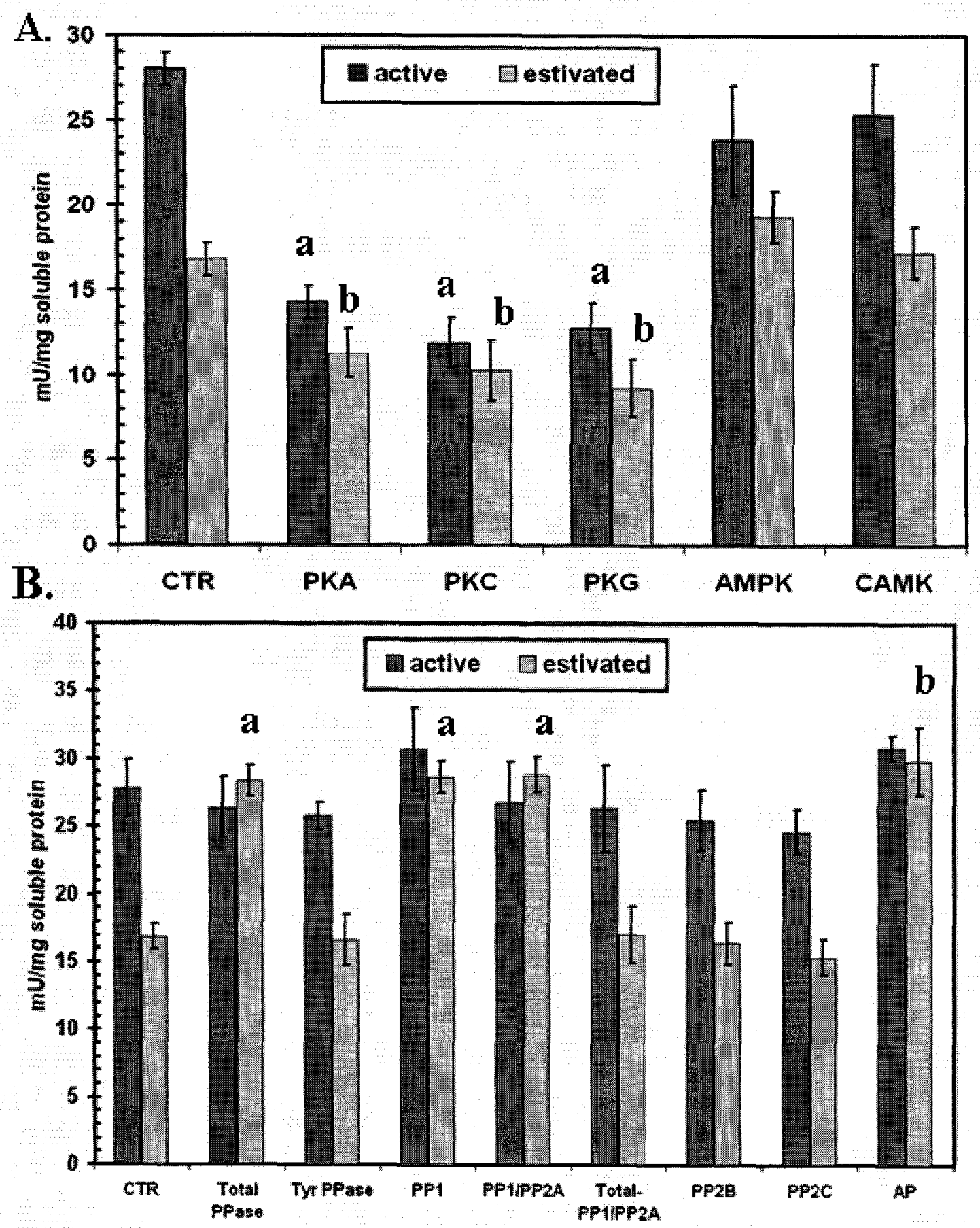
Figure 2.5. Effect of in vitro incubations stimulating the activities of endogenous (A) protein kinases and (B) protein phosphatases on $\mathrm{Na}^{+} \mathrm{K}^{+}$-ATPase activity in hepatopancreas extracts from active and $10 \mathrm{~d}$ estivated $O$. lactea. Other information as in Figure 2.4. 

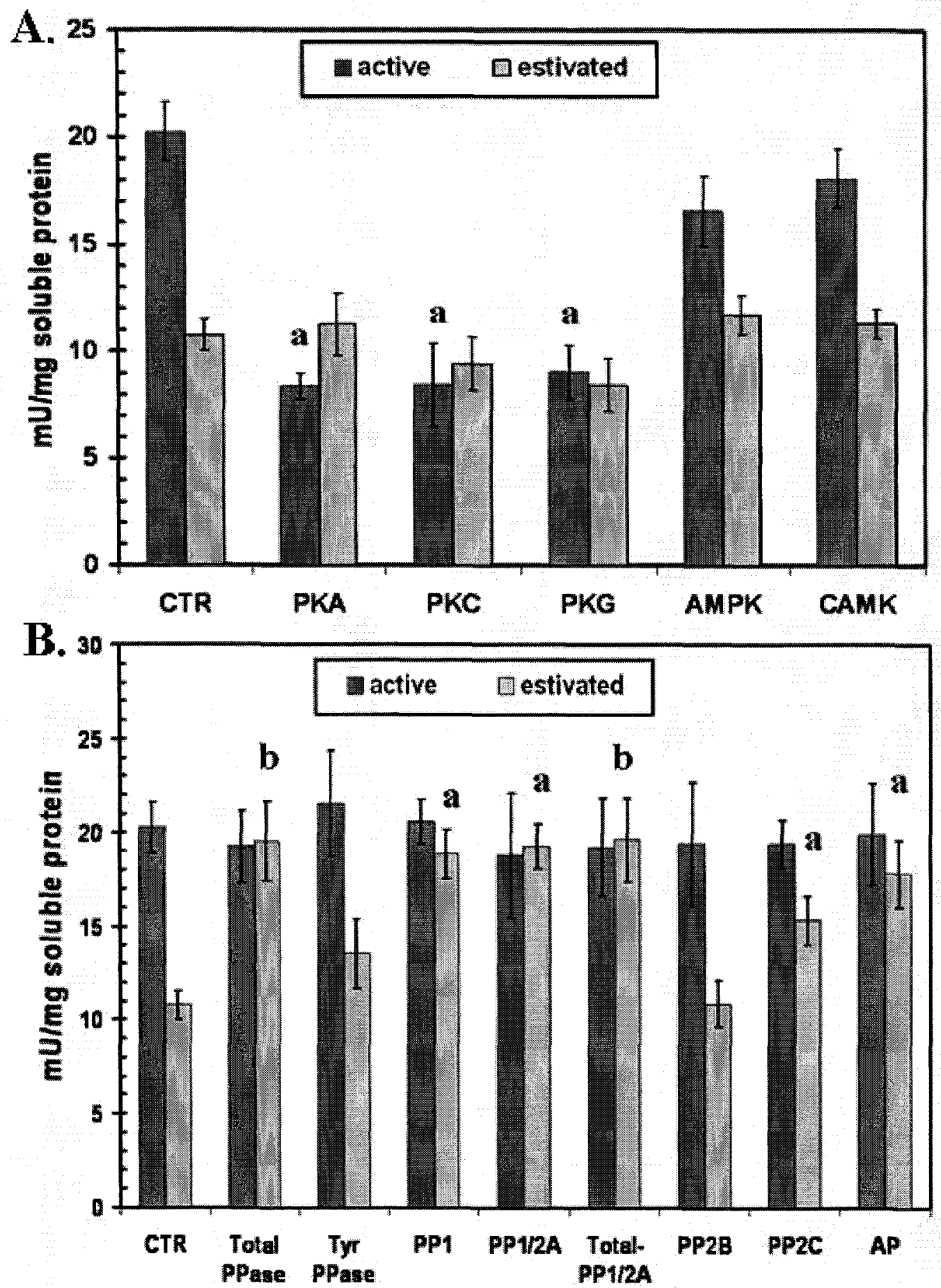
Figure 2.6. Effect of calcium concentration on the stimulation by endogenous protein kinases of $\mathrm{Na}^{+} \mathrm{K}^{+}$-ATPase activity in foot muscle extracts from active snails. In vitro incubations stimulated PKA, PKC or PKG and the resulting change in $\mathrm{Na}^{+} \mathrm{K}^{+}$-ATPase activity is expressed as a percentage of the activity in control incubations where protein kinases were not stimulated. Other information as in Figure 2.4. a - Significantly different from the corresponding incubation with zero calcium concentration using the Student's ttest, $\mathrm{P}<0.01$. 


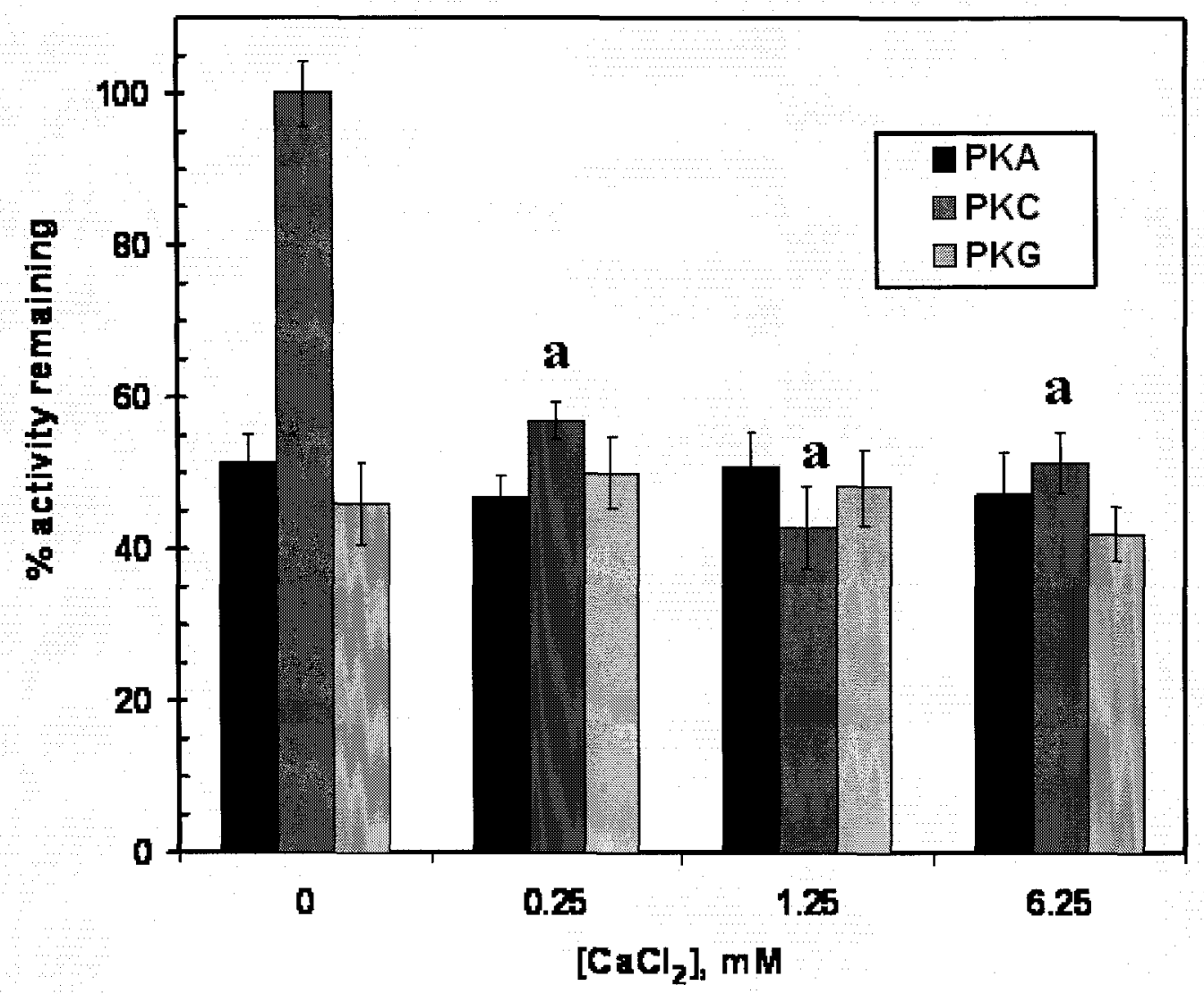


Figure 2.7. Arrhenius plots showing $\mathrm{Na}^{+} \mathrm{K}^{+}$-ATPase maximal activity as a function of temperature (Kelvin) for (A) foot muscle and (B) hepatopancreas from O. lactea. Data are means \pm S.E.M, $n=4$ independent preparations of enzyme. Assay mixtures were preincubated for 5 minutes in water baths set to specified temperatures prior to initiating reactions by the addition of ATP. Assays were conducted at maximum substrate concentrations. Arrhenius activation energy $\left(\mathrm{E}_{\mathrm{A}}\right)$ was calculated from the linear part of the relationship. 
A.

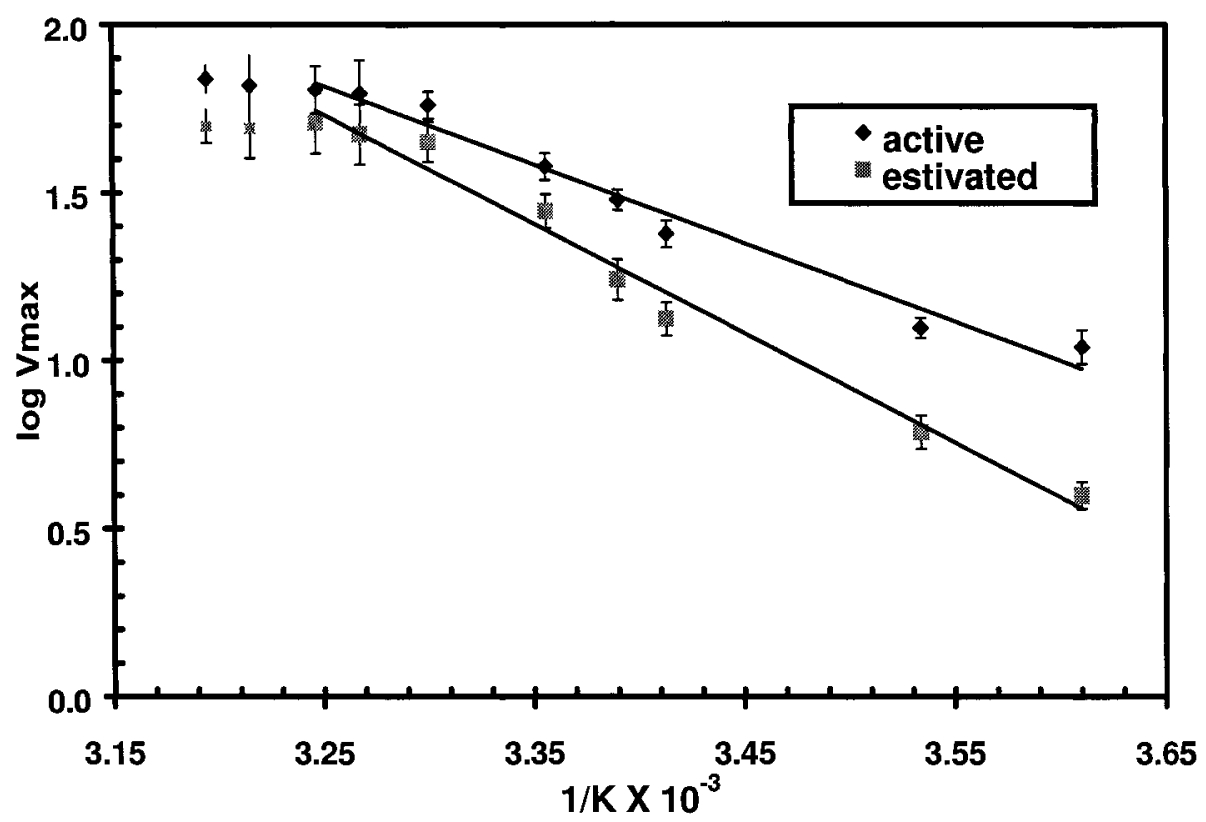

B.

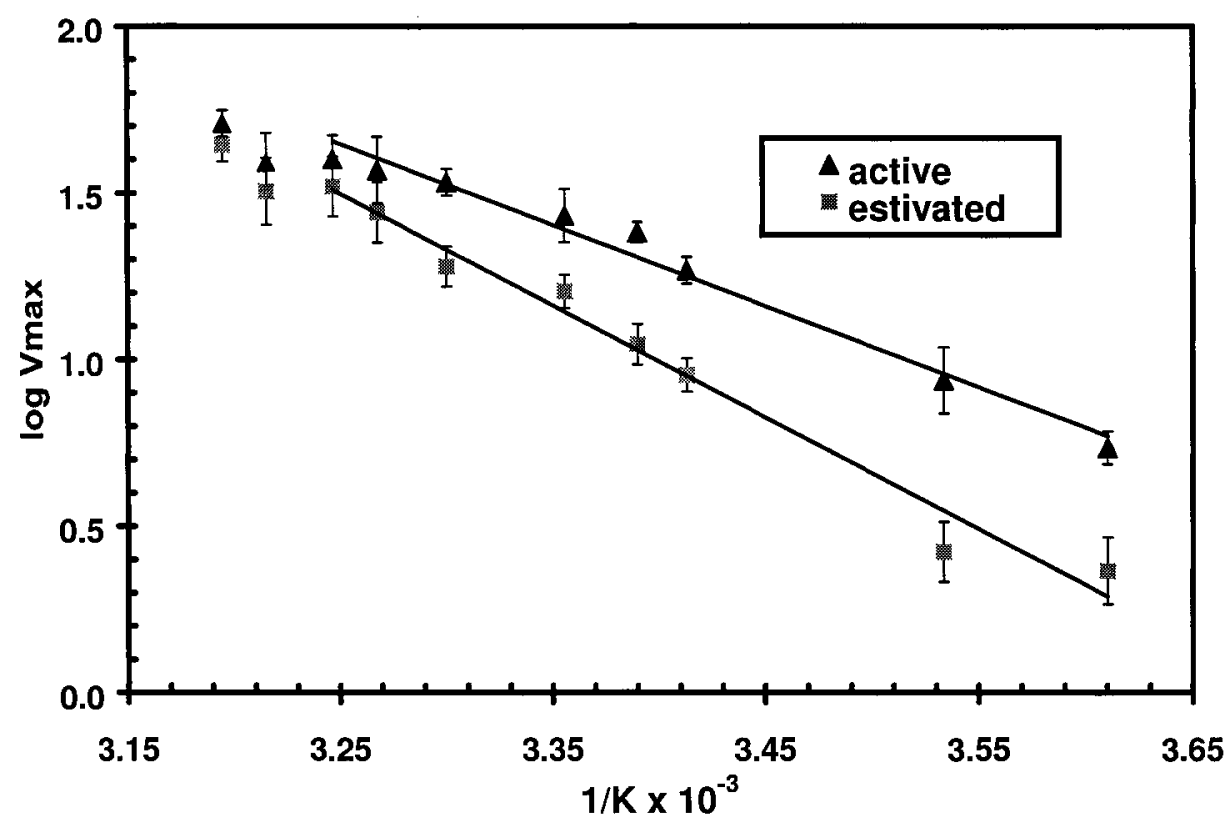


Figure 2.8. Western blots showing $\mathrm{Na}^{+} \mathrm{K}^{+}$-ATPase protein content in (A) foot muscle and (B) hepatopancreas of active and $10 \mathrm{~d}$ estivated snails. Representative blots are shown for four independent samples. Band densities were normalized against the combined measured densities of three strong Coomassie stained protein bands that did not change between control and estivated states and histograms show the mean normalized band densities ( \pm S.E.M, $n=10$ for foot muscle, $n=8$ for hepatopancreas). The band shown corresponds to $\sim 100 \mathrm{kDa}$, as determined by from a standard curve developed using Kaleidoscope protein size markers, and is consistent with the expected size of the alpha subunit of $\mathrm{Na}^{+} \mathrm{K}^{+}$-ATPase. 


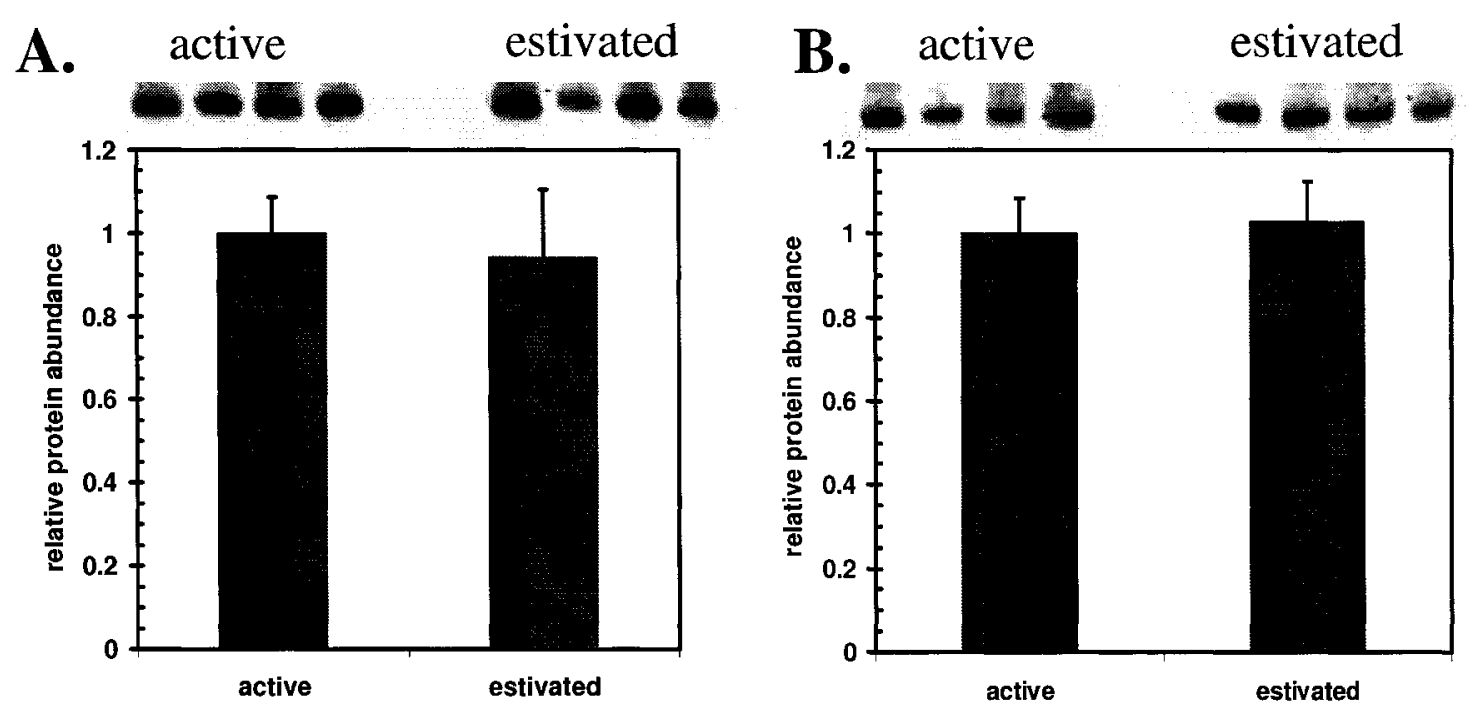


Figure 2.9. Structural unfolding and enzymatic inhibition by urea of foot muscle $\mathrm{Na}^{+} \mathrm{K}^{+}-$ ATPase from active and estivating snails. Enzyme extracts were denatured overnight with different concentrations of urea and then either treated with thermolysin or assayed under optimal conditions. (A) Mean relative $\mathrm{Na}^{+} \mathrm{K}^{+}$-ATPase protein remaining (as quantified from band intensities on Western blots) after overnight incubation with urea and subsequent proteolysis with thermolysin; data are means \pm S.E.M, $n=3$ independent trials. (B) Mean relative activity of foot muscle $\mathrm{Na}^{+} \mathrm{K}^{+}$-ATPase from active and estivating snails as a function of overnight incubation with different concentrations of urea; data are means \pm S.E.M, $n=3$. 


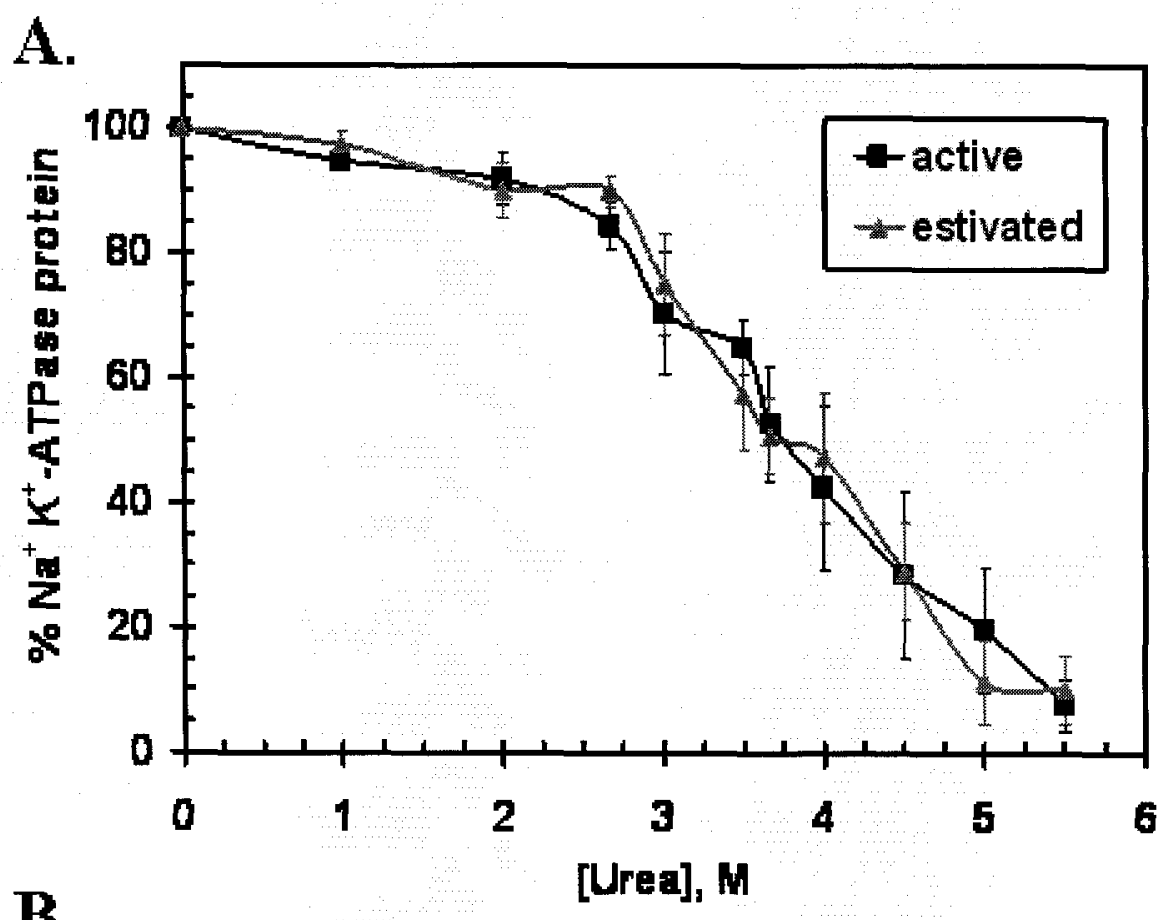

B.

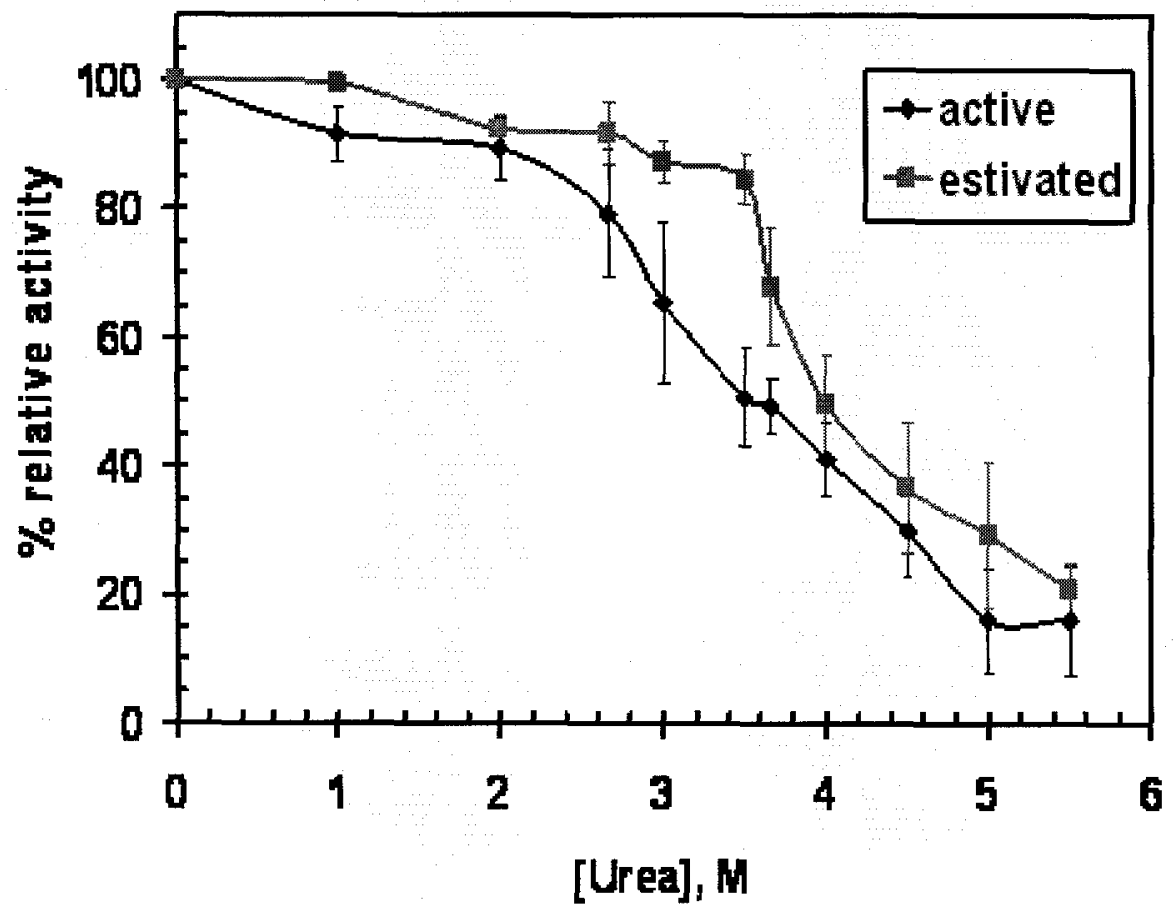




\section{Discussion}

$\mathrm{Na}^{+} \mathrm{K}^{+}$-ATPase harnesses the energy from the hydrolysis of one molecule of ATP to fuel one cycle of transport where three $\mathrm{K}^{+}$ions are pumped into the cell interior at the same time as two $\mathrm{Na}^{+}$ions are actively transported out (Humphrey et al., 2002).

Maintenance of membrane potential difference is essential for nerve and muscle cell excitability, for the proper functioning of renal tissue, and volume regulation, $\mathrm{pH}$ balance, and other functions characteristic of healthy activity in all living cells (Mobasheri et al., 2000). Species that can reversibly enter a hypometabolic state must maintain all of these functions during dormancy but must do so with a much lower net turnover of ATP. Activities of a multitude of cellular functions are turned down in a coordinated manner (Storey and Storey, 2004) with particular attention to highly energy expensive functions such as the ATP costs of maintaining membrane potential difference. Hence, for example, a reduction in facilitated transmembrane ion flow through channels (channel arrest) must be co-ordinated with the suppression of active ion transport by ion pumps to facilitate long term survival in a hypometabolic state. A key mechanism of metabolic rate depression across phylogeny has proven to be reversible protein phosphorylation; the activities of multiple enzymes and functional proteins are suppressed in a coordinated manner by the addition (or removal) of covalently bound phosphate groups that produce major changes in activity states (Storey and Storey, 2004).

Previous studies have documented an overall change in the phosphorylation pattern of cellular proteins during estivation in O. lactea (Brooks and Storey, 1995) as well as specific phosphorylation-mediated suppression of the activities of selected enzymes of carbohydrate catabolism (Whitwam and Storey, 1990, 1991; Brooks and 
Storey, 1992, 1997). The data in the present chapter provides evidence that reversible phosphorylation control during $O$. lactea estivation also extends $\mathrm{Na}^{+} / \mathrm{K}^{+}$-ATPase, an enzyme that is one of the greatest energy consumers in cells. The maximal activity of $\mathrm{Na}^{+} / \mathrm{K}^{+}$-ATPase in muscle and hepatopancreas of estivating snails was reduced by about one-third as compared with active $O$. lactea. A suppression of $\mathrm{Na}^{+} / \mathrm{K}^{+}$-ATPase activity by a similar magnitude also occurred in another hypometabolic system, the hibernating ground squirrel Spermophilus lateralis (MacDonald and Storey, 1999a). Known mechanisms for the acute regulation of the $\mathrm{Na}^{+} \mathrm{K}^{+}$pump can include increased availability of $\mathrm{Na}^{+}$and $\mathrm{K}^{+}$at the membrane, increased affinity for intracellular $\mathrm{Na}^{+}$(as a result of stimulation by hormone or pharmacological agents), differential distribution of the enzyme between sarcolemma and endosome fractions, and increased turnover number of the enzyme (Clausen, 2003). In the longer term, changes in protein synthesis or degradation also influence the net amount of $\mathrm{Na}^{+} \mathrm{K}^{+}$-ATPase protein. Some of these mechanisms cannot be evaluated in a soluble enzyme system. The present study evaluated two aspects of $\mathrm{Na}^{+} \mathrm{K}^{+}$-ATPase in estivation: (a) the amount of enzyme protein present, and (b) stable modification of the enzyme. Western immunoblotting tested the first possibility and revealed that the intensity of the $\sim 100 \mathrm{kDa}$ band representing the alpha subunit of $\mathrm{Na}^{+} \mathrm{K}^{+}$-ATPase was the same in active and estivating snails. Hence, this indicates that the amount of $\mathrm{Na}^{+} \mathrm{K}^{+}$-ATPase protein did not change in $O$. lactea tissues during estivation and supports the idea that a stable modification of the enzyme protein may be responsible for the change in activity state during estivation.

Stable changes to several kinetic parameters of $\mathrm{Na}^{+} \mathrm{K}^{+}$-ATPase occurred between active and estivated states. For $\mathrm{Na}^{+} / \mathrm{K}^{+}$-ATPase from estivated snails, as compared with 
active animals, these included reduced affinity for ATP in both foot muscle and hepatopancreas, reduced affinity for $\mathrm{Na}^{+}$and $\mathrm{Mg}^{2+}$ by the foot muscle enzyme, and increased Arrhenius activation energy for the enzyme from both tissues. The reduced affinities for substrates (ATP, $\left.\mathrm{Na}^{+}\right)$and co-substrates $\left(\mathrm{Mg}^{2+}\right)$ suggest that the enzyme in estivating snails is a less active form which is consistent with metabolic rate depression. Notably, Arrhenius analysis revealed a linear relationship up to $35-38^{\circ} \mathrm{C}$, a considerably higher break point in the temperature-activity relationship when compared to vertebrate $\mathrm{Na}^{+} / \mathrm{K}^{+}$-ATPase studied as the soluble enzyme or the enzyme in membrane preparations (Esmann and Skou, 1988) or as a partially purified enzyme in microsomes (Matsuda and Iwata, 1985). The difference between the Arrhenius profile in this study and previous $\mathrm{Na}^{+} \mathrm{K}^{+}$-ATPase studies might be attributed the fact that $O$. lactea encounters a much wider range of environmental temperatures in nature and needs an enzyme that functions optimally across a broad range of temperatures.

Stable changes in the kinetic properties of an enzyme between two physiological states are often indicative of a post-translational modification of the protein. Vertebrate $\mathrm{Na}^{+} \mathrm{K}^{+}$-ATPase is subject to reversible phosphorylation of the catalytic alpha-subunit by several protein kinases (PKA, PKC, PKG, tyrosine kinase) (Beguin et al., 1994; Ewart and Klip, 1995; Bertorello and Katz, 1995; Lopina, 2001). Phosphorylation by PKA and PKC has been described both in vitro and in vivo as generally having an inhibitory affect on the rate of ATP hydrolysis (Tung et al., 1990; Bertorello et al., 1991; MacDonald and Storey, 1999; Feschenko et al., 2000; Khundmiri et al., 2005). However, in some vertebrate studies, PKA or PKC activation led to an increase in $\mathrm{Na}^{+} \mathrm{K}^{+}$-ATPase activity (Vasilets et al., 1992; Breton et al., 1994; Sampson et al., 1994; Delamere et al., 1997). 
Other research has shown that stimulation of pump activity by phosphorylation is dependent on calcium concentration (Gao et al., 1992; Cheng et al., 1999) or oxygen supply (Kiroytcheva et al., 1999). The B-subunit does not appear to be a target for phosphorylation (Geering, 2001) but the newly recognized $\gamma$-subunit (FXYD protein) as well as other proteins that can bind to $\mathrm{Na}^{+} / \mathrm{K}^{+}$-ATPase can also be susceptible to phosphorylation control (Lopina, 2001; Geering et al., 2003).

We adapted an in vitro experimental design used previously (Storey, 1994) to assess the protein kinases and protein phosphatases that might act on $O$. lactea $\mathrm{Na}^{+} \mathrm{K}^{+}-$ ATPase. The in vitro studies showed that (a) $\mathrm{Na}^{+} \mathrm{K}^{+}$-ATPase activity in extracts from active snails decreased after incubation under conditions that promoted the activities of selected endogenous serine/threonine specific kinases; (b) promoting protein kinase activity inhibited enzyme activity at all $\mathrm{Ca}^{2+}$ concentrations tested; and (c) PKA- and PKG-mediated reductions in enzyme activity were independent of calcium. Incubations that stimulated PKA, PKC or PKG reduced $\mathrm{Na}^{+} \mathrm{K}^{+}$-ATPase activity in both foot muscle and hepatopancreas extracts to levels that were very similar to the activities found in tissue extracts from estivating snails. This implicates phosphorylation by one or more of these protein kinases in the natural mode of suppression of $\mathrm{Na}^{+} \mathrm{K}^{+}$-ATPase activity during estivation and indicates that the less active form found during estivation is probably a phosphoprotein. In addition to modifying enzyme kinetics, a change in phosphorylation state can confer a change in conformational stability. However, the modification of $\mathrm{Na}^{+} \mathrm{K}^{+}$-ATPase activity observed in estivation was not accompanied by a change in enzyme structural stability, since both the active and estivated forms of $O$. lactea $\mathrm{Na}^{+} \mathrm{K}^{+}$ATPase showed similar urea denaturation kinetics in both tissues. 
Interestingly, $\mathrm{Na}^{+} \mathrm{K}^{+}$-ATPase activity in foot muscle (but not hepatopancreas) extracts from estivating snails could be further suppressed after in vitro incubation under conditions that stimulated PKA, PKC, or PKG. This could occur for one of two reasons: (a) $\mathrm{Na}^{+} \mathrm{K}^{+}$-ATPase activity in foot muscle of estivating snails is not fully suppressed to its lowest possible activity state, as it is in hepatopancreas, or (b) the effects of different types of protein kinases on foot muscle $\mathrm{Na}^{+} \mathrm{K}^{+}$-ATPase are additive. With respect to the latter, only one protein kinase may be responsible for the change in enzyme activity in vivo during estivation but stimulation of other kinases in vitro could have an additive effect to further reduce activity. It has been established that $\mathrm{Na}^{+} \mathrm{K}^{+}$-ATPase can be phosphorylated in vivo and in vitro by several protein kinases (Lopina, 2001). PKG is of particular interest to us because it has been implicated in regulating metabolic responses to anoxia (another situation of metabolic rate depression) in marine molluscs including the marine whelk Busycon canaliculatum (Brooks and Storey, 1990), the mussel Mytulis edilus (Michaelidis and Storey, 1990, 1991), and the marine snail Littorina littorea (Larade and Storey, 2002). Phosphorylation of PFK and PK in O. lactea hepatopancreas extracts was also stimulated by incubation with Mg.ATP plus the second messengers of PKA, PKG or PKC (Whitwam and Storey, 1990, 1991) but further studies showed that changes in PKA activity and levels of cAMP and inositol 1,4,5 trisphosphate in $O$. lactea hepatopancreas were not consistent with either PKA or PKC being the kinases involved in mediating estivation-induced phosphorylation of PK (Brooks and Storey, 1994). This suggested that PKG is likely the protein kinase that controls $\mathrm{PK}$ in vivo in $O$. lactea during estivation and this may also be true of $\mathrm{Na}^{+} \mathrm{K}^{+}$-ATPase. PKG control of $O$. lactea $\mathrm{Na}^{+} \mathrm{K}^{+}$-ATPase could provide the estivation-specific regulation of the enzyme during 
metabolic rate depression leaving PKA or PKC to regulate the enzyme in response to other metabolic signals.

The probable role of reversible phosphorylation in the control of O. lactea $\mathrm{Na}^{+} \mathrm{K}^{+}$ATPase during estivation was further supported by the responses of the enzyme to incubations with protein phosphatases. Stimulation of serine/threonine protein phosphatases did not affect the activity of the enzyme from active snails but significantly raised $\mathrm{Na}^{+} \mathrm{K}^{+}$-ATPase activity in extracts from estivated snails, typically returning the enzyme to activity levels similar to those seen in extracts from active snails. Using specific activators and inhibitors, it appeared that stimulation of a phosphatase with characteristic PP1/PP2A-type behaviour was responsible for this effect in both tissues. PP1 can dephosphorylate and activate $\mathrm{Na}^{+} \mathrm{K}^{+}$-ATPase in rat kidney (Li et al., 1995) and rat choroid plexus (Fisone et al., 1998). Hence, it is possible that PP1 may also be involved in changing $\mathrm{Na}^{+} / \mathrm{K}^{+}$-ATPase activity when snails arise from estivation.

Reversible phosphorylation control of mammalian $\mathrm{Na}^{+} \mathrm{K}^{+}$-ATPase activity can also come from activating the phosphoproteins DARPP-32 (a $32 \mathrm{kDa}$ dopamine and cAMP regulated phosphoprotein) and inhibitor-1 (I-1), both of which are well-known as potent inhibitors of PP1 activity when phosphorylated (Higuchi et al., 2000). Hence, by inhibiting PP1, these proteins promote the conversion of $\mathrm{Na}^{+} \mathrm{K}^{+}$-ATPase to the phosphorylated, less active form. The role of these proteins in controlling $\mathrm{Na}^{+} \mathrm{K}^{+}$-ATPase during hypometabolism remains to be determined. Dephosphorylation of $\mathrm{Na}^{+} \mathrm{K}^{+}$-ATPase in human eye lens by protein tyrosine phosphatase-1B was recently reported (Bozulic et al., 2004) but our data suggest that tyrosine-specific phosphatases are likely not involved in $O$. lactea $\mathrm{Na}^{+} \mathrm{K}^{+}$-ATPase control since, in the presence of $\mathrm{NaF}$ which potently inhibits 
all serine/threonine specific phosphatases, no change in enzyme activity was observed. In hepatopancreas extracts, an increase in $\mathrm{Na}^{+} \mathrm{K}^{+}$-ATPase activity also occurred under conditions that inhibited PP1, but stimulated the activity of a magnesium-activated phosphatase. Thus, a phosphatase activity with PP2C-like characteristics could also be involved in $\mathrm{Na}^{+} \mathrm{K}^{+}$-ATPase regulation. In general, physiological roles of PP2C type enzymes have yet to be firmly categorized, and although PP2C activity is reduced in estivating toads (Cowan et al., 2000). PP2C has yet to be characterized in any estivating invertebrate.

In summary, $\mathrm{Na}^{+} \mathrm{K}^{+}$-ATPase activity was significantly reduced in both foot muscle and hepatopancreas in $O$. lactea during estivation, suggesting that suppression of the activity of this ATP-expensive membrane ion pump has a key role to play in the transition to the hypometabolic state. This provides evidence that invertebrate systems of hypometabolism also target $\mathrm{Na}^{+} \mathrm{K}^{+}$-ATPase for regulation, similar to previous reports of $\mathrm{Na}^{+} \mathrm{K}^{+}$-ATPase control in hibernating ground squirrels and anoxia-tolerant turtles (Hochachka et al., 1996; MacDonald and Storey, 1999). Suppression of $\mathrm{Na}^{+} \mathrm{K}^{+}$-ATPase during estivation was not a function of changes in the amount of the catalytic alpha subunit of the protein but appeared to be linked to posttranslational modification of the enzyme. The enzyme from estivating snails and was characterized by reduced maximal velocity, increased $K_{m}$ ATP, and elevated activation energy in both tissues, as compared with active snails. In vitro incubations that manipulated endogenous kinase and phosphatase activities implicated PKA, PKC, or PKG action in $\mathrm{Na}^{+} \mathrm{K}^{+}$-ATPase suppression during estivation whereas PP1 or PP2A phosphatases may mediate the reactivation of the enzyme during arousal. 


\section{CHAPTER 3 \\ Glucose-6-phosphate dehydrogenase regulation in Otala lactea during estivation}




\section{Introduction}

Glucose-6-phosphate dehydrogenase (G6PDH) (E.C. 1.1.1.49) catalyzes the first of two oxidative steps in the pentose phosphate pathway and influences the rate of pathway function:

D-glucose-6-phosphate $+\mathrm{NADP}^{+} \rightarrow$ D-glucono-1,5-lactone 6-phosphate $+\mathrm{NADPH}+\mathrm{H}^{+}$ The lactone is immediately hydrolyzed to form 6-phosphogluconate, the substrate of the second NADPH-producing reaction. The pentose phosphate pathway has several important functions in cells (discussed in Chapter 1); of particular relevance to the estivating snail is the production of reducing equivalents in the form of NADPH which are used in antioxidant defense. Protection against oxidative stress is needed for several reasons during dormancy: (a) for long term protection of macromolecules in the hypometabolic state where the rates of biosynthesis of new macromolecules are low, (b) to cope with a rapid, large increase in oxyradical formation associated with arousal from dormancy when oxygen consumption increases rapidly, and (c) to deal with intermittent sharp increases in tissue oxygenation (and oxyradical formation) due to discontinuous breathing patterns during estivation. Studies have shown that antioxidant defenses are elevated in dormant snails to protect cells from oxidative injuries during estivation (Hermes-Lima and Storey, 1995; Hermes-Lima et al., 1998; Storey and Storey, 2004).

It has been recently established that mammalian G6PDH activity can be regulated by reversible phosphorylation (Costa Rosa et al., 1995; Zhang et al., 2000; Xu et al., 2005), although these studies were limited to examining the effect of phosphorylation on maximal velocity (which decreased). It remains to be determined how phosphorylation affects G6PDH kinetic properties, as well as how the phosphorylation state of the enzyme 
responds in animal systems that depress metabolic rate. On the one hand, suppression of G6PDH activity could be predicted so that pentose phosphate cycle activity is reduced in concert with the general suppression of carbohydrate catabolism. On the other hand, maintenance or perhaps even enhancement of NADPH supply is paramount to sustaining antioxidant defenses during long term dormancy. The present study examines G6PDH regulation in the estivating land snail, $O$. lactea. I hypothesized that G6PDH would be differentially regulated in estivation, and the mechanism responsible would be phosphorylation.

\section{Methods and Materials}

\section{Animals and Chemicals}

Snails were cared for, estivation was induced, and hepatopancreas was harvested as described in Chapter 2. Phosphatase inhibitors were purchases from Calbiochem (La Jolla, CA), and all other chemicals were purchased from Sigma.

\section{Sample preparation}

Frozen hepatopancreas samples were homogenized (1:5 w:v) in ice-cold buffer A containing $25 \mathrm{mM}$ imidazole, pH 7.5, $10 \%$ v:v glycerol, $10 \mathrm{mM}$ 2-mercaptoethanol, 25 mM NaF, 2 mM EDTA and 2 mM EGTA using a Polytron PT1000 homogenizer (Brinkmann Instruments, Rexdale, ON). Initial trials optimized NaF, EDTA and EGTA concentrations with respect to amount of recoverable enzyme activity. A few crystals of the protease inhibitor, phenylmethylsulfonyl fluoride (PMSF), were added at the time of homogenization. After centrifugation at $10,000 \mathrm{x}$ for $20 \mathrm{~min}$, the supernatant was 
removed and held on ice.

\section{Partial purification of G6PDH}

A $500 \mu \mathrm{L}$ aliquot of supernatant was added to a $2 \mathrm{~cm} \mathrm{x} 1.8 \mathrm{~cm}(\mathrm{~h} \times \mathrm{d})$ column of DEAE G25 Sephadex (equilibrated in buffer $\mathrm{A}$ at $\mathrm{pH}$ 8.0) and then the column was washed with $10 \mathrm{~mL}$ of the same buffer to remove unbound proteins. G6PDH was eluted with a $0-2 \mathrm{M}$ gradient of $\mathrm{NaCl}$ in buffer $\mathrm{A}$ and $200 \mu \mathrm{L}$ fractions were collected in test tubes with a Gilson MicroFractionator (Middleton, WI, USA).

\section{G6PDH assay}

Optimum assay conditions for G6PDH were $1 \mathrm{mM} \mathrm{NADP}{ }^{+}, 5 \mathrm{mM} \mathrm{G6P,} 25 \mathrm{mM}$ imidazole, pH 7.8. Reactions were initiated by adding $10 \mu \mathrm{L}$ of crude extract or $100 \mu \mathrm{L}$ of column fractions to a $200 \mu \mathrm{L}$ total reaction volume in the microplate well. Activity was monitored at $340 \mathrm{~nm}$ using a MR5000 microplate reader from Dynatech Laboratories (Chantilly, VA, USA) and Biolinx 2.0 software (Brockville, ON), Microplate Analysis (MPA) and Kinetics 3.51 computer programs used to analyze the data (Brooks, 1992; 1994). Activities are reported in $\mathrm{mU} / \mathrm{mg}$ protein. Soluble protein content was quantified using the Coomassie Blue dye binding method and the BioRad prepared reagent with a standard curve of bovine serum albumin.

\section{In vitro incubations to stimulate endogenous kinases and phosphatases}

To assess the effects of phosphorylation state on G6PDH activity, tissue extracts were prepared in buffer A and subsequently incubated under conditions that promoted 
either protein phosphorylation or protein dephosphorylation (protocol modified from Storey, 1994). Incubation times were $4 \mathrm{~h}$ at room temperature when assessing G6PDH in crude extracts or $12 \mathrm{~h}$ when assessing fractions from DEAE-Sephadex. Enzyme samples were mixed 1:2 v:v with buffer B (25 mM imidazole, $\mathrm{pH} 7.5,10 \% \mathrm{v} / \mathrm{v}$ glycerol, $10 \mathrm{mM}$ 2-mercaptoethanol), containing one of the following additions.

(A) Control incubations: $25 \mathrm{mM} \mathrm{NaF,} 2 \mathrm{mM}$ EDTA, 2 mM EGTA to inhibit all phosphatase and kinase activities.

(B) Stimulation of endogenous protein kinase activities: $5 \mathrm{mM} \mathrm{Mg} . \mathrm{ATP}, 25 \mathrm{mM}$ $\mathrm{NaF}$ and either (1) $1 \mathrm{mM}$ cAMP to stimulate PKA; (2) $1 \mathrm{mM} \mathrm{cGMP}$ to stimulate PKG; (3) $1.3 \mathrm{mM} \mathrm{CaCl} 2+7 \mathrm{ug} / \mathrm{mL}$ phorbol myristate acetate to stimulate PKC; (4) $1 \mathrm{mM} \mathrm{AMP}$ to stimulate AMPK; or (5) $1 \mathrm{U}$ of calmodulin activity/incubation tube $+1.3 \mathrm{mM} \mathrm{CaCl}_{2}$ to stimulate CaMK.

(C) Stimulation of endogenous protein phosphatases (PPase): (1) for total PPase activity: $5 \mathrm{mM} \mathrm{CaCl}_{2}+5 \mathrm{mM} \mathrm{MgCl}_{2}$; (2) for PP1: $2.5 \mathrm{nM}$ okadaic acid (inhibits PP2A) + 2 mM EDTA + 2 mM EGTA; (3) for PP1 + PP2A: 2 mM EDTA and 2 mM EGTA; (4) for total PPase minus PP1/PP2A: $1 \mu \mathrm{M}$ okadaic acid $+5 \mathrm{mM} \mathrm{CaCl}_{2}+5 \mathrm{mM} \mathrm{MgCl}_{2}$; (5) for PP2B: $1 \mu \mathrm{M}$ okadaic acid $+5 \mathrm{mM} \mathrm{CaCl}_{2}+2 \mathrm{mM}$ EDTA; (6) for PP2C: $1 \mu \mathrm{M}$ okadaic acid + $5 \mathrm{mM} \mathrm{MgCl} 2+2 \mathrm{mM}$ EGTA; (7) for full dephosphorylation: incubation with $1 \mathrm{U}$ calf intestinal alkaline phosphatase (AP) $+5 \mathrm{mM} \mathrm{MgCl}_{2}+5 \mathrm{mM} \mathrm{CaCl}$.

After incubation, all samples were desalted by low speed centrifugation through small columns of G25-Sephadex equilibrated in buffer B followed by assay under optimum conditions. 


\section{Pulse proteolysis of partially purified G6PDH}

To assess changes in the structural stability of the two peaks of G6PDH activity eluted from the DEAE column, the enzyme was subjected to denaturation with urea and subsequent thermolysin-mediated proteolysis, methods adapted from Park and Marqusee (2005) and Tamarappoo et al. (1999). Hepatopancreas extracts were prepared as previously in buffer A but without the addition of PMSF, centrifuged, and the supernatant was fractionated by DEAE G25 Sephadex chromatography, as described above. Peak fractions were pooled and $50 \mu \mathrm{L}$ aliquots of each peak were incubated with $100 \mu \mathrm{L}$ of a urea solution made up in buffer A. After $24 \mathrm{~h}$ incubation at room temperature, extracts were treated with $10 \mu \mathrm{L}$ of $10 \mathrm{mg} / \mathrm{mL}$ thermolysin (Sigma; stock prepared with $2.5 \mathrm{M}$ $\mathrm{NaCl}$ and $10 \mathrm{mM} \mathrm{CaCl}_{2}$ ). Thermolysin activity was stopped after $10 \mathrm{~min}$ by the addition of $20 \mu \mathrm{L}$ of $50 \mathrm{mM}$ EDTA (pH 8.0). Enzyme protein content was measured by Western blotting. Parallel experiments were performed to determine enzyme activity as a function of urea concentration. Parameters of protein unfolding and activity inhibition due to urea were calculated using the Kinetics program.

\section{Western Blotting}

Preparation, loading, electrophoresis, and transfer to PVDF membranes of partially purified Peak I and II G6PDH samples were performed essentially as described in Chapter 2. PVDF membranes were blocked with $1 \%$ non-fat dried milk in TBST for 30 $\min$ at $4^{\circ} \mathrm{C}$. The membranes were then incubated overnight at $4^{\circ} \mathrm{C}$ with G6PDH primary antibody (Sigma; rabbit anti-G6PDH raised against antigen from $S$. cerevisiae; stock prepared following manufacturer's directions and diluted 1:1000 v:v in TBST). Unbound 
primary antibody was removed with $3 \times 5$ min washes with TBST and then the membrane was incubated with HRP-conjugated anti-rabbit secondary antibody (Santa Cruz Biotechnology, diluted 1:2000 v:v in TBST) for 2-3 $\mathrm{h}$ at room temperature, followed by $3 \times 5$ min washes in TBST. Proteins were visualized using Western Lightning Chemiluminescence Plus reagents (Perkin Elmer, Boston, MA) and ECL signal was detected using the ChemiGenius bio-imaging system (Syngene, Frederick, MD) and quantified using GeneTools software (v3.00.02), as described in Chapter 2. BioRad Kaleidoscope pre-stained markers were run in selected lanes and used to assess the molecular mass of the test protein.

\section{Arrhenius analysis}

Enzyme assays were performed under $V_{\max }$ conditions over the temperature range $4^{\circ} \mathrm{C}-45^{\circ} \mathrm{C}$. Activation energy (Ea) was determined in $\mathrm{kJ} / \mathrm{mol}$ for linear portions of the relationship. For temperature control, the MR5000 microplate reader was equilibrated to the appropriate temperature in a Precision 815 low temperature incubator. Assay plates were also equilibrated in the incubator for $\sim 10 \mathrm{~min}$ before reactions were initiated by the addition of enzyme.

\section{Results}

\section{Optimization of experimental conditions}

Inclusion of EDTA and EGTA in homogenizing buffer did not affect the recoverable G6PDH activity in hepatopancreas extracts from either active or estivating snails whereas inclusion of $\mathrm{NaF}$ substantially improved recoverable activity. However, use of alternate phosphatase inhibitors ( $\left(\mathrm{B}\right.$-glycerophosphate, $\mathrm{Na}_{3} \mathrm{VO}_{4}$ ) reduced 
recoverable activity. Thus, $\mathrm{NaF}$, EDTA, and EGTA were used in the standard homogenizing buffer. Figure 3.1 shows the $\mathrm{pH}$ optima of G6PDH from active and estivated snails; the optimum for the enzyme from estivated snails was $\mathrm{pH} 7.8$ compared with a slightly higher value of 8.0 for active snails (although activity for the enzyme from active snails at $\mathrm{pH} 7.8$ was not significantly different from that at $\mathrm{pH} 8.0$ ). Throughout the study, standard assays were performed at $\mathrm{pH}$ 7.8. Initial trials optimized reaction time and amount of extract used, as described in Chapter 2.

\section{Kinetic parameters}

The maximal activity of G6PDH in crude extracts from hepatopancreas of estivating snails was 1.5 fold higher than the value in active snails (Table 3.1). Velocity versus substrate concentration curves for hepatopancreas G6PDH are shown in Figure 3.2. The enzyme displayed sigmoidal kinetics with respect to $\mathrm{NADP}^{+}$concentration, with Hill coefficients ranging between 1.8 and 2.4; the same relationship was seen with both crude extracts and partially purified preparations after DEAE G25 Sephadex chromatography. However, the $\mathrm{S}_{0.5} \mathrm{NADP}^{+}$did not change between active and estivated states (Table 3.1). G6PDH displayed hyperbolic kinetics with respect to G6P and significantly different $K_{m}$ values between active and estivated states. $K_{m}$ G6P values for the enzyme in crude extracts from estivated snails decreased to $54 \%$ of the value for G6PDH from active snails indicating substantially higher affinity for this substrate in the estivating animal. Snail G6PDH was inhibited by $\mathrm{Mg}^{2+}$-citrate and the $\mathrm{K}_{\mathrm{a}}$ for citrate also decreased during estivation to a value that was $65 \%$ of the $\mathrm{K}_{\mathrm{a}}$ for active animals. 
In vitro incubations to assess changes in G6PDH activity as a result of phosphorylation state

Aliquots of crude extracts of hepatopancreas from active and $10 \mathrm{~d}$ estivated snails were incubated under conditions that stimulate the activities of endogenous protein kinases or protein phosphatases and the effects on G6PDH maximal activity were determined. Figure 3.3A shows that stimulation of PKA or PKG activities in crude extracts from active snails produced 1.4 fold increases in G6PDH activity, raising Vmax to the activity seen during estivation. Stimulation of other kinases failed to alter G6PDH activity in extracts from active snails, and none of the kinase treatments had any effect on G6PDH from estivated snails. Conversely, G6PDH $\mathrm{V}_{\max }$ activity in preparations from active snails was not affected by any of the treatments that stimulated endogenous protein phosphatase activities, nor was it activity affected by incubation with AP (Figure 3.3B). However, stimulation of several phosphatase classes reduced G6PDH activity in extracts from estivated snails. This included stimulation of total serine/threonine phosphatase activity, PP1-type activity, and PP1/PP2A-type activity; G6PDH $\mathrm{V}_{\max }$ fell to $68 \%, 72 \%$, and $77 \%$, respectively, of the $\mathrm{V}_{\max }$ of G6PDH in control incubations. Incubation with AP also strongly reduced G6PDH activity to $46 \%$ of that in the control condition.

\section{Ion exchange chromatography of high and low phosphate forms of G6PDH}

DEAE-G25 Sephadex chromatography resolved two peaks of G6PDH activity from crude hepatopancreas extracts of both active and estivated snails. Peak I consistently eluted at $0.6-1.0 \mathrm{M} \mathrm{NaCl}$ and Peak II eluted at 1.1-1.6 M NaCl. A typical elution profile for G6PDH activity from active snails is seen in Figure 3.4A; peak I 
dominated in active snails containing $57 \pm 5 \%(\mathrm{n}=3)$ of the total activity compared with $43 \pm 5 \%$ in Peak II. The elution pattern changed markedly when extracts from estivated snails were resolved. The amount of activity in peak II increased greatly to $78 \pm 7 \%$ $(n=3)$ of total activity recovered from the column (Figure 3.4B).

In vitro treatments that stimulated selected kinases and phosphatases strongly altered the elution profile of G6PDH on the ion exchange column. When hepatopancreas extracts from active snails were incubated for $12 \mathrm{~h}$ under conditions that stimulated endogenous protein kinase A, the G6PDH elution profile shifted to resemble the pattern seen during estivation with $71 \pm 6 \%(n=3)$ of total activity in peak II (Figure 3.4C). Conversely, when extracts from estivated snails were incubated for $12 \mathrm{~h}$ under conditions that promoted endogenous PP1 activity, the profile shifted to resemble the elution profile of G6PDH in active snails with the greater proportion of activity in peak I $(56 \pm 7 \%, \mathrm{n}=3)$ (Figure 3.4D). Incubation of extracts from active snails under conditions that stimulated PKG resulted in the shift of $100 \%$ of activity into a single peak, eluting at $1.2-1.6 \mathrm{M}$ $\mathrm{NaCl}$, consistent with Peak II activity from the other conditions (Figure 3.4E). Finally, when extracts from estivated snails were incubated with AP, only one peak of activity was found, eluting at $0.6-1.0 \mathrm{M} \mathrm{NaCl}$ and consistent with Peak I G6PDH in the other profiles (Figure 3.4F).

Kinetic properties were assessed for the two pooled peaks of G6PDH activity from active snails (Table 3.1). As compared with the Peak I enzyme, peak II G6PDH had a significantly lower $K_{m}$ G6P (37\% of the peak I value) and a significantly lower $K_{a}$ for Mg.citrate (45\% of the peak I value). The properties of the peak I enzyme mimicked those of the enzyme from active snails whereas peak II G6PDH showed properties very 
similar to the enzyme from estivated snails.

The response of G6PDH to temperature was also evaluated. Arrhenius plots were linear from $4^{\circ} \mathrm{C}$ to $\sim 30^{\circ} \mathrm{C}$ (Figure 3.5) and calculated activation energies are shown in Table 3.1. The $\mathrm{E}_{\mathrm{a}}$ for Peak II G6PDH was significantly lower than the value for the peak I enzyme and resembled the value for the enzyme from estivated snails whereas the peak I value was similar to the value for active snails.

\section{Urea denaturation and pulse proteolysis}

The structural integrity of enzymes can be changed by covalent modification (or by the presence of allosteric modifiers) making a protein more or less susceptible to denaturation by urea and subsequent proteolytic attack on the denatured (unfolded) enzyme by thermolysin. Hence, the pulse proteolysis technique is an effective way to determine whether there are structural or conformational differences in a protein between two different physiological states. Pulse proteolysis of resolved Peak I and Peak II G6PDH populations from extracts of active snails was conducted with thermolysin following incubation of the enzymes with different concentrations of urea to achieve different degrees of protein denaturation. The results revealed that Peak II G6PDH had significantly higher resistance to unfolding and denaturation by urea, relative to the Peak I enzyme (Figure 3.6). This was evident both from the $I_{50}$ value (the amount of urea required to inhibit $50 \%$ of activity) and from the $C_{m}$ value (the amount of urea required to unfold $50 \%$ of the protein, rendering it susceptible to thermolysin proteolysis) (Table 3.1). Both values were 4.3-4.4 M urea for the peak I enzyme and $20 \%$ higher at 5.2-5.3 M for peak II G6PDH. 
Table 3.1. Kinetic parameters for G6PDH from hepatopancreas of active and $10 \mathrm{~d}$ estivated $O$. lactea and for Peak I and II G6PDH separated by DEAE chromatography.

\begin{tabular}{lllll}
\hline & Active & Estivated & Peak I & Peak II \\
\hline $\mathrm{V}_{\max }(\mathrm{mU} / \mathrm{mg})$ & $54 \pm 5$ & $79 \pm 8^{*}$ & $316 \pm 42$ & $552 \pm 52^{* *}$ \\
$\mathrm{~K}_{\mathrm{m}} \mathrm{G} 6 \mathrm{P}(\mathrm{mM})$ & $1.41 \pm 0.30$ & $0.76 \pm 0.26^{*}$ & $1.68 \pm 0.48$ & $0.62 \pm 0.33^{* * *}$ \\
$\mathrm{~S}_{0.50} \mathrm{NADP}^{+}(\mathrm{mM})$ & $0.21 \pm 0.05$ & $0.19 \pm 0.04$ & $0.25 \pm 0.08$ & $0.19 \pm 0.08$ \\
$\mathrm{I}_{50} \mathrm{Mg}^{2+}$-citrate $(\mathrm{mM})$ & $2.6 \pm 0.5$ & $1.7 \pm 0.4^{*}$ & $3.1 \pm 0.8$ & $1.4 \pm 0.5^{* *}$ \\
$\mathrm{E}_{\mathrm{a}}(\mathrm{kJ} / \mathrm{mol})$ & $31.4 \pm 6.6$ & $26.2 \pm 5.1$ & $37.0 \pm 4.3$ & $24.2 \pm 4.9^{* *}$ \\
$\mathrm{I}_{50}$ urea $(\mathrm{M})$ & $\mathrm{ND}$ & $\mathrm{ND}$ & $4.4 \pm 0.2$ & $5.3 \pm 0.3^{* *}$ \\
$\mathrm{C}_{\mathrm{m}}$ urea $(\mathrm{M})$ & $\mathrm{ND}$ & $\mathrm{ND}$ & $4.3 \pm 0.1$ & $5.2 \pm 0.3^{* *}$ \\
\hline
\end{tabular}

Assays were conducted at $22^{\circ} \mathrm{C}$ (except for Arrhenius plots) and data are means \pm S.E.M. ( $\mathrm{n}=3$ for $\mathrm{C}_{\mathrm{m}}$ and $\mathrm{I}_{50}$ for urea, $\mathrm{n}=4$ for all other parameters). $\mathrm{I}_{50}$ is the concentration of urea that reduces enzyme activity by $50 \% . \mathrm{C}_{\mathrm{m}}$ is the concentration of urea required to unfold $50 \%$ of the protein. Kinetic constants were determined at optimal concentrations of ions or cosubstrates. Peak I and Peak II parameters were assessed for G6PDH in DEAE-G25 Sephadex elution peaks recovered from active snail extracts. Significance testing used the Student's t-test. *- Significantly different from the corresponding value for active snails, $\mathrm{P}<0.05 ; * *$-significantly different from the corresponding Peak I value, $\mathrm{P}<0.05$. ND - not determined for these preparations. 
Figure 3.1. Determination of optimal $\mathrm{pH}$ for G6PDH activity from hepatopancreas of active and estivated $O$. lactea. Optimal assay conditions were used at $22^{\circ} \mathrm{C}$ with $\mathrm{pH}$ of the imidazole adjusted to the values shown. Data are means $\pm \mathrm{SEM}, \mathrm{n}=4$. 


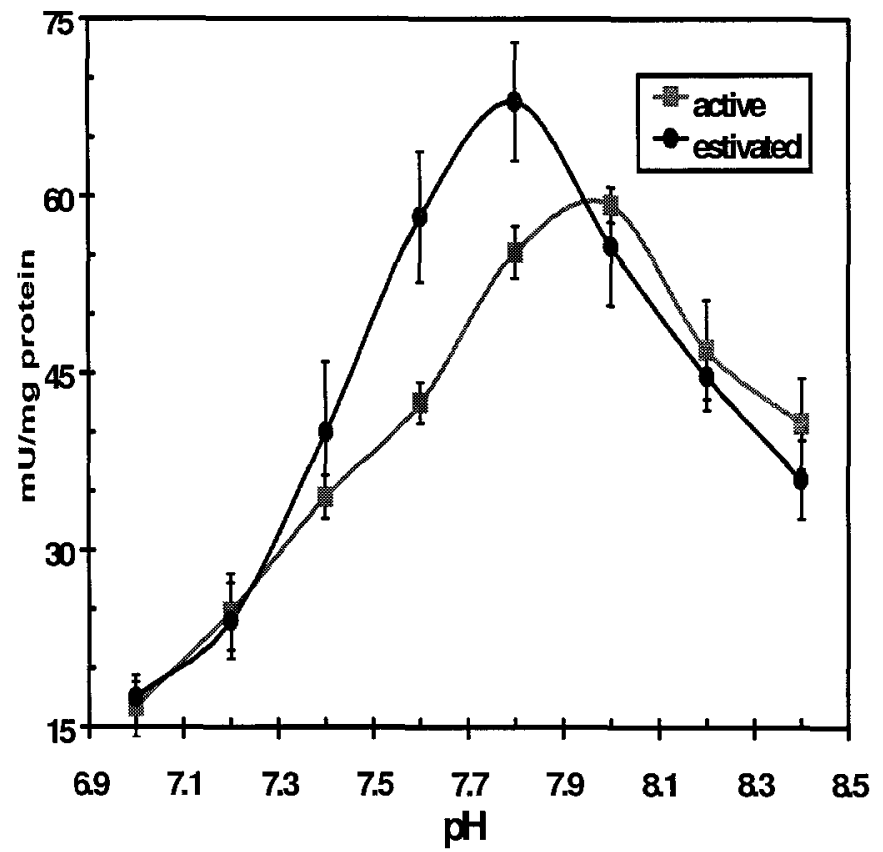


Figure 3.2. Velocity versus substrate concentration for G6PDH activity from hepatopancreas of active and estivated $O$. lactea showing (A) activity as a function of G6P concentration at $1 \mathrm{mM}$ NADP, and (B) activity as a function of NADP concentration at $5 \mathrm{mM}$ G6P. Results are for assays on crude extracts; data are means $\pm \mathrm{SEM}, \mathrm{n}=4$. 
A.

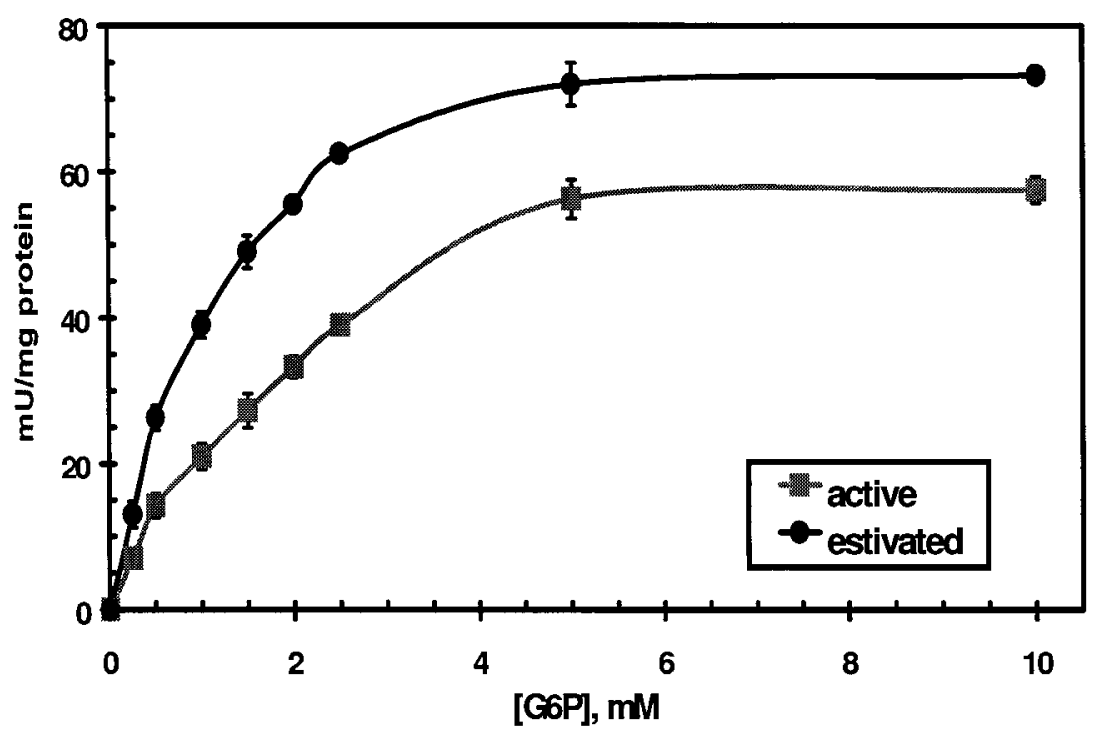

B.

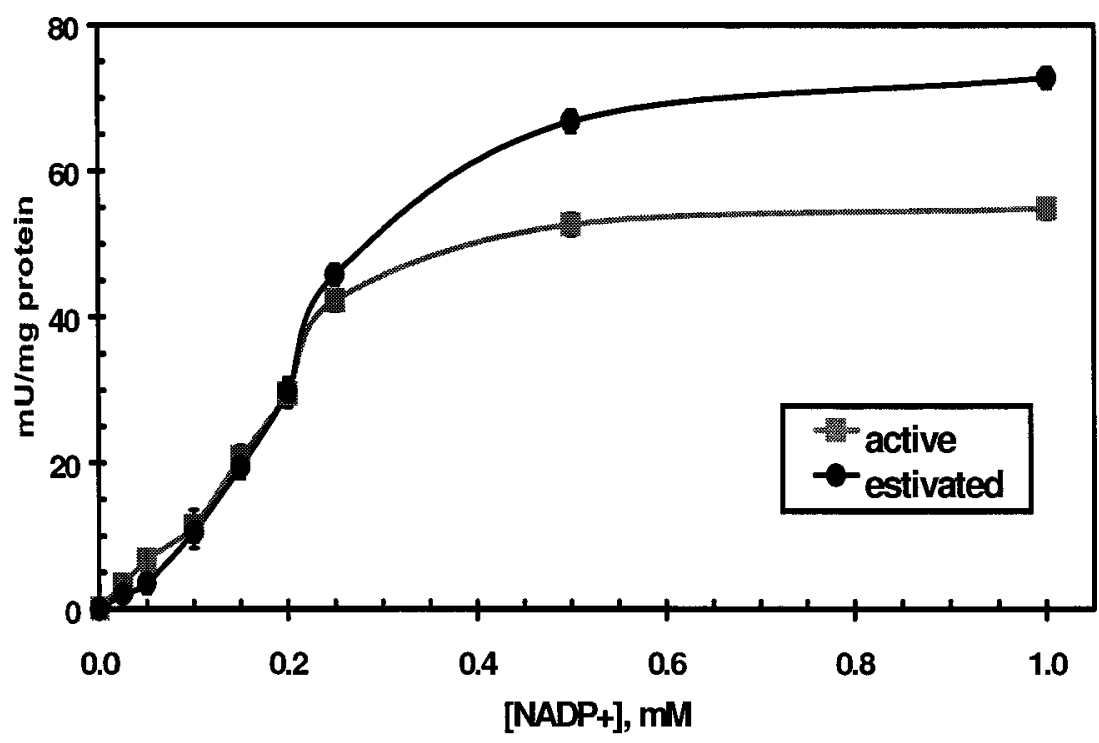


Figure 3.3. Effects of in vitro incubations to stimulate the activities of (A) protein kinases or (B) protein phosphatases on the maximal activity of G6PDH from $O$. lactea hepatopancreas. Crude extracts were incubated for $4 \mathrm{~h}$ before assay at $22^{\circ} \mathrm{C}$. Data are means \pm SEM, $n=4$ independent determinations. a - Significantly different from the corresponding control value (no additions) using the Student's t-test, $\mathrm{P}<0.01 ; \mathrm{b}-\mathrm{P}<0.05$. 
A.

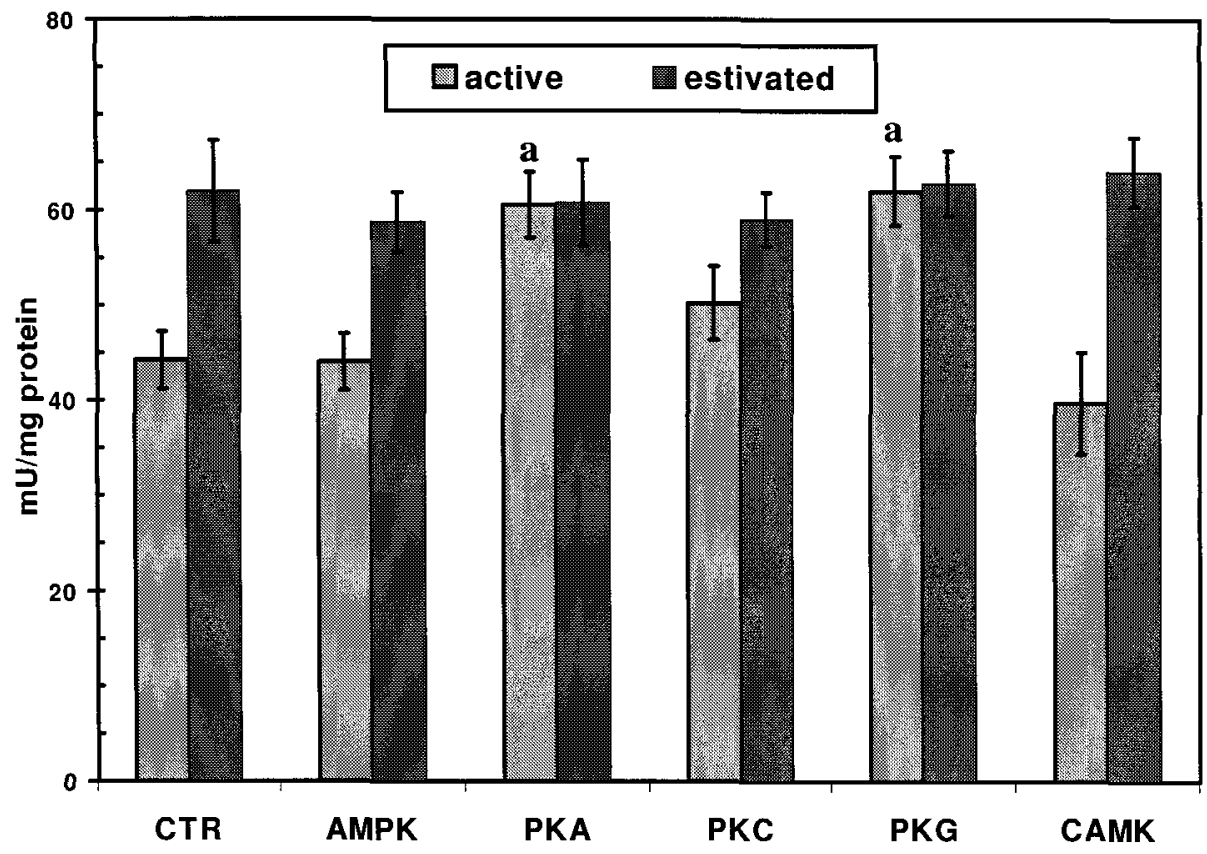

B.

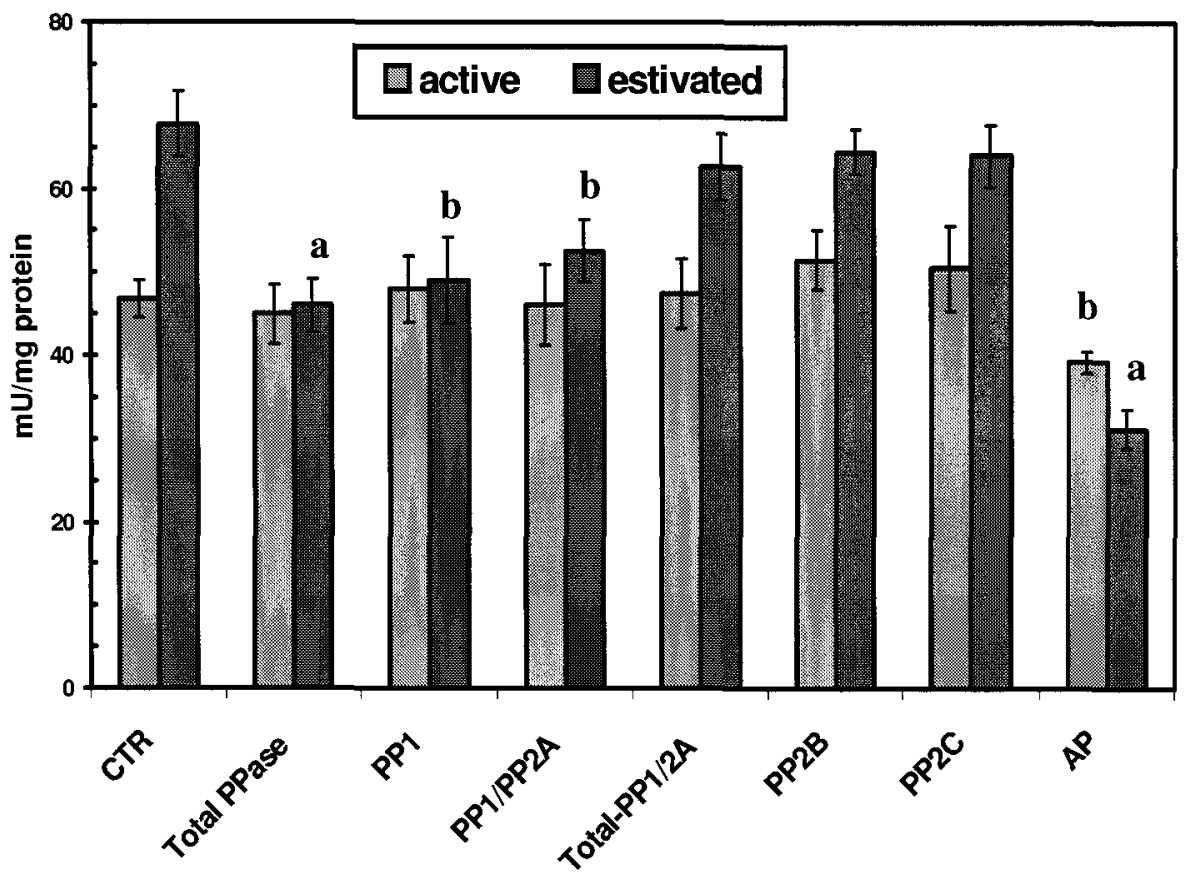


Figure 3.4. DEAE-G25 Sephadex elution profiles for G6PDH activity from hepatopancreas of active and estivating $O$. lactea. Profiles are representative of three or more independent determinations for each condition. Activities are expressed relative to the highest activity fraction. Peaks I and II eluted at lower and higher $\mathrm{NaCl}$ concentrations, respectively. Panels show (A) G6PDH elution profile of untreated hepatopancreas extracts of active snails, (B) G6PDH from untreated hepatopancreas extracts of estivating snails, (C) G6PDH from active snails after $12 \mathrm{~h}$ incubation to stimulate endogenous PKA, (D) G6PDH from estivating snails after 12 hour incubation to stimulate endogenous PP1, (E) G6PDH from active snails after $12 \mathrm{~h}$ incubation to stimulate endogenous PKG, and (F) G6PDH from estivating snails after $12 \mathrm{~h}$ incubation with alkaline phosphatase. Details of incubations are in the Materials and Methods. 

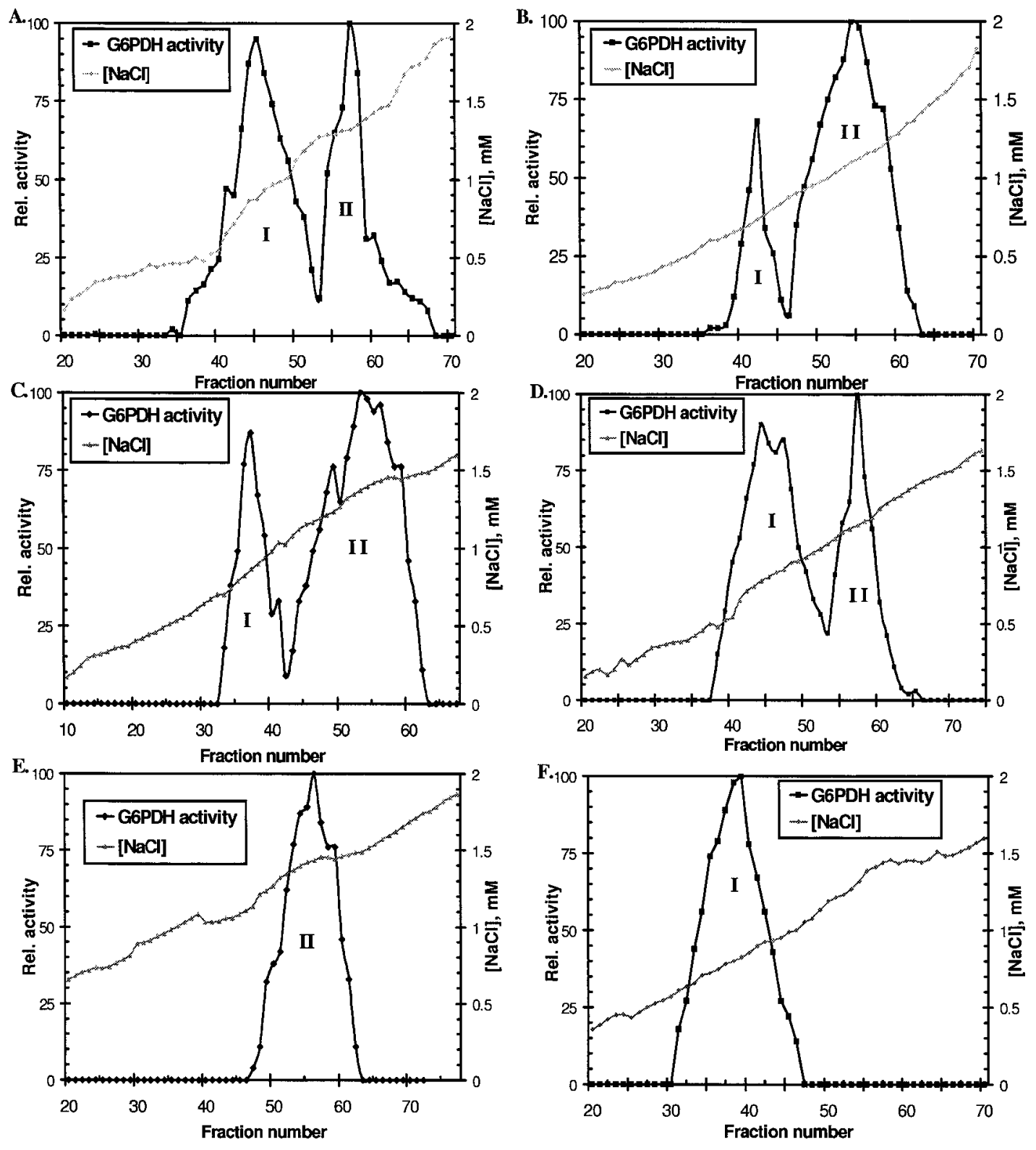
Figure 3.5. Representative Arrhenius plots for $O$. lactea hepatopancreas G6PDH activity comparing the enzyme from crude extracts of active and estivated snails as well as the Peak I and II fractions from DEAE-G25 Sephadex separations. Activities were measured under optimal conditions between 4 and $45^{\circ} \mathrm{C}$. 


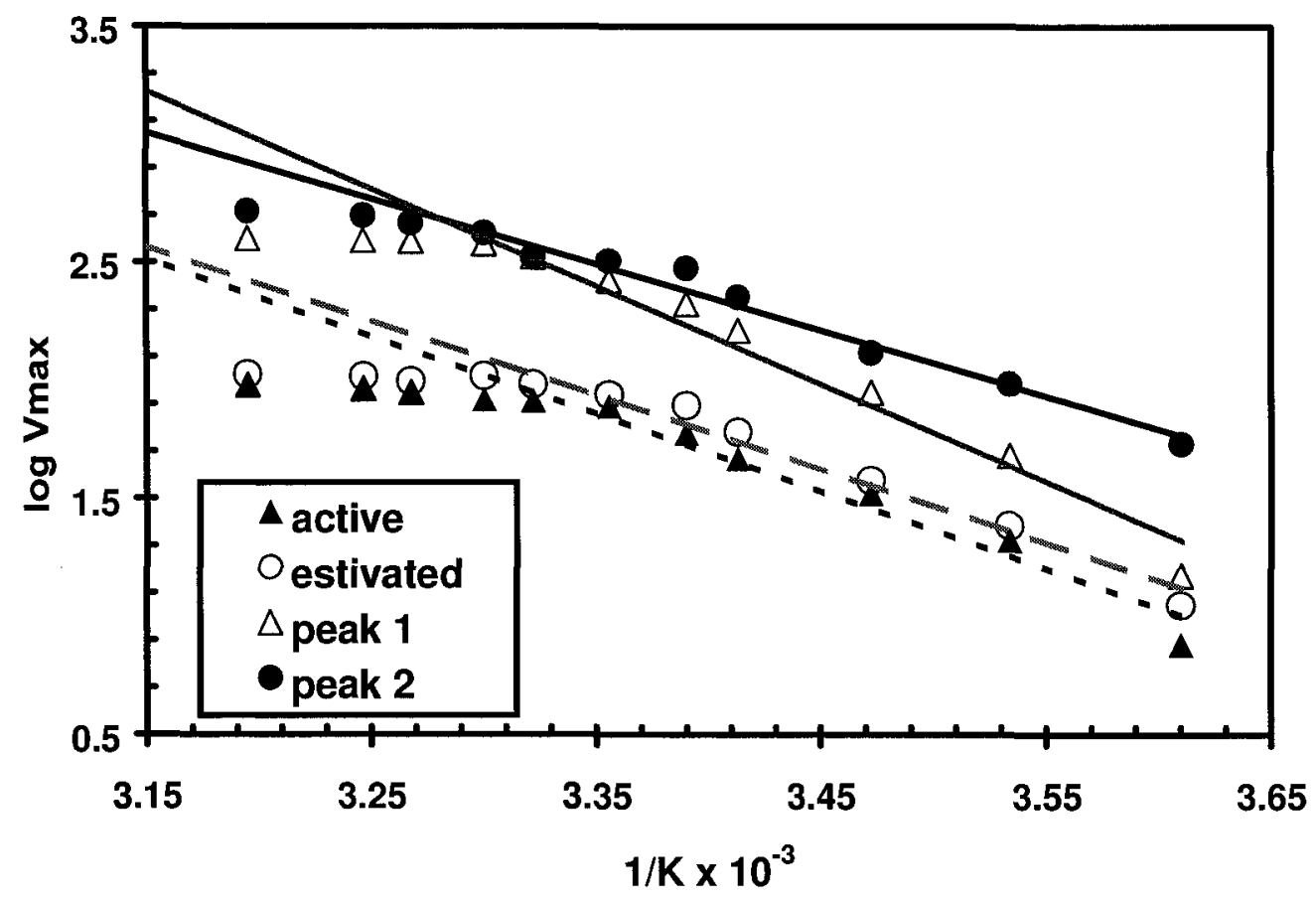


Figure 3.6. Structural unfolding and enzymatic inhibition by urea of peak I and II G6PDH from hepatopancreas of active snails. Pooled enzyme from each peak was denatured overnight with different concentrations of urea and then either treated with thermolysin or assayed under optimal conditions. (A) Representative Western blot detecting the $\sim 60 \mathrm{kDa}$ band of G6PDH protein from pooled Peak I samples and showing the amount of G6PDH protein remaining after proteolysis as a function of urea concentration (0-7 M). (B) Comparable Western blots for G6PDH protein from pooled Peak II samples. (C) Mean relative G6PDH protein content remaining after overnight incubation with urea and subsequent proteolysis with thermolysin. (D) Mean relative G6PDH activity in pooled Peak I and pooled Peak II samples from active snails as a function of overnight incubation with different concentrations of urea. Histogram data are means $\pm S E M, n=3$. 

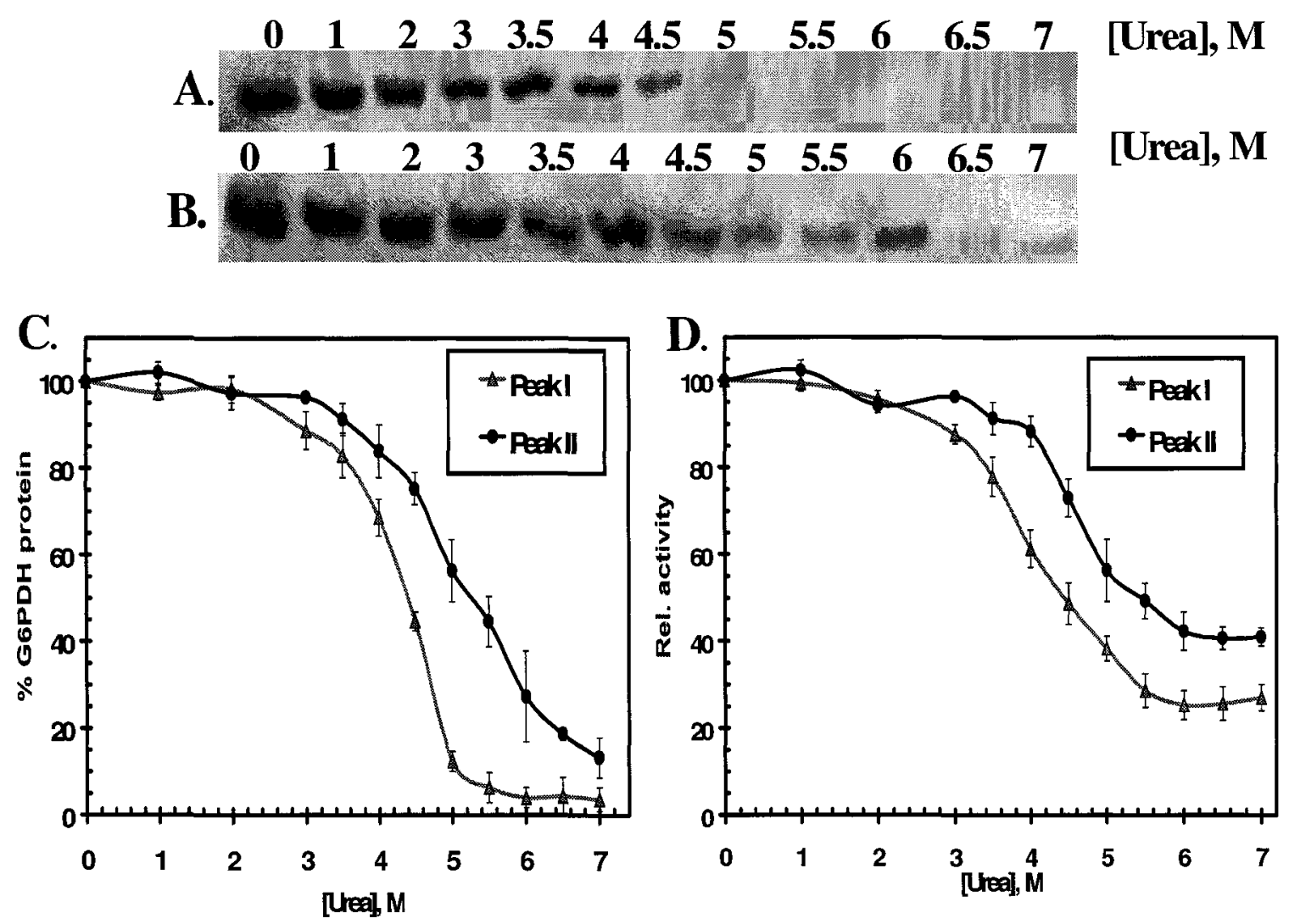


\section{Discussion}

G6PDH from the hepatopancreas of the terrestrial gastropod $O$. lactea is likely subject to reversible phosphorylation and the data indicate that this mechanism underlies the estivation-induced changes in activity and kinetic/thermal properties of the enzyme as well as its susceptibility to urea denaturation. This is the first time that phosphorylation control of a pentose phosphate cycle enzyme has been implicated as a component of metabolic rate depression in a system of natural hypometabolism and suggests that pentose phosphate cycle flux is another of the metabolic functions that are targeted for coordinated control in animals switching between active and torpid states. It will be interesting to determine whether G6PDH and the pentose phosphate pathway are also regulated in other tissues and other species during hypometabolism. Preliminary studies of foot muscle and mantle G6PDH in O. lactea showed no change in the $\mathrm{V}_{\max }$ or substrate kinetics during estivation (data not shown) and Ramos-Vasconcelos and Hermes-Lima (2003) reported no change in G6PDH $\mathrm{V}_{\max }$ in another estivating snail, Helix aspersa, but kinetic properties were not examined. The central role of the liver or liver-like organs of animals in biosynthesis, antioxidant defense and xenobiotic detoxification may mean that regulation of G6PDH in hepatopancreas is particularly important and is specifically targeted for regulatory control during hypometabolism.

Several of the properties of hepatopancreas G6PDH were significantly different between active and estivated states. Notably, the $\mathrm{K}_{\mathrm{m}}$ for G6P was significantly lower during estivation and mirrored the value for the peak II high phosphate form of the enzyme. Hence, it is apparent that estivation triggers the phosphorylation of hepatopancreas G6PDH and elevates its affinity for hexose phosphate substrate. A 
previous study found that G6P substrate levels were reduced by $>67 \%$ in hepatopancreas of estivating snails, compared with active animals (Churchill and Storey 1989), so the increase in substrate affinity of G6PDH during estivation could help to realign enzyme activity with substrate availability. Interestingly, O. lactea hepatopancreas PFK, the key regulatory enzyme of glycolysis, showed the opposite response during estivation. PFK affinity for its substrate, fructose-6-phosphate, was significantly reduced during estivation (the enzyme also showed reduced sensitivity to its activator, fructose-2,6bisphosphate) and these changes in enzyme properties were again traced to phosphorylation of the enzyme (Whitwam and Storey, 1991). Glycolysis and the pentose phosphate cycle are two of the main pathways competing for G6P in cells and estivationresponsive changes in the properties of their primary regulatory enzymes (PFK and G6PDH) suggest that carbohydrate flux through the pentose phosphate cycle may be relatively enhanced during estivation compared with carbohydrate flow through glycolysis. Citrate inhibition of both enzymes was also interesting; the high phosphate, estivating form of both G6PDH and PFK showed stronger inhibition by Mg.citrate (Table 1; Whitwam and Storey, 1991). Citrate accumulation typically signals high rates of lipid oxidation and provides feedback inhibition of PFK to spare carbohydrate use (for energy production or for lipid biosynthesis) under these circumstances. Citrate inhibition of G6PDH could similarly signal that NADPH supply for lipid synthesis is not needed and stronger citrate inhibition of the estivating form of the enzyme is consistent with the net catabolic state of the animals; biosynthetic processes are strongly suppressed during hypometabolism (Storey and Storey, 2004).

G6PDH from active and estivating snails also showed significantly different 
activation energies and differed in the extent of urea-dependent protein unfolding as evidenced both by urea inhibition of activity and susceptibility to thermolysin treatment. These differences all argue for a difference in protein conformation between active and estivating states which undoubtedly derives from differences in the amount of covalently bound phosphate on the enzyme in the two states. Both the $C_{m}$ and the $I_{50}$ value for urea were significantly higher for the peak II (phosphorylated) enzyme indicating a more stable conformation compared with the peak I form. Although this result derives from physical differences in the phosphorylation state of the protein, it may also have some physiological relevance. Urea is one of the nitrogenous end products that accumulates in snail tissues during estivation (Rees and Hand, 1993; Athawale and Reddy, 2002) and estivation is also associated with a progressive dehydration of tissues which results in elevated ionic strength and osmolality of body fluids. Thus, an enzyme form that is less sensitive to the denaturing effects of urea would be better suited for function under the cytoplasmic conditions that prevail during long term estivation.

Analysis of the effects of protein kinases and protein phosphatases on snail G6PDH were consistent with the identification of the peak I enzyme that dominates in active snails as the dephosphorylated (or low phosphate) form and the peak II enzyme as the phosphorylated (or high phosphate) form. Interestingly, the phosphorylated (estivating) form of hepatopancreas G6PDH seems to be the more active form $\left(\mathrm{V}_{\max }\right.$ is higher and $\mathrm{K}_{\mathrm{m}} \mathrm{G6P}$ lower than the dephosphorylated form) whereas studies of mammalian G6PDH have shown that PKA-mediated phosphorylation inhibits G6PDH activity (Costa Rosa et al., 1995; Zhang et al., 2000; Xu et al., 2005). The incubation studies indicated that both PKA and PKG could phosphorylate hepatopancreas G6PDH 
and mimic the effects of estivation on G6PDH maximal activity and its elution profile off DEAE Sephadex (Figure 3.3 and 3.4). Stimulation of other protein kinases (PKC, CaMK, AMPK) was ineffective. One or both of these kinases could mediate the estivationinduced response in vivo. Phosphorylation of PFK and pyruvate kinase in hepatopancreas extracts was also stimulated by incubation with Mg.ATP plus the second messengers of PKA, PKG and PKC (Whitwam and Storey, 1990, 1991). However, another study showed that changes in PKA activity and levels of cAMP and inositol 1,4,5 trisphosphate in O. lactea hepatopancreas were not consistent with either PKA or PKC being the kinases involved in mediating estivation-induced phosphorylation of pyruvate kinase (Brooks and Storey, 1994). Indeed, PKG has been shown to catalyze the phosphorylation of PFK and pyruvate kinase from marine mollusks during anoxia-induced metabolic rate depression (Brooks and Storey, 1990, 1997). The strong response by O. lactea G6PDH to incubation with cGMP - a conversion of $100 \%$ of activity to the phosphorylated peak II form (Figure 3.4) - implies that PKG may similarly be the protein kinase responsible for estivation-induced enzyme phosphorylation in land snails.

Incubation with AP fully converted hepatopancreas G6PDH to the peak I form, confirming that this peak contained the dephosphorylated enzyme. Dephosphorylation of G6PDH was also evident in incubations that stimulated endogenous i) total serine/threonine phosphatase activity; ii) PP1 activity; or iii) PP1 and PP2A activity. These three conditions all have PP1 in common and this suggests that PP1 may be the endogenous phosphatase responsible for G6PDH dephosphorylation during the arousal of snails out of estivation. 
Estivation in $O$. lactea includes oxidative stress. Although net oxygen consumption is reduced in estivating O. lactea to $9-28 \%$ of that in active snails (Herreid, 1977; Barnhart and McMahon, 1987), the animals must cope with irregular rapid increases in oxygen concentration at intervals during dormancy. The pneumostome, the specialized orifice leading to the lung, only opens intermittently during estivation for 2-3 short breathing periods per hour (Barnhart and McMahon, 1988). Oxygen uptake can increase 5-fold during these brief periods where the snail hyperventilates and releases $\mathrm{CO}_{2}$ (Barnhart and McMahon, 1987) and brief bursts of oxyradical generation can be associated with this pattern of discontinuous oxygen consumption. Furthermore, a burst of reactive oxygen species (ROS) generation accompanies arousal from estivation; this has been confirmed from measurements of the levels of lipid peroxidation products which rise rapidly to peak within the first few minutes of arousal (Hermes-Lima and Storey, 1995). To deal with oxidative stress during estivation, a variety of antioxidant mechanisms are enhanced during estivation in O. lactea (Hermes-Lima and Storey, 1995; Hermes-Lima et al., 1998). Activities of catalase, superoxide dismutase, glutathione peroxidase and glutathione-S-transferase were generally elevated in hepatopancreas and other tissues during estivation (Storey, 2002). Similarly, glutathione peroxidase activity increased by $4-5$ fold in tissues of estivating $H$. aspersa (Ramos-Vasconcelos and Hermes-Lima, 2003). Glutathione peroxidase and glutathione-S-transferase use reduced glutathione as their substrate and reduced glutathione is supplied by the NADPHdependent glutathione reductase reaction. NADPH is also used to regenerate reduced thioredoxin for peroxidiredoxin-mediated antioxidant activity (Das and White, 2002) and provides the reducing power for the detoxification and xenobiotic transformation 
reactions catalyzed by the cytochrome P450 family of enzymes (Digiulio et al., 1989). Hence, NADPH supply is essential for antioxidant defense and the estivation-responsive changes to G6PDH, the rate-limiting reaction in the pentose phosphate pathway that supplies the bulk of cellular NADPH, would enhance G6PDH function in this critical supporting role in antioxidant defense. Notably, G6PDH activity is elevated in a number of systems, ranging from yeast to humans, in response to oxidative stress (Slekar et al., 1996; Ursini et al., 1997; Larini et al., 2004) whereas inhibited and/or reduced G6PDH activity has been correlated with reduced antioxidant defense capacities, ROS-related cellular damage, and ROS-induced cell death (Tian et al., 1999; Sailaja et al., 2003, Kimura et al., 2004).

In summary, the present study shows that G6PDH from O. lactea hepatopancreas is a likely phosphoprotein and that entry into the hypometabolic state of estivation results in a strong increase in the fraction of phosphorylated G6PDH. The properties of phosphoG6PDH are consistent with a more active enzyme which may favour enhanced carbon flow through the pentose phosphate cycle during estivation to sustain NADPH production for antioxidant defense. The data provide the first demonstration of coordinated regulation of the pentose phosphate cycle between active and hypometabolic states and implicate PKG and PP1 as the protein kinase and phosphatase activities responsible for G6PDH regulation. 


\section{CHAPTER 4 \\ Purification and characterization of type-1 protein phosphatase activity in the estivating land snail Otala lactea}




\section{Introduction}

The transition into a hypometabolic state requires coordinated suppression of the rates of both energy-consuming and energy-producing pathways as well as a reorganization of the priorities for energy use during dormancy. A major point of regulation of this process is control over enzymes that are rate-limiting in their pathways. A regulatory mechanism that is powerful, rapidly reversible, and energetically efficient (ie. does not require de novo protein synthesis) is reversible protein phosphorylation and, indeed, this mechanism appears to be a major factor in transitions to and from hypometabolic states across phylogeny (Storey, 2001). The covalent binding of phosphate groups catalyzed by protein kinases or their removal by protein phosphatases can have immediate, dramatic effects on enzyme activity and properties, and reversible protein phosphorylation has proven to be an important mechanism regulating transitions between active and estivating states in $O$. lactea in previous studies (reviewed in Chapter 1). Furthermore, the results present in Chapters 2 and 3 of this thesis link protein phosphorylation to regulating the decrease in $\mathrm{Na}^{+} / \mathrm{K}^{+}$-ATPase activity and the increase in G6PDH activity during estivation. Thus, given the range of enzymes that are modified by reversible phosphorylation during estivation, it is clear that protein kinases and protein phosphatases must play a regulatory role in estivation. The studies in the present chapter focus on protein phosphatase 1 .

Activity of protein phosphatase 1 (PP1) is classically defined as being ionindependent and sensitive to inhibition by okadaic acid and physiological proteins designated inhibitor-1 and inhibitor-2. PP1 is known for its role in dephosphorylating the $\beta$-subunit of glycogen phosphorylase kinase and it is retained by heparin affinity 
columns; these traits distinguish type-1 phosphatases from enzymes in the type-2 subclass (Cohen, 1989). PP1 has a wide range of physiological roles and substrates (Cohen, 1985). The enzyme generally features a 33-40 kDa catalytic subunit (PP1c) that forms a complex with several types of regulatory proteins that modulate phosphatase activity and target PP1c to specific subcellular locations.

Roles for PP1 have been defined in several forms of hypometabolism including cold-hardy insects (Hayakawa and Chino, 1985; Pfister and Storey, 2002; Pfister and Storey, 2006a, 2006b), anoxia-tolerant turtles (Mehrani and Storey, 1995a), and freezetolerant wood frogs (MacDonald and Storey, 2002). PP1 has also been studied to some extent in estivating toads (Cowan et al., 2000) and in mollusks that are tolerant of anoxia (Cowan and Storey, 2001). This chapter examines type-1 phosphatase in O. lactea to determine if the enzyme is differentially regulated during estivation and might, therefore, contribute to the enzymatic control of enzymes during entry into or exit from dormancy.

\section{Methods and Materials.}

\section{Animals and Chemicals.}

Details of animal holding, experimentation and sampling are as described in Chapter 2. Phosphatase inhibitors were purchased from Calbiochem (La Jolla, CA, USA), peptide substrates were synthesized at Queen's University (Kingston, ON, Canada), centrifugal concentrating devices were purchased from Pall Life Sciences (Ann Arbor, MI, USA), and microcystin-agarose ( $75 \mu \mathrm{g}$ microcystin per $0.5 \mathrm{~mL}$ of matrix) was purchased from Upstate Biotechnology Inc (Lake Placid, NY). All other chemicals were obtained from Sigma (St. Louis, MO, USA). 


\section{Sample preparation.}

Frozen tissue samples were generally homogenized 1:5 (w/v) in cold $\left(4^{\circ} \mathrm{C}\right)$ buffer A containing $50 \mathrm{mM}$ imidazole, pH 7.5, $10 \%$ v:v glycerol, 2 mM EDTA, 2 mM EGTA, and $10 \mathrm{mM}$ 2-mercaptoethanol using a Polytron PT1000 homogenizer (Brinkmann Instruments, Rexdale, ON). A few crystals of phenylmethylsulfonyl fluoride and 1:1000 v:v Protease Inhibitor Cocktail (Sigma 8340) were added at the time of homogenization. Homogenates were centrifuged at $10,000 \mathrm{~g}$ for 20 minutes at $4^{\circ} \mathrm{C}$ and the supernatant was removed and either assayed immediately (crude extract activity) or subjected to further purification steps. PP1 activity assayed in crude extracts measures functional type-1 activity available to the animal at physiological concentrations of modulators and other factors (Toth et al., 1988).

\section{Removal of regulatory subunits.}

Crude extracts were subjected to treatments at $22^{\circ} \mathrm{C}$ that have been established as methods that could remove potential inhibitory regulatory subunits (Brandt et al., 1974; Dickey-Dunkirk et al., 1985): precipitation with 95\% ethanol (5:1 v:v) for $1 \mathrm{~h}$, precipitation with $2 \mathrm{M}\left(\mathrm{NH}_{4}\right)_{2} \mathrm{SO}_{4}(25 \%$ saturation; added $1: 1 \mathrm{v} / \mathrm{v})$ for $1 \mathrm{~h}$, or treatment with $1 \mathrm{mg} / \mathrm{mL}$ trypsin and $1 \mathrm{mM} \mathrm{MnCl}$ for 10 minutes. After the ethanol treatment, the sample was centrifuged for 5 minutes at $10,000 \mathrm{~g}$, ethanol was removed and the pellet was resuspended in the original volume of buffer $\mathrm{A}$. After the $\left(\mathrm{NH}_{4}\right)_{2} \mathrm{SO}_{4}$ treatment, the sample was centrifuged for 5 minutes at $10,000 g$; the supernatant was poured off and precipitated protein was resuspended in the original volume of buffer A. After limited 
trypsin digestion, trypsin activity was stopped by adding soybean trypsin inhibitor to a final concentration of $10 \mathrm{mg} / \mathrm{mL}$. Untreated, ethanol-treated, $\left(\mathrm{NH}_{4}\right)_{2} \mathrm{SO}_{4}$-treated, and trypsin-treated extracts were desalted by passage through Sephadex G-25 columns (100 $\mu \mathrm{L}$ of extract on $1 \mathrm{~mL}$ of columns) equilibrated in buffer $\mathrm{A}$; treatments that increased recoverable PP1 type activity were then included in the following purification protocol.

\section{Purification of type-1 phosphatase activity from foot muscle.}

PP1 activity was purified using modifications of established ion exchange, gel filtration, and affinity chromatography methods for PP1 (Erdodi et al., 1985; Klumpp et al., 1990; Moorhead et al., 1995; Pfister and Storey, 2002). Methodology was basically the same for active and estivating snails. Trypsin-treated crude extract $(2 \mathrm{~mL})$ was added to an $8 \mathrm{~cm} \times 1.8 \mathrm{~cm}(\mathrm{~h} \mathrm{x} \mathrm{d})$ DEAE-G25 Sephadex (equilibrated in buffer A, pH 7.5) and washed with $60 \mathrm{~mL}$ of buffer $\mathrm{A}$ to remove unbound protein. The column was then developed with a 0-1 M NaCl gradient in buffer A. Fractions were collected $(\sim 200 \mu \mathrm{L}, 12$ drops) in glass test tubes using a Gilson MicroFractionator (Middleton, WI, USA).

Fractions that tested positive for phosphatase activity were pooled and loaded onto a 9.0 x $1.0 \mathrm{~cm}$ column of heparin-Sepharose (equilibrated in buffer $\mathrm{A}, \mathrm{pH} 7.5$ ); $100 \%$ of PP1 activity was retained. The heparin-Sepharose column was washed with $10 \mathrm{~mL}$ of buffer A containing $0.1 \mathrm{M} \mathrm{NaCl}$ to remove unbound proteins and any type-2A phosphatases that might bind to the column (Klumpp et al., 1990), and then PP1 activity was recovered from the column using a $0.5 \mathrm{M} \mathrm{NaCl}$ bump in buffer A. Fractions $(200 \mu \mathrm{L})$ that contained type- 1 phosphatase activity were pooled and loaded onto a $90 \times 2.5 \mathrm{~cm}$ Sephacryl S-400 column that was previously equilibrated overnight with buffer B (buffer A plus $150 \mathrm{mM}$ 
$\mathrm{NaCl}, 20 \%$ glycerol, and $0.04 \% \mathrm{w}: \mathrm{v}$ sodium azide). The column was washed with buffer B and fractions ( $500 \mu \mathrm{L}, 28$ drops) that tested positive for PP1 activity were pooled and concentrated using Pall NanoSep centrifugal devices (MW cutoff $10 \mathrm{kDa}$ ). Aliquots (500 $\mu \mathrm{L}$ ) of pooled sample were added to NanoSep reservoirs and centrifuged at 14,000 x $\mathrm{g}$ for 6 minutes (per manufacturer's directions) to concentrate them 10-fold (down to $\sim 50$ $\mu \mathrm{L}$ per NanoSep tube). PP1 activity in the pooled, concentrated sample was then further purified using microcystin affinity chromatography. Approximately $0.7 \mathrm{~mL}$ of sample was gently mixed in a small, capped column with $\sim 3 \mathrm{~mL}$ of microcystin-agarose suspended in buffer $\mathrm{C}$ (buffer $\mathrm{A}+0.5 \mathrm{M} \mathrm{NaCl}$ ) for 30 minutes at $4^{\circ} \mathrm{C}$. The column was then drained, and the suspension was settled into a column matrix $(2.0 \times 1.0 \mathrm{~cm})$ that was washed with five volumes of buffer $\mathrm{C}$ to remove unbound protein. PP1 was then eluted using a bump of buffer $\mathrm{C}$ containing $3 \mathrm{M}$ sodium thiocyanate $(\mathrm{NaSCN})$. Fractions containing activity were pooled and used for kinetic analysis.

In addition to the use of gel filtration S-400 chromatography for the purification of PP1 activity, gel filtration was also used to estimate what protein sizes were correlated with phosphatase type- 1 activity from crude extracts that had not been treated with trypsin or ethanol. Selected kinetic parameters were also determined for different protein sizes associated with PP1 type activity.

\section{SDS PAGE to assess purification and molecular weight}

Samples from various purification steps were subjected to SDS-PAGE as described in Chapter 2. After electrophoresis, gels were fixed for $1 \mathrm{~h}$ in $10 \% \mathrm{v}: \mathrm{v}$ acetic acid and $25 \%$ v:v methanol, stained for 20 minutes with $25 \%$ w:v Coomassie Brilliant 
Blue in 7.5\% v:v acetic acid and 50\% v:v methanol, and then destained overnight in fixing solution. Gels were then rinsed and stored in water before an image was captured with the ChemiGenius bio-imaging system (Syngene, Frederick, MD).

\section{Type-1 phosphatase assay.}

Assays were generally initiated by addition of $25 \mu \mathrm{L}$ of enzyme extract to a final assay volume of $250 \mu \mathrm{L}$ in an Eppendorf tube. For phosphatase activity eluted from columns, assays were initiated by adding $100 \mu \mathrm{L}$ of enzyme sample to $500 \mu \mathrm{L}$ final volume. Before all assays, enzyme samples (from crude extracts or from column fractions) were desalted by passing through a Sephadex G-25 column (100 $\mu$ L of extract/1 mL of column) that was equilibrated in buffer A. Casein substrate solution was also desalted in the same manner to remove inorganic phosphate that otherwise would increase background (Fathi et al., 2002).

Preliminary studies detected type-1 activity, and further studies were performed, using the following three phosphorylated substrates: kemptide [LRRApSLG], phosphorylase $\underline{\text { a }}$, and p-nitrophenyl phosphate (P-NPP). Negligible activity was observed in preliminary studies towards casein, the PP2A/C specific peptide RRApTVA, and the peptide KRpYIRR. PP1 activity was defined as phosphatase activity towards its substrate that was sensitive to inhibition by $1 \mu \mathrm{M}$ okadaic acid. Parallel reactions were run with 5 nM okadaic acid (this concentration abolishes any PP2A activity, but PP1 is unaffected) and $1 \mu \mathrm{M}$ okadaic acid (abolishes $100 \%$ of type- 1 activity); the difference in activity was attributed to type- 1 protein phosphatase. Assay conditions included $200 \mu \mathrm{M}$ substrate, 25 mM imidazole, $\mathrm{pH} 7.2,0.1 \%$ B-mercaptoethanol, 2 mM EDTA, $2 \mathrm{mM}$ EGTA, and $1 \mathrm{mM}$ 
$\mathrm{Na}_{3} \mathrm{VO}_{4}$. Reaction time was 15 minutes.

The ammonium molybdate/malachite green system of detection.

Type-1 phosphatase activity was detected using a modified nonradioactive method that is as sensitive as, and yields comparable results to, radioactive PP1 assays involving ${ }^{32} \mathrm{P}$-labeled substrates (Geladopolous et al., 1991). Phosphatase activity was determined as the amount of free phosphate produced which is detected using the ammonium molybdate/malachite green phosphate complexing dye as previously described (Pfister and Storey, 2006a; 2006b). Reagent was prepared and assays were performed as described in Chapter 2.

Reactions were stopped by addition of an aliquot of assay mixture $(25 \mu \mathrm{L}$ for crude extract or $50-100 \mu \mathrm{L}$ for column fractions) to a detection tube containing $200 \mu \mathrm{L}$ dye reagent and $\mathrm{dd}_{2} \mathrm{O}$ to a final volume of $1 \mathrm{~mL}$. After colour development for $15 \mathrm{~min}$, aliquots were transferred to microplates and absorbance at $595 \mathrm{~nm}$ was measured using a MR5000 microplate reader from Dynatech Laboratories (Chantilly, VA, USA) and Biolinx 2.0 software (Brockville, ON). Phosphate production was determined by comparison with a $\mathrm{KH}_{2} \mathrm{PO}_{4}$ standard curve. All samples were measured in triplicate and averaged. Activity was reported as nmol phosphate released $/ \mathrm{min} / \mathrm{mg}$ soluble protein $(\mathrm{mU} / \mathrm{mg})$. Protein concentration was quantified using a bovine serum albumin standard curve and the Coomassie Blue dye binding method with prepared protein reagent from BioRad (Hercules, CA, USA). Kinetic constants were determined using the Kinetics 3.51 program (Brooks, 1992) and significance testing done using Mynova, Version 2.3. 


\section{Results}

\section{Optimization of experimental conditions}

Initial trials optimized homogenization and assay conditions that yielded maximal recoverable type- 1 phosphatase activity, as well as linearity with respect to assay time and volume of enzyme extract used, as described in Chapter 2.

Stripping of regulatory subunits improves yield of PP1 type activities in crude extracts

Incubation of crude extracts of either $O$. lactea foot muscle or hepatopancreas with ethanol, ammonium sulphate, or trypsin generally increased the measurable activity of PP1 towards the substrate Kemptide (Figure 4.1). These treatments led to a $\sim 2.0$-fold increase in recoverable PP1 activity in foot muscle extracts from active snails and a 3.0fold increase in PP1 activity in extracts from estivating snails (Figure 4.1A). In hepatopancreas extracts, treatment with trypsin raised PP1 activity by 1.3 -fold in extracts from active snails, and incubations with ethanol, ammonium sulphate, and trypsin increased recoverable PP1 activity by 1.9-, 1.8-, and 2.3-fold, respectively, in estivating snails (Figure 4.1B). Thus, stripping treatments generally elevated type-1 phosphatase activity from both active and estivated snails to similar levels in both tissues. Hence, treatment with either trypsin or ethanol was included in subsequent PP1 purification procedures.

\section{Characterization of PP1-type activity in crude extracts.}

Maximal PP1 activity was generally decreased during estivation in both foot muscle and hepatopancreas crude extracts. In foot muscle extracts from estivating snails, PP1 $V_{\max }$ was decreased to $65 \%$ and $61 \%$ of that in active snails when tested with 
Kemptide and phosphorylase a, respectively, as the substrate (Figure 4.2A). PP1 activity in hepatopancreas extracts from estivated snails behaved similarly with activities that were $65 \%$ with Kemptide and $57 \%$ with phosphorylase a of the corresponding values in active snails (Figure 4.2B). Recoverable activity towards P-NPP as a substrate was substantially reduced in both tissues relative to the activities with the other two substrates, and no change in P-NPP dephosphorylation rate was detected between the active and estivated conditions. Hence, subsequent kinetic characterization experiments used only Kemptide or phosphorylase a as substrates. Table 4.1 shows that in addition to changes in $\mathrm{V}_{\max }$, estivation also had marked effects on other properties of PP1 including substrate affinities and responses to inhibitors. Substrate affinities were significantly reduced for PP1 from estivating snails as compared with active animals; the $\mathrm{K}_{\mathrm{m}}$ values for Kemptide and phosphorylase a were 1.9- and 1.7-fold higher, respectively, in foot muscle extracts from estivating animals and the $\mathrm{K}_{\mathrm{m}}$ for phosphorylase a of hepatopancreas PP1 was 1.6-fold higher than the active value.

PP1 responses to inhibitors also changed in crude extracts in the estivated condition. PP1 sensitivity to okadaic acid was higher during estivation, with $\mathrm{I}_{50}$ values reduced to $73 \%$ and $64 \%$ of the respective values in active snail foot muscle and hepatopancreas (Table 4.1). The okadaic acid inhibition profile of foot muscle PP1 activity is also displayed in Figure 4.3; a similar pattern of inhibition was seen in both active and estivated states but with stronger okadaic acid inhibition overall for the enzyme from estivated snails. PP1 activity was also sensitive to inhibition by the adenylates, ADP and AMP, at micromolar concentrations that would be physiologically relevant. In all cases, PP1 from estivating snails showed reduced sensitivity to ADP and 
AMP as compared with the enzyme from active snails, with $\sim 1.5$-fold increases in the $\mathrm{I}_{50}$ values for $\mathrm{AMP}$ and $~ 1.4$-fold increases in $\mathrm{I}_{50} \mathrm{ADP}$ in both tissues. The $\mathrm{I}_{50} \mathrm{NaCl}$ of the hepatopancreas enzyme also increased by 1.5 -fold during estivation (Table 4.1 ).

\section{Purification and characterization of type-1 protein phosphatase from foot muscle.}

The procedure for purification of PP1 from foot muscle of active snails is detailed in Table 4.2. The enzyme was purified 193-fold with a combination of four different chromatography steps that have been applied previously for PP1 purification. An $11 \%$ yield was achieved with a final specific activity of $197 \mathrm{mU} / \mathrm{mg}$ protein. Only one sharp peak of PP1 activity eluted from the Sephacryl-S400 column and that was associated with a protein size of $38 \pm 2 \mathrm{kDa}$ (mean \pm S.E.M., $\mathrm{n}=3$ independent determinations). A representative SDS-PAGE gel from one of the purification trials is shown in Figure 4.4. After the gel filtration step the pooled peak fractions featured two bands, at $45 \mathrm{kDa}$ and $39 \mathrm{kDa}$, but after the final microcystin chromatography the purified enzyme preparation showed only one band at $39 \mathrm{kDa}$. Comparable molecular weight values were associated with the purification of foot muscle PP1 purification from estivating snails (data not shown). Kinetic properties of the purified enzymes from active and estivated foot muscle were characterized (Table 4.3). Although the parameters tested all differed between active and estivated states for the crude enzyme (except for $I_{50}$ urea) (Table 4.1), there were no significant differences in these properties between the two states when the purified enzymes were examined.

Characterization of different gel filtration peaks of type-1 phosphatase activity. 
When crude extracts of snail tissues were applied to Sephacryl S-400 gel filtration columns (without prior ethanol or trypsin treatments to remove regulatory subunits), PP1 activity was consistently eluted in four peaks that are evident in the representative elution profiles shown in Figure 4.5A for active and Figure 4.5B for estivating foot muscle.

Peaks I, II, III, and IV were associated with protein sizes of $257 \pm 8 \mathrm{kDa}, 135 \pm 4 \mathrm{kDa}, 76$ $\pm 2 \mathrm{kDa}$, and $40 \pm 2 \mathrm{kDa}$, respectively (mean \pm S.E.M., $\mathrm{n}=3$ independent determinations on separate preparations of active snail foot muscle). SDS-PAGE separation of each of the pooled peaks determined that peaks III and IV from gel filtration were associated with one sharp band appearing in each fraction at $75 \mathrm{kDa}$ and $40 \mathrm{kDa}$, respectively, corresponding with the sizes calculated for those peaks from gel filtration.

Electrophoretic analysis of Peak I showed several weak bands, including two weak bands $>200 \mathrm{kDa}$, and several weak, faint bands between $60 \mathrm{kDa}$ and $100 \mathrm{kDa}$ (Figure 4.4). Peak II from gel filtration did not show bands in preliminary SDS-PAGE runs, and was omitted from the representative gel.

A consistent and reproducible shift in the distribution of PP1 activity between the four peaks was observed when the elution profiles for PP1 from active and estivating snails were compared. The percentage of total PP1 activity that was present in peaks I, II, III, and IV was $30 \pm 4 \%, 14 \pm 3 \%, 20 \pm 3 \%$, and $35 \pm 5 \%$, respectively, in extracts from active foot muscle, but shifted to $22 \pm 2 \%, 16 \pm 5 \%, 34 \pm 4 \%$, and $28 \pm 5 \%$ in extracts from estivating foot muscle (means \pm S.E.M., $n=3$ independent determinations). Thus, in estivation, there was a significant decrease in the proportion of PP1 type activity associated with peak I, and a significant increase in the proportion of PP1 activity associated with peak III, relative to the active condition ( $\mathrm{P}<0.05$, Student's t-test). 
Selected kinetic parameters were determined for the isolated gel filtration peaks of active foot muscle type-1 phosphatase activity (Table 4.4). Peak III PP1 activity (76 $\mathrm{kDa})$ differed in affinity for phosphorylase a from both peak I (257 kDa) and peak IV (40 $\mathrm{kDa}$ ) with 3.7- and 2.2-fold higher $\mathrm{K}_{\mathrm{m}}$ values, respectively. Type-1 phosphatase activity associated with Peak III also featured decreased affinity for Kemptide (3.0-fold increase in $\mathrm{K}_{\mathrm{m}}$ value) and increased sensitivity to okadaic acid inhibition (69\% decrease in $\mathrm{I}_{50}$ ), relative to phosphatase activity characterized from Peak I. 
Table 4.1. Kinetic parameters for PP1-type activity in crude extracts from foot muscle and hepatopancreas of active and $10 \mathrm{~d}$ estivated $O$. lactea.

\begin{tabular}{lllll} 
& \multicolumn{2}{c}{ Foot muscle } & \multicolumn{2}{c}{ Hepatopancreas } \\
& Active & Estivated & Active & Estivated \\
\hline $\begin{array}{l}\mathrm{V}_{\max }(\mathrm{mU} / \mathrm{mg} \\
\text { soluble protein) }\end{array}$ & $1.33 \pm 0.16$ & $0.81 \pm 0.09^{*}$ & $1.80 \pm 0.18$ & $1.02 \pm 0.18^{*}$ \\
$\mathrm{~K}_{\mathrm{m}}$ Kemptide $(\mu \mathrm{M})$ & $16.8 \pm 3.3$ & $31.6 \pm 2.9^{*}$ & $27.0 \pm 3.6$ & $34.4 \pm 6.0$ \\
$\mathrm{~K}_{\mathrm{m}}$ phosphorylase $\underline{\mathrm{a}}$ & $19.6 \pm 4.1$ & $33.8 \pm 5.3^{*}$ & $18.6 \pm 2.9$ & $29.4 \pm 3.2^{*}$ \\
$(\mu \mathrm{M})$ & & & & \\
$\mathrm{I}_{50}$ okadaic acid & $99.0 \pm 6.4$ & $72.7 \pm 4.3^{*}$ & $84.6 \pm 5.8$ & $54.2 \pm 6.8^{*}$ \\
$(\mathrm{nM})$ & & & & \\
$\mathrm{I}_{50} \mathrm{NaF}(\mathrm{mM})$ & $5.4 \pm 0.9$ & $7.3 \pm 2.9$ & $10.1 \pm 3.9$ & $8.3 \pm 2.4$ \\
$\mathrm{I}_{50} \mathrm{NH} \mathrm{Cl}(\mathrm{mM})$ & $22 \pm 4$ & $19 \pm 5$ & $29 \pm 4$ & $32 \pm 3$ \\
$\mathrm{I}_{50} \mathrm{AMP}(\mu \mathrm{M})$ & $65 \pm 8$ & $99 \pm 12^{*}$ & $119 \pm 19$ & $175 \pm 29^{*}$ \\
$\mathrm{I}_{50} \mathrm{ADP}(\mu \mathrm{M})$ & $73 \pm 9$ & $99 \pm 8^{*}$ & $101 \pm 13$ & $146 \pm 12^{*}$ \\
$\mathrm{I}_{50} \mathrm{NaCl}(\mathrm{mM})$ & $211 \pm 26$ & $187 \pm 29$ & $275 \pm 31$ & $415 \pm 43^{*}$ \\
$\mathrm{I}_{50} \mathrm{urea}(\mathrm{M})$ & $2.9 \pm 0.8$ & $3.6 \pm 0.4$ & $2.2 \pm 0.4$ & $2.5 \pm 0.3$ \\
\hline
\end{tabular}

Assays were conducted at $22^{\circ} \mathrm{C}$ and data are means \pm S.E.M. $\left(\mathrm{n}=3\right.$ for okadaic acid $\mathrm{I}_{50}$ values, $n=5 V_{\max }$ and $K_{m}$ values, $n=4$ for all other parameters). Kinetic determinations (except for determination of $\mathrm{K}_{\mathrm{m}}$ Kemptide) used phosphorylase $\underline{\mathbf{a}}$ as the substrate. $\mathrm{I}_{50}$ is the concentration of inhibitor that reduces enzyme activity by $50 \%$. Kinetic constants were determined under optimal assay conditions. Significance testing used the Student's t-test. *- Significantly different from the corresponding value for active snails, $\mathrm{P}<0.05$. 
Table 4.2. Purification of type-1 protein phosphatase activity from foot muscle of active O. lactea snails. Data is representative of three purification trials for the enzyme from active snails; similar results were obtained for purification of PP1-type activity from estivating snails (data not shown). Activity was assayed using Kemptide as the substrate.

\begin{tabular}{|c|c|c|c|c|c|}
\hline Purification steps & $\begin{array}{l}\text { Total } \\
\text { protein } \\
(\mathrm{mg})\end{array}$ & $\begin{array}{l}\text { Total } \\
\text { activity } \\
(\mathrm{mU})\end{array}$ & $\begin{array}{l}\text { Specific } \\
\text { activity } \\
(\mathrm{mU} / \mathrm{mg})\end{array}$ & $\begin{array}{l}\text { Purification } \\
\text { (fold) }\end{array}$ & $\begin{array}{l}\text { Yield } \\
(\%)\end{array}$ \\
\hline Crude extract & 129 & 132 & 1.02 & - & 100 \\
\hline Trypsin treatment & 75 & 165 & 2.20 & 2.16 & 125 \\
\hline $\begin{array}{r}\text { DEAE-G25 } \\
\text { Sephadex }\end{array}$ & 24 & 82 & 3.41 & 3.34 & 62 \\
\hline Heparin-Sepharose & 8.6 & 55 & 6.40 & 6.27 & 42 \\
\hline Sephacryl S-400 & 1.7 & 26 & 15.3 & 15.0 & 20 \\
\hline $\begin{array}{l}\text { NanoSep } \\
\text { concentration }\end{array}$ & 0.39 & 21 & 53.8 & 52.8 & 16 \\
\hline $\begin{array}{l}\text { Microcystin- } \\
\text { agarose }\end{array}$ & 0.071 & 14 & 197 & 193 & 11 \\
\hline
\end{tabular}


Table 4.3. Kinetic parameters for purified PP1-type activity from foot muscle of active and $10 \mathrm{~d}$ estivated $O$. lactea.

\begin{tabular}{lll}
\hline & $\begin{array}{l}\text { Active foot muscle, } \\
\text { Microcystin-purified }\end{array}$ & $\begin{array}{l}\text { Estivated foot muscle, } \\
\text { Microcystin-purified }\end{array}$ \\
\hline $\mathrm{V}_{\max }(\mathrm{mU} / \mathrm{mg}$ protein) & $215 \pm 21$ & $233 \pm 16$ \\
$\mathrm{~K}_{\mathrm{m}}$ Kemptide $(\mu \mathrm{M})$ & $15.2 \pm 3.1$ & $16.9 \pm 3.6$ \\
$\mathrm{~K}_{\mathrm{m}}$ phosphorylase $\underline{\mathrm{a}}(\mu \mathrm{M})$ & $12.2 \pm 2.9$ & $13.8 \pm 3.0$ \\
$\mathrm{I}_{50}$ okadaic acid $(\mathrm{nM})$ & $112 \pm 10$ & $99 \pm 6$ \\
$\mathrm{I}_{50} \mathrm{AMP}(\mu \mathrm{M})$ & $111 \pm 15$ & $108 \pm 9$ \\
$\mathrm{I}_{50} \mathrm{ADP}(\mu \mathrm{M})$ & $122 \pm 24$ & $138 \pm 31$ \\
$\mathrm{I}_{50}$ urea $(\mathrm{M})$ & $1.5 \pm 0.4$ & $1.2 \pm 0.2$ \\
\hline
\end{tabular}

Assays were conducted at $22^{\circ} \mathrm{C}$ using purified PP1 prepared as in Table 4.2 and phosphorylase a as the substrate (except for determination of $\mathrm{K}_{\mathrm{m}}$ Kemptide). Data are means \pm S.E.M. ( $n=3$ independent purification runs). Other information as in Table 4.1. 
Table 4.4. Kinetic parameters for active snail foot muscle PP1-type activity associated with different molecular weights recovered from Sephacryl S-400 gel filtration.

\begin{tabular}{lllll}
\hline & Peak I & Peak II & Peak III & Peak IV \\
& $257 \mathrm{kDa}$ & $135 \mathrm{kDa}$ & $76 \mathrm{kDa}$ & $40 \mathrm{kDa}$ \\
\hline $\begin{array}{l}\mathrm{K}_{\mathrm{m}} \text { phosphorylase a } \\
(\mu \mathrm{M})\end{array}$ & $13.7 \pm 2.6$ & $35.7 \pm 4.5$ & $50.3 \pm 8.1^{\mathrm{a}, \mathrm{b}}$ & $23.0 \pm 3.1$ \\
$\begin{array}{l}\mathrm{K}_{\mathrm{m}} \text { Kemptide } \\
(\mu \mathrm{M})\end{array}$ & $11.0 \pm 1.9$ & $25.3 \pm 5.5$ & $33.1 \pm 5.2^{\mathrm{a}}$ & $19.2 \pm 4.2$ \\
$\begin{array}{l}\mathrm{I}_{50} \text { okadaic acid } \\
(\mathrm{nM})\end{array}$ & $118 \pm 9$ & $80 \pm 8$ & $70 \pm 9^{\mathrm{a}}$ & $101 \pm 7$ \\
$\mathrm{I}_{50}$ urea $(\mathrm{M})$ & $3.9 \pm 0.6$ & $2.6 \pm 0.4$ & $1.9 \pm 0.5$ & $2.8 \pm 0.4$ \\
\hline
\end{tabular}

Fractions were pooled for each of the four peaks shown in Figure 4.5. Assays determining inhibition constants were conducted at $22^{\circ} \mathrm{C}$ using phosphorylase a as the substrate; data are means \pm S.E.M. $(n=3)$. Significant differences among the groups were determined using the Tukey's test. a - Significantly different from the corresponding value for peak $\mathrm{I}, \mathrm{P}<0.05 ; \mathrm{b}$ - significantly different from the corresponding peak IV value, $\mathrm{P}<0.05$. Other information as in Table 4.1. 
Figure 4.1. Recoverable PP-1 type activity from crude extracts of active and estivating $O$. lactea after different treatments to promote dissociation of regulatory subunits in (A) foot muscle and (B) hepatopancreas. Activity was measured at $22^{\circ} \mathrm{C}$ using phosphorylase a as the substrate under optimal assay conditions. Stripping conditions and optimal assay conditions are detailed in Materials and Methods. Data are means \pm SEM, $n=3$ independent determinations. a - Significantly different from the corresponding activity in the crude extract using the Student's t-test, $\mathrm{P}<0.05$; $\mathrm{b}$ - significantly different from enzyme activity in active snails under the same condition, $\mathrm{P}<0.05$. 


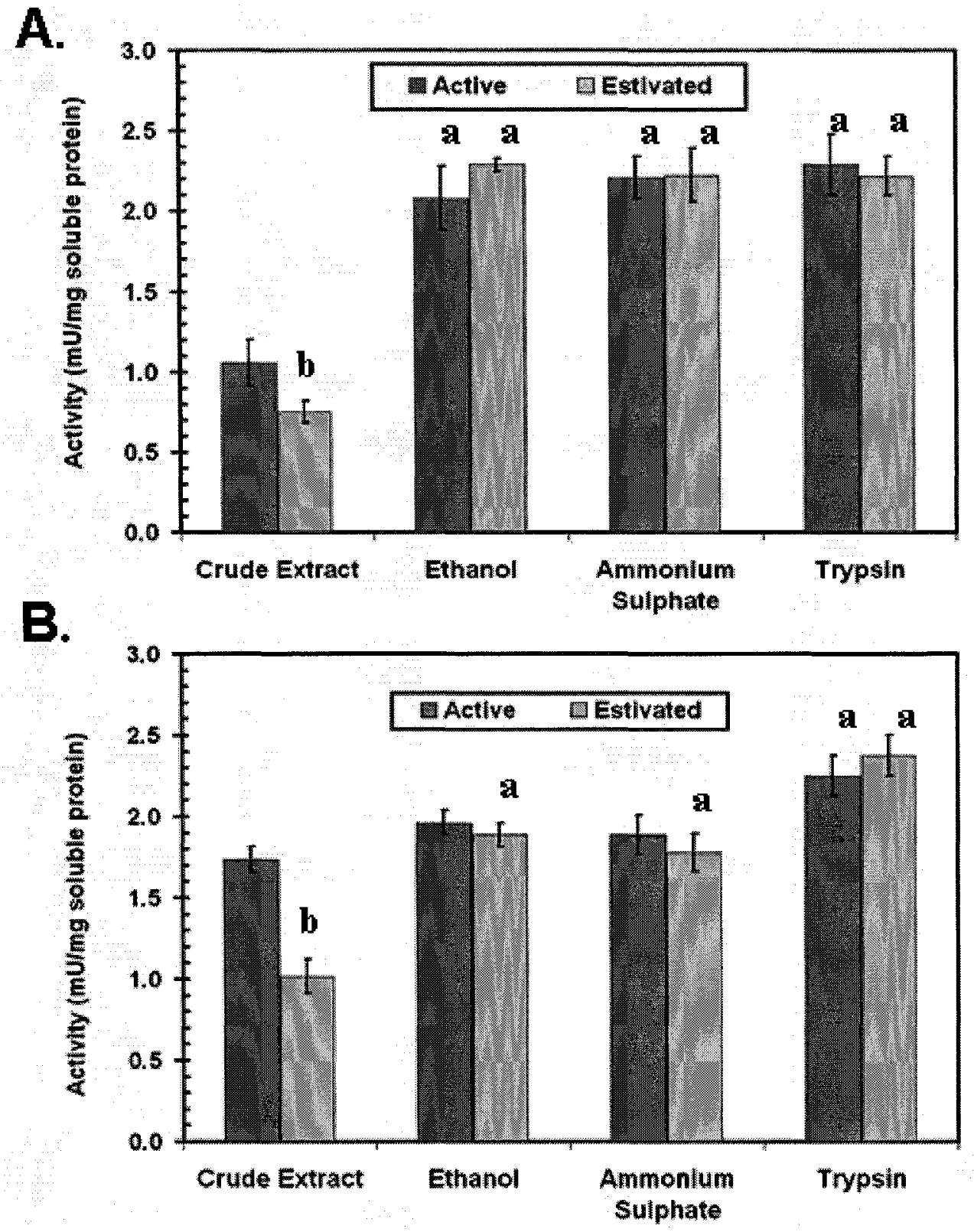


Figure 4.2. Type-1 phosphatase activity from crude extracts of $O$. lactea (A) foot muscle and (B) hepatopancreas measured with different substrates. Activity was measured under optimal $\mathrm{V}_{\max }$ conditions at $22^{\circ} \mathrm{C}$. Data are means \pm S.E.M, $\mathrm{n}=5$ independent determinations. a - Significantly different from the corresponding activity in extracts from active snails using the Student's t-test, $\mathrm{P}<0.05$. 
A.

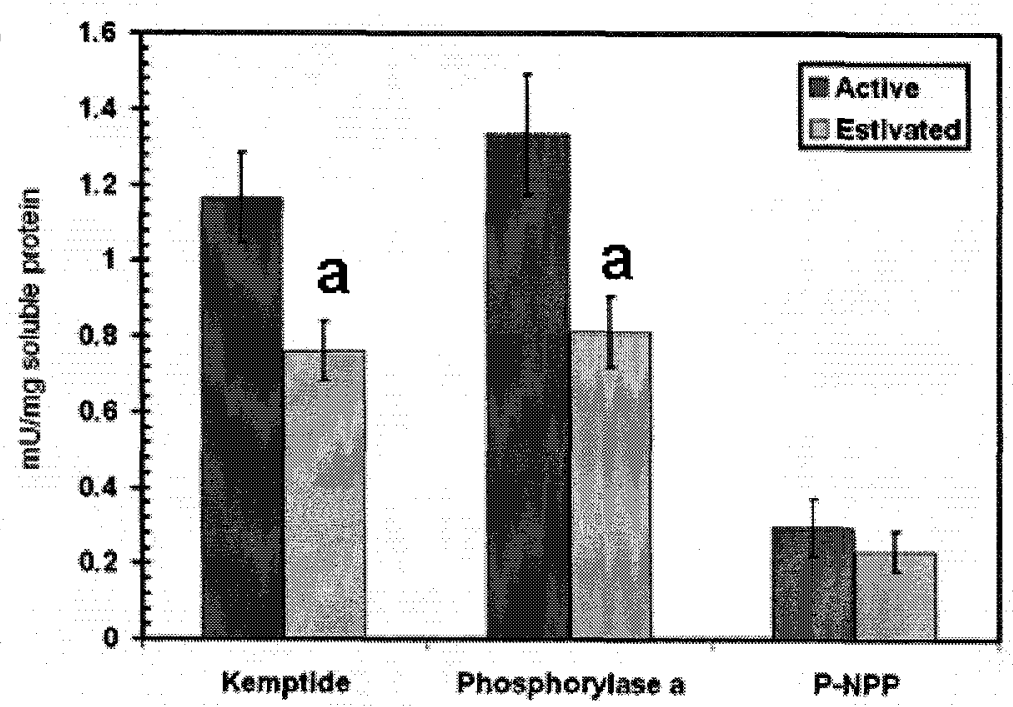

B.

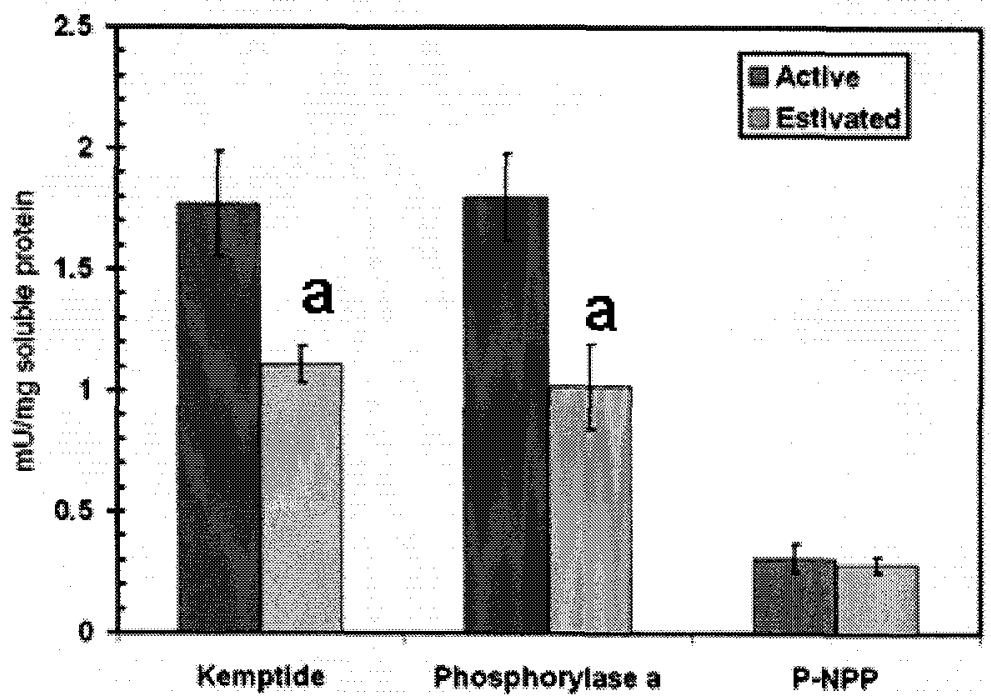


Figure 4.3. Type-1 phosphatase activity recovered from $O$. lactea foot muscle as a function of okadaic acid concentration, comparing the crude enzyme from active and estivating snails and the purified enzyme from active snails. Activity was measured at $22^{\circ} \mathrm{C}$ using phosphorylase a as the substrate under optimal assay conditions. Data are means \pm S.E.M, $\mathrm{n}=3$ independent determinations. PP1 activity purified from estivating foot muscle featured indistinguishable okadaic acid inhibition kinetics compared to PP1 activity purified from active snails, and was not plotted. 


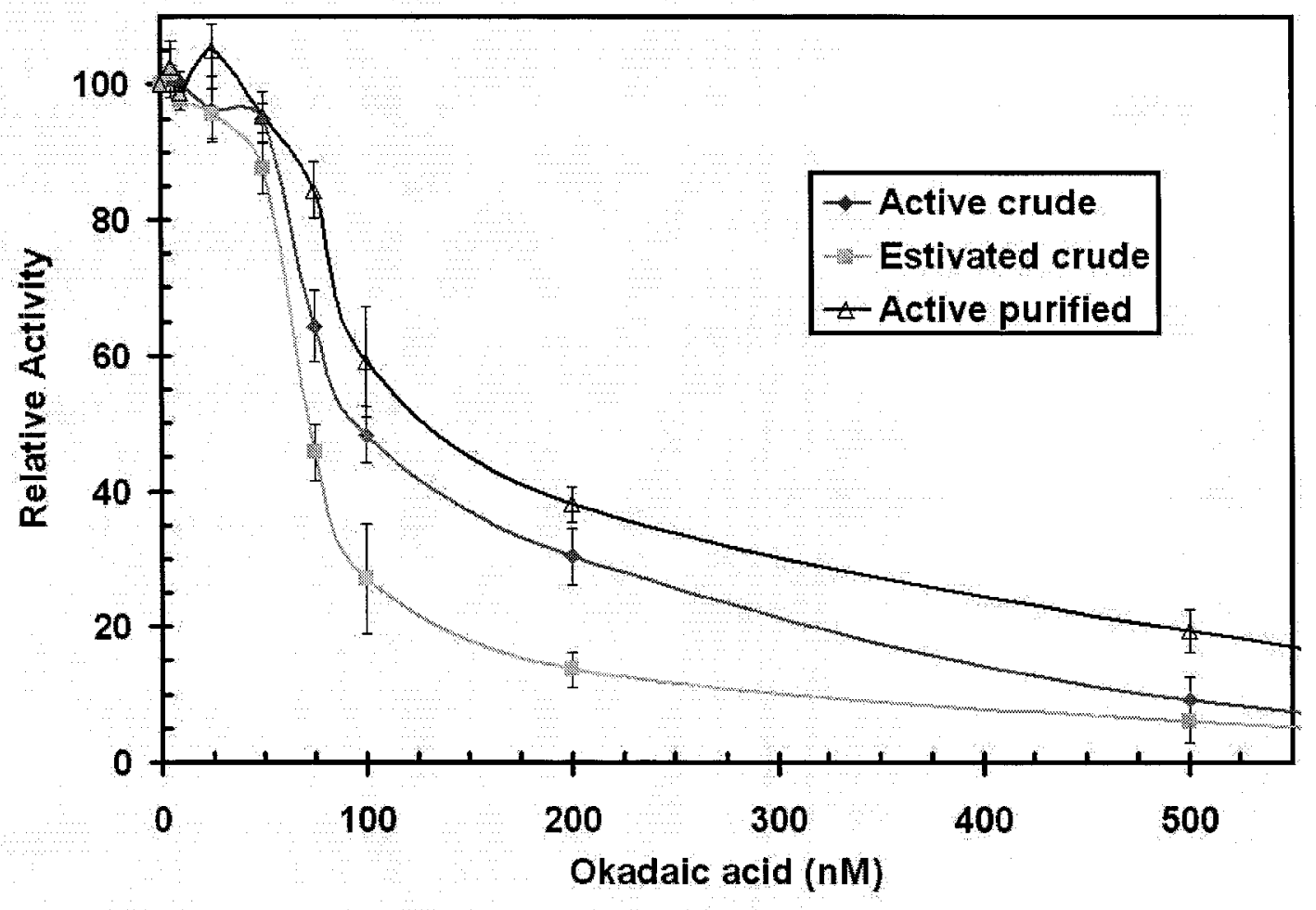


Figure 4.4. SDS-PAGE with Coomassie blue staining of samples taken at different steps in the analysis of PP1 from foot muscle of active O. lactea snails. Samples of $15 \mu \mathrm{L}$ were run in each lane. The purification of PP1, detailed in Table 4.2, is illustrated in lanes A to E for the different steps: (A) trypsin treatment of the crude extract, (B) DEAE-ion exchange, (C) heparin-Sepharose chromatography, (D) Sephacryl S-400 gel filtration, and (E) microcystin-agarose chromatography. Lanes F to I show an analysis of the peaks of PP1 activity recovered from gel filtration of untreated crude extracts of foot muscle (ie. no prior treatments to remove regulatory subunits) as shown in Figure 4.5. Lanes are: (F) untreated crude extract, (G) peak I, (H) peak III, (I) peak IV. Lane J shows Biorad Kaleidoscope molecular weight standards $(2 \mu \mathrm{L})$ : myosin, $201 \mathrm{kDa}, \boldsymbol{\beta}$-galactosidase, 134 $\mathrm{kDa}$, bovine serum albumin, $81 \mathrm{kDa}$, carbonic anhydrase, $42 \mathrm{kDa}$, soybean trypsin inhibitor, $32 \mathrm{kDa}$. 


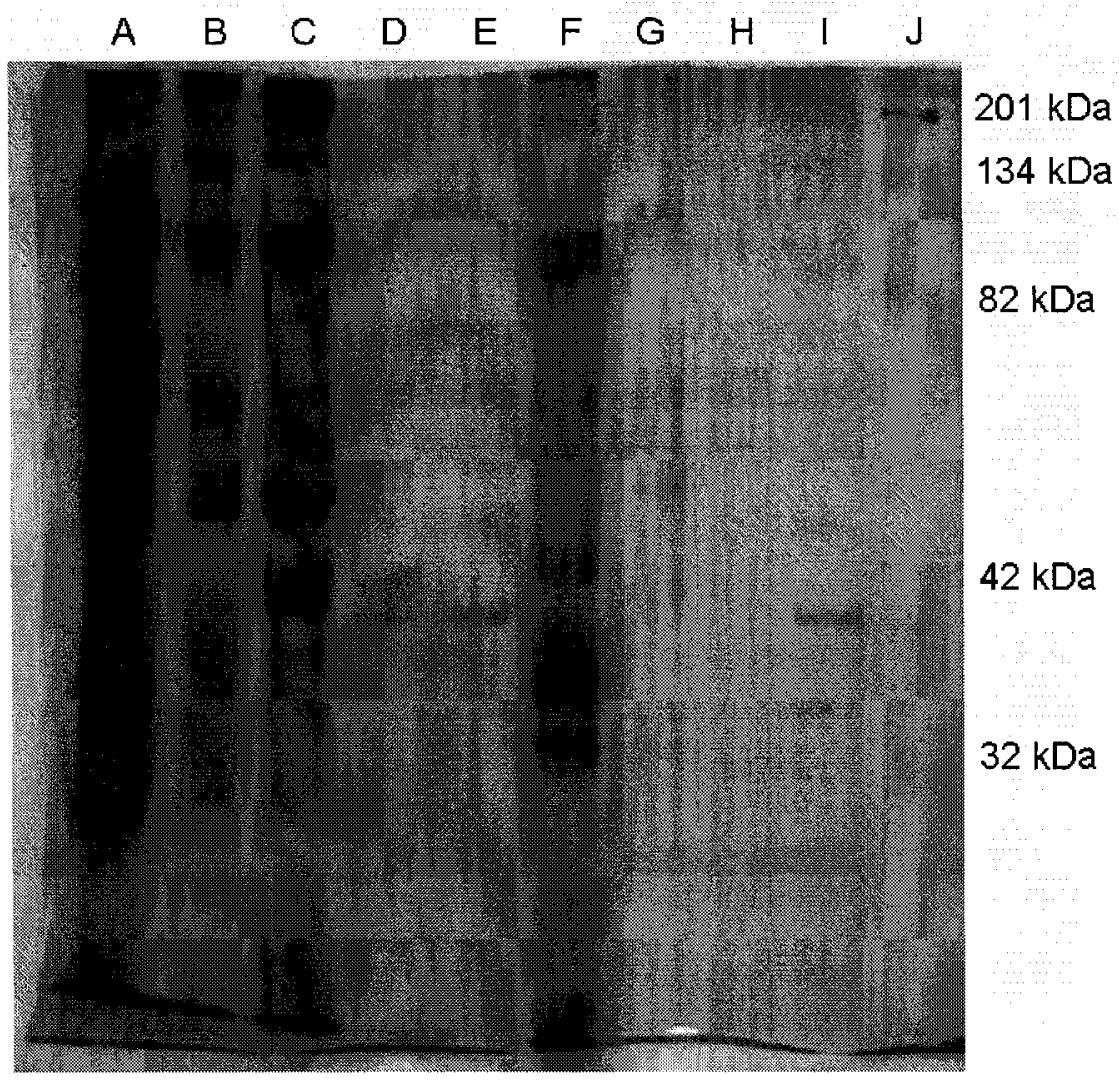


Figure 4.5. Elution profiles of $O$. lactea type-1 phosphatase activity from a SephacrylS400 gel filtration column for foot muscle extracts from (A) active snails and (B) estivating snails. Phosphatase activity was recovered from crude extracts without any prior treatments to remove regulatory subunits. Activity was measured under optimal $\mathrm{V}_{\max }$ conditions at $22^{\circ} \mathrm{C}$ using phosphorylase a as the substrate. Elution profiles are representative of $\mathbf{n}=3$ independent trials. Molecular weight standards are shown as open triangles and are as follows: (1) thyroglobulin, $670 \mathrm{kDa}$; (2) Jack Bean urease, $545 \mathrm{kDa}$; (3) Bacillus pasteurii urease, $272 \mathrm{kDa}$; (4) hemoglobin, $64.5 \mathrm{kDa}$; and (5) cytochrome C, $12.5 \mathrm{kDa}$. 

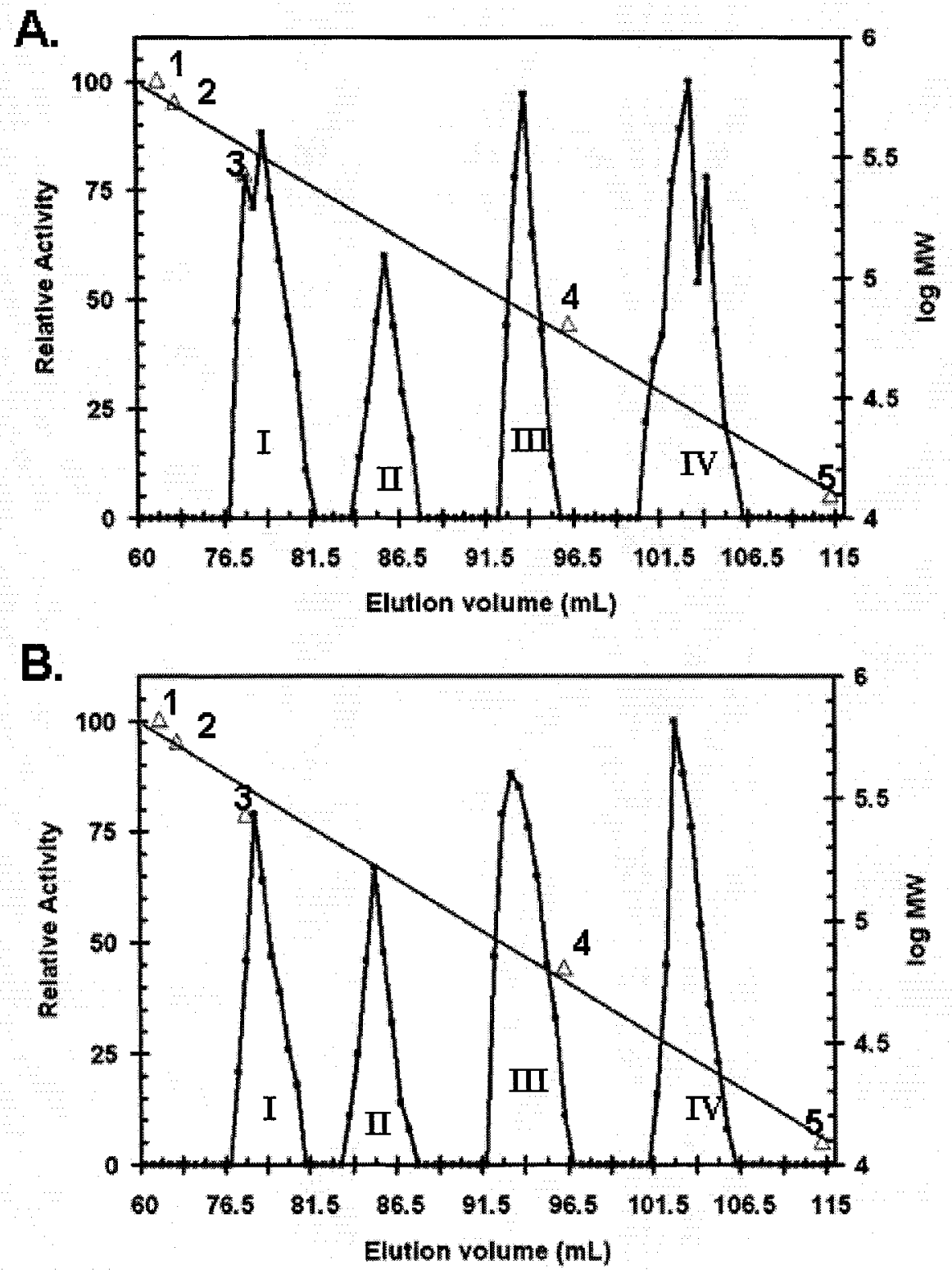


\section{Discussion}

The $O$. lactea phosphatase activity detailed in this study was attributed to PP1, due to its similarities to classically defined type- 1 protein phosphatase. Thus, activity was insensitive to sodium orthovanadate, a specific inhibitor of tyrosine-specific phosphatases (Brautigan et al., 1981), ion-independent (a characteristic of type-1 and type-2A Ser/Thr phosphatase) and sensitive to okadaic acid within the range of that is typical of other PP1 enzymes ( $I_{50}$ values were 55-99 nM) (Cohen, 1989; Cohen et al., 1989; Shenolikar, 1994). The $O$. lactea type-1 enzyme also showed strong activity towards phosphorylase a, the best-known PP1 substrate in both vertebrates (Cohen, 1989; Cohen et al., 1989; Neumann et al., 1999) and invertebrates (Dombradi et al., 1987; Pondovan and Cohen, 1987; Pfister and Storey, 2002; 2006a, 2006b). The enzyme also showed strong activity towards Kemptide (the peptide sequence containing the phosphoserine site in pyruvate kinase) (McNall and Fischer, 1988; Pinna and Donella-Deana, 1994; Zhang and Lee, 1997) and P-NPP which is a substrate for type-1 phosphatases in certain animal systems (Li et al., 1979; Silberman et al., 1984). Type-1 and type-2A phosphatases can also be distinguished by their actions towards phosphorylated casein which is a suitable substrate only for PP-2A, since PP1 activity towards casein is very low (Cohen, 1989). We found negligible activity towards casein in preliminary studies of the $O$. lactea enzyme, further indicating that the phosphatase under study was PP1.

The marine toxin okadaic acid, a known inhibitor of type-1 and type-2A activity, can also be used to distinguish between PP1 and PP2A, since the former is typically inhibited only by high concentrations and the latter is inhibited at 100 -fold lower concentrations (Cohen, 1989; Cohen et al., 1989; Shenolikar, 1994, Neumann et al., 
1999; Lietdke et al., 2005). In O. lactea, type-2A activity towards casein was completely abolished with $5 \mathrm{nM}$ okadaic acid in tissues from both active and estivating snails and featured $\mathrm{I}_{50}$ values in the range of $1.0 \mathrm{nM}$ (see Chapter 4). Far higher concentrations of okadaic acid were required to inhibit type- 1 activity in active snail extracts ( $I_{50}$ values were $99 \mathrm{nM}$ for foot muscle and $85 \mathrm{nM}$ for hepatopancreas). Even in estivation, where type-1 activity was significantly more sensitive to okadaic acid inhibition, $\mathrm{I}_{50}$ values were 54-73 nM, comparable to the okadaic inhibition profile of type-1 phosphatase activity towards phosphorylase a from other sources such as liver from the turtle Trachemys scripta elegans (Mehrani and Storey, 1995a) and mature larvae from the insect species Epiblema scudderiana and Eurosta solidaginis (Pfister and Storey, 2002). Thus, $O$. lactea type-2A and type-1 phosphatase activities displayed typical differential sensitivity to okadaic acid.

Type-1 phosphatase activity from $O$. lactea also displayed typical PP1 properties during purification. Treatment with ethanol or trypsin increased recoverable type-1 phosphatase activity in crude extracts of both snail tissues. In addition, untreated foot muscle extracts subjected to gel filtration typically featured four peaks of type-1 phosphatase activity in foot muscle of both active and estivating snails, ranging in size from 257 to $40 \mathrm{kDa}$ (determined from gel filtration calibration). SDS-PAGE of peak III $(76 \mathrm{kDa})$ and IV $(40 \mathrm{kDa})$ showed one band each that confirmed the size calculated from gel filtration, whereas peak I ( $257 \mathrm{kDa}$ ) featured several faint bands after electrophoresis, including two large bands $>200 \mathrm{kDa}$, one of which could correspond to a large PP1 complex. After treatment with ethanol or trypsin, only one peak of activity eluted from gel filtration, corresponding to the lowest molecular weight (peak IV; $40 \mathrm{kDa}$ ). Taken 
together, these results indicate that trypsin and ethanol incubations liberated the snail catalytic subunit (PP1c) from inhibitory complexes of higher molecular masses. This agrees with studies of PP1 from rabbit liver, where it was first established that PP1c could be liberated from regulatory subunits; in those studies, PP1 activity in protein complexes of $150-180 \mathrm{kDa}$ were abolished after trypsin or ethanol treatment and activity appeared instead in fractions corresponding to 33-38 kDa (Brandt et al., 1974; 1976; Erdodi et al., 1985). Similar studies in bovine heart (Dickey-Dunkirk et al., 1985), rabbit skeletal muscle (McNall and Fischer, 1988; McNall et al., 1988), and rat liver (Bollen and Stalmans, 1988; Stephenson, 1991), generally determined that trypsin or ethanol treatment could dissociate and activate $35-38 \mathrm{kDa}$ PP1c bound to larger regulatory complexes. Studies with invertebrate species have shown similar ethanol/trypsin effects on PP1 activity in Drosophila melanogaster, with a PP1c of comparable size (33 kDa) and amino acid sequence ( $92 \%$ identity) to the vertebrate enzyme (Dombradi et al., 1987; Cohen, 1989). SDS-PAGE of $O$. lactea PP1 peaks from gel filtration suggested that peak III (75 kDa) was relatively stable, as this peak could not be denatured into the $40 \mathrm{kDa}$ catalytic subunit, whereas peak I (257 kDa) appeared to have been partially denatured into component parts (bands at $60 \mathrm{kDa}$ and $100 \mathrm{kDa}$ ), although no $40 \mathrm{kDa}$ subunit was detected.

Type-1 phosphatase activity in $O$. lactea foot muscle also showed typical PP1 properties during purification in several other regards, including the aforementioned molecular weight of the catalytic subunit, and affinity for microcystin (Moorhead et al., 1995; MacDonald and Storey, 2002; Pfister and Storey, 2002) and heparin (Gergely et al., 1984; Erdodi et al., 1985) columns. However, during initial heparin chromatography 
experiments, a phosphatase of type-2A activity also bound to the column after washing with the column with buffer A; type-2A and type-1 activities eluted at $\sim 0.07$ and $\sim 0.4 \mathrm{M}$ $\mathrm{NaCl}$, respectively. In previous studies, PP2A from rabbit muscle (Gergely et al., 1984), rabbit liver (Erdodi et al., 1985), bovine platelets (Erdodi et al., 1992) and failing human hearts (Neumann et al., 1999) were excluded from heparin columns and recovered entirely in the flow-through. Hence, it was suggested that heparin chromatography could effectively separate type- 1 and type-2A phosphatases but clearly this is not the case for O. lactea phosphatases. O. lactea type-2A activity was recovered in both the heparin flow-through and with a $0.1 \mathrm{M} \mathrm{NaCl}$ bump off the heparin column, similar to reports for solubilized-membrane phosphatases of Paramecium tetraurelia (Klumpp et al., 1990). Thus, the inclusion of $0.1 \mathrm{M} \mathrm{NaCl}$ in buffer $\mathrm{A}$ was necessary for washing the heparin column (to elute type-2A) prior to the $0.5 \mathrm{M} \mathrm{NaCl}$ bump that eluted PP1. This was an important purification step in this system since 0 . lactea type-2A and type-1 phosphatases eluted similarly from both the Sepharose gel filtration and microcystin affinity steps (data not shown).

Another purification property of $O$. lactea type-1 phosphatase that is typical of PP1 enzymes is the affinity for microcystin, which has been utilized in the purification of PP1 from several vertebrate (Moorhead et al., 1995; MacDonald and Storey, 2002) and invertebrate (Pfister and Storey, 2002) sources. Hence, in terms of the biochemical characterization of $O$. lactea phosphatase activity, the pharmacological responses to okadaic acid, and behaviour of the enzyme in different purification steps, the $O$. lactea phosphatase characterized in this study was classified as a type- 1 phosphatase enzyme. The next goal was to determine if PP1 activity was differentially regulated during 
estivation in $O$. lactea. Estivation had little effect on PP1 in the spadefoot toads Scaphiopus couchii (Cowan et al., 2000). The role of PP1 also varied in other animal systems known to depress metabolic rate under conditions analogous to estivation. PP1 activity was reduced in response to anoxia in the turtle T. s. elegans (Mehrani and Storey, 1995a) and the crayfish Orconectes virilis (Cowan and Storey, 2001b). In both turtles and crayfish, PP1 suppression was generally accompanied by an increase in protein kinase A (PKA) activity at the onset of anoxia exposure (during the hypoxia transition period) but both PKA and PP1 activities were suppressed when full anoxia was established and metabolic rate was reduced to low levels (Mehrani and Storey, 1995a,b; Cowan and Storey, 2001b). A decrease in PP1 was also associated with anoxia exposure in skeletal muscle of the wood frog Rana sylvatica (MacDonald and Storey, 2002). Conversely, PP1 activity increased during freezing in this vertebrate model.

In the present study, PP1 was suppressed during estivation in $O$. lactea when measured in crude extracts of foot muscle and hepatopancreas. Parameters indicative of this included reduced maximal velocities, reduced substrate affinities for phosphorylase a and Kemptide, and increased sensitivity to the pharmacological PP1 inhibitor, okadaic acid (Table 4.1). However, PP1 activity in estivating snails generally displayed increased resistance to physiological inhibitors such as $\mathrm{AMP}, \mathrm{ADP}$, and $\mathrm{NaCl}$. This may reflect an adaptation in PP1 functional stability specific to the estivated condition, as adenylate energy charge is maintained at a high level in this animal during estivation (Churchill and Storey, 1989c) and salt concentrations increase in estivators as a consequence of dehydration. The decreased type- 1 phosphatase activity in estivating $O$. lactea tissues may be analogous to similar PP1 suppression noted above in other systems, and along 
with the decrease seen in PKA activity during snail estivation (Brooks and Storey, 1996), could be evidence of a coordinated regulation of kinases and phosphatases to facilitate the overall suppression of metabolism in this model. Decreased PP1 activity in estivation is also consistent with established studies that show that proteins that are PP1 substrates are maintained in a phosphorylated state in dormant snails (Brooks and Storey, 1997; Storey, 2002; see also Chapters 2 and 3).

The microcystin-purified catalytic subunits of PP1 from active and estivated snail foot muscle were indistinguishable in all parameters tested (Table 4.3), evidence that the estivation-associated decrease in PP1activity identified in crude extracts is not due to modification of the isolated catalytic subunit. Instead, gel filtration profiles of extracts from active and estivated snails that were untreated by trypsin or ethanol showed that the decrease in PP1activity during estivation could be attributed to a change in the population of functional PP1 holoenzyme complexes. In estivation, there was a significant increase in the relative population of PP1 activity associated with a protein size of $76 \mathrm{kDa}$, and a significant decrease in the amount of PP1 activity associated with the $257 \mathrm{kDa}$ protein size. Kinetic studies of these isolated peaks revealed that the $76 \mathrm{kDa}$ PP1 structure had characteristics of a less active enzyme (low affinity for substrate and high sensitivity to okadaic acid inhibition), whereas the $257 \mathrm{kDa}$ holoenzyme had the highest substrate affinity and lowest okadaic acid sensitivity of the four peaks characterized (Table 4.4). This indicates that a change in the relative proportions of the different holoenzymes is likely the basis for the decrease in overall PP1activity that was measured in crude tissue extracts from estivating snails. 
Thus, it appears that $O$. lactea $\mathrm{PP} 1$ activity in the estivating condition is regulated by differential association of PP1c into functional holoenzyme complexes. This could have been predicted, as the physiological roles of PP1 in many animal systems are determined by well-defined proteins that bind the catalytic subunit and regulate its activity (MacDonald, 2004). These proteins typically bind PP1c in a 1:1 ratio and are classified as either inhibitory or targeting subunits based on how they influence phosphatase activity. While PP1 can show nonspecific phosphatase activity in vitro with many phosphorylated substrates, functionally relevant PP1 activity is thought to be determined by these subunits that localize PP1c to particular cellular regions with specific substrates (MacDonald, 2004). Mammalian PP1 regulatory proteins that have been characterized include glycogen binding subunits in muscle and liver $\left(G_{M}\right.$ and $\left.G_{L}\right)$, myosin targeting subunits in smooth and skeletal muscle (MYPT1 and MYPT2), nuclear inhibitor of PP1 (NIPP1), heat shock protein HSP78, the growth arrest and DNA damage protein GADD-34, and inhibitor-1 and inhibitor-2 (MacDonald, 2004).

Whereas PP1 binding proteins have been thoroughly characterized in many vertebrate models (Cohen, 1989), PP1 regulatory subunits have not been studied to any significant extent in invertebrate species. A $31 \mathrm{kDa}$ protein was isolated in oocytes of the starfish species Asterias rubens and Marthasterias glacialis and characterized as being similar in function and in size to the vertebrate inhibitor-2 protein (Pondovan and Cohen, 1987). The present study did not isolate any of the regulatory elements that bound PP1c in $O$. lactea, although it is apparent that, assuming the 1:1 binding ratio seen in other animals, that the PP1 regulatory subunits would be of approximate sizes $217 \mathrm{kDa}, 95$ $\mathrm{kDa}$, and $36 \mathrm{kDa}$ for peaks I, II, and III from gel filtration chromatography. Furthermore, 
since the $217 \mathrm{kDa}$ subunit facilitated a more active PP1 enzyme, and the $36 \mathrm{kDa}$ subunit was associated with a lower activity type-1 phosphatase, these subunits might be classified as targeting versus inhibitory subunits, respectively. However, SDS-PAGE analysis failed to resolve proteins at these particular molecular weights.

In summary, the phosphatase activity characterized in $O$. lactea foot muscle and hepatopancreas in the present study displayed typical characteristics of, and was classified as, type-1 phosphatase activity. PP1 activity was reduced during estivation in crude extracts of both tissues, whereas analysis of the purified $40 \mathrm{kDa}$ catalytic subunit from active and dormant snails showed similar kinetics. Gel filtration purification of nontrypsin treated foot muscle extracts showed that snail PP1 associated with four distinct protein sizes, and that the relative population of these different proteins changed in estivation. The decrease in total PP1 activity in estivation could be attributed to an increase in the population of the $76 \mathrm{kDa}$, low activity PP1 complex and a decrease in the population of the $257 \mathrm{kDa}$, high activity phosphatase holoenzyme. 


\section{CHAPTER 5 \\ Type-2 serine/threonine phosphatases and tyrosine protein phosphatase profiles in the estivating snail, Otala lactea}




\section{Introduction}

The established importance of reversible protein phosphorylation in controlling key enzymes and metabolic functions in estivating snails implies a major regulatory role for the enzymes that catalyze phosphorylation (protein kinases) and dephosphorylation (protein phosphatases) events. The previous chapter examined the level of protein phosphatase type-1 activity in $O$. lactea. However, other protein phosphatases may also be key players in metabolic control when the animals enter/exit from dormancy. These phosphatases include the type-2 phosphatases (PP2 family of enzymes) and the protein tyrosine phosphatases (PTP enzymes).

PTPs are either membrane bound or free in the cytosol (Fischer et al., 1991; Alonso et al., 2004) and both forms have been described in invertebrates (Zinn, 1993). Membrane-associated PTPs are activated by binding of effector molecules to membrane receptors and serve to dephosphorylate different proteins such as nonreceptor tyrosinespecific kinases and phosphatases, which then dephosphorylate downstream substrates that include serine/threonine specific kinases and phosphatases (Cohen, 1989; Cobb and Goldsmith, 1995). PTPs typically consist of a catalytic domain and at least one major structural domain that can either function to regulate phosphatase activity or target/localize PTP activity to other proteins or phospholipids (Alonso et al., 2004).

In contrast to the multidomain PTPs, serine/threonine phosphatases typically consist of small catalytic subunits that are complexed with one or more regulatory or targeting subunits (Cohen, 1989; Alonso et al., 2004). This results in a large number of distinct holoenzyme structures that can be distinguished into type-1 and type- 2 phosphatases based on biochemical properties. Type-2 phosphatases can be distinguished 
from type-1 phosphatases by various biochemical properties, including the preferred dephosphorylation by PP2 of the alpha-subunit of phosphorylase kinase and insensitivity to I-1 and I-2 (Cohen, 1989). Type-2 phosphatases can be further subdivided as type-2, type-2B, and type-2C phosphatases based on purification properties, ion requirements, substrate affinities, and inhibitor sensitivities. This classification system was developed for mammalian phosphatases but has been shown to extend to many invertebrate species (Cohen, 1989).

Protein phosphatase type-2A (PP2A) is ion independent, can be purified using microcystin chromatography, is sensitive to nanomolar concentrations of okadaic acid, and typically consists of a heterotrimeric complex with a $38 \mathrm{kDa}$ catalytic subunit complexed to a regulatory $60 \mathrm{kDa}$ subunit and another regulatory subunit of variable size (Kamibayashi et al., 1991). Protein phosphatase type-2B (PP2B) is calcium and calmodulin dependent, inhibited by synthetic chemicals such as cypermethrin (Alexanian and Bamburg, 1999), can be purified using calmodulin affinity chromatography, and typically consists of a regulatory $60 \mathrm{kDa}$ catalytic subunit and a $20 \mathrm{kDa}$ calcium binding subunit (Hellstern et al., 1997). Protein phosphatase type-2C is a magnesium dependent, $45 \mathrm{kDa}$ monomer that can be purified using Cibacron Blue affinity chromatography (Klumpp and Selke, 1998). PP2C is distinct from the other phosphatases in that no regulatory subunits or specific inhibitors are known (Rogers et al., 2006).

Estivation-associated modifications of these phosphatases were evident in organs of the desert toad Scaphiopus couchii (Cowan et al., 2000; Cowan and Storey, 2001a) but PP2 and PTP activities have yet to be examined in an invertebrate model of estivation. The present chapter characterizes these phosphatases in active and estivating $O$. lactea. 


\section{Methods and Materials}

\section{Animals and Chemicals}

Details of animal holding, experimentation and sampling are as in Chapter 2. Phosphatase inhibitors and RII peptide were purchased from Calbiochem (San Diego, CA, USA), all other peptide substrates were synthesized at Queen's University (Kingston, Ontario, Canada), and centrifugal concentrating devices were purchased from Pall Life Sciences (Ann Arbor, MI, USA). All other chemicals were obtained from Sigma (St. Louis, MO, USA).

\section{Sample preparation}

Frozen tissue samples were generally homogenized 1:5 w:v for PP2B or 1:3 w:v for PTP assays in cold $\left(4^{\circ} \mathrm{C}\right)$ buffer A containing $50 \mathrm{mM}$ imidazole, $\mathrm{pH} 7.0,10 \% \mathrm{v}: \mathrm{v}$ glycerol, 2 mM EDTA, 2 mM EGTA, and 10 mM 2-mercaptoethanol, using a Polytron PT1000 homogenizer (Brinkmann Instruments, Rexdale, ON). A few crystals of phenylmethylsulfonyl fluoride (PMSF) and 1:1000 (v:v) Sigma Protease Inhibitor Cocktail were added at the time of homogenization. Homogenates were centrifuged at $10,000 \mathrm{x}$ g for 20 minutes at $4^{\circ} \mathrm{C}$ and the supernatant was removed and kept on ice until assay (when determining phosphatase activities in crude extracts).

\section{Subcellular distribution of phosphatase activities}

To determine the subcellular localization of phosphatase activities in active and estivating snails, tissue extracts were fractionated into nuclear (NUC), mitochondrial 
(MIT), plasma membrane (PM) and cytoplasmic (CYT) fractions. Nuclei were first separated by modifying the protocols of Bruhat et al. (2000) and Guseva et al. (2004). Frozen tissue samples were homogenized 1:2 w:v in buffer B (20 mM HEPES, pH 7.9, $10 \mathrm{mM} \mathrm{KCl}, 2 \mathrm{mM} \mathrm{MgCl}$, $1 \mathrm{mM}$ EDTA, $1 \mathrm{mM}$ dithiothreitol, $10 \%$ v:v glycerol) using 20 pestle strokes of a Dounce homogenizer (Kontes Glass Company, Vineland, NJ); as above, PMSF and Sigma Protease Cocktail were added at the time of homogenization. Homogenates were centrifuged at 2,000 $\mathrm{x}$ g to pellet nuclei. The postnuclear supernatant was removed and subjected to further fractionation (detailed below), and the pellet was resuspended in extraction buffer (buffer $\mathrm{B}$ with $\mathrm{KCl}$ increased to $500 \mathrm{mM}$ ), gently mixed for $1 \mathrm{~h}$ at $4^{\circ} \mathrm{C}$, and centrifuged at $10000 \mathrm{x}$; the supernatant from this spin was saved as the NUC fraction.

Further fractionation of the postnuclear supernatant was performed by modifying the protocol from Cowan and Storey (2001b). Supernatant was layered over an equal volume of buffer B containing $500 \mathrm{mM}$ sucrose and centrifuged at $1000 \mathrm{x} \mathrm{g}$ for $10 \mathrm{~min}$. The pellet from this spin was resuspended in buffer C (buffer B containing $500 \mathrm{mM}$ sucrose and $0.5 \% \mathrm{v} / \mathrm{v}$ sodium deoxycholate), and centrifuged again (1000 x g for 10 min). The pellet was resuspended in buffer $\mathrm{C}$ as the PM fraction. The supernatant from the first $1000 \mathrm{x} \mathrm{g}$ spin was centrifuged at $13,000 \mathrm{x} \mathrm{g}$ for $30 \mathrm{~min}$. The supernatant was removed and saved as the CYT fraction whereas the pellet was resuspended in buffer C and represented the MIT fractions. Subcellular fractions were kept on ice and assayed immediately for phosphatase activity.

The quality of subcellular fractionation was assessed using the enzymes $\mathrm{Na}^{+} \mathrm{K}^{+}$ATPase, citrate synthase (CS), and glucose-6-phosphate dehydrogenase (G6PDH) as 
markers for PM, MIT, and CYT fractions, respectively. Assay conditions were as described in Chapters 2 and 3 or by Hermes-Lima and Storey (1995) for CS.

\section{Removal of regulatory subunits.}

Crude soluble extracts were subjected to treatments at $22^{\circ} \mathrm{C}$ that have been established as methods that could remove potential inhibitory regulatory subunits (detailed in Chapter 4). Untreated, ethanol-treated, $\left(\mathrm{NH}_{4}\right)_{2} \mathrm{SO}_{4}$-treated, and trypsin-treated extracts were desalted by passage through Sephadex G-25 columns (100 $\mu \mathrm{L}$ of extract on $1 \mathrm{~mL}$ columns) equilibrated in buffer $\mathrm{A}$; treatments that increased recoverable phosphatase activities were then included in subsequent purification trials.

\section{Purification scheme to isolate and identify serine/threonine phosphatase activities.}

An effort was made to isolate foot muscle phosphatases from each another, and from PP1, which has high activity towards several substrates used in this study, using modifications of established ion exchange, gel filtration, and affinity chromatography methods for serine/threonine phosphatases (Moorhead et al., 1995; Mehrani and Storey, 1995; Selke et al, 1998; Klumpp and Selke, 1998; Feng and Stemmer, 2001; Pfister and Storey, 2002). Methodology was basically the same for foot muscle extracts from both active and estivating snails, and the general scheme is shown in Figure 5.1. Trypsin or ethanol-treated crude extract was added to a $10 \mathrm{~cm} \mathrm{x} 1.8 \mathrm{~cm}(\mathrm{~h} \times \mathrm{d})$ column of DEAEG25 Sephadex (equilibrated in buffer A) and washed with $20 \mathrm{~mL}$ of buffer A to remove unbound protein. This column retained $100 \%$ of type-1, $-2 \mathrm{~A},-2 \mathrm{~B}$, and $-2 \mathrm{C}$ phosphatase activities. The column was then developed with a $0-1 \mathrm{M} \mathrm{NaCl}$ gradient (in buffer $\mathrm{A}$ ) and 
fractions were collected $(\sim 200 \mu \mathrm{L}, 12$ drops $)$ in glass test tubes using a Gilson MicroFractionator. Fractions that tested positive for desired phosphatase activities were pooled and subjected to further purification steps to separate the four phosphatases-types.

Purification of type-2A phosphatase activity. The pooled sample from DEAE chromatography was applied to a column of heparin-agarose $(9.0 \times 1.0 \mathrm{~cm}$, equilibrated in buffer A). After washing with $\sim 20 \mathrm{~mL}$ of buffer $\mathrm{A}$ to remove unbound proteins, the heparin-agarose column retained $100 \%$ of PP1-type activity and partially retained PP2A activity; remaining PP2A and all type-2B and type-2C activities were recovered in the flow-through. PP2A and PP1 activity bound to heparin-agarose were eluted with $0.1 \mathrm{M}$ $\mathrm{NaCl}$ and $0.5 \mathrm{M} \mathrm{NaCl}$ (in buffer A) bumps, respectively, thereby separating PP1 from PP2. Fractions $(0.2 \mathrm{~mL})$ containing PP2A activities from heparin-flow through and from the $0.1 \mathrm{M} \mathrm{NaCl}$ bump were independently subjected to the following purification steps. PP2A activity was loaded onto a $90 \times 2.5 \mathrm{~cm}$ Sephacryl S-400 column that was previously equilibrated overnight with buffer D (buffer A plus $150 \mathrm{mM} \mathrm{NaCl}, 0.04 \% \mathrm{w}: \mathrm{v}$ sodium azide, and $20 \%$ v:v glycerol). The column was developed with buffer D and 0.5 $\mathrm{mL}$ fractions that tested positive for PP2A activity were pooled and concentrated using Pall NanoSep centrifugal devices (MW cutoff $10 \mathrm{kDa})$. Aliquots $(500 \mu \mathrm{L})$ of pooled sample were added to NanoSep reservoirs and centrifuged at 14,000 x g for 6 minutes (per manufacturer's directions) to concentrate the sample down to $\sim 50 \mathrm{uL}$ (10-fold). Concentrated PP2A activity from multiple NanoSep reservoirs was pooled and subjected to affinity chromatography on microcystin-Sepharose, adapting previously described protocols (Moorhead et al., 1995; Kloeker et al., 2003). Approximately $0.5 \mathrm{~mL}$ of concentrated PP2A activity was gently mixed in a small, capped column tube with $\sim 3$ 
$\mathrm{mL}$ of microcystin-Sepharose ( $50 \%$ slurry suspended in buffer $\mathrm{A}+0.5 \mathrm{M} \mathrm{NaCl}$ ) for 30 minutes at $4^{\circ} \mathrm{C}$. The column was then allowed to drain, and the suspension settled into a column matrix $(2.0 \times 1.0 \mathrm{~cm})$ that was washed with five volumes of buffer A containing $0.5 \mathrm{M} \mathrm{NaCl}$ to remove unbound protein. PP2A activity was eluted from microcystinSepharose with buffer A containing $3 \mathrm{M} \mathrm{NaSCN}$ and $2 \mathrm{M} \mathrm{NaCl}$, pooled, and used for kinetic studies.

Purification of Type-2B phosphatase activity. As described above, PP2B activity was recovered in the wash from the heparin-agarose column. These fractions were pooled and subjected to Sephacryl S-400 chromatography on a column equilibrated and thoroughly washed in buffer E (buffer D without EDTA or EGTA). The S-400 column was washed with buffer $\mathrm{E}$ and $0.5 \mathrm{~mL}$ fractions testing positive for PP2B-type activity were pooled and concentrated with NanoSep devices (as above) and then purified further using CaM-Sepharose and the protocols described by Hellstern et al. (1997) and Feng and Stemmer (2001). Concentrated PP2B activity (400 uL) was loaded onto a $3.0 \times 1.0 \mathrm{~cm}$ column of CaM-Sepharose equilibrated in buffer E containing $5 \mathrm{mM} \mathrm{CaCl}_{2}$ and $0.15 \mathrm{M}$ $\mathrm{NaCl}$. All PP2B-type activity was retained by this column after thorough washing with buffer E containing $5 \mathrm{mM} \mathrm{CaCl}_{2}$ and0.15 $\mathrm{M} \mathrm{NaCl}$. Activity was then eluted in buffer $\mathrm{E}$ containing $5 \mathrm{mM}$ EGTA and $0.5 \mathrm{M} \mathrm{NaCl}$; recovered PP2B was pooled and assayed.

Purification of Type-2C phosphatase activity. As for PP2B, all PP2C activity was recovered in the heparin-agarose flow-through. This was pooled and loaded onto a Sephacryl S-400 column equilibrated in buffer E. Fractions containing PP2C activity were pooled, concentrated with a NanoSep device, and added to a $\sim 5.0 \times 1.8 \mathrm{~cm}$ column of Cibacron Blue-Sepharose (equilibrated and washed with buffer E containing $5 \mathrm{mM}$ 
$\mathrm{MgCl}_{2}$ ). All PP2C-type activity was retained by this column. PP2C was then eluted in buffer E containing $100 \mathrm{mM} \mathrm{NaCl}$ and $10 \mathrm{mM}$ EDTA. Fractions containing activity were pooled and assayed.

In addition to gel filtration S-400 chromatography employed in the purification of the individual enzyme types, gel filtration was also used to determine what protein sizes were correlated with phosphatases from crude extracts that had not been treated with trypsin or ethanol, using the same column equilibration conditions as describe above for ethanol or trypsin treated extracts.

\section{SDS PAGE to assess purification and molecular weight}

Samples from various purification steps for PP2A, PP2B, and PP2C were subjected to SDS-PAGE as described in Chapter 2. After electrophoresis, gels were fixed, stained, and destained as described in Chapter 4 for PP1. Gels were then rinsed and stored in water before an image was captured with the ChemiGenius bio-imaging system (Syngene, Frederick, MD).

\section{Phosphatase assays.}

Assays were generally initiated by addition of $25 \mu \mathrm{L}$ of enzyme extract to a final assay volume of $250 \mu \mathrm{L}$ in an Eppendorf tube. For some low activity phosphatases or phosphatase activity eluted from columns, assays were initiated by adding 100-200 uL of enzyme sample to $500 \mathrm{uL}$ final volume. Before all assays, enzyme samples (from crude extracts or from column fractions) were desalted by passing through a Sephadex G-25 column ( $100 \mathrm{uL}$ of extract per $1 \mathrm{~mL}$ of column) that was equilibrated in buffer A. Casein 
substrate solution was also desalted in the same manner to remove inorganic phosphate that otherwise would increase background (Fathi et al., 2002). Because the test phosphatases have shown a broad, overlapping range of activities with respect to the substrates tested, pharmacological inhibitors were used whenever possible to select for the desired activity. When necessary (e.g. in assays involving nonspecific substrates like casein) and possible (ie. not in the case of PP2B activity towards casein, because orthovanadate reduced PP2B activity), background was decreased by adding either 30 $\mathrm{mM}$ sodium fluoride $(\mathrm{NaF})$ for assays of tyrosine phosphatases $(\mathrm{NaF}$ inhibits all serine/threonine phosphatases) or $1 \mathrm{mM}$ sodium orthovanadate $\left(\mathrm{Na}_{3} \mathrm{VO}_{4}\right)$ for assays of serine/threonine phosphatases $\left(\mathrm{Na}_{3} \mathrm{VO}_{4}\right.$ inhibits tyrosine phosphatases). All phosphatase assays were corrected for zero substrate blanks.

Type-2A phosphatase activity. PP2A activity was kinetically characterized using four substrates: kemptide [LRRApSLG], the peptide RRApTVA, casein, and phosphorylase a. Parallel assays were run in the presence versus absence of $5 \mathrm{nM}$ okadaic acid and PP2A activity was defined as activity towards its substrates that was abolished by $5 \mathrm{nM}$ okadaic acid. Activity was measured using $100 \mu \mathrm{M}$ substrate, $25 \mathrm{mM}$ imidazole, pH 7.4, 0.1\% v:v B-mercaptoethanol, 2 mM EDTA, 2 mM EGTA, and $1 \mathrm{mM} \mathrm{Na}_{3} \mathrm{VO}_{4}$. Reaction time was 15 minutes.

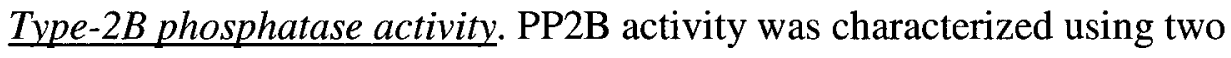
substrates: casein and the RII peptide substrate [DLDVPIPGRFDRRVpSVAAE] that is derived from the protein kinase A (PKA) regulatory subunit type II. Negligible activity was seen towards kemptide and RRApTVA in preliminary studies. PP2B activity was defined as calcium and calmodulin dependent phosphatase activity that was sensitive to 5 
nM cypermethrin, a specific inhibitor of type-2B phosphatase activity. Parallel reactions were run with $5 \mathrm{U}$ calmodulin/assay $+5 \mathrm{mM} \mathrm{CaCl}_{2}$ (experimental) versus $2 \mathrm{mM}$ EGTA + $5 \mathrm{nM}$ cypermethrin (blank). Other assay conditions included $25 \mathrm{mM}$ imidazole, $\mathrm{pH} 7.4$, $0.1 \% \mathrm{v}: \mathrm{v}$ B-mercaptoethanol, $5 \mathrm{mM}$ ascorbic acid, $1 \mu \mathrm{M}$ okadaic acid, $2 \mathrm{mM}$ EDTA, and either $150 \mu \mathrm{uM}$ peptide or $400 \mu \mathrm{M}$ casein. Reaction time was 30 minutes.

Type-2C phosphatase activity. PP2C activity was characterized using phosphorylated casein and the peptide RRApTVA. Negligible activity was seen towards kemptide in preliminary studies. Type-2C activity was defined as the difference in activity towards its substrates between parallel reactions containing $5 \mathrm{mM} \mathrm{MgCl}$ (experimental) versus $2 \mathrm{mM}$ EDTA (blank). Other reaction components were $100 \mu \mathrm{M}$ substrate, $25 \mathrm{mM}$ imidazole, $\mathrm{pH} 7.0,0.1 \%$ v:v $ß$-mercaptoethanol, $1 \mathrm{mM} \mathrm{MnCl} 2,1 \mu \mathrm{M}$ okadaic acid, $2 \mathrm{mM}$ EGTA and $1 \mathrm{mM} \mathrm{Na}_{3} \mathrm{VO}_{4}$. Reaction time was 20 minutes.

Protein tyrosine phosphatase (PTP) assays. PTP activity was assayed with casein and two specific PTP substrates, TYR1 and TYR2, with sequences END(Yp)INASL and DADE(Yp)LIPQQG, respectively. PTP activity was defined as activity towards its substrates that was sensitive to $1 \mathrm{mM} \mathrm{Na}_{3} \mathrm{VO}_{4}$. PTP was assayed in paired reactions (plus or minus $1 \mathrm{mM} \mathrm{Na}_{3} \mathrm{VO}_{4}$ ) using $250 \mu \mathrm{M}$ substrate in $25 \mathrm{mM}$ imidazole, $\mathrm{pH} 7.5,0.1 \% \mathrm{v}: \mathrm{v}$ ß-mercaptoethanol, and $30 \mathrm{mM} \mathrm{NaF}$. Reaction time was 30 minutes.

\section{The ammonium molybdate/malachite green system of detection.}

Phosphatase activity was determined as the amount of inorganic phosphate produced as detected using the ammonium molybdate/malachite green phosphate complexing dye. Reagent was prepared and detection was performed as detailed in 
Chapter 4 . Reactions were stopped by adding an aliquot of assay mixture $(50 \mu \mathrm{L}$ for PP2A and PP2C, $100 \mu \mathrm{L}$ for PP2B and PTP) to a detection tube containing $200 \mu \mathrm{L}$ of dye reagent and $\mathrm{ddH}_{2} \mathrm{O}$ up to $1 \mathrm{~mL}$. After colour development for $15 \mathrm{~min}, 200 \mu \mathrm{L}$ aliquots were transferred to microplates and absorbance at $595 \mathrm{~nm}$ was measured using a MR5000 microplate reader and Biolinx 2.0 software. Phosphate production was determined by comparison with a $\mathrm{KH}_{2} \mathrm{PO}_{4}$ standard curve. All samples were measured in triplicate and averaged. Activity was generally reported as nmol phosphate released per min per mg soluble protein (mU/mg soluble protein), except for subcellular fractionation studies, where activity is reported as $\mu \mathrm{mol}$ phosphate released/min/gram wet mass (U/gwm). Protein concentration was quantified using the Coomassie Blue dye binding method and the BioRad protein prepared reagent with a standard of bovine serum albumin. Enzyme $\mathrm{K}_{\mathrm{m}}$ values for substrates were calculated using the Kinetics 3.51 computer program.

\section{Results}

\section{Optimization of experimental conditions}

Initial trials optimized assay conditions specific to the various phosphatases, as well as validated that recoverable activity was linear with respect to time and to enzyme extract used, as described in Chapter 2.

\section{Stripping of regulatory subunits improves yield of type-2A phosphatase}

Incubation of crude soluble extracts from active snails with either ethanol, ammonium sulphate, or trypsin increased recoverable type-2A activity for both foot muscle and hepatopancreas, while having no effect on type-2B, type-2C, or PTP 
activities in either tissue (Table 5.1). The treatments increased foot muscle PP2A activity by 2.9-3.2 fold whereas comparable increases for hepatopancreas extracts were 1.9-2.5 fold. The stripping treatment generally had a similar effect on PP2A activity in crude extracts from estivating snails (data not shown), and did not reduce the yield of any other phosphatases. Hence, it was included in the procedure to isolate and purify all serine/threonine phosphatases.

\section{Optimization of chromatography procedure to separate serine/threonine phosphatases}

In initial purification schemes, pooled phosphatase activity from DEAE chromatography was added to small columns of poly-L-lysine Sepharose CL-4B, which retained 100\% of PP1 and PP2A activities, whereas PP2B and PP2C activities were not bound and eluted in the wash. However, initial trials determined that PP1 and PP2A eluted from this column with the same concentration of salt $(\sim 0.2 \mathrm{M} \mathrm{NaCl}$ in buffer). Hence, heparin-Sepharose chromatography was tried as a replacement method. This column also retained $100 \%$ of PP1 activity and retained part of PP2A-type activity. PP2B and PP2C were recovered entirely in the flow-through, along with the remainder of the PP2A activity. Heparin-bound activity of PP1-type and PP2A-type were eluted at different concentrations of salt ( $0.5 \mathrm{M}$ and $0.1 \mathrm{M} \mathrm{NaCl}$, respectively), effectively separating PP1 from PP2A. PP1 and PP2A that bound heparin-agarose, as well as PP2A, PP2B, and PP2C that were recovered in the flow-through of the column, were then independently pooled and further purified using Sephacryl S-400 gel filtration. Gel filtration resulted in a dilution of the phosphatase activities, necessitating centrifugal concentration prior to subsequent affinity chromatography steps. Initial experiments 
determined that NanoSep concentrators of MW cutoff of $30 \mathrm{kDa}$ failed to retain $100 \%$ activity, and so subsequent experiments used the NanoSep concentrators of $10 \mathrm{kDa} M W$ cutoff. The final purification steps used microcystin-Sepharose for PP2A, calmodulinSepharose for PP2B, and blue Sepharose for PP2C with elution conditions as shown in Figure 5.1. Of note for PP2A purification was that elution from microcystin-Sepharose required the inclusion of high salt; no activity was recovered from bumps with $3 \mathrm{M}$ $\mathrm{NaSCN}$ alone or $3 \mathrm{M} \mathrm{NaSCN}+0.5 \mathrm{M} \mathrm{NaCl}$ whereas $3 \mathrm{M} \mathrm{NaSCN}+1 \mathrm{M} \mathrm{NaCl}$ eluted some PP2A activity in a broad peak, and only $3 \mathrm{M} \mathrm{NaSCN}+2 \mathrm{M} \mathrm{NaCl}$ resulted in a single sharp peak of activity.

\section{Characterization of PP2A activity in crude extracts and purified preparations}

Maximal PP2A activity in crude extracts from both foot muscle and hepatopancreas was either reduced or unchanged during estivation, as compared with the active state, with all four of the substrates tested (Figure 5.2). In foot muscle extracts from estivated snails, PP2A activity was reduced to $63 \%, 62 \%$, and $60 \%$ of the corresponding value in extracts from active snails when evaluating the substrates casein, RRApTVA, and phosphorylase $\underline{\text { a }}$, respectively. In hepatopancreas extracts, PP2A activity towards casein, kemptide, and RRApTVA was reduced to $74 \%, 63 \%$, and $74 \%$ of the respective values in active extracts. For both tissues, recoverable PP2A activity was highest when using casein or RRApTVA as substrates, and much lower with kemptide or phosphorylase a.

Kinetic parameters for PP2A in crude extracts of foot and hepatopancreas are shown in Table 5.2. Affinities for RRApTVA and casein were significantly reduced $\left(K_{m}\right.$ 
increased) during estivation in extracts from both tissues as compared with active snails; $\mathrm{K}_{\mathrm{m}}$ values increased 1.3- and 1.5-fold in foot muscle and 1.8- and 1.3-fold in hepatopancreas for the casein and RRApTVA, respectively. However, PP2A activity towards kemptide was not affected by estivation. Responses to several potential inhibitors were also characterized for PP2A from estivating versus active snail tissues but no significant differences were found between the two states.

During purification (following the scheme in Figure 5.1), PP2A activity was associated with two groups of protein: enzyme that bound to heparin-Sepharose (eluted with $0.1 \mathrm{M} \mathrm{NaCl}$ ), and enzyme that did not bind to the heparin column and was recovered in the flow-through. Subsequent gel-filtration on Sephacryl-S400 showed that the heparin-binding type-2A activity was associated with a protein size of $35 \pm 3 \mathrm{kDa}(\mathrm{n}=3)$, whereas the type-2A activity in the flow through was associated with a protein size of $200 \pm 7 \mathrm{kDa}(\mathrm{n}=3)$. Representative Sephacryl-S400 gel filtration elution profiles of trypsin-treated crude extracts from foot muscle of active (Figure 5.3A) and estivating (Figure 5.3B) snails PP2A displayed two peaks of activity (I and II), corresponding to the sizes of the $200 \mathrm{kDa}$ heparin-nonbinding and the $35 \mathrm{kDa}$ heparin-binding proteins, respectively. In addition, Sephacryl-S400 runs using extracts that were not given prior stripping treatment featured a third peak of type-2A activity (III) in both active and estivated foot muscle (Figure 5.3C and D) corresponding with a size of $95 \pm 5 \mathrm{kDa}(\mathrm{n}=3)$. This third peak disappeared whenever gel filtration was preceded with ethanol or trypsin treatment.

Estivation altered the distribution of PP2A activity between the two peaks in trypsin-treated extracts (Figure 5.3A and B). Extracts from estivating snails consistently 
featured a higher proportion of the Peak I, $200 \mathrm{kDa}$ heparin-nonbinding enzyme $(52 \pm 4 \%$ of total recovered PP2A activity) compared with $24 \pm 4 \%$ of total activity in this peak in extracts from active snail extracts and vice versa for activity in Peak II (data are means \pm S.E.M for $n=3$ independent trials). The same shift was seen when the three peaks in untreated extracts were analyzed (Figure 5.3 C and D); the distribution in extracts from estivated snails was $62 \pm 3 \%, 17 \pm 3 \%$, and $21 \pm 3 \%$ of total PP2A activity in Peaks I, II, and III, respectively, whereas in extracts from active snails the corresponding values were $32 \pm 5 \%, 44 \pm 5 \%$, and $24 \pm 5 \%$. The proportion of activity in Peak III did not change between active and estivated states.

The purification scheme for the $35 \mathrm{kDa}$ heparin-binding PP2A catalytic subunit is summarized in Table 5.3 for the heparin-binding activity from foot muscle of active snails. PP2A was purified 412-fold to a final specific activity of $148 \mathrm{mU} / \mathrm{mg}$ soluble protein, with a $16 \%$ yield. The same scheme was also applied to the heparin-nonbinding activity, which was purified 293-fold to a final specific activity of $99 \mathrm{mU} / \mathrm{mg}$ soluble protein (data not shown). A representative SDS-PAGE gel from one of the purification trials is shown in Figure 5.4. After both the heparin chromatography and gel filtration steps, heparin-binding PP2A fractions featured two bands, at $75 \mathrm{kDa}$ and $35 \mathrm{kDa}$, but after the final microcystin chromatography the purified enzyme preparation showed only one band at $35 \mathrm{kDa}$. Gel filtration of heparin-nonbinding PP2A activity featured multiple protein bands, but subsequent microcystin chromatography resulted in one band corresponding to the $35 \mathrm{kDa}$ catalytic subunit.

Kinetic properties of the final, purified heparin-binding and nonbinding type-2A phosphatase activities from foot muscle are compared in Table 5.4. $\mathrm{K}_{\mathrm{m}}$ and $\mathrm{I}_{50}$ values for 
heparin-binding PP2A activity did not change between the active and estivating conditions, whereas the properties of the heparin-nonbinding PP2A changed significantly between the two states. The $\mathrm{K}_{\mathrm{m}}$ values for RRApTVA and casein were 1.5- and 1.9-fold higher, respectively, for the enzyme from estivated versus active snails whereas $\mathrm{I}_{50}$ values for okadaic acid and endothall were reduced by $50 \%$ and $28 \%$, respectively.

\section{Characterization of PP2B-type activity in crude extracts}

PP2B-type activity in foot muscle was too low for accurate analysis and so studies of this enzyme were pursued only with hepatopancreas. Maximal activity towards casein or the type-2B specific RII peptide did not differ significantly between active or estivated states when crude extracts were assessed, nor did ethanol or trypsin treatment increase the amount of recoverable activity. However, the kinetic properties of type-2B phosphatase in crude extracts did change significantly during estivation (Table 5.5). The enzyme from estivating snails showed a reduced affinity for substrates (1.3- and 1.5-fold increases in $\mathrm{K}_{\mathrm{m}}$ values for casein and RII, respectively) and decreased responsiveness to activation by calcium (1.4-fold increase in $\mathrm{K}_{\mathrm{a}} \mathrm{Ca}^{2+}$ ). There were no differences between active and estivating states in the response to calmodulin or ascorbic acid activation or cypermethrin inhibition.

PP2B activity was purified from hepatopancreas of active snails as shown in Figure 5.1 and Table 5.6 shows a representative purification run. Type-2B activity was purified 170 -fold to a final activity of $13.3 \mathrm{mU} / \mathrm{mg}$ soluble protein with $7 \%$ yield. Sephacryl-S400 gel filtration determined that type-2B activity was associated with one peak corresponding to a protein size of $54 \pm 4 \mathrm{kDa}(\mathrm{n}=3$ independent trials). A representative SDS-PAGE gel from one of the purification trials featured one band at 50 
$\mathrm{kDa}$ after calmodulin chromatography (Figure 5.5). The purified activity was too low and unstable to pursue kinetic characterization.

\section{Characterization of PP2C-type activity in crude extracts and purified preparations.}

PP2C-type maximal activity was decreased by $33 \%$ in extracts of foot muscle from estivating snails, but increased 1.6-fold in hepatopancreas, relative to the respective activities in active animals (Table 5.7). Estivation also significantly affected substrate affinities of the hepatopancreas type-2C enzyme with $\mathrm{K}_{\mathrm{m}}$ values for RRApTVA and casein falling to 54 and $64 \%$ of the corresponding active values, respectively. Hepatopancreas PP2C from active versus estivated snails also showed a differential response to manganese (Figure 5.6), and the $\mathrm{K}_{\mathrm{a}}$ for $\mathrm{Mn}^{2+}$ in extracts from estivating snails fell to $67 \%$ of the value in active extracts. Kinetic properties of foot muscle PP2C were largely unaffected between the active and estivating states except for a 1.4-fold higher $\mathrm{I}_{50}$ for urea during estivation.

A representative purification trial for type-2C activity from foot muscle is detailed in Table 5.8, and a representative SDS-PAGE gel from PP2C purification is shown in Figure 5.7. PP2C was purified 250 -fold to a final activity of $28.8 \mathrm{mU} / \mathrm{mg}$, recovering $8 \%$ of original activity. The enzyme showed a native molecular weight of $36 \pm 2 \mathrm{kDa}(\mathrm{n}=3)$ on gel filtration; this size was confirmed by the representative SDS-PAGE gel, which illustrated one band at $35 \mathrm{kDa}$ after Cibacron Blue chromatography. Analysis of some kinetic properties of purified PP2C showed very similar results for crude extracts, except that purified PP2C was not appreciably activated by manganese ion (data not shown). 


\section{Characterization of PTP-type activity in crude extracts.}

Total PTP activity was assayed in crude extracts using two different peptides, TYR 1 (ENDYpINASL) and TYR2 (DADEYpLIPQQG), to assess the two general groups of PTPs. Table 5.9 shows that no significant differences in the maximal activities or substrate affinities for TYR1 and TYR2 were found between active and estivated states in either foot muscle or hepatopancreas. PTP activity was also tested using casein as a substrate but yielded only $\sim 10 \%$ of the activity seen towards the tyrosine phosphatase specific peptides.

Estivation-dependent changes in subcellular distribution of foot muscle phosphatases.

Subcellular fractionation separated nuclear, mitochondrial, plasma membrane and cytosolic fractions of foot muscle. No measurable activity of any phosphatase was recovered from the NUC fraction and PP2B activity was negligible foot muscle extracts. The distributions of PP2A, PP2C and PTP activities in CYT, MIT and PM fractions are presented in Figure 5.8. Assays of marker enzymes chosen to represent each of these subcellular fractions (G6PDH, CS, $\mathrm{Na}^{+} \mathrm{K}^{+}$-ATPase) showed appropriate and expected enrichment in CYT, MIT, and PM fractions, respectively, relative to crude soluble extracts (Table 5.10). Hence, successful fractionation of subcellular compartments was confirmed. Each phosphatase showed its own distribution between the three subcellular fractions.

Estivation resulted in significant changes in the subcellular distribution of all three enzyme activities. Figure 5.8A shows that type-2A phosphatase activity was significantly reduced by $24 \%$ in CYT and $37 \%$ in PM fractions from estivating snails, as 
compared with activities in these fractions from active snails. The ratio (x:y:z for CYT, MIT and PM fractions) of PP2A activity changed from 65:8:27 in active foot muscle to 64:13:23 in estivating foot muscle, indicating a greater proportion of overall PP2A activity is located in the MIT fraction in estivation. Type- $2 \mathrm{C}$ phosphatase activity showed enrichment in the MIT fraction (a 1.8-fold increase) during estivation relative to active foot muscle (Figure 5.8B). The ratio of PP2C activity changed from 72:12:16 in active snails to $66: 23: 11$ in estivating snails, which confirms that a greater proportion of overall PP2C activity is associated with the MIT fraction. PTP activity was recovered only in CYT and PM fractions, and showed no changes in subcellular distribution between active and estivating snails when tested with TYR1 (Figure 5.8C). The ratio of activity (x:y for CYT and PM) towards TYR1 did not differ between active $(86: 14)$ and estivated $(83: 17)$ foot muscle. However, PTP activity with TYR2 showed a $27 \%$ decrease in the CYT fraction and a 1.8-fold increase in the PM fraction from foot muscle of estivated snails as compared with active animals; the ratio (67:33 in active snails, 45:55 in estivated snails) of CYT vs. PM activity also reflects the increase in PTP activity towards TYR2 in estivating PM. 
Table 5.1. The effect of stripping treatments on recoverable phosphatase activity from crude soluble extracts of active snail foot muscle and hepatopancreas. Activity is expressed as $\mathrm{mU} / \mathrm{mg}$ soluble protein.

\begin{tabular}{|c|c|c|c|c|}
\hline & Crude Extract & Ethanol & Trypsin & $\begin{array}{l}\text { Ammonium } \\
\text { Sulphate }\end{array}$ \\
\hline \multicolumn{5}{|c|}{ Foot Muscle } \\
\hline PP2A & $0.52 \pm 0.08$ & $1.65 \pm 0.11 *$ & $1.49 \pm 0.11^{*}$ & $1.56 \pm 0.13^{*}$ \\
\hline PP2B & NA & NA & NA & NA \\
\hline PP2C & $0.14 \pm 0.03$ & $0.14 \pm 0.04$ & $0.17 \pm 0.05$ & $0.16 \pm 0.03$ \\
\hline PTP & $0.34 \pm 0.07$ & $0.29 \pm 0.08$ & $0.30 \pm 0.05$ & $0.32 \pm 0.05$ \\
\hline \multicolumn{5}{|c|}{ Hepatopancreas } \\
\hline PP2A & $0.79 \pm 0.06$ & $1.97 \pm 0.14^{*}$ & $1.65 \pm 0.18^{*}$ & $1.53 \pm 0.15^{*}$ \\
\hline PP2B & $0.05 \pm 0.01$ & $0.07 \pm 0.01$ & $0.05 \pm 0.02$ & $0.06 \pm 0.01$ \\
\hline $\mathrm{PP} 2 \mathrm{C}$ & $0.17 \pm 0.02$ & $0.14 \pm 0.03$ & $0.16 \pm 0.03$ & $0.13 \pm 0.01$ \\
\hline PTP & $0.33 \pm 0.04$ & $0.41 \pm 0.07$ & $0.36 \pm 0.04$ & $0.29 \pm 0.02$ \\
\hline
\end{tabular}

Assays were conducted at $22^{\circ} \mathrm{C}$ using optimal assay conditions (detailed in Methods) and data are means \pm S.E.M. ( $n=3-5$ independent trials). PP2A and PP2C were measured using casein as the substrate, $\mathrm{PP} 2 \mathrm{~B}$ was measured using RII peptide as the substrate, and PTP was assayed using TYR1 peptide as the substrate. Stripping conditions had the same effect on crude extracts of estivating snails (data not shown). *- Significantly different from the corresponding activity in the crude extract using the Student's t-test, $\mathrm{P}<0.05$. 
Table 5.2. Kinetic parameters for PP2A-type activity in crude soluble extracts from foot muscle (FM) and hepatopancreas (HP) of active and $10 \mathrm{~d}$ estivated $O$. lactea.

\begin{tabular}{|c|c|c|c|c|}
\hline & $\begin{array}{l}\text { Active FM } \\
\text { Crude Extract }\end{array}$ & $\begin{array}{l}\text { Estivated FM } \\
\text { Crude Extract }\end{array}$ & $\begin{array}{l}\text { Active HP } \\
\text { Crude Extract }\end{array}$ & $\begin{array}{l}\text { Estivated HP } \\
\text { Crude Extract }\end{array}$ \\
\hline $\begin{array}{l}\mathrm{V}_{\max }(\mathrm{mU} / \mathrm{mg} \\
\text { soluble protein })\end{array}$ & $0.52 \pm 0.03$ & $0.32 \pm 0.01 *$ & $0.74 \pm 0.07$ & $0.55 \pm 0.05 *$ \\
\hline $\begin{array}{l}\mathrm{K}_{\mathrm{m}} \text { RRApTVA } \\
(\mu \mathrm{M})\end{array}$ & $64 \pm 9$ & $97 \pm 11^{*}$ & $72 \pm 6$ & $95 \pm 8 *$ \\
\hline $\mathrm{K}_{\mathrm{m}}$ casein $(\mu \mathrm{M})$ & $58 \pm 9$ & $74 \pm 6^{*}$ & $44 \pm 8$ & $80 \pm 11 *$ \\
\hline $\mathrm{K}_{\mathrm{m}}$ kemptide $(\mu \mathrm{M})$ & $172 \pm 15$ & $199 \pm 9$ & $182 \pm 11$ & $196 \pm 13$ \\
\hline $\begin{array}{l}\mathrm{I}_{50} \text { okadaic acid } \\
(\mathrm{nM})\end{array}$ & $0.7 \pm 0.4$ & $1.1 \pm 0.3$ & $1.0 \pm 0.4$ & $0.8 \pm 0.2$ \\
\hline $\mathrm{I}_{50}$ endothall $(\mathrm{nM})$ & $41 \pm 7$ & $53 \pm 11$ & $45 \pm 7$ & $39 \pm 7$ \\
\hline $\mathrm{I}_{50} \mathrm{NaF}(\mathrm{mM})$ & $5.4 \pm 0.9$ & $7.3 \pm 2.9$ & $10.1 \pm 3.9$ & $8.3 \pm 2.4$ \\
\hline $\mathrm{I}_{50} \mathrm{NH}_{4} \mathrm{Cl}(\mathrm{mM})$ & $35 \pm 6$ & $28 \pm 6$ & $37 \pm 5$ & $29 \pm 4$ \\
\hline $\mathrm{I}_{50} \mathrm{AMP}(\mu \mathrm{M})$ & $54 \pm 8$ & $69 \pm 11$ & $59 \pm 19$ & $48 \pm 9$ \\
\hline $\mathrm{I}_{50} \operatorname{ADP}(\mu \mathrm{M})$ & $66 \pm 10$ & $74 \pm 11$ & $87 \pm 9$ & $82 \pm 12$ \\
\hline $\mathrm{I}_{50} \mathrm{NaCl}(\mathrm{mM})$ & $248 \pm 34$ & $232 \pm 49$ & $211 \pm 21$ & $198 \pm 24$ \\
\hline $\mathrm{I}_{50}$ urea $(\mathrm{M})$ & $3.1 \pm 0.8$ & $3.6 \pm 0.4$ & $1.9 \pm 0.3$ & $2.2 \pm 0.2$ \\
\hline
\end{tabular}

Assays were conducted at $22^{\circ} \mathrm{C}$ and data are means \pm S.E.M. $\left(n=5\right.$ for $\operatorname{Vmax}$ and $K_{m}, n=3$ or $n=4$ for other parameters). Vmax and $I_{50}$ values were measured with casein as the substrate. $\mathrm{I}_{50}$ is the inhibitor concentration that reduces enzyme activity by $50 \%$. *Significantly different from the corresponding value for active snails as determined by the Student's t-test, $\mathrm{P}<0.05$. 
Table 5.3. Purification of type-2A heparin-binding phosphatase activity from active $O$.

lactea foot muscle. Data are representative of separate three purification trials from active foot muscle extracts. Similar results were obtained for purification of estivating foot muscle heparin binding type-2A phosphatase activity (data not shown). Recoverable activity was measured using casein as the substrate.

\begin{tabular}{llllll}
\hline $\begin{array}{l}\text { PP2A } \\
\text { purification } \\
\text { steps }\end{array}$ & $\begin{array}{l}\text { Total } \\
\text { protein } \\
(\mathrm{mg})\end{array}$ & $\begin{array}{l}\text { Total } \\
\text { activity } \\
(\mathrm{mU})\end{array}$ & $\begin{array}{l}\text { Specific } \\
\text { activity } \\
(\mathrm{mU} / \mathrm{mg})\end{array}$ & $\begin{array}{l}\text { Purification } \\
\text { (fold) }\end{array}$ & Yield (\%) \\
\hline Crude extract & 162 & 59 & 0.36 & - & 100 \\
$\begin{array}{c}\text { Trypsin } \\
\text { treatment }\end{array}$ & 99 & 145 & 1.45 & 4 & 246 \\
$\begin{array}{c}\text { DEAE-G25 } \\
\text { Sephadex }\end{array}$ & 25 & 132 & 5.28 & 14.7 & 224 \\
$\begin{array}{c}\text { Heparin- } \\
\text { Sepharose }\end{array}$ & 7 & 82 & 11.7 & 32.5 & 139 \\
$\begin{array}{c}\text { Sephacryl } \\
\text { S-400 }\end{array}$ & 1.0 & 32 & 32.0 & 88.9 & 54 \\
$\begin{array}{c}\text { NanoSep } \\
\text { concentration }\end{array}$ & 0.46 & 24 & 52.2 & 145 & 41 \\
$\begin{array}{c}\text { Microcystin- } \\
\text { agarose }\end{array}$ & 0.064 & 9.5 & 148 & 412 & 16 \\
\hline
\end{tabular}


Table 5.4. Kinetic parameters for two forms of microcystin-Sepharose eluted PP2A-type activity (heparin-binding and nonbinding) purified from foot muscle of active and $10 \mathrm{~d}$ estivating snails.

\begin{tabular}{lllll}
\hline & $\begin{array}{l}\text { Active } \\
\text { Heparin- } \\
\text { binding }\end{array}$ & $\begin{array}{l}\text { Estivated } \\
\text { Heparin- } \\
\text { binding }\end{array}$ & $\begin{array}{l}\text { Active } \\
\text { Heparin } \\
\text { nonbinding }\end{array}$ & $\begin{array}{l}\text { Estivated } \\
\text { Heparin } \\
\text { nonbinding }\end{array}$ \\
\hline $\mathrm{K}_{\mathrm{m}}$ RRApTVA $(\mu \mathrm{M})$ & $63 \pm 5$ & $70 \pm 6$ & $69 \pm 9$ & $101 \pm 9^{*}$ \\
$\mathrm{~K}_{\mathrm{m}}$ casein $(\mu \mathrm{M})$ & $48 \pm 9$ & $55 \pm 6$ & $49 \pm 9$ & $95 \pm 11^{*}$ \\
$\mathrm{~K}_{\mathrm{m}}$ kemptide $(\mu \mathrm{M})$ & $198 \pm 11$ & $185 \pm 12$ & $175 \pm 13$ & $191 \pm 9$ \\
$\mathrm{I}_{50}$ okadaic acid $(\mathrm{nM})$ & $1.1 \pm 0.3$ & $0.9 \pm 0.2$ & $1.2 \pm 0.2$ & $0.6 \pm 0.1^{*}$ \\
$\mathrm{I}_{50}$ endothall $(\mathrm{nM})$ & $43 \pm 6$ & $52 \pm 6$ & $46 \pm 4$ & $33 \pm 2^{*}$ \\
\hline
\end{tabular}

Assays were conducted under optimum conditions at $22^{\circ} \mathrm{C}$ with casein substrate. Data are means \pm S.E.M., $n=3$. *- Significantly different from the corresponding value for active snails using the Student's t-test, $\mathrm{P}<0.05$. 
Table 5.5. Kinetic parameters for PP2B activity recovered from crude soluble hepatopancreas extracts of active and $10 \mathrm{~d}$ estivated snails.

\begin{tabular}{lll}
\hline & Active & Estivated \\
\hline $\mathrm{V}_{\max }(\mathrm{mU} / \mathrm{mg}$ soluble protein) & $0.057 \pm 0.016$ & $0.065 \pm 0.014$ \\
$\mathrm{~K}_{\mathrm{m}}$ RII peptide $(\mu \mathrm{M})$ & $86 \pm 9$ & $132 \pm 21^{*}$ \\
$\mathrm{~K}_{\mathrm{m}}$ casein $(\mu \mathrm{M})$ & $175 \pm 13$ & $235 \pm 24^{*}$ \\
$\mathrm{~K}_{\mathrm{a}} \mathrm{CaCl}_{2}(\mathrm{mM})$ & $2.2 \pm 0.3$ & $3.1 \pm 0.4^{*}$ \\
$\mathrm{~K}_{\mathrm{a}}$ calmodulin $(\mathrm{nM})$ & $15 \pm 2$ & $13 \pm 2$ \\
$\mathrm{~K}_{\mathrm{a}}$ ascorbic acid $(\mathrm{mM})$ & $1.8 \pm 0.5$ & $2.4 \pm 0.7$ \\
$\mathrm{I}_{50}$ cypermethrin $(\mathrm{nM})$ & $1.8 \pm 0.5$ & $2.4 \pm 0.7$ \\
\hline
\end{tabular}

Assays were under optimal assay conditions at $22^{\circ} \mathrm{C}$ with RII peptide as the substrate (except for $\mathrm{K}_{\mathrm{m}}$ casein). Data are means \pm S.E.M., $\mathrm{n}=3$. *- Significantly different from the corresponding value for active snails using the Student's $t$-test, $\mathrm{P}<0.05$. 
Table 5.6. Purification of type-2B protein phosphatase from hepatopancreas of active $O$. lactea. Data shown is representative of two purification trials. Recoverable activity was measured using RII peptide.

\begin{tabular}{llllll}
\hline Purification steps & $\begin{array}{l}\text { Total } \\
\text { protein } \\
(\mathrm{mg})\end{array}$ & $\begin{array}{l}\text { Total } \\
\text { activity } \\
(\mathrm{mU})\end{array}$ & $\begin{array}{l}\text { Specific } \\
\text { activity } \\
(\mathrm{mU} / \mathrm{mg})\end{array}$ & $\begin{array}{l}\text { Purification } \\
\text { (fold) }\end{array}$ & $\begin{array}{l}\text { Yield } \\
(\%)\end{array}$ \\
\hline Crude extract & 1124 & 88 & 0.078 & - & 100 \\
$\begin{array}{c}\text { DEAE-G25 } \\
\begin{array}{c}\text { Sephadex } \\
\text { Heparin-Sepharose }\end{array}\end{array}$ & 504 & 51 & 0.101 & 1.3 & 58 \\
$\begin{array}{c}\text { Sephacryl S-400 } \\
\begin{array}{c}\text { Sephose } \\
\text { concentration }\end{array}\end{array}$ & 46 & 44 & 0.242 & 3.1 & 50 \\
$\begin{array}{c}\text { Calmodulin- } \\
\text { Sepharose }\end{array}$ & 0.45 & 6 & 0.456 & 5.8 & 24 \\
\hline
\end{tabular}


Table 5.7. Kinetic parameters for PP2C-type activity from crude soluble extracts of foot muscle (FM) and hepatopancreas (HP) from active and $10 \mathrm{~d}$ estivated $O$. lactea.

\begin{tabular}{lllll}
\hline & $\begin{array}{l}\text { Active FM } \\
\text { Crude Extract }\end{array}$ & $\begin{array}{l}\text { Estivated FM } \\
\text { Crude Extract }\end{array}$ & $\begin{array}{l}\text { Active HP } \\
\text { Crude Extract }\end{array}$ & $\begin{array}{l}\text { Estivated HP } \\
\text { Crude Extract }\end{array}$ \\
\hline $\begin{array}{l}\mathrm{V}_{\text {max }}(\mathrm{mU} / \mathrm{mg} \\
\text { soluble protein })\end{array}$ & $0.15 \pm 0.03$ & $0.10 \pm 0.02^{*}$ & $0.22 \pm 0.04$ & $0.36 \pm 0.05^{*}$ \\
$\begin{array}{l}\mathrm{K}_{\mathrm{m}} \mathrm{RRApTVA} \\
(\mu \mathrm{M})\end{array}$ & $16 \pm 3$ & $19 \pm 4$ & $26 \pm 5$ & $14 \pm 3^{*}$ \\
$\mathrm{~K}_{\mathrm{m}}$ casein $(\mu \mathrm{M})$ & $26 \pm 4$ & $22 \pm 6$ & $25 \pm 2$ & $16 \pm 3^{*}$ \\
$\mathrm{~K}_{\mathrm{a}} \mathrm{MgCl}_{2}(\mathrm{mM})$ & $0.9 \pm 0.4$ & $1.2 \pm 0.3$ & $2.3 \pm 0.2$ & $1.9 \pm 0.3$ \\
$\mathrm{~K}_{\mathrm{a}} \mathrm{MnCl}_{2}(\mathrm{mM})$ & $\mathrm{NA}$ & $\mathrm{NA}$ & $0.49 \pm 0.07$ & $0.33 \pm 0.05^{*}$ \\
$\mathrm{I}_{50} \mathrm{NaF}(\mathrm{mM})$ & $21 \pm 5$ & $16 \pm 5$ & $23 \pm 6$ & $29 \pm 4$ \\
$\mathrm{I}_{50} \mathrm{NaCl}(\mathrm{mM})$ & $457 \pm 45$ & $399 \pm 72$ & $554 \pm 61$ & $660 \pm 76$ \\
$\mathrm{I}_{50} \mathrm{urea}(\mathrm{M})$ & $2.4 \pm 0.2$ & $3.3 \pm 0.3^{*}$ & $2.6 \pm 0.3$ & $2.5 \pm 0.2$ \\
\hline
\end{tabular}

Assays were conducted at optimum conditions at $22^{\circ} \mathrm{C}$ with RRApTVA as the substrate (except for $K_{m}$ casein). Data are means \pm S.E.M., $n=4$ for $V_{\max }$ and $K_{m}$ data and $n=3$ for other parameters. *- Significantly different from the corresponding value for active snails using the Student's t-test, $\mathrm{P}<0.05$. 
Table 5.8. Purification of active type-2C protein phosphatase activity from $O$. lactea foot muscle. Data shown is representative of three purification trials; similar results were obtained for a single trial for PP2C from estivating extracts (data not shown). Recoverable activity was measured using casein as substrate.

\begin{tabular}{|c|c|c|c|c|c|}
\hline Purification steps & $\begin{array}{l}\text { Total } \\
\text { protein } \\
(\mathrm{mg})\end{array}$ & $\begin{array}{l}\text { Total } \\
\text { activity } \\
(\mathrm{mU})\end{array}$ & $\begin{array}{l}\text { Specific } \\
\text { activity } \\
(\mathrm{mU} / \mathrm{mg})\end{array}$ & $\begin{array}{l}\text { Purification } \\
\text { (fold) }\end{array}$ & $\begin{array}{l}\text { Yield } \\
(\%)\end{array}$ \\
\hline Crude extract & 188 & 21.6 & 0.115 & - & 100 \\
\hline $\begin{array}{r}\text { DEAE-G25 } \\
\text { Sephadex }\end{array}$ & 105 & 14.8 & 0.141 & 1.2 & 69 \\
\hline Heparin-Sepharose & 44 & 9 & 0.204 & 1.8 & 43 \\
\hline Sephacryl S-400 & 5 & 6 & 1.20 & 10.4 & 29 \\
\hline $\begin{array}{l}\text { NanoSep } \\
\text { concentration }\end{array}$ & 1.26 & 4 & 3.17 & 27.5 & 19 \\
\hline $\begin{array}{l}\text { Cibacron Blue- } \\
\text { Sepharose }\end{array}$ & 0.059 & 1.7 & 28.8 & 250 & 8 \\
\hline
\end{tabular}


Table 5.9. Kinetic parameters for PTP activity from crude soluble extracts of foot muscle (FM) and hepatopancreas (HP) from active and $10 \mathrm{~d}$ estivated $O$. lactea.

\begin{tabular}{|c|c|c|c|c|}
\hline & $\begin{array}{l}\text { Active FM } \\
\text { Crude Extract }\end{array}$ & $\begin{array}{l}\text { Estivated FM } \\
\text { Crude Extract }\end{array}$ & $\begin{array}{l}\text { Active HP } \\
\text { Crude Extract }\end{array}$ & $\begin{array}{l}\text { Estivated HP } \\
\text { Crude Extract }\end{array}$ \\
\hline $\begin{array}{l}\mathrm{V}_{\max }(\mathrm{mU} / \mathrm{mg} \\
\text { soluble protein }) \\
\text { vs TYR1 }\end{array}$ & $0.43 \pm 0.11$ & $0.35 \pm 0.08$ & $0.49 \pm 0.09$ & $0.43 \pm 0.10$ \\
\hline $\begin{array}{l}\mathrm{V}_{\max }(\mathrm{mU} / \mathrm{mg} \\
\text { soluble protein) } \\
\text { vs TYR2 }\end{array}$ & $0.32 \pm 0.05$ & $0.38 \pm 0.03$ & $0.29 \pm 0.06$ & $0.35 \pm 0.05$ \\
\hline $\begin{array}{l}\mathrm{V}_{\text {max }}(\mathrm{mU} / \mathrm{mg} \\
\text { soluble protein }) \\
\text { vs casein }\end{array}$ & $0.067 \pm 0.011$ & $0.079 \pm 0.018$ & $0.042 \pm 0.009$ & $0.046 \pm 0.011$ \\
\hline $\mathrm{K}_{\mathrm{m}}$ TYR1 (uM) & $106 \pm 14$ & $89 \pm 6$ & $125 \pm 12$ & $116 \pm 13$ \\
\hline $\mathrm{K}_{\mathrm{m}}$ TYR2 (uM) & $69 \pm 11$ & $74 \pm 6$ & $53 \pm 12$ & $72 \pm 8$ \\
\hline
\end{tabular}

Assays were conducted under optimal assay conditions at $22^{\circ} \mathrm{C}$. Data are means \pm S.E.M., $n=3$ for $V_{\max }$ using casein, $n=4-6$ for all other data). *- Significantly different from the corresponding value for active snails using the Student's t-test, $\mathrm{P}<0.05$. 
Table 5.10. Distribution of marker enzyme activities (shown as $\mathrm{mU} / \mathrm{gwm}$ ) recovered in cytosolic (CYT), mitochondrial (MIT) and plasma membrane (PM) subcellular fractions of $O$. lactea foot muscle.

\begin{tabular}{llll} 
& CYT & MIT & PM \\
\hline G6PDH & $127.62 \pm 13.32$ & $1.22 \pm 0.43$ & $4.98 \pm 0.62$ \\
Citrate synthase & $0.87 \pm 0.20$ & $3.75 \pm 0.52$ & NA \\
& & & \\
$\mathrm{Na}^{+} \mathrm{K}^{+}$-ATPase & $1.67 \pm 0.23$ & NA & $65.21 \pm 8.19$
\end{tabular}

Assays were conducted at $22^{\circ} \mathrm{C}$ under optimal conditions. Data are means \pm S.E.M., $n=3$ independent trials on separate samples of muscle. NA denotes negligible activity recovered. 
Figure 5.1. Purification scheme utilized to identify and distinguish different serine/threonine specific phosphatase activities from active and estivating $O$. lactea snails. Methodology was basically the same for foot muscle and hepatopancreas phosphatase purifications; results are presented and discussed for PP2B purified from hepatopancreas (foot muscle yielded poor activity), and for PP2A and PP2C purified from foot muscle. 


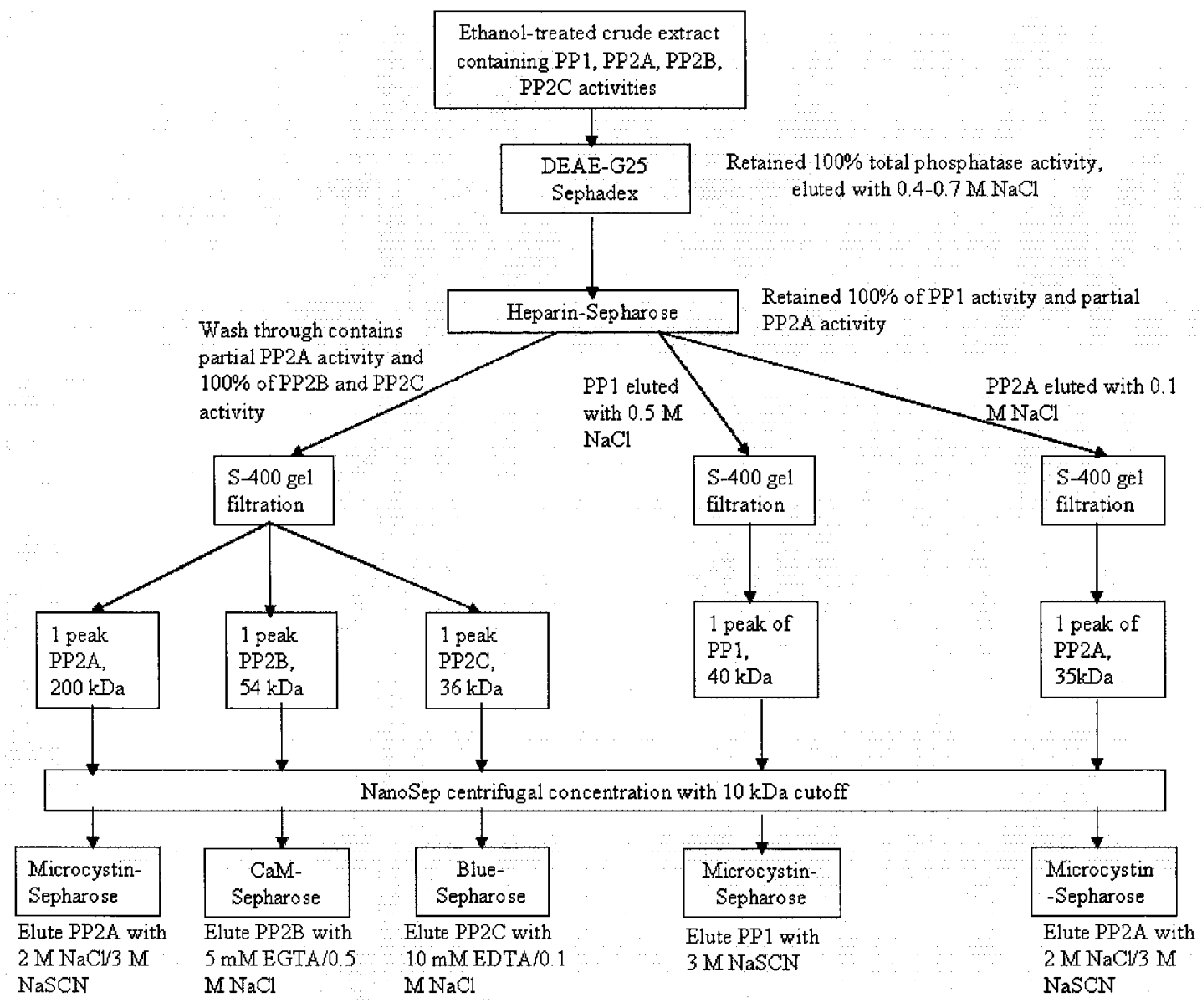


Figure 5.2. PP2A-type phosphatase activity towards different substrates recovered from crude extracts of active and $10 \mathrm{~d}$ estivated $O$. lactea foot muscle and hepatopancreas. PP2A was assayed under optimal conditions at $22^{\circ} \mathrm{C}$. FM is foot muscle, HP is hepatopancreas. Data are means \pm S.E.M, $n=5$ independent determinations. a Significantly different from corresponding activity in active foot muscle; $b$ - significantly different than corresponding activity in active hepatopancreas, as determined using the Student's t-test, $\mathrm{P}<0.05$. 


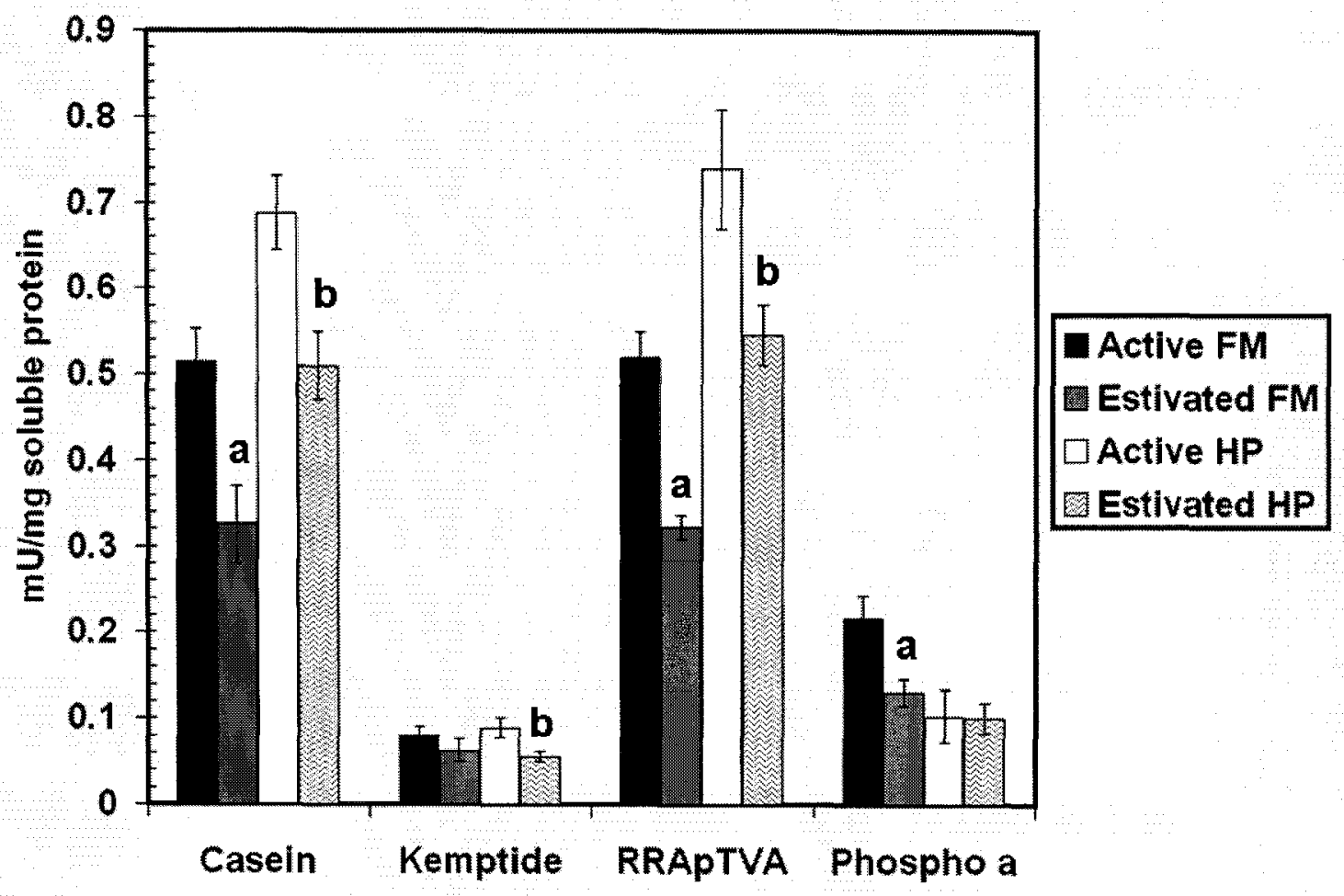


Figure 5.3. Sephacryl-S400 gel filtration elution profile of type-2A phosphatase activity recovered from $O$. lactea foot muscle from (A) trypsin-treated active extracts; (B) trypsin-treated estivated extracts; (C) untreated active extracts; and (D) untreated estivated extracts. Elution profiles are representative of $n=3$ trials each. Activity is plotted relative to the highest activity fraction. Trypsin-treated extracts typically had two peaks of 2A-type activity, labeled Peak I and Peak II, associated with protein sizes of $190 \pm 7$ $\mathrm{kDa}$ and $35 \pm 3 \mathrm{kDa}$, respectively. Untreated extracts featured a third peak (III) at $95 \pm 5$ $\mathrm{kDa}$. Molecular weight standards are shown as open triangles and are as follows: (1) thyroglobulin, $670 \mathrm{kDa}$; (2) Jack Bean urease, $545 \mathrm{kDa}$; (3) Bacillus pasteurii urease, 272 $\mathrm{kDa}$; (4) hemoglobin, $64.5 \mathrm{kDa}$; and (5) cytochrome C, $12.5 \mathrm{kDa}$. The best-fit line relating $\log \mathrm{MW}$ and elution volume is shown. 

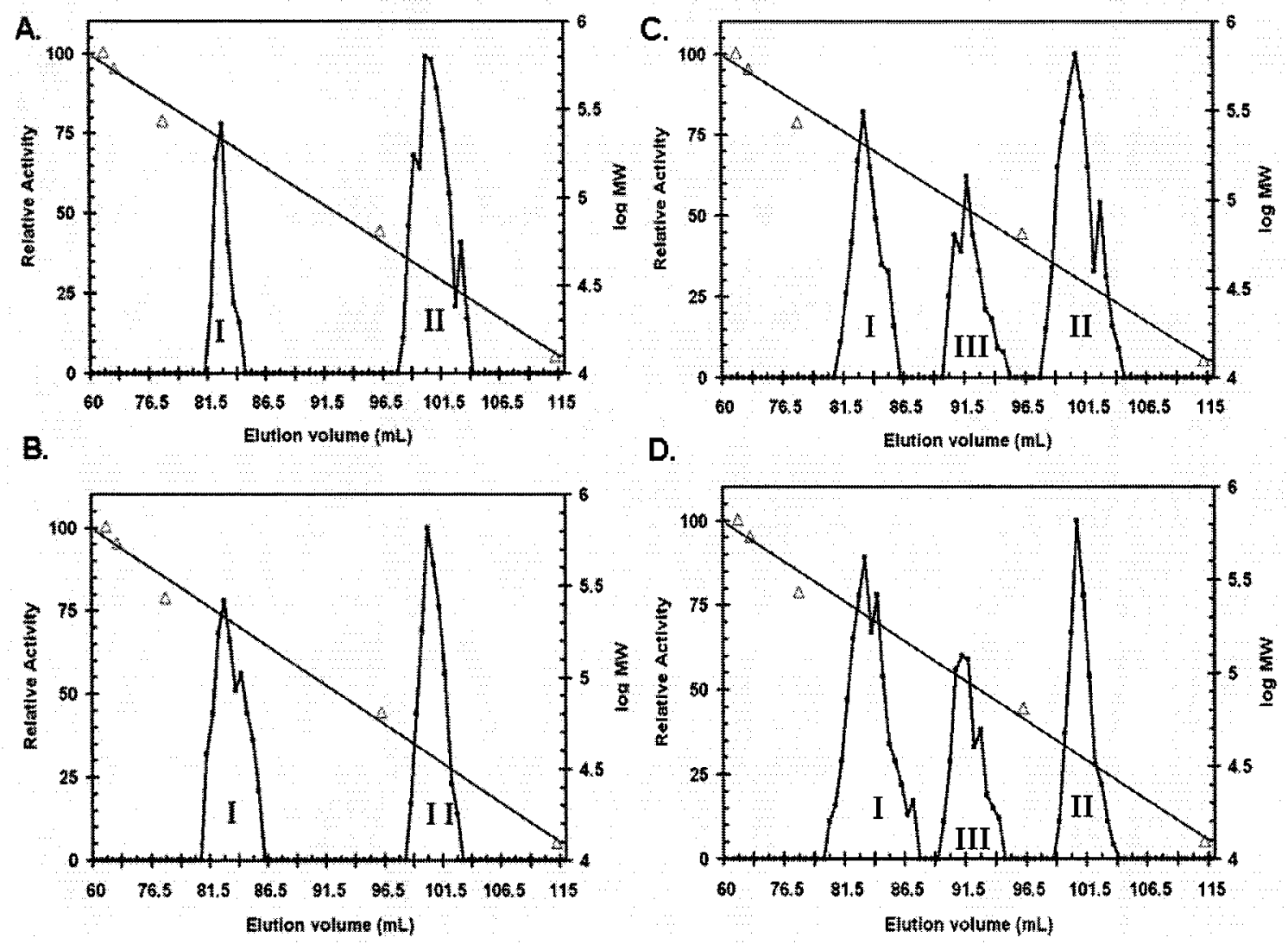
Figure 5.4. SDS-PAGE with Coomassie blue staining of samples $(15 \mu \mathrm{L})$ taken at different steps in the analysis and purification of PP2A from foot muscle of active $O$. lactea snails. Lanes represent: (A) Biorad Kaleidoscope molecular weight standards (4 $\mu \mathrm{L}$ ), (B) trypsin treated crude soluble extract, (C) pooled PP2A from DEAE-ion exchange, (D) pooled PP2A recovered in heparin-Sepharose flow-through, (E) pooled PP2A that was retained by heparin-Sepharose chromatography, (F) Sephacryl S-400 gel filtration of heparin-binding PP2A, (G) microcystin-agarose chromatography of heparinbinding PP2A, (H) Sephacryl S-400 gel filtration of heparin-nonbinding PP2A, and (I) microcystin-agarose chromatography of heparin-nonbinding PP2A. Molecular weight standards from top to bottom are myosin, $201 \mathrm{kDa}, \beta$-galactosidase, $134 \mathrm{kDa}$, bovine serum albumin, $81 \mathrm{kDa}$, carbonic anhydrase, $42 \mathrm{kDa}$, and soybean trypsin inhibitor, 32 kDa. 


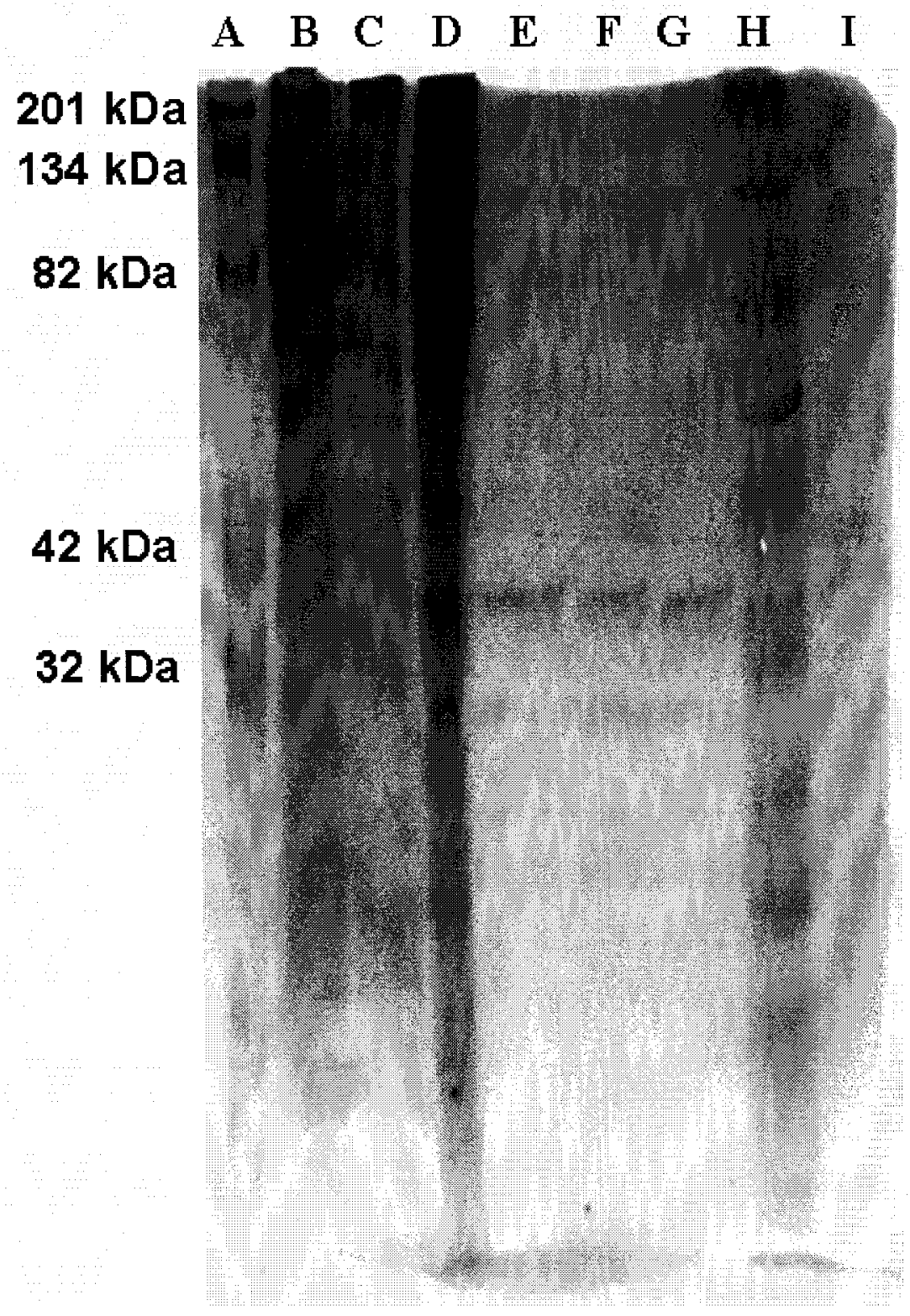


Figure 5.5. SDS-PAGE with Coomassie blue staining of samples $(15 \mu \mathrm{L})$ taken at different steps in the purification of PP2B from of active O. lactea hepatopancreas; lanes represent: (A) trypsin treated crude soluble extract, (B) DEAE-ion exchange, (C) heparinSepharose flow-through, (D) Sephacryl S-400 gel filtration, and (E) calmodulinSepharose chromatography. Kaleidoscope molecular weight standards (F) are the same as for Figure 5.4. 


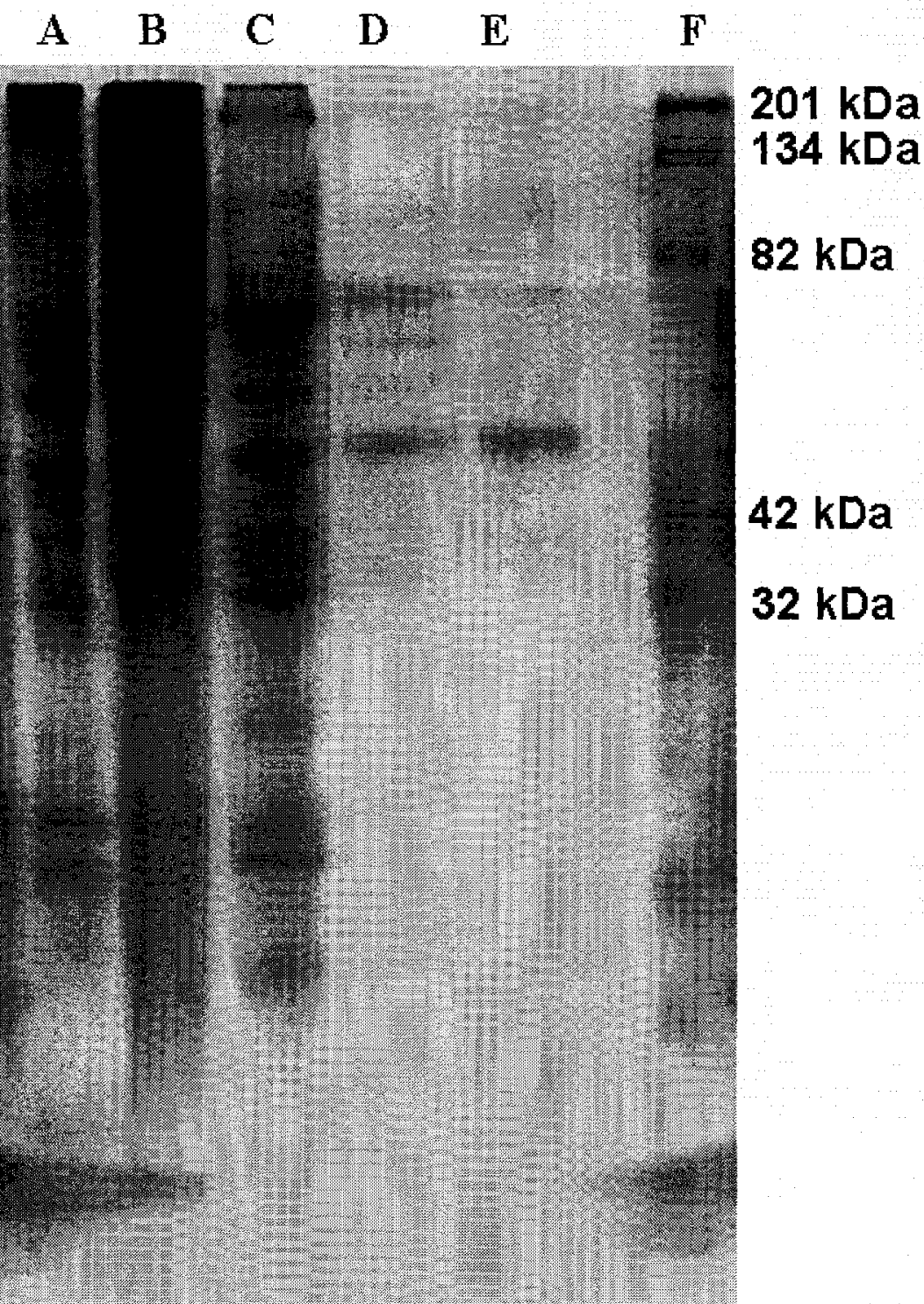


Figure 5.6. Type- $2 \mathrm{C}$ phosphatase activity, recovered from crude extracts of active and 10 d estivating $O$. lactea hepatopancreas, as a function of $\mathrm{MnCl}_{2}$ concentration. Shown are the means of independent determinations ( $\mathrm{n}=3, \pm$ S.E.M.); Ka values were calculated from individual determinations and are represented in Table 7. 


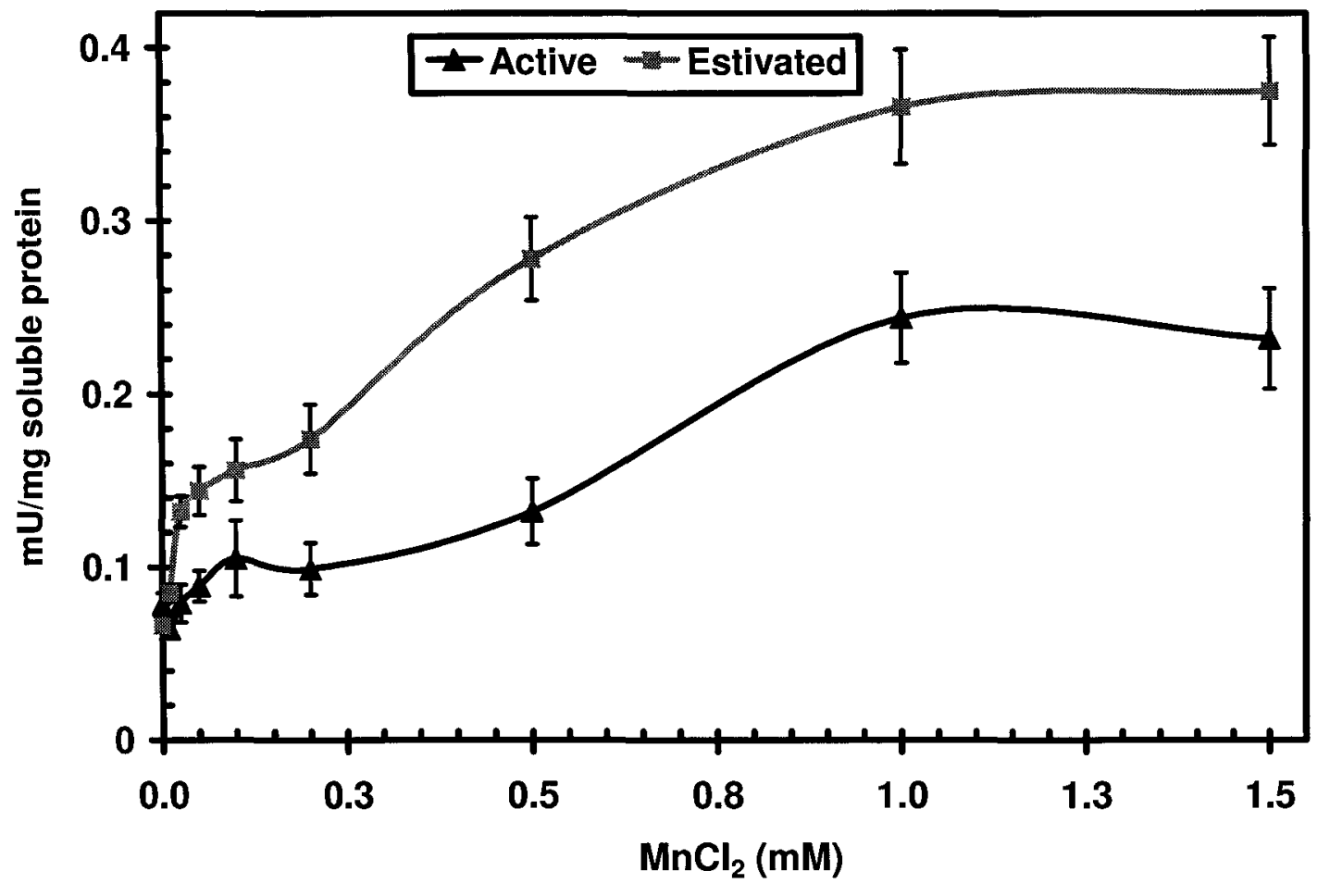


Figure 5.7. SDS-PAGE with Coomassie blue staining of samples $(15 \mu \mathrm{L})$ taken at different steps in the purification of PP2C from foot muscle of active O. lactea snails.

Lanes represent: A) trypsin treated crude soluble extract, (B) DEAE-ion exchange, (C) heparin-Sepharose flow-through, (D) Sephacryl S-400 gel filtration, (E) NanoSep centrifugal concentration, and (F) Cibacron Blue-Sepharose chromatography.

Kaleidoscope molecular weight standards (G) are the same as for Figure 5.4. 
$\begin{array}{lllllll}\text { A } & \text { B } & \text { C } & \text { D } & \text { E } & \text { F } & \text { G }\end{array}$

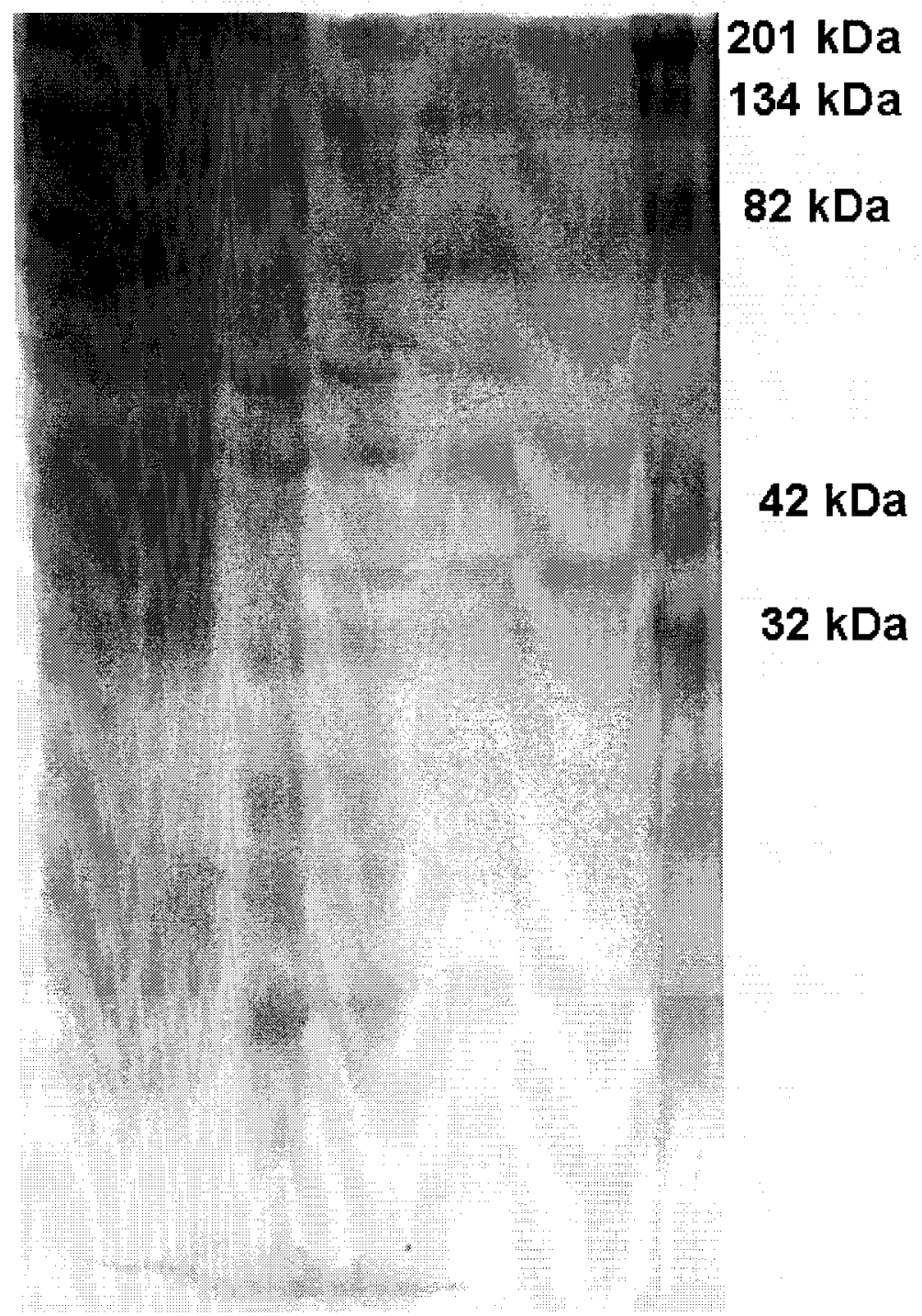


Figure 5.8. Subcellular distribution of phosphatases in foot muscle of active and estivating O. lactea: (A) type-2A, (B) type-2C, and (C) PTP phosphatase activities (Units/gram wet mass). Subcellular fractionation (CYT, cytoplasmic; MIT, mitochondrial; PM, plasma membrane) of snail extracts is described in the Materials and Methods. Phosphatases were assayed at their respective optimal conditions at $22^{\circ} \mathrm{C}$; type$2 \mathrm{~A}$ and type-2C activities were measured towards casein and PTP activity was measured using TYR1 and TYR2 peptide substrates. Data are means \pm S.E.M, $n=3$ independent determinations. a - Significantly different from the corresponding activity in extracts from active snails using the Student's t-test, $\mathrm{P}<0.05$. 

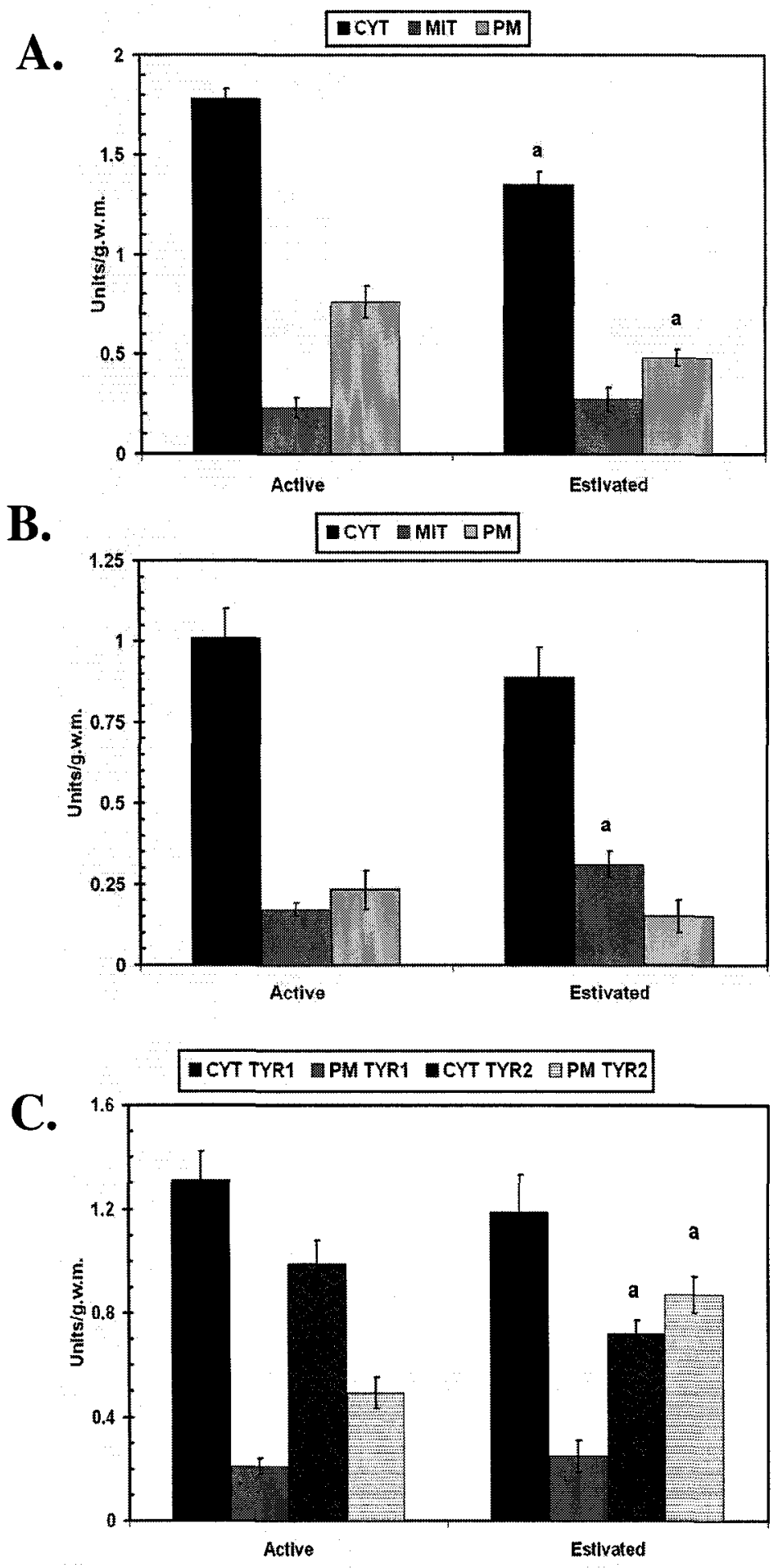


\section{Discussion}

The protein phosphatases studied herein have vital roles in regulating diverse cellular processes across living systems. PP2A can dephosphorylate enzymes involved in regulating glycolysis, glycogen metabolism, gluconeogenesis, and cholesterol and protein biosynthesis (Oliver and Shenolikar, 1998; Cohen, 1989). PP2B, commonly found in neural tissue (and often called calcineurin), has a much narrower substrate range and is not known to dephosphorylate rate-limiting enzymes in intermediary metabolism (Cohen, 1989), but its substrate specificity indicates that PP2B can regulate PP1 and PKA signaling. PP2B can dephosphorylate and inactivate physiological inhibitors of PP1, such as I-2 and DARPP-32, a $32 \mathrm{kDa}$ dopamine and cAMP regulated phosphoprotein (Mulkey et al., 1994; Herzig and Neumann, 2000). Substrates of PP2B also include the type II regulatory subunit of PKA and the CaM-dependent cAMP phosphodiesterase (Herzig and Neumann, 2000), both of which modulate PKA activity. The role of the $\mathrm{Mg}^{+2}$-dependent PP2C has not been clearly defined in animal systems, but PP2C is known to dephosphorylate and regulate proteins in stress response and growth related pathways in plants, fungus, yeast, and bacteria (Warmka et al., 2001; Ofec et al., 2003). PTPs are involved in signal transduction induced by many external stimuli, the most prominent of which are growth factors and cytokines, implicating PTP activity in the regulation of the cell cycle and the immune response (Bourdeau et al., 2005).

Given the importance and diversity of phosphatase activity in metabolic regulation, and that reversible protein phosphorylation is an established regulatory mechanism in metabolic rate depression in $O$. lactea, phosphatase activity is likely of great importance to the control of estivation in this invertebrate. Previous studies have 
shown an association of these enzymes with situations of hypometabolism. The activities of type-2 phosphatases and PTPs were differentially regulated in the estivating spadefoot toad, Scaphiopus couchii (Cowan et al., 2000; Cowan and Storey, 2001a), and type-2A and type-2C phosphatases were activated in response to subzero exposure in the cold hardy insect, Epiblema scudderiana (Pfister and Storey, 2006a). The present study represents the first analysis of phosphatase responses during estivation in an invertebrate model.

While the biochemical classification scheme for vertebrates was originally developed for vertebrate tissues, subsequent studies have established that phosphatases show typical class behaviour and are structurally conserved in both invertebrates and microorganisms. PP1, PP2 and PTP enzymes have been characterized in Drosophila melanogaster (Orgad et al., 1987), with PP2A showing 94\% identity with the rabbit counterpart (Orgad et al., 1990). Serine/threonine and tyrosine phosphatase activities have also been characterized in the insects E. scudderiana and Eurosta solidaginis (Pfister and Storey, 2002, 2006a, 2006b). A phosphatase with type-2A behaviour has been purified and studied in the brine shrimp Artemia salina (Thoen et al., 1987) and the mussel Mytilus chilensis (Rivas et al., 2000). Phosphatases with type-2B activity have been isolated and studied in the unicellular organisms Dictyostelium discoideum (Hellstern et al., 1997), Paramecium tetraurelia (Kissmehl et al., 1997), and Leishmania donovani (Banerjee et al., 1999); PP2B has also been identified in several mollusc models, primarily in neural or smooth muscle tissues (Krinks et al., 1988; Inoue et al., 1990; Sharma et al., 2003; Yamada et al., 2004). While PP2C has not been extensively studied outside of mammals, type-2C phosphatases have been characterized in yeast 
(Shiozaki and Russell, 1994), D. melanogaster (Baril and Therrien, 2006), and several microorganisms (Burns et al., 1993; Klumpp et al., 1994; Grothe et al., 1998; Da Silva et al., 1999).

The phosphatases characterized in the present study of $O$. lactea display the classic properties of phosphatases defined in other animals. Ion dependency was used to distinguish serine/threonine phosphatases in both crude extracts and purified preparations, and separated snail type- $2 \mathrm{~A}$, type- $2 \mathrm{~B}$, and type- $2 \mathrm{C}$ enzymes as ionindependent, $\mathrm{Ca}^{+2}$-dependent, and $\mathrm{Mg}^{+2}$-dependent, respectively, comparable to the situation in other species (Cohen, 1989). PP2C in hepatopancreas was also activated by $\mathrm{Mn}^{+2}$, a result that is not without precedent (Klumpp and Selke, 1998).

O. lactea phosphatases also showed expected activities towards typical substrates. Casein is an appropriate substrate for most type- 2 phosphatases, but not type-1 phosphatase (Cohen, 1989). O. lactea type-2 phosphatases generally showed substrate kinetics towards casein comparable to the kinetics observed towards other substrates tested, whereas 0 . lactea PP-1 displayed very low activity (Chapter 4). The peptide substrates used in this study yielded similar $O$. lactea phosphatase activities to those in other systems (Donella-Deana et al., 1991, 2003; Cowan and Storey, 2001a, 2001b; Pfister and Storey, 2006a, 2006b). Generally, the phosphothreonyl peptide RRApTVA gives higher type-2 phosphatase activity than the phosphoseryl peptide, kemptide (Donella-Deana et al., 1991), and both of these peptides yield highest activity from PP2A, moderate activity from PP2C, and lowest activity from PP2B, which is usually assayed with longer peptide substrates (Donella-Deana et al., 2003). In the present $O$. lactea study, PP2A showed the highest activity towards RRApTVA and kemptide, with 
RRApTVA preferred over kemptide (Figure 5.2). O. lactea PP2C had moderate activity towards RRApTVA and negligible activity towards kemptide, whereas PP2B had negligible activity towards both short peptides. PP2B required a much longer peptide substrate (RII) to yield appreciable activity. Substrate affinities $\left(K_{m}\right)$ further confirmed that the substrate preferences seen for snail phosphatases were consistent with type- 2 phosphatases in other animals.

O. lactea phosphatases also displayed typical kinetic responses to activators and inhibitors that have been identified in other systems. $\mathrm{NaF}$ and $\mathrm{Na}_{3} \mathrm{VO}_{4}$ are broad-class inhibitors of serine/threonine and tyrosine-specific phosphatases, respectively and $O$. lactea phosphatases showed typical behaviour in this regard (except that snail PP2B was sensitive to $\mathrm{Na}_{3} \mathrm{VO}_{4}$ ). Inhibitors used to distinguish between type-2 enzymes in other systems also produced characteristic responses by $O$. lactea phosphatases. Okadaic acid is a marine toxin that selectively inhibits PP1 and PP2A across many animal systems, and typically inhibits PP2A at 100-fold lower concentrations than PP1 (Cohen, 1989; Cohen et al., 1989; Shenolikar, 1994). Cypermethrin is a synthetic pyrethroid insecticide reported to inhibit PP2B (Enan and Matsumura, 1992). Endothall is a synthetic herbicide that specifically inhibits PP1 and PP2A, and is a structural analogue to cantharidin, an established inhibitor of PP1 and PP2A (Herzig and Neumann, 1997). In O. lactea, PP2A was inhibited by okadaic acid and PP2B was inhibited by cypermethrin with comparable sensitivity to that observed in other systems (Enan et al., 1992; Alexanian and Bamburg, 1999; Neumann et al., 1999; Fathi et al., 2002; Lietdke et al., 2005). However, the sensitivity to endothall by $O$. lactea $\mathrm{PP} 2 \mathrm{~A}\left(\mathrm{I}_{50}\right.$ values $33-52 \mathrm{nM}$, Table 5.4) was far greater than that of purified PP2A from Saccharomyces cerevisiae $\left(\mathrm{I}_{50}=210 \mathrm{nM}\right)$, 
Neurospora crassa $\left(\mathrm{I}_{50}=280 \mathrm{nM}\right)$, or mouse liver $\left(\mathrm{I}_{50}=970 \mathrm{nM}\right)$ (Zabrocki et al., 1995; Szoor et al., 1995, Li et al., 1993).As is typical with PP2C from other sources, type-2C from O. lactea was insensitive to the specific inhibitors studied.

The purification of $O$. lactea serine/threonine phosphatases also displayed some similarities with the phosphatases purified from other animals. Treatments with ethanol, trypsin, or ammonium sulphate increased the amount of recoverable crude PP2A activity. Such treatments are known to dissociate regulatory subunits from catalytic subunits and are particularly useful for PP1 and PP2A purification and for dissociating catalytic subunits from high molecular weight complexes (Cohen, 1989; Kamibayashi et al., 1991). Of particular interest was the gel filtration elution profile for $O$. lactea PP2A. After incubation with either trypsin or ethanol, two peaks were eluted associated with molecular weights 200 and $35 \mathrm{kDa}$, whereas gel filtration of untreated extracts showed an additional third peak associated at $95 \mathrm{kDa}$. This is interpreted as showing that trypsin or ethanol treatments can liberate the PP2A catalytic subunit from the $95 \mathrm{kDa}$ complex, but not from the $200 \mathrm{kDa}$ complex; thus, the sum of the percentages of PP2A activities in Peaks II and III in Figure 5.3 C and D is roughly equivalent to the percentage of activity in Peak 2 in Figure 5.3 A and B. Note, however, that the smallest size associated with PP2A activity from gel filtration in $O$. lactea was $35 \mathrm{kDa}$ (which was confirmed by SDSPAGE) which corresponds to purified PP2A catalytic subunits from other animals, which typically are $33-40 \mathrm{kDa}$ (Cohen, 1989). SDS-PAGE could not clearly resolve any bands corresponding to a large $200 \mathrm{kDa}$ molecular weight PP2A complex. Lanes representing the $200 \mathrm{kDa}$ PP2A from gel filtration detected many bands, and subsequent microcystin affinity chromatography only featured one band representing the $35 \mathrm{kDa}$ catalytic 
subunit. Thus, though the $200 \mathrm{kDa}$ enzyme was apparently resistant to trypsin treatment, denaturing SDS-PAGE could release the $35 \mathrm{kDa}$ catalytic subunit from the large snail PP2A structure, as is common with large molecular weight PP2A complexes from other animals (Cohen, 1989).

In the case of PP2B and PP2C, stripping treatments had no effect on recoverable activities, nor any effect on subsequent gel filtration profiles. PP2B and PP2C were associated with molecular weights of 54 and $36 \mathrm{kDa}$ (from gel filtration profiles, and confirmed by SDS-PAGE), respectively, with or without the stripping treatment. In most studies, PP2B is either unaffected or inhibited (Ohashi et al., 2004) by stripping treatments, and typical purification strategies omit ethanol precipitation, although PP2B from bovine cerebral cortex was activated with trypsin treatment (Gupta et al., 1990). PP2C exists as a monomer, and thus stripping treatments are not expected to increase recoverable activity. The molecular sizes for 0 . lactea $\mathrm{PP} 2 \mathrm{~B}$ and $\mathrm{PP} 2 \mathrm{C}$ estimated from gel filtration were $\sim 10 \%$ smaller than PP2B and PP2C catalytic subunits reported in published studies, which are typically $60 \mathrm{kDa}$ and $40 \mathrm{kDa}$, respectively (Cohen, 1989). Typically, affinity for heparin-Sepharose can be used to distinguish and separate type-1 and type-2A phosphatases since heparin is known to bind PP1 and exclude PP2A, as seen in studies with multiple mammalian tissues (Erdodi et al., 1985, 1992; Gergely et al., 1984; Neumann et al., 1999). However, O. lactea type-2A phosphatase activity was partially retained by heparin affinity chromatography. This atypical result has also been reported in solubilized-membrane phosphatases of $P$. tetraurelia (Klumpp et al., 1990) and in bovine retina (Selke et al., 1998). However, heparin chromatography still successfully resolved PP2A from PP1, as the PP2A association with heparin was 
considerably weaker than that with PP1 so that PP2A and PP1 could be eluted with $0.1 \mathrm{M}$ $\mathrm{NaCl}$ and $0.5 \mathrm{M} \mathrm{NaCl}$ bumps, respectively. Interestingly, the heparin-binding and nonheparin-binding PP2A enzymes were associated with different protein sizes (35 and 200 $\mathrm{kDa}$, respectively) recovered after the subsequent gel filtration step. A final affinity chromatography step with microcystin, calmodulin, and Cibacron Blue purified PP2A, PP2B, and PP2C enzymes, respectively; these affinity columns are well-known to bind the respective phosphatases in other animal systems and the binding behaviour of $O$. lactea phosphatases on these columns further confirmed the identity of the snail phosphatases. O. lactea PP2B and PP2C were eluted from calmodulin and Cibacron Blue columns, respectively, using similar conditions as reported in other studies, whereas snail PP2A required higher salt $(2 \mathrm{M} \mathrm{NaCl})$ for elution from microcystin than reported previously (MacDonald and Storey, 2002; Pfister and Storey, 2002). This suggests that the microcystin interaction with $O$. lactea $\mathrm{PP} 2 \mathrm{~A}$ was relatively strong.

PP2A activity was decreased in crude extracts of both tissues during estivation, and substrate affinities of the estivated form were also indicative of a less active enzyme in both tissues of estivating snails (Table 5.2). Gel filtration chromatography also showed that the relative amounts of the $200 \mathrm{kDa}$ (heparin-nonbinding) and $35 \mathrm{kDa}$ (heparinbinding) enzyme forms changed during estivation with a higher percentage of PP2A activity associated with the $200 \mathrm{kDa}$ complex during estivation (Figure 5.3). Kinetic analysis showed that the heparin-nonbinding PP2A had reduced substrate affinity, and higher inhibitor sensitivity, during estivation compared to active snails (Table 5.4). Hence, the reduced activity and lower substrate affinities of PP2A in seen in crude extracts of estivating foot muscle, compared with extracts from active snails, may be 
partially (or wholly) the result of a shift to a higher proportion of the heparin-nonbinding form of the enzyme during estivation as well as an estivation-responsive modification of the kinetic properties of the $200 \mathrm{kDa}$ enzyme.

PP2B activity was not found in foot muscle but hepatopancreas displayed substantial activity of this $\mathrm{Ca}^{2+}$ regulated phosphatase. The maximal activity of hepatopancreas PP2B did not change during estivation but elevated substrate affinities and activation constants pointed to a less active enzyme form in the estivated state. PP2C maximal velocity increased in hepatopancreas during estivation and hepatopancreas PP2C also showed greater substrate affinity and greater sensitivity to $\mathrm{Mn}^{2+}$ activation during estivation. Foot muscle PP2C activity was reduced during estivation and the enzyme also showed reduced sensitivity to urea inhibition. These data indicate that PP2C in $O$. lactea has tissue specific properties that could reflect tissue specific functions for the enzyme in active versus estivating states. PTP activities and substrate affinities did not change during estivation as assessed in crude soluble extracts.

Subcellular fractionation was used to determine if the location of phosphatase enzymes changed in active versus estivated states. No phosphatase activity was recovered in the nuclear fraction of foot muscle but estivation had a significant effect on the distribution of PP2A, PP2C and PTP activities. PP2A activity was reduced in both the CYT and PM fractions during estivation. While mainly cytosolic, PP2A is the only major type-2 phosphatase with many specific, defined nuclear substrates, including the cAMP response element-binding protein (CREB), E2F, STAT3, and c-Jun transcription factors (Zolnierowicz, 2000). Many substrates of PP2A are also cytosolic, and PP2A is also known to be targeted (via the variable size subunit) to the mitochondria (Dagda et al., 
2005), so reduced amounts of PP2A activity in these subcellular fractions are consistent with the overall decrease in type-2A activity seen in dormant snails. Type- $2 \mathrm{C}$ showed an increased proportion of total activity in the MIT fraction during estivation; while originally thought to be exclusively cytosolic, mitochondrial specific type-2C phosphatases have been observed in bovine heart (Signorile et al., 2002).

PTP activity was only recovered in the CYT and PM fractions, and no difference was observed between active and estivated snails in localization of PTP activity when assayed with TYR1. However, when PTP activity was assayed with TYR2, a significant increase in the amount of activity associated with the PM was found during estivation. TYR1 is typically a better substrate for cytoplasmic PTPs (Daum et al., 1993), and is usually used to assay overall, broad PTP activity. Conversely, TYR2 corresponds to the autophosphorylation site on the epidermal growth factor receptor (EGF receptor) and is a good substrate of PTPs that dephosphorylate membrane-associated targets that feature the SH2 (src-homology) binding site (Zhang et al., 1993; Cowan and Storey, 2001a; Pfister and Storey, 2006a, 2006b). The PTP increase observed towards TYR2 in the plasma membrane fraction from estivating snails could be related to moderating the response of membrane associated tyrosine kinase activity. PTK activity at the membrane is often associated with receptors for growth factors such as insulin, EGF, and platelet-derived growth factor; binding of these factors leads to PTK activation and downstream activation of energetically costly processes, such as cell growth and proliferation (Alonso et al., 2004). Increased membrane associated PTP activity during estivation could contribute to the maintenance of metabolic suppression by limiting and counteracting PTK activity at the membrane. Cytosolic substrates of PTP activity include the mitogen- 
activated protein kinases (MAPKs), which, when active in the phosphorylated state, lead to downstream events that signal for survival (Cowan and Storey, 2003). Increased MAPK activity has been observed in anoxic turtles, freeze tolerant frogs, hibernating ground squirrels, and anoxic snails (Greenway and Storey, 2000a, 2000b; MacDonald and Storey, 2005, 2006; Larade and Storey, 2006), which are analogous systems of hypometabolism to the estivating snail. The decrease in PTP towards TYR2 in the cytoplasm of estivating preparations could be linked to facilitating MAPK activation in dormant snails.

This study of PP2s and PTPs in $O$. lactea revealed that a general decrease in phosphatase activity was associated with the estivated condition. This is consistent with the observation that, in previous studies of regulatory enzymes in carbohydrate catabolism (reviewed in Brooks and Storey, 1997), and in previous studies in this thesis (Chapter 2 and Chapter 3, respectively), many proteins in estivating snails are maintained in highly phosphorylated (and typically less active) states, relative to enzymes in active snails. Reduced phosphatase activities would facilitate maintaining this highly phosphorylated state. Furthermore, decreased phosphatase activity, combined with decreased activity of PKA (Brooks and Storey, 1996), could be indicative of coordinated suppression of both kinases and phosphatases, which would contribute to establishing a stable hypometabolic state during dormancy. Kinetic parameters, elution profiles, and subcellular localization experiments all confirmed that these phosphatases are differentially regulated during estivation. 


\section{CHAPTER 6 \\ Protein kinases relevant to metabolic rate depression: Estivation-dependent responses in Otala lactea}




\section{Introduction}

Protein kinases have diverse regulatory functions across all eukaryotic systems and influence many cellular processes, including cellular growth, proliferation, and differentiation, inflammation, membrane transport, energy metabolism, biodegradation, biosynthesis, gene expression, and signal transduction (Stock and De Re, 2000; Cowan and Storey, 2003; Hotamisligil, 2003; MacDonald, 2004; Testa and Tsichlis, 2005; Dagon et al., 2006). Of particular relevance to the studies in this thesis, protein kinases have been shown to be important regulators of metabolic rate depression in multiple animal systems that use entry into a hypometabolic state to survive unfavorable environmental conditions. Metabolic rate depression can be achieved in part by the reversible phosphorylation of selected enzymes and functional proteins (Storey, 2002).

Reversible protein phosphorylation is known to play a role in regulating $O$. lactea metabolic depression during estivation. Prior studies have shown that several regulatory enzymes of carbohydrate catabolism displayed altered activities during estivation that could be traced to changes in their phosphorylation states (Whitwam and Storey, 1990, 1991; Brooks and Storey, 1992, 1997). In vitro studies in Chapters 2 and 3 of this thesis also implicated specific protein kinases as regulators of estivation-dependent changes in $\mathrm{Na}^{+} \mathrm{K}^{+}$-ATPase and G6PDH functioning in this model system. Whereas Chapters 4 and 5 examined the differential regulation of various protein phosphatases in estivating snails, relatively little was known previously about the role of protein kinases in $O$. lactea estivation. Protein kinase A (PKA) has been characterized from estivating snails (Brooks and Storey, 1996), but other protein kinases that are potentially relevant to metabolic rate depression had received little or no attention. 
PKG is activated by cyclic 3'5'-guanosine monophosphate (cGMP) and seems to play a central role in cellular metabolic regulation across the Phylum Mollusca. Elevated cGMP and/or PKG is known to be involved in mollusc nerve regulation (Sung et al., 2004; Gomez and Nasi, 2005), as well as in other mollusc tissues (Higgins and Greenberg, 1974; Gainey and Greenberg, 2003). In vitro studies have linked PKG with the regulation of several enzymes of carbohydrate metabolism in estivating $O$. lactea (Brooks and Storey, 1997). Other studies have implicated PKG in anoxia-induced metabolic rate depression in molluscan systems (Holwerda et al., 1981; Brooks and Storey, 1990; Larade and Storey, 2004). Given the established functions of PKG across the Mollusca, this kinase is a likely candidate to play a role in regulating the transition to the dormant state in the estivating land snail.

AMPK has a significant role in regulating the balance between energy consuming and energy producing pathways in cells. It is effectively the energy sensor of cells and is now known to a major factor in the control of various enzymes that were previously thought to be regulated primarily by allosteric actions of adenylates (ATP, ADP, AMP). When activated by elevated AMP levels (indicative of ATP depletion), AMPK stimulates ATP-generating catabolic pathways and deactivates ATP-consuming processes (Hardie and Pan, 2002). One of the best-studied targets of AMPK is acetyl-CoA carboxylase (ACC), which influences the rate of fatty acid synthesis (Davies et al., 1990). AMPK is very relevant to animals that depress metabolic rate and, therefore, must readjust their energy metabolism for long term survival. Activation of AMPK has been characterized in both vertebrate (Rider et al., 2006) and invertebrate (Pan and Hardie, 2002) systems that have been subjected to conditions that deplete cellular energy. AMPK has yet to be 
characterized in long term metabolic depression in any invertebrate model.

The phosphoinositide 3 kinase (PI3K)/protein kinase B (PKB, or Akt) signaling cascade is also known to regulate and activate cellular survival responses (Brazil et al., 2002). Several growth factors and hormones (e.g. insulin) can lead to PI3K activation, and active PI3K can phosphorylate several cellular intermediates, including PKB, which in turn regulates functions including glucose transport, protein synthesis, and survival

signaling (Hajduch et al., 2001). Activation of PKB can result in the phosphorylation of several cellular intermediates that promote cell growth and cell survival, including the mammalian target of rapamycin (mTOR), the forkhead box, class O transcription factor (FKHRL1, or FOXO 3), the pro-apoptotic factor BAD, and the p70 S6 kinase (p70S6K). The PI3K /PKB pathway is largely conserved in D. melanogaster (Oldham and Hafen, 2003), but has received relatively little study in other invertebrate systems. It remains to be clarified how PKB activity might be related to the estivating condition, in either vertebrate or invertebrate systems.

The studies presented in this chapter explore the potential roles of selected serine/threonine protein kinases (PKG, AMPK, PKB, p70S6K) in estivation of 0 . lactea, making use of a relatively new technique to assay protein kinases that involves phosphor imaging.

\section{Methods and Materials.}

\section{Animals and Chemicals.}

Otala lactea snails were raised, sacrificed, and tissues harvested as detailed in previous Chapters. Peptide substrates for protein kinases were synthesized at Queen's 
University (Kingston, ON). Antibodies (raised in rabbits) for PKB signaling proteins were obtained from Cell Signaling (Danvers, MA). Phosphocellulose (P81) paper was obtained from Whatman (VWR, Mississauga, ON). Radioactive $\left[\gamma^{32} \mathrm{P}\right]$ ATP (3000 $\mathrm{Ci} / \mathrm{mmol}$ ) was obtained from GE Healthcare Biosciences (Piscataway, NJ). All other chemicals were purchased from Sigma Chemical Co. (St. Louis, MO, USA).

\section{Sample preparation for kinase assays.}

Frozen tissue samples were initially homogenized $1: 3$ w:v in cold $\left(4^{\circ} \mathrm{C}\right)$ buffer containing 25 mM Tris-HCl, pH 7.5, $10 \%$ v:v glycerol, 50 mM NaF, 2 mM EDTA, 2 mM EGTA, and $10 \mathrm{mM}$ 2-mercaptoethanol, and optimized to include the following changes for specific protein kinases. For AMPK, 25 mM HEPES-NaOH, pH 7.0 replaced Tris$\mathrm{HCl}$. For PKG, tissues were homogenized 1:5 w:v in Tris-HCl, pH 6.8. For PKB, $20 \mathrm{mM}$ B-glycerophosphate was substituted for $\mathrm{NaF}$. In all cases, a few crystals of phenylmethylsulfonyl fluoride and $1 \mu \mathrm{L}$ of Sigma Protease Inhibitor Cocktail were added immediately prior to homogenization. Homogenates were centrifuged $10,000 \mathrm{xg}$ for 20 minutes. The supernatant was removed, desalted by low speed centrifugation through small columns of Sephadex G25 (100 $\mu \mathrm{L}$ of extract per $1 \mathrm{~mL}$ of G25) equilibrated in the appropriate buffer and used immediately for assay. The desalting step omitted for PKB because it reduced activity without affecting background. For measurements of activity in the insoluble fraction, pellets were resuspended in approximately one-third the original volume (yielding a similar protein concentration as in soluble extracts) of the appropriate homogenization buffer containing detergent (1\% v:v Brij-35 for AMPK and PKB, or 1\% v:v Triton $\mathrm{X}-100$ for $\mathrm{PKG}$ ), followed by centrifugation and desalting (except for PKB) as 
described above.

\section{Radioactive protein kinase assays.}

Protein kinase activity was determined using a radioactive assay that measured the incorporation of radiolabeled $\gamma-{ }^{32} \mathrm{P}$-ATP onto specific peptide substrates (residues that are phosphorylated are underlined). Assays were initiated by addition of $\gamma-{ }^{32} \mathrm{P}-\mathrm{ATP}$ to the appropriate reaction mixture in $500 \mu \mathrm{L}$ Eppendorf tubes. Reaction volumes were $50 \mu \mathrm{L}$ for $\mathrm{AMPK}, 60 \mu \mathrm{L}$ for $\mathrm{PKB}$, and $40 \mu \mathrm{L}$ for $\mathrm{PKG}$ and $\mathrm{p} 70 \mathrm{~S} 6 \mathrm{~K}$. The amount of crude extract used to assay AMPK, PKB, PKG, and p70S6K was optimized to contain $1 \mu \mathrm{g}, 5$ $\mu \mathrm{g}, 0.5 \mu \mathrm{g}$, and $1 \mu \mathrm{g}$ of total soluble protein per assay, respectively. Protein concentrations in crude extracts were determined using the Coomassie Blue dye binding method and the BioRad protein prepared reagent with a standard curve of bovine serum albumin. Generally, protein kinases were assayed in the presence of specific peptide inhibitors of PKA and PKC (PKA fragment 5-24 and PKC fragment 19-31, denoted as PKAi and PKCi, respectively). Zero time and zero substrate blanks were always run to account for nonspecific background signals and initial trials determined the optimal reaction time and enzyme extract used where the reaction rate remained linear.

$\underline{P K G \text { assay. }}$ PKG activity was assayed as described by S.P.J. Brooks (personal communication) and defined as cGMP-dependent activity (in the presence of PKAi) towards its peptide substrates: the generic kinase substrate Kemptide (LRRASLLG) and PKISASEFDRPLR which is specific for PKG activity (Colbran et al., 1992). Optimum assay conditions included $25 \mathrm{mM}$ Tris-HCl, $\mathrm{pH} 6.8,2 \mathrm{mM} \mathrm{MgCl} 2,10 \mu \mathrm{M}$ cGMP, 500 $\mu \mathrm{M}$ peptide substrate, $200 \mu \mathrm{M} \mathrm{Mg}^{2+}$-ATP (containing $0.5 \mu \mathrm{Ci} \gamma_{-}{ }^{32} \mathrm{P}-\mathrm{ATP}$ ), $0.5 \mu \mathrm{M}$ PKAi, 
$0.5 \mu \mathrm{M}$ PKCi, $10 \mathrm{mM} \mathrm{NaF}$, and $2 \mathrm{mM}$ EGTA. PKG reaction time was 20 minutes.

$\underline{\text { AMPK assay. }}$. Conditions were based on ideas presented in Hardie et al. (1999).

AMPK activity was defined as the AMP-dependent activity towards the peptide HMRSAMS $\underline{S}$ GLHLVKRR (SAMS, a 13-residue sequence around Ser79 on rat acetylCoA carboxylase, which is a unique and specific target for AMPK). AMPK was assayed using $25 \mathrm{mM}$ HEPES-HCl, pH 7.0, $5 \mathrm{mM} \mathrm{MgCl} 2,0.01 \%$ v:v Brij-35, $250 \mu \mathrm{M}$ AMP, 200 $\mu \mathrm{M}$ SAMS peptide, $200 \mu \mathrm{M} \mathrm{Mg}{ }^{2+}$-ATP (containing $0.5 \gamma^{-32} \mathrm{P}$-ATP), $0.5 \mu \mathrm{M}$ PKAi, 0.5 $\mu \mathrm{M}$ PKCi, $10 \mathrm{mM} \mathrm{NaF}$, and $2 \mathrm{mM}$ EGTA. AMPK reaction time was 30 minutes.

PKB assay. PKB was assayed by measuring the phosphorylation of threonine with the peptide substrate RPRAATF as described by Bozinovski et al. (2002). Assay conditions included $25 \mathrm{mM}$ Tris-NaOH, $\mathrm{pH} 7.8,15 \mathrm{mM} \mathrm{MgCl}_{2}, 100 \mu \mathrm{M}$ peptide substrate, $200 \mu \mathrm{M} \mathrm{Mg}^{2+}$-ATP (containing $0.5 \mu \mathrm{Ci} \gamma_{-}{ }^{32} \mathrm{P}$-ATP), $0.01 \%$ v:v Brij-35, 0.5 $\mu \mathrm{M}$ PKAi, $0.5 \mu \mathrm{M}$ PKCi, $35 \mathrm{mM} \beta$-glycerophosphate, and 2 mM EGTA. PKB reaction time was 60 minutes.

p70S6K assay. A downstream effect of PKB activation is phosphorylation and activation of p70S6K. The activity of p70S6K was assessed by measuring the phosphorylation of threonine with the peptide KKRNRTLTV, a substrate specific for p70S6K activity (Leighton et al., 1995), and the phosphorylation of serine with the peptide RRRL $\underline{S} S L R A$, which is acted upon by other kinases (e.g. MAPKAPK-1) but can be used to assay p70S6K in the presence of appropriate inhibitors (Leighton et al., 1995; MacDonald and Storey, 2005). Assay conditions were $30 \mathrm{mM}$ MOPS, pH 7.0, $5 \mathrm{mM}$ $\mathrm{MgCl}_{2}, 50 \mu \mathrm{M}$ peptide substrate, $100 \mu \mathrm{M} \mathrm{Mg}^{2+}$-ATP (containing $0.5 \mu \mathrm{Ci} \gamma_{-}{ }^{32} \mathrm{P}-\mathrm{ATP}$ ), 0.5 $\mu \mathrm{M}$ PKAi, $0.5 \mu \mathrm{M}$ PKCi, $10 \mathrm{mM} \mathrm{NaF}$, and $2 \mathrm{mM}$ EGTA; assays towards the nonspecific 
peptide also included the inhibitor $\mathrm{H} 7(100 \mu \mathrm{M})$, which effectively blocks MAPKAPK-1 activity (Stokoe et al., 1992).

\section{Signal detection.}

Activities were quantified based on concepts modified from Asensio and Garcia (2003). Reactions were stopped by addition of one-half reaction volume of $0.2 \mathrm{M}$ EDTA containing $0.1 \%(\mathrm{w}: \mathrm{v})$ bromophenol blue. Aliquots of $10 \mathrm{uL}$ of the stopped reaction mix were then spotted onto a penciled array drawn on P81 paper with squares of $\sim 1.2 \times 1.2$ $\mathrm{cm}$. Immediately a drop of $1 \% \mathrm{v}: \mathrm{v}$ phosphoric acid was added to each reaction spot, and then the P81 paper array was allowed to air dry under a fume hood. After 2 quick washes in $1 \% \mathrm{v}: \mathrm{v}$ phosphoric acid, subsequent phosphoric acid washing conditions were $4 \times 5$ min washes for AMPK, $5 \times 10$ min washes for PKB, and $6 \times 10$ min washes for both PKG and p70S6K.

After washing, the paper array was allowed to air dry, before being placed under saran wrap and exposed to storage phosphor screens in autoradiography cassettes. Prior to use, storage phosphor screens were stripped for at least 10 minutes using a white light box. Exposure times were $1 \mathrm{~h}$ for AMPK and p70S6K, $12 \mathrm{~h}$ for PKB, and $30 \mathrm{~min}$ for PKG. After exposure, phosphor screen signals were captured using a BioRad PhosphoImager (Hercules, CA). Quantification, background correction, and data analysis was performed using Quant One software, and relative signal density was transformed into units of activity using a standard curve of $\gamma_{-}^{32} \mathrm{P}-\mathrm{ATP}$ that was prepared using conditions similar to those for the test kinase (e.g. same spot volume, exposure time, etc.). A representative blot for AMPK assay with SAMS peptide is shown in Figure 6.1. 


\section{SDS gel electrophoresis and Western blotting}

Protein samples were prepared, loaded onto SDS-polyacrylamide gels, subjected to electrophoresis, and transferred to PDVF membranes as described previously in Chapter 2. Membranes were then blocked with non-fat dried milk in TBST at $4^{\circ} \mathrm{C}$ as described previously $(0.5 \%$ milk for 20 min for PKB and phospho-PKB, and $1 \%$ milk for $1 \mathrm{~h}$ for other proteins). Membranes were then incubated overnight at $4^{\circ} \mathrm{C}$ with the appropriate primary rabbit polyclonal antibodies (anti-FKHRL1 and anti-phospho-PKB diluted 1:2000; all other antibodies diluted 1:1000) in TBST. After 3 x 5 min washes with TBST, the membrane was then incubated with HRP-conjugated mouse anti-rabbit secondary antibody (Santa Cruz Biotechnology, diluted 1:2000 in TBST) for 1-2 $\mathrm{h}$ at room temperature, followed by 3 x 5 min washes in TBST. Bands were detected, quantified, and normalized as described previously in Chapter 2. BioRad Kaleidoscope pre-stained markers were run in one lane of each gel to assess the subunit molecular mass of the test protein.

\section{Arrhenius analysis}

Arrhenius plots were determined for protein kinases from active vs. estivating snails, as described in Chapter 2. Assay mixtures were equilibrated at the appropriate temperature for at least 10 minutes prior to initiation of the reaction by addition of Mg.ATP substrate (at the concentrations of ATP and ${ }^{32} \mathrm{P}$-ATP given above for each protein kinase). Enzyme assays were performed under $\mathrm{V}_{\max }$ conditions over a temperature range from $4-68^{\circ} \mathrm{C}$. Activation energy (Ea) was determined in $\mathrm{kJ} / \mathrm{mol}$ for linear portions 
of the relationship.

\section{AMPK effects on Acetyl-CoA Carboxylase (ACC)}

A prominent downstream target of AMPK is ACC, the rate-limiting step in fatty acid biosynthesis. ACC activity was characterized in crude soluble extracts of active and estivating snails, as well as in crude extracts that were incubated under conditions that stimulated the phosphorylation or dephosphorylation of ACC.

$\underline{\text { ACC assay. }}$ ACC was assayed in desalted crude extracts (prepared as described for AMPK activity) under optimum conditions: $25 \mathrm{mM}$ HEPES, $\mathrm{pH} 7.5,200 \mu \mathrm{M}$ acetylCoA, $1 \mathrm{mM}$ Mg.ATP, $10 \mathrm{mM} \mathrm{KHCO}_{3}, 10 \mathrm{mM}$ potassium citrate, $20 \mathrm{mM} \mathrm{MgCl} 2,100 \mu \mathrm{M}$ phosphoenolpyruvate, $100 \mu \mathrm{M}$ NADH, $1 \mathrm{U}$ each of pyruvate kinase and lactate dehydrogenase. Activity was monitored at $340 \mathrm{nM}$ using a MR5000 microplate reader (Dynatech Laboratories, Chantilly, VA) and Biolinx 2.0 software. Blanks omitted acetylCoA.

Gel filtration of $A C C$. To determine if $O$. lactea ACC existed in high molecular mass complexes, and whether these complexes could be regulated by citrate, Sephacryl S-400 gel filtration was performed as described in Chapter 4. Crude extracts were prepared as above and S-400 gel filtration columns were equilibrated overnight ( $>18 \mathrm{~h}$ ) with buffer containing $25 \mathrm{mM}$ HEPES-NaOH, pH 7.0, 20\% v:v glycerol, $50 \mathrm{mM} \mathrm{NaF}, 2$ mM EDTA, 2 mM EGTA, 10 mM 2-mercaptoethanol, and 0.04\% w:v sodium azide. For tissue extracts that were incubated with citrate, $20 \mathrm{mM}$ magnesium citrate was included in the column equilibration buffer. Tissue extracts were loaded and proteins were eluted with the same buffer (plus or minus citrate as appropriate), and $0.5 \mathrm{~mL}$ fractions were 
collected and assayed for ACC activity.

\section{In vitro incubations to promote protein phosphorylation and dephosphorylation.}

Crude soluble extracts of tissues from active and estivating snails were incubated under conditions that stimulated specific kinases and phosphatases essentially as described in Chapter 2, but with the following modifications. Incubation time was $2 \mathrm{~h}$ to assess changes in enzyme $V_{\max }$ in extracts. The effect of citrate activation of ACC was tested by incubating with $20 \mathrm{mM}$ magnesium citrate (in the presence versus absence of AMPK stimulation). Incubation conditions for AMPK and PKB were modified to stimulate (i) total phosphatase activity minus PP2A (5 $\mathrm{mM} \mathrm{CaCl}+5 \mathrm{mM} \mathrm{MgCl}_{2}+2.5$ nM okadaic acid), and (ii) PP2B/PP2C together (5 mM CaCl $2+5 \mathrm{mM} \mathrm{MgCl}_{2}+2.5 \mathrm{nM}$ okadaic acid).

\section{Results}

\section{Commentary on the P81 phoshphocellulose paper assay for protein kinases}

The use of P81 paper to bind the phosphorylated products of kinase reactions is well established and is traditionally followed by liquid scintillation counting (LSC). Recently, Asensio and Garcia (2003) described a modification of the assay for use with the phosphor imager. With this method, multiple assays can be aliquoted onto a single sheet of P81 paper (Figure 6.1) and read simultaneously as compared with the traditional P81 paper assays using LSC where one vial contains one assay spot on one paper. Two key advantages of the new method are: (1) no scintillation fluid is needed, and (2) many assay spots can be applied to the same paper 'array' and the whole array then undergoes 
the same the washing and handling conditions, compared with LSC where each paper square must be washed individually. Some limitations and claims of the method described by Asensio and Garcia (2003) were addressed and optimized in the present study. Their study reported that sample aliquots as low as $0.5 \mu \mathrm{L}$ could be spotted onto the paper with minimal error but, in practice, much better consistency was obtained with spots of 2,5 , and $10 \mu \mathrm{L}$ (10 $\mu \mathrm{L}$ was optimum, and used for the data presented). This increase in spot volume necessitated a corresponding increase in overall assay volume to 40-60 $\mu \mathrm{L}$, depending on the kinase studied. The authors suggested that the assay was well suited to monitoring activities of two or more kinases at once but in practice, I found it preferable to assay one kinase at a time, due to differences in the activities of different kinases. Thus, the conditions of assay time, washing, and length of exposure needed for a low activity kinase such as $\mathrm{PKB}$ very well result in signal that will saturate the phosphor screen for a higher activity kinase spotted on the same paper.

Background signals must also be considered when assaying crude extracts. These can arise either from test kinase activity towards small, endogenous peptides and proteins in the extract, or from the activities of other kinases that have nonspecific activity towards the test peptide. Asensio and Garcia (2003) suggested that uniform $5 \times 10$ minute phosphoric acid washes were sufficient to reduce background to acceptable levels (signal/noise $\geq 10$ ). However, I found that some kinases required more or less stringent washes. I also found that desalting the tissue extract by low speed centrifugation through G25 Sephadex columns was a simple way to can remove small, endogenous peptides from the extract before assay. However, in some cases, this did not decrease background and could actually reduce recoverable activity (ie. for PKB in this study). Some authors 
that use LSC have a short low speed centrifugation step of the assay mixture after it is stopped, and spot only the supernatant on P81 paper (Bozinovski et al., 2002). However, my initial tests found that this did not increase signal/background for $O$. lactea extracts. Low amounts of detergents are also suggested by some authors (Hardie et al., 1999); I found that $0.01 \%$ Brij-35 in the assay decreased background for lower activity kinases such as PKB and AMPK, but had no effect on PKG measurements.

Recoverable signal can be enhanced by meticulous design of peptide substrates. Substrates must be specific for the test kinase in question but also have enough basic character to bind to P81 paper, and resist the stringent washing conditions. Whereas generic peptides are economical and readily available, they are readily phosphorylated by high activity, promiscuous kinases (PKA, PKC). However, background activity from such kinases can be negated with the use of specific inhibitors (e.g. PKAi, PKCi). In this study, kinases were assayed with fairly specific peptide substrates, such as those based on phosphorylation sites of physiological substrates that were specific to the test kinases. In most cases, the peptide incorporated either increased arginine content (to facilitate binding to P81 paper) or residue substitution at key sites (to eliminate phosphorylation sites that are substrates for other kinases). Hence, protein kinase inhibitors were not absolutely required (except when assaying PKG activity towards Kemptide, which is also a suitable substrate for PKA), as background activity towards fairly specific substrates was relatively low. 


\section{PKG kinetic characterization in crude soluble extracts}

Kinetic characterization of 0 . lactea PKG revealed 1.7- and 1.9-fold increases in the maximal activity of the enzyme in crude soluble extracts from foot muscle and hepatopancreas of estivating snails, respectively, compared with active snails (Table 6.1). PKG activity was also assayed under optimum conditions over a range of temperatures $\left(4-45^{\circ} \mathrm{C}\right)$ and the effect of temperature on reaction rate is shown as an Arrhenius plot in Figure 6.2. Calculated activation energies for the linear portions of the relationship (4$35^{\circ} \mathrm{C}$ ) are shown in Table 6.1 where it can be seen that the $\mathrm{E}_{\mathrm{a}}$ values for the enzyme from estivating snails were reduced by $21 \%$ and $43 \%$ for foot muscle and hepatopancreas, respectively, compared with the values for active snails.

PKG affinities for substrate peptides were also significantly different between active and estivating states (Table 6.1). $\mathrm{K}_{\mathrm{m}}$ values for PKISASEFDRPLR and Kemptide decreased by $18 \%$ and $29 \%$, respectively, during estivation for the foot muscle enzyme; comparable decreases were $36 \%$ and $35 \%$ for hepatopancreas PKG. Hepatopancreas PKG also showed a 32\% decrease in $\mathrm{K}_{\mathrm{m}} \mathrm{Mg}$.ATP during estivation.

Substrate affinity for PKISASEFDRPLR was also tested under varying conditions of $\mathrm{pH}$ and temperature (Figure 6.3). Substrate affinity for PKISASEFDRPLR was generally the highest at $\mathrm{pH} 6.5 ; \mathrm{K}_{\mathrm{m}}$ values for PKG from active foot muscle, estivated foot muscle, and estivated hepatopancreas were $74 \%, 81 \%$, and $69 \%$ of the respective values at $\mathrm{pH} 7.0$, and $69 \%, 59 \%$, and $58 \%$ of the respective values at $\mathrm{pH} 7.8$. At $\mathrm{pH} 6.5$, $\mathrm{K}_{\mathrm{m}}$ PKISISASEFDRPLR for PKG from estivated snails was also significantly reduced by $17 \%$ for foot muscle and $34 \%$ for hepatopancreas as compared with the corresponding values in active snails (as also seen in Table 1). The same effect was seen at $\mathrm{pH} 7.0$ 
where $\mathrm{K}_{\mathrm{m}}$ values for PKG from estivating snails were $24 \%$ and $25 \%$ less than the respective values for active snails. However, at $\mathrm{pH} 7.8$, no change in $\mathrm{K}_{\mathrm{m}}$ PKISASEFDRPLR was observed between active and estivating states.

Figure 6.3B shows that temperature change between $4^{\circ} \mathrm{C}$ and $30^{\circ} \mathrm{C}$ had no effect on substrate affinity in either tissue under either active or estivating conditions. However, $\mathrm{K}_{\mathrm{m}}$ values at $40^{\circ} \mathrm{C}$ were significantly lower in all cases relative to all other temperatures tested. Differences between active and estivating conditions were observed at $22^{\circ} \mathrm{C}$ and $30^{\circ} \mathrm{C}$, with $\mathrm{K}_{\mathrm{m}}$ values reduced by $18 \%$ at $22^{\circ} \mathrm{C}$ for PKG from estivating foot muscle, and by $36 \%$ and $30 \%$ at $22^{\circ} \mathrm{C}$ and $30^{\circ} \mathrm{C}$ for the enzyme from estivating hepatopancreas, relative to corresponding values in extracts from active snails.

PKG from the tissues of estivating snails was generally more sensitive to activation by $\mathrm{Mg}^{2+}$ (34\% decrease of $\mathrm{K}_{\mathrm{a}}$ in foot muscle) and cGMP (a $36 \%$ decrease in $\mathrm{K}_{\mathrm{a}}$ in hepatopancreas) (Table 6.1). Magnesium kinetics are shown in greater detail in Figure 6.4. PKG was activated at low $\mathrm{Mg}^{2+}$ concentrations but inhibited at higher levels; the $\mathrm{I}_{50}$ value increased by $24 \%$ during estivation for foot muscle PKG. In vitro incubations that attempted to influence the phosphorylation state of PKG by exposing the enzyme to conditions that would stimulate the activities of endogenous protein kinases or protein phosphatases had no effect on the recoverable activity of PKG or the $\mathrm{K}_{\mathrm{m}}$ for PKISASEFDRPLR (data not shown).

\section{AMPK kinetic characterization in crude soluble extracts}

AMPK activity was detected in both foot muscle and hepatopancreas of $O$. lactea and in both tissues showed a strong increase in maximal activity during estivation; 
activities increased by 1.8 -fold in foot and 2.6-fold in hepatopancreas relative to values in active snails (Table 6.2). The effect of temperature on AMPK maximal activity was again assessed using Arrhenius plots over the range from 4 to $45^{\circ} \mathrm{C}$ with a linear relationship typically seen up to about $33^{\circ} \mathrm{C}$ (data not shown). The calculated $\mathrm{E}_{\mathrm{a}}$ values for the linear portion of the curve are shown in Table 6.2 and $E_{a}$ of hepatopancreas AMPK from estivating snails was significantly lower (by 43\%) as compared with the value for active snails. AMPK from both tissues of estivating snails differed in some kinetic properties. In both tissues, sensitivity to AMP activation was greater during estivation $\left(\mathrm{K}_{\mathrm{a}}\right.$ values were $27 \%$ and $25 \%$ lower for foot muscle and hepatopancreas AMPK compared with active values). $\mathrm{K}_{\mathrm{m}}$ values for SAMS peptide were also reduced by $26 \%$ and $40 \%$ for AMPK in estivating foot muscle and hepatopancreas extracts, relative to the corresponding values for active snails. Hepatopancreas AMPK was also more sensitive to inhibition by Mg.ATP during estivation ( $\mathrm{I}_{50}$ decreased by $41 \%$ ).

The effects of $\mathrm{pH}$ and temperature on AMPK substrate affinity are shown in Figure 6.5. Substrate affinity for SAMS did not differ between $\mathrm{pH} 6.5$ and $\mathrm{pH} .7 .0$ for any tissue studied, though at both $\mathrm{pH}$ values, substrate affinity in estivation was increased ( $\mathrm{K}_{\mathrm{m}}$ was reduced) when compared to active snails (Figure 6.5A). Substrate affinity was

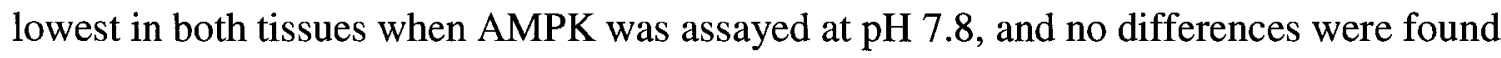
between $\mathrm{K}_{\mathrm{m}}$ values for the enzyme from active vs. estivated snails at this $\mathrm{pH} . \mathrm{K}_{\mathrm{m}}$ values for SAMS were significantly higher at low temperature $\left(4^{\circ} \mathrm{C}\right)$ than at any other temperature whereas lowest $K_{m}$ values were found at $40^{\circ} \mathrm{C}$ (Figure $6.5 B$ ); $K_{m}$ values at 10,22 , and $30^{\circ} \mathrm{C}$ were intermediate and not significantly different from each other. At the three intermediate temperatures, the $\mathrm{K}_{\mathrm{m}}$ values for SAMS of AMPK from estivating 
snails were in all cases significantly lower than the corresponding values for active snails, agreeing with the data in Table 6.2 .

When incubated under conditions that stimulated the activities of endogenous protein kinases, stimulation of PKG resulted in 2.6- and 1.3-fold increases in the Vmax of AMPK in foot muscle extracts from active and estivated snails, respectively, as compared with corresponding control extracts with no additions (Figure 6.6A). Conversely, stimulation of total protein phosphatase activity and of PP1/PP2A activity resulted in $31 \%$ and $44 \%$ decreases, respectively, in AMPK activity in extracts from active snails, and greater reductions of $61 \%$ and $64 \%$ for AMPK activity in extracts from estivated snails (Figure 6.6B). Notably, any condition that included $5 \mathrm{nM}$ okadaic acid (providing $100 \%$ inhibition of PP2A, see Chapter 5) did not influence AMPK activity.

\section{AMPK effect on ACC activity in crude soluble extracts}

ACC is a well known target of AMPK and so ACC inhibition during estivation could infer a natural role for AMPK in estivation. Table 6.3 shows that the activity of ACC was significantly reduced in crude soluble extracts from estivating snails; ACC activity was decreased to $42 \%$ and $70 \%$ of the respective values in active foot muscle and hepatopancreas. Furthermore, the $\mathrm{K}_{\mathrm{m}}$ ATP increased by 1.8-fold and 1.2-fold for ACC in estivating foot muscle and estivating hepatopancreas, respectively, whereas $\mathrm{K}_{\mathrm{a}}$ citrate increased 1.5-fold in estivating foot muscle, relative to active snail values.

To determine if the estivation-responsive changes ACC properties were related to a change in the phosphorylation state of the enzyme, crude soluble foot muscle extracts 
were incubated in vitro under conditions that stimulated the activities of endogenous protein kinases or protein phosphatases and then ACC properties were assessed (Figure 6.7). When crude extracts were stimulated under conditions that promoted AMPK action, the activity of ACC was strongly reduced to $27 \%$ for extracts of active muscle and $50 \%$ for extracts of estivated muscle of the corresponding values in untreated extracts. The $K_{m}$ ATP of ACC in active extracts also increased by 2.2-fold when AMPK was stimulated. Incubations stimulating PP2C had the opposite effect. ACC activity increased significantly by 1.2- and 2.4-fold increases in extracts from active and estivated extracts, respectively, and $\mathrm{K}_{\mathrm{m}}$ ATP decreased by $42 \%$ for the estivated enzyme. Citrate is an activator of ACC and its addition to the incubation mixture strongly increased ACC activity by 2.7 - and 7.0-fold in active and estivated extracts, respectively; however, citrate had no effect on affinity for ATP. When incubation promoting AMPK activity were conducted in the presence of citrate, the activator had no effect on the resulting ACC activity which was reduced to $32 \%$ and $45 \%$ of the values in active and estivated control incubations (virtually identical with the effects of AMPK alone). $\mathrm{K}_{\mathrm{m}}$ ATP of ACC increased by 2.1- and 1.4-fold, respectively, under these conditions but the values were not significantly different from the effects of AMPK alone. Incubations that stimulated other protein kinases and phosphatases had no effect on recoverable ACC activity or $\mathrm{K}_{\mathrm{m}}$ ATP (data not shown).

Aliquots of snail foot muscle extracts were subjected to Sephacryl S400 gel filtration (Figure 6.8) and the elution profile of ACC activity was assessed. In extracts from active snails, ACC activity eluted in two peaks of activity, labeled peak I and peak II, corresponding to $1520 \mathrm{kDa}$ and $205 \mathrm{kDa}$, respectively (Figure 6.8A). When foot 
muscle extracts were incubated under conditions that stimulated AMPK, the peak profile shifted, and only one peak (202 kDa) was found, corresponding to peak II (Figure 6.8B). However, when extracts were incubated with $20 \mathrm{mM}$ citrate, ACC activity shifted to the high molecular weight form, showing a single peak corresponding to a protein the size of $1575 \mathrm{kDa}$, similar to peak I (Figure 6.8C). Finally, when foot muscle extracts from active snails were incubated with $20 \mathrm{mM}$ citrate under conditions that stimulated AMPK activity, only one peak of ACC activity was eluted that corresponded to a protein the size of $210 \mathrm{kDa}$ (Figure 6.8D).

\section{$P K B$ kinetic characterization in crude extracts}

The maximum activity of PKB increased 2.0- and 1.7-fold in foot muscle and hepatopancreas, respectively, of estivating snails compared with the values in active animals (Table 6.4). PKB affinities for substrates also increased during estivation in hepatopancreas; the $\mathrm{K}_{\mathrm{m}}$ RPRAATF decreased by $30 \%$ and $\mathrm{K}_{\mathrm{m}} \mathrm{Mg}$.ATP decreased by $18 \%$. Incubations designed to stimulate the phosphorylation and dephosphorylation of PKB revealed that stimulating PKA elevated PKB in extracts of active snail foot muscle by 2.9 -fold (Figure 6.9A), whereas several conditions that stimulated protein phosphatases led to decreases in foot muscle PKB activity (Figure 6.9B). Stimulating total phosphatases, PP1/PP2A, total phosphatases minus PP1/2A, total phosphatases minus $\mathrm{PP} 2 \mathrm{~A}$, and $\mathrm{PP} 2 \mathrm{C}$ resulted in reductions in $\mathrm{PKB}$ activity of $81 \%, 79 \%, 57 \%, 45 \%$, and $45 \%$, respectively, in extracts from estivated foot muscle, whereas stimulating total phosphatases and PP1/2A resulted in $76 \%$ and $60 \%$ decreases in PKB activity in foot muscle extracts of active snails. In hepatopancreas, stimulation of PKA and PKG 
resulted in 1.7- and 1.6-fold increases in PKB activity in extracts from active snails (Figure 6.10A). By contrast, stimulation of total phosphatases and PP1/PP2A led to 50\% and $58 \%$ decreases, respectively, in PKB activity in active snails, and to $76 \%$ and $66 \%$ decreases in estivated animals (Figure 6.10B).

\section{Total protein and phospho-protein levels of PKB and selected targets}

In addition to analyzing PKB kinetic properties, Western blotting was used to quantify total $\mathrm{PKB}$ protein and the relative amount of phosphorylated $\mathrm{PKB}$ in foot muscle and hepatopancreas of active and estivated snails (Figure 6.11). Total protein and phosphoprotein levels of selected downstream targets of PKB were also assessed. Polyclonal anti-mouse PKB, mTOR, FKHRL1 and BAD crossreacted with snail proteins of molecular weights $60 \mathrm{kDa}, 250 \mathrm{kDa}, 110 \mathrm{kDa}$, and $20 \mathrm{kDa}$, respectively; these values were very similar to the known molecular weights of these proteins in mammals $(60 \mathrm{kDa}$, $288 \mathrm{kDa}, 100 \mathrm{kDa}, 23 \mathrm{kDa}$ ). Polyclonal antibodies for PKB targets that failed to crossreact included antibodies for the cAMP response element binding protein (CREB) and the transcription factor Nuclear Factor $\kappa B(\mathrm{NF}-\kappa \mathrm{B})$. Total protein content of PKB, mTOR, FKHRL1, and BAD did not change between active and estivating states in either tissue. However, during estivation, the level of phosphorylated PKB (Ser473), FKHRL1 (Ser 256), and BAD (Ser136) increased significantly by 1.4-, 4.2-, and 1.8-fold in foot muscle, and by 1.4-, 2.0-, and 2.0-fold in hepatopancreas. However, the phosphorylation of mTOR did not change during estivation when evaluated with either of the phosphospecific antibodies tested (Ser2448 and Ser2481).

p70S6K activity in crude soluble extracts. 
The activity of p70S6K, a downstream target of $\mathrm{PKB}$, was assayed under optimal conditions with two substrate peptides, KKRNRTLTV and RRRLSSSLRA (denoted PEP1 and PEP2 in Figure 6.12). Both peptides produced similar activities. In foot muscle, p70S6K maximal velocity towards PEP1 decreased significantly by $42 \%$ in estivation; activity towards PEP2 showed a similar pattern but was not significantly different. In hepatopancreas, p70S6K $\mathrm{V}_{\max }$ towards both substrates decreased significantly during estivation; the values with PEP1 and PEP2 were reduced by $62 \%$ and $52 \%$, respectively, relative to active snail extracts.

\section{Kinase profile in insoluble fraction}

PKG activity was the only kinase activity tested that could be recovered from the insoluble fraction of snail tissues. Activities in the insoluble fraction of foot muscle and hepatopancreas of active snails had specific activities of $454 \pm 77$ and $684 \pm 57$

$\mathrm{pmol} / \mathrm{min} / \mathrm{mg}$ protein, respectively ( $\mathrm{n}=3, \pm$ S.E.M.). Activities did not change significantly in estivating foot muscle and hepatopancreas $(512 \pm 85$ and $631 \pm 52$, $\mathrm{pmol} / \mathrm{min} / \mathrm{mg}$ protein, respectively). Values for $\mathrm{K}_{\mathrm{m}}$ PKISASEFDRPLR and $\mathrm{K}_{\mathrm{a}} \mathrm{cGMP}$ were characterized in hepatopancreas $(276 \pm 45 \mu \mathrm{M}$ and $1.8 \pm 0.5 \mu \mathrm{M}$, respectively), and did not change significantly during estivation. 
Table 6.1. Kinetic parameters for cGMP-dependent protein kinase from foot muscle and hepatopancreas of active and $10 \mathrm{~d}$ estivated $O$. lactea.

\begin{tabular}{|l|l|l|l|l|}
\hline \multirow{2}{*}{} & \multicolumn{2}{|c|}{ Foot muscle } & \multicolumn{2}{c|}{ Hepatopancreas } \\
\cline { 2 - 5 } & Active & Estivated & Active & Estivated \\
\hline $\begin{array}{l}\mathrm{V}_{\max }(\mathrm{pmol} / \mathrm{min} / \mathrm{mg} \\
\text { protein })\end{array}$ & $1567 \pm 123$ & $2678 \pm 286^{*}$ & $2816 \pm 313$ & $5432 \pm 654^{* *}$ \\
\hline $\begin{array}{l}\mathrm{K}_{\mathrm{m}} \text { PKISASEFDRPLR } \\
(\mu \mathrm{M})\end{array}$ & $176 \pm 13$ & $144 \pm 9^{*}$ & $211 \pm 27$ & $135 \pm 19^{* *}$ \\
\hline $\mathrm{K}_{\mathrm{m}} \mathrm{Kemptide}(\mu \mathrm{M})$ & $122 \pm 13$ & $86 \pm 9^{*}$ & $143 \pm 16$ & $92 \pm 9^{* *}$ \\
\hline $\mathrm{K}_{\mathrm{m}} \mathrm{Mg} \cdot \mathrm{ATP}(\mu \mathrm{M})$ & $87 \pm 11$ & $94 \pm 9$ & & \\
\hline $\mathrm{K}_{\mathrm{a}} \mathrm{cGMP}(\mu \mathrm{M})$ & $1.6 \pm 0.3$ & $1.5 \pm 0.2$ & $1.1 \pm 0.2$ & $0.7 \pm 0.1^{*}$ \\
\hline $\mathrm{K}_{\mathrm{a}} \mathrm{Mg}^{2+}(\mu \mathrm{M})$ & & & $57 \pm 6$ & $39 \pm 4^{*}$ \\
& $648 \pm 79$ & $429 \pm 45^{*}$ & $354 \pm 52$ & $305 \pm 41$ \\
\hline $\mathrm{I}_{50} \mathrm{Mg}^{2+}(\mathrm{mM})$ & $3.2 \pm 0.2$ & $4.1 \pm 0.3^{*}$ & $3.7 \pm 0.7$ & $4.4 \pm 0.8$ \\
& & & $37.7 \pm 5.3$ & $26.8 \pm 2.5^{* *}$ \\
\hline $\mathrm{E}_{\mathrm{a}}(\mathrm{KJ} / \mathrm{mol})$ & $38.1 \pm 2.4$ & $30.0 \pm 2.5^{*}$ & & \\
\hline
\end{tabular}

Assays were conducted at $22^{\circ} \mathrm{C}$ (except for Arrhenius plots) and data are means \pm S.E.M. ( $n=3-5$ independent determinations on separate preparations). Kinetic constants were determined under optimal assay conditions at pH 6.8 with PKIS $\underline{S} A$ SEFDRPLR as the substrate (except for $\mathrm{K}_{\mathrm{m}}$ Kemptide). Significance testing used the Student's t-test. *Significantly different from the corresponding value for active snails, $\mathrm{P}<0.05 ; *_{\text {- }}$ $\mathrm{P}<0.01$. 
Table 6.2. Kinetic parameters for AMP-activated protein kinase from foot muscle and hepatopancreas of active and $10 \mathrm{~d}$ estivated $O$. lactea.

\begin{tabular}{|c|c|c|c|c|}
\hline & \multicolumn{2}{|c|}{ Foot muscle } & \multicolumn{2}{|c|}{ Hepatopancreas } \\
\hline & Active & Estivated & Active & Estivated \\
\hline $\begin{array}{l}\mathrm{V}_{\max }(\mathrm{pmol} / \mathrm{min} / \mathrm{mg} \\
\text { protein })\end{array}$ & $473 \pm 17$ & $845 \pm 20^{* *}$ & $233 \pm 19$ & $599 \pm 22 * *$ \\
\hline $\mathrm{K}_{\mathrm{m}}$ SAMS $(\mu \mathrm{M})$ & $64 \pm 6$ & $47 \pm 3 *$ & $70 \pm 5$ & $42 \pm 4 * *$ \\
\hline $\mathrm{K}_{\mathrm{m}} \mathrm{Mg} \cdot \mathrm{ATP}(\mu \mathrm{M})$ & $56 \pm 9$ & $63 \pm 8$ & $87 \pm 11$ & $93 \pm 12$ \\
\hline $\mathrm{K}_{\mathrm{a}} \mathrm{AMP}(\mu \mathrm{M})$ & $126 \pm 13$ & $91 \pm 10^{*}$ & $126 \pm 7$ & $95 \pm 10^{*}$ \\
\hline $\mathrm{K}_{\mathrm{a}} \mathrm{Mg}^{2+}(\mathrm{mM})$ & $1.5 \pm 0.4$ & $1.9 \pm 0.3$ & $1.1 \pm 0.3$ & $1.2 \pm 0.2$ \\
\hline $\mathrm{I}_{50} \mathrm{Mg} \cdot \mathrm{ATP}(\mathrm{mM})$ & $2.3 \pm 0.4$ & $2.7 \pm 0.5$ & $3.2 \pm 0.4$ & $1.9 \pm 0.2^{* *}$ \\
\hline $\mathrm{E}_{\mathrm{a}}(\mathrm{KJ} / \mathrm{mol})$ & $40.1 \pm 8.4$ & $32.2 \pm 6.5$ & $32.7 \pm 3.3$ & $18.8 \pm 2.5^{* *}$ \\
\hline
\end{tabular}

Assays of AMPK activity towards SAMS were conducted at $22^{\circ} \mathrm{C}$ (except for Arrhenius plots) and data are means \pm S.E.M. $(n=3-5$ independent determinations on separate preparations). Kinetic constants were determined under optimal assay conditions at $\mathrm{pH}$ 7.0. Significance testing used the Student's t-test. *- Significantly different from the corresponding value for active snails, $\mathrm{P}<0.05 ; * *$ - $\mathrm{P}<0.01$. 
Table 6.3. Kinetic parameters for acetyl-CoA carboxylase from foot muscle and hepatopancreas of active and $10 \mathrm{~d}$ estivated $O$. lactea.

\begin{tabular}{|l|l|l|l|l|}
\hline & \multicolumn{2}{|c|}{ Foot muscle } & \multicolumn{2}{c|}{ Hepatopancreas } \\
\cline { 2 - 5 } & \multicolumn{1}{|c|}{ Active } & Estivated & Active & Estivated \\
\hline $\begin{array}{l}\mathrm{V}_{\text {max }}(\mathrm{nmol} / \mathrm{min} / \mathrm{mg} \\
\text { protein })\end{array}$ & $198 \pm 15$ & $83 \pm 9^{*}$ & $203 \pm 13$ & $142 \pm 23^{*}$ \\
\hline $\mathrm{K}_{\mathrm{m}}$ acetyl-CoA $(\mu \mathrm{M})$ & $54 \pm 2$ & $87 \pm 5$ & $51 \pm 7$ & $66 \pm 8$ \\
\hline $\mathrm{K}_{\mathrm{m}} \mathrm{Mg.ATP}(\mu \mathrm{M})$ & $83 \pm 10$ & $150 \pm 15^{*}$ & $67 \pm 5$ & $82 \pm 4^{*}$ \\
\hline $\mathrm{K}_{\mathrm{a}}$ citrate $(\mathrm{mM})$ & & & & \\
& $1.0 \pm 0.1$ & $1.5 \pm 0.2^{*}$ & $0.8 \pm 0.1$ & $0.9 \pm 0.2$ \\
\hline
\end{tabular}

Assays were conducted at $22^{\circ} \mathrm{C}$ and data are means \pm S.E.M. $(n=4$ independent determinations on separate preparations). Kinetic constants were determined under optimal assay conditions. Significance testing used the Student's t-test. *- Significantly different from the corresponding value for active snails, $\mathrm{P}<0.05$. 
Table 6.4. Kinetic parameters for PKB from foot muscle and hepatopancreas of active and $10 \mathrm{~d}$ estivated $O$. lactea.

\begin{tabular}{|l|l|l|l|l|}
\hline & \multicolumn{2}{|c|}{ Foot muscle } & \multicolumn{2}{c|}{ Hepatopancreas } \\
\cline { 2 - 5 } & \multicolumn{1}{|c|}{ Active } & \multicolumn{1}{c|}{ Estivated } & Active & Estivated \\
\hline $\begin{array}{l}\mathrm{V}_{\max }(\mathrm{pmol} / \mathrm{min} / \mathrm{mg} \\
\text { protein) }\end{array}$ & $35 \pm 7$ & $69 \pm 9^{*}$ & $27 \pm 6$ & $46 \pm 6^{*}$ \\
\hline $\mathrm{K}_{\mathrm{m}}$ RPRAATF $(\mu \mathrm{M})$ & $2.4 \pm 0.6$ & $3.1 \pm 0.7$ & $3.0 \pm 0.4$ & $2.1 \pm 0.3^{*}$ \\
\hline $\mathrm{K}_{\mathrm{m}} \mathrm{Mg} . \mathrm{ATP}(\mu \mathrm{M})$ & $45 \pm 6$ & $56 \pm 8$ & $68 \pm 2$ & $56 \pm 4^{*}$ \\
\hline $\mathrm{K}_{\mathrm{a}} \mathrm{Mg}^{2+}(\mathrm{mM})$ & & & & \\
& $5.2 \pm 1.1$ & $6.2 \pm 0.9$ & $5.8 \pm 1.3$ & $5.8 \pm 0.4$ \\
\hline
\end{tabular}

Assays of PKB activity towards RPRAATF were conducted at $22^{\circ} \mathrm{C}$. Data are means \pm S.E.M. ( $n=3$ independent determinations on separate preparations). Kinetic constants were determined under optimal assay conditions. Significance testing used the Student's t-test. *- Significantly different from the corresponding value for active snails, $\mathrm{P}<0.05$. 
Figure 6.1. Representative image of radioactive protein kinase assay captured with the BioRad PhosphoImager. Shown are two repeats of $O$. lactea foot muscle AMPK activity versus concentration of SAMS peptide $(0-250 \mu \mathrm{M})$. Details of assay conditions, washing conditions, and exposure conditions are in Methods and Materials. 


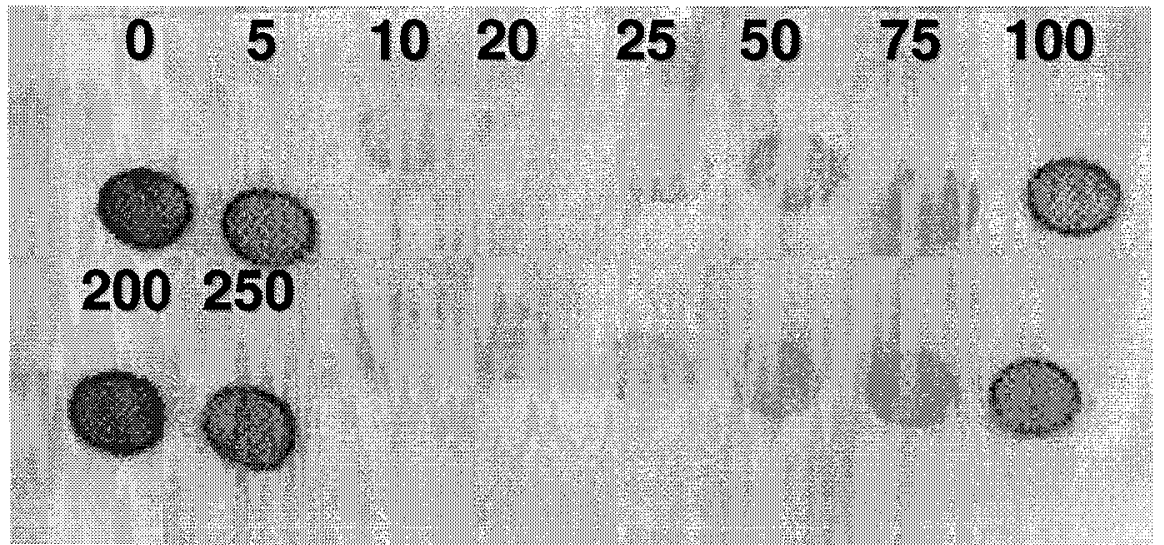


Figure 6.2. Arrhenius plots showing PKG maximal activity from O. lactea as a function of temperature (Kelvin) for (A) foot muscle and (B) hepatopancreas. Data are means \pm S.E.M, $n=3$ independent preparations of enzyme from active (ACT) and estivating (EST) snails. Assay mixtures were pre-incubated for 10 minutes in water baths set to specified temperatures prior to initiating reactions by the addition of $\mathrm{Mg}^{2+-} \mathrm{ATP}$. Assays were conducted at maximum substrate concentrations. Arrhenius activation energy $\left(\mathrm{E}_{\mathrm{A}}\right)$ was calculated from the linear part of the relationship. 


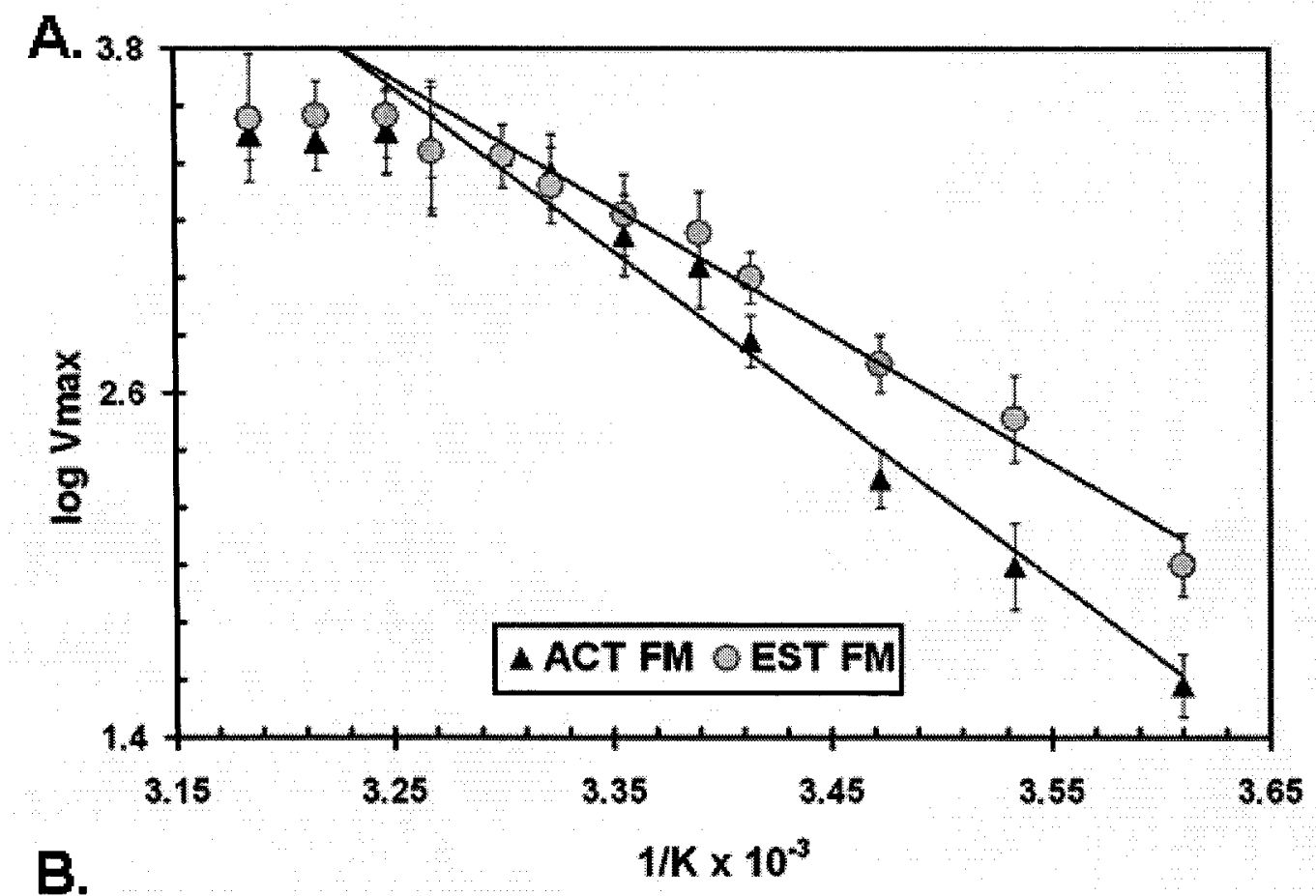

B.

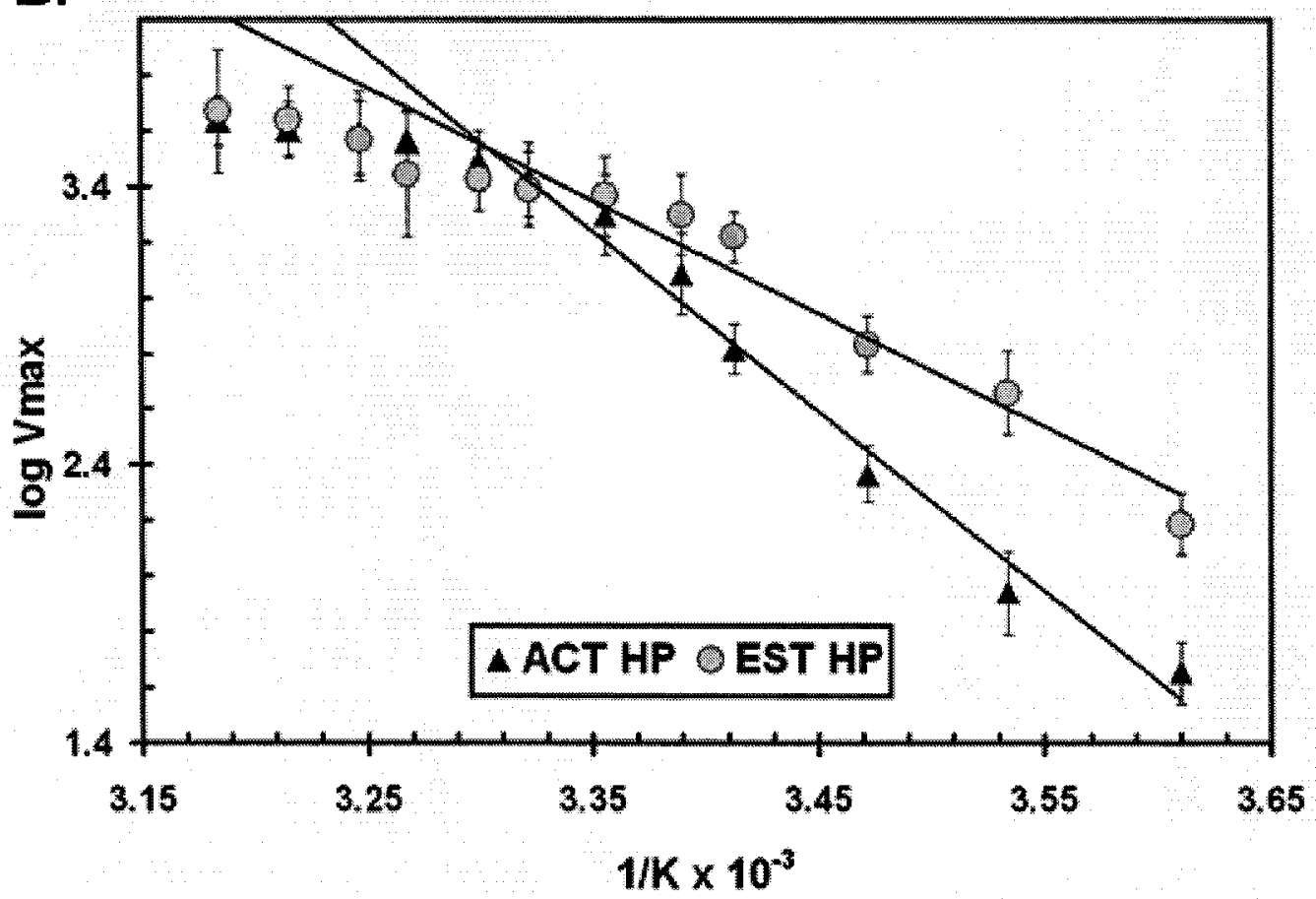


Figure 6.3. Effects of $\mathrm{pH}$ and temperature on the $\mathrm{PKG} \mathrm{K}_{\mathrm{m}}$ values for the peptide PKISASEFDRPLR for O. lactea foot muscle (FM) and hepatopancreas (HP) from active (ACT) and estivating (EST) snails. (A) For the study of $\mathrm{pH}$ effects, data are means \pm S.E.M., $n=3-4$ independent preparations of enzyme, all assayed at $22^{\circ} \mathrm{C}$. a - Significantly different than the corresponding $\mathrm{K}_{\mathrm{m}}$ for active snail $\mathrm{PKG}$ at the same $\mathrm{pH} ; \mathrm{b}$ - significantly different from the $\mathrm{K}_{\mathrm{m}}$ value for the same enzyme at all other $\mathrm{pH}$ values; $\mathrm{c}$ - significantly different from the $\mathrm{K}_{\mathrm{m}}$ value for the same enzyme at $\mathrm{pH} 6.5$ using the Student's t-test, $\mathrm{P}<0.05$. (B) For the study of temperature effects, data are means \pm S.E.M., $n=3$ independent preparations, all at optimum $\mathrm{pH}$ 6.8. a - Significantly different than the $\mathrm{K}_{\mathrm{m}}$ for the corresponding active extract PKG at same temperature; $b$ - significantly different than $K_{m}$ for the same enzyme at all other temperatures assayed determined by Student's ttest, $\mathrm{P}<0.05$. 


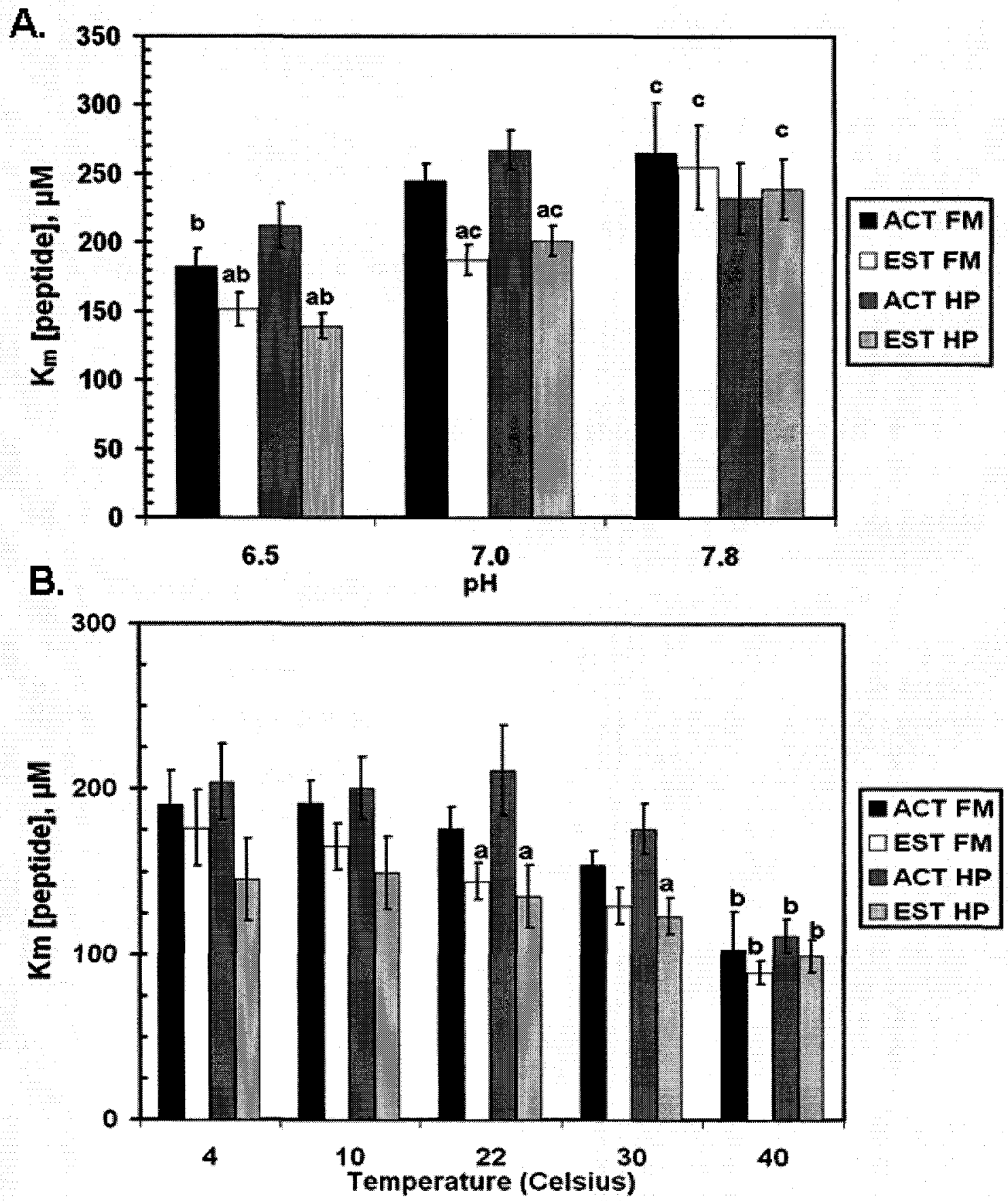


Figure 6.4. O. lactea foot muscle PKG activity as a function of magnesium concentration.

Data are means \pm S.E.M., $n=3$ independent preparations of enzyme assayed at $22^{\circ} \mathrm{C}$ under optimal conditions. 


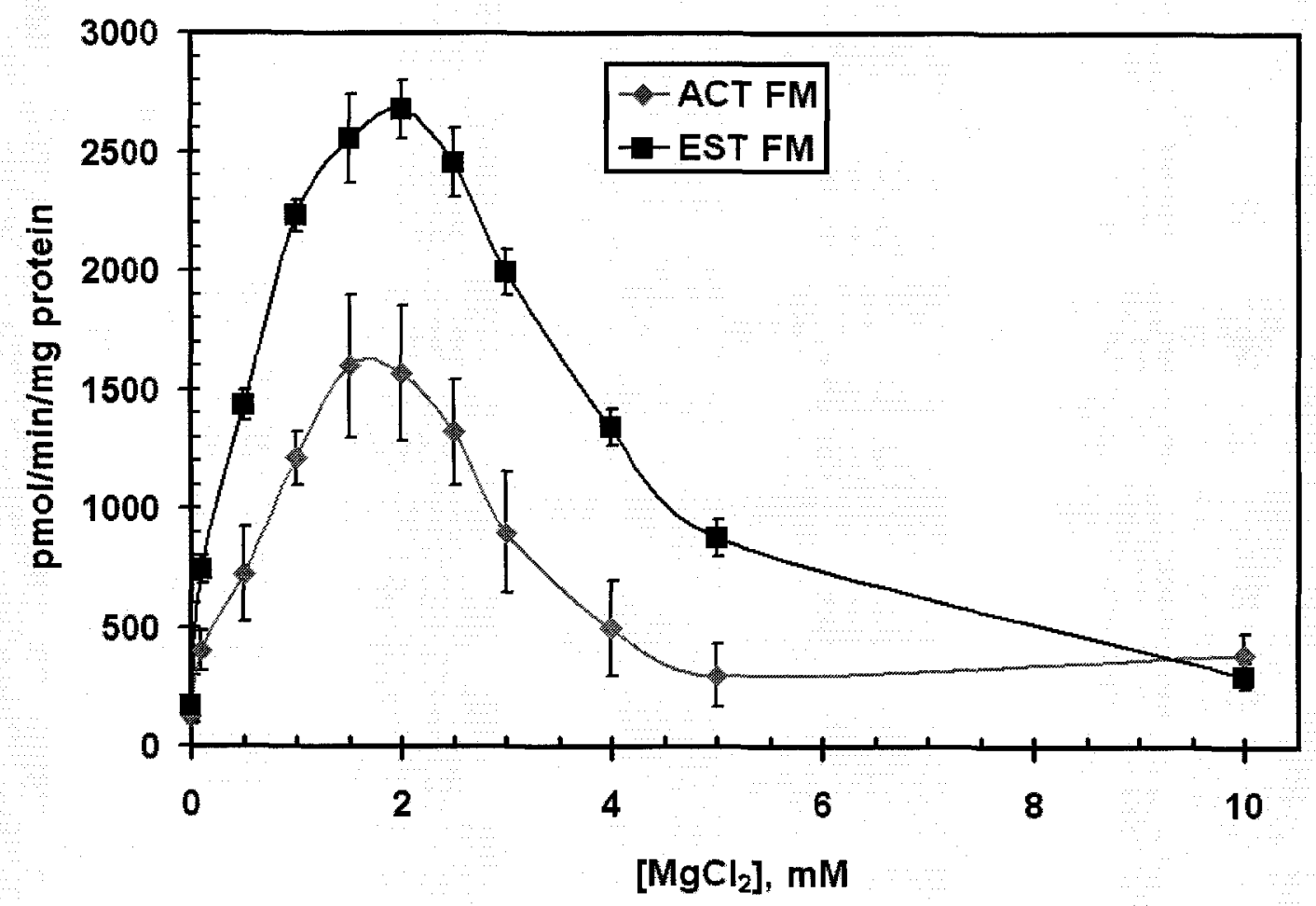


Figure 6.5. Effects of $\mathrm{pH}$ and temperature on the $\mathrm{K}_{\mathrm{m}}$ for SAMS peptide of $O$. lactea foot muscle and hepatopancreas AMPK. (A) Effect of pH. Data are means \pm S.E.M., $n=4$ independent preparations of enzyme assayed at $22^{\circ} \mathrm{C}$. a - Significantly different from the $\mathrm{K}_{\mathrm{m}}$ value for the corresponding AMPK activity in active snails at the same $\mathrm{pH} ; \mathrm{b}$ significantly different from the corresponding $\mathrm{K}_{\mathrm{m}}$ for the same enzyme at all other $\mathrm{pH}$ values. Statistical testing used the Student's t-test, $\mathrm{P}<0.05$. (B) Effect of temperature. Data are means \pm S.E.M., $n=3$ independent preparations. a - Significantly different than the corresponding $\mathrm{K}_{\mathrm{m}}$ value in active snails at same temperature; $\mathrm{b}$ - significantly different than the corresponding $\mathrm{K}_{\mathrm{m}}$ for the same enzyme at all other temperatures assayed, determined by the Student's t-test, $\mathrm{P}<0.05$. 


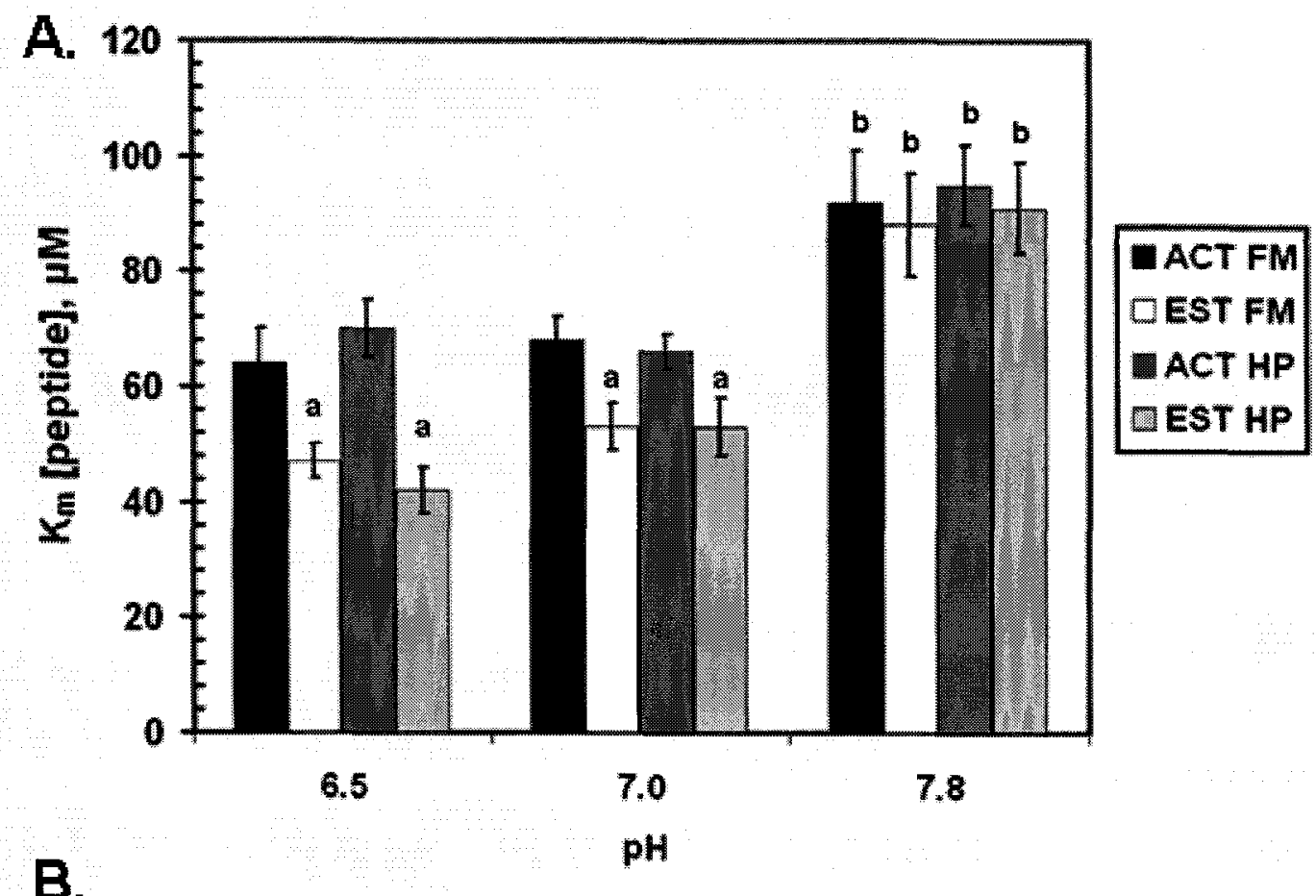

B.

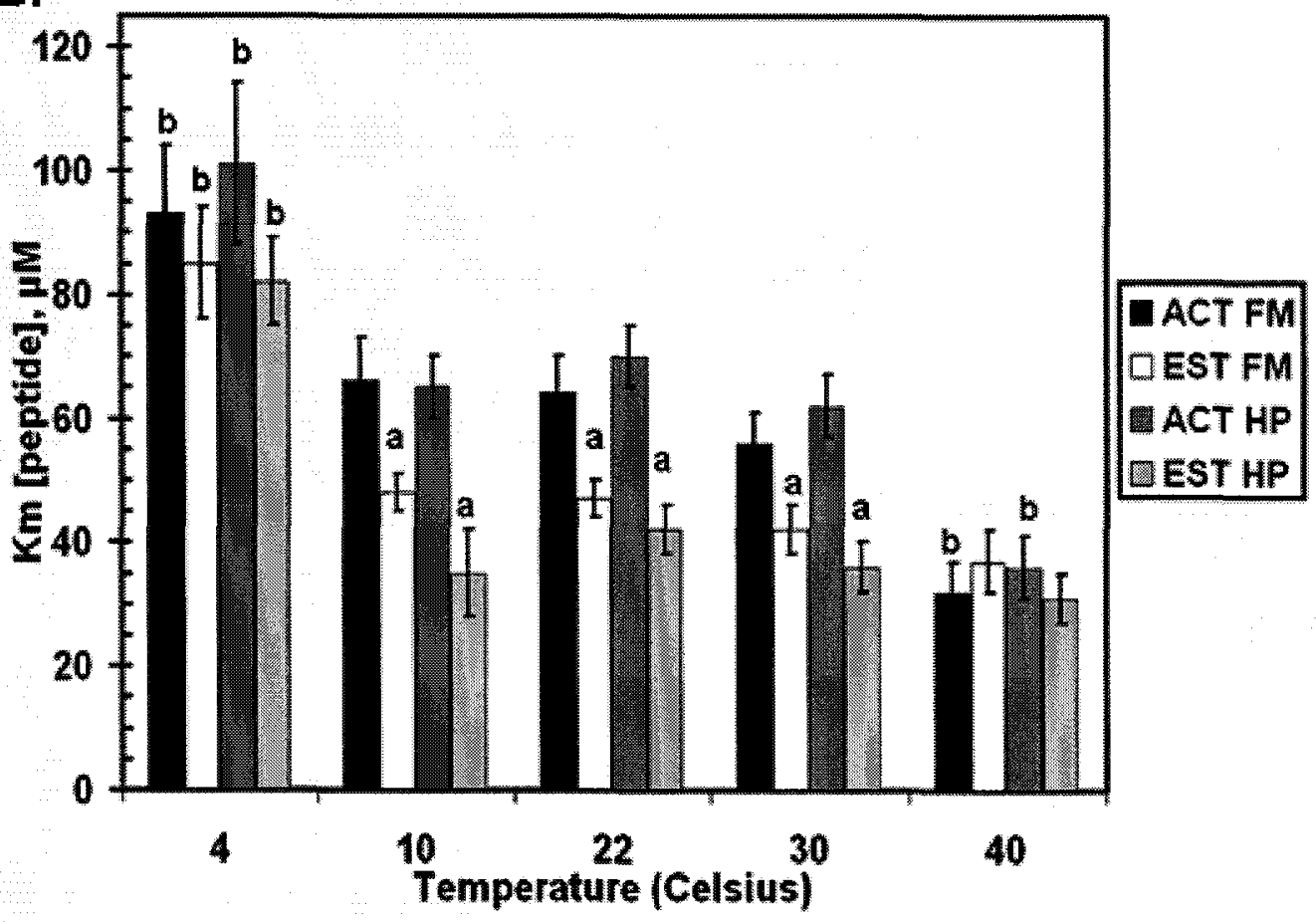


Figure 6.6. Effect of in vitro incubations to stimulate the activities of endogenous (A) protein kinases and (B) protein phosphatases on AMPK in foot muscle extracts from active and estivated $O$. lactea. Incubation time and conditions are described in Materials and Methods and were followed by assay under $\mathrm{V}_{\max }$ conditions at $22^{\circ} \mathrm{C}$. CTR- control incubations with no additions. Data are means \pm S.E.M, $n=4$ independent determinations. a - Significantly different than corresponding active snail value; $b$ significantly different from the corresponding control incubation using the Student's ttest, $\mathrm{P}<0.05$. 


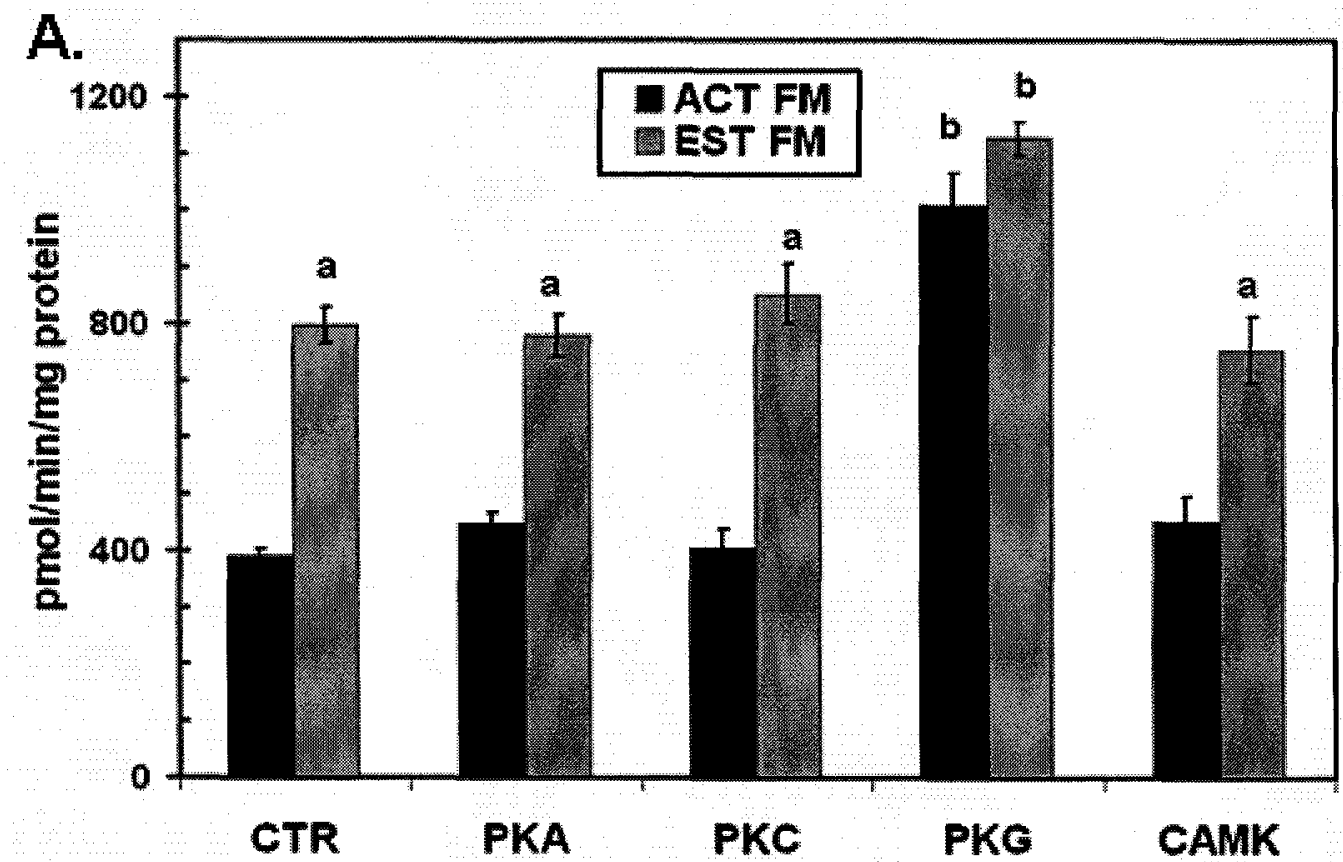

B.

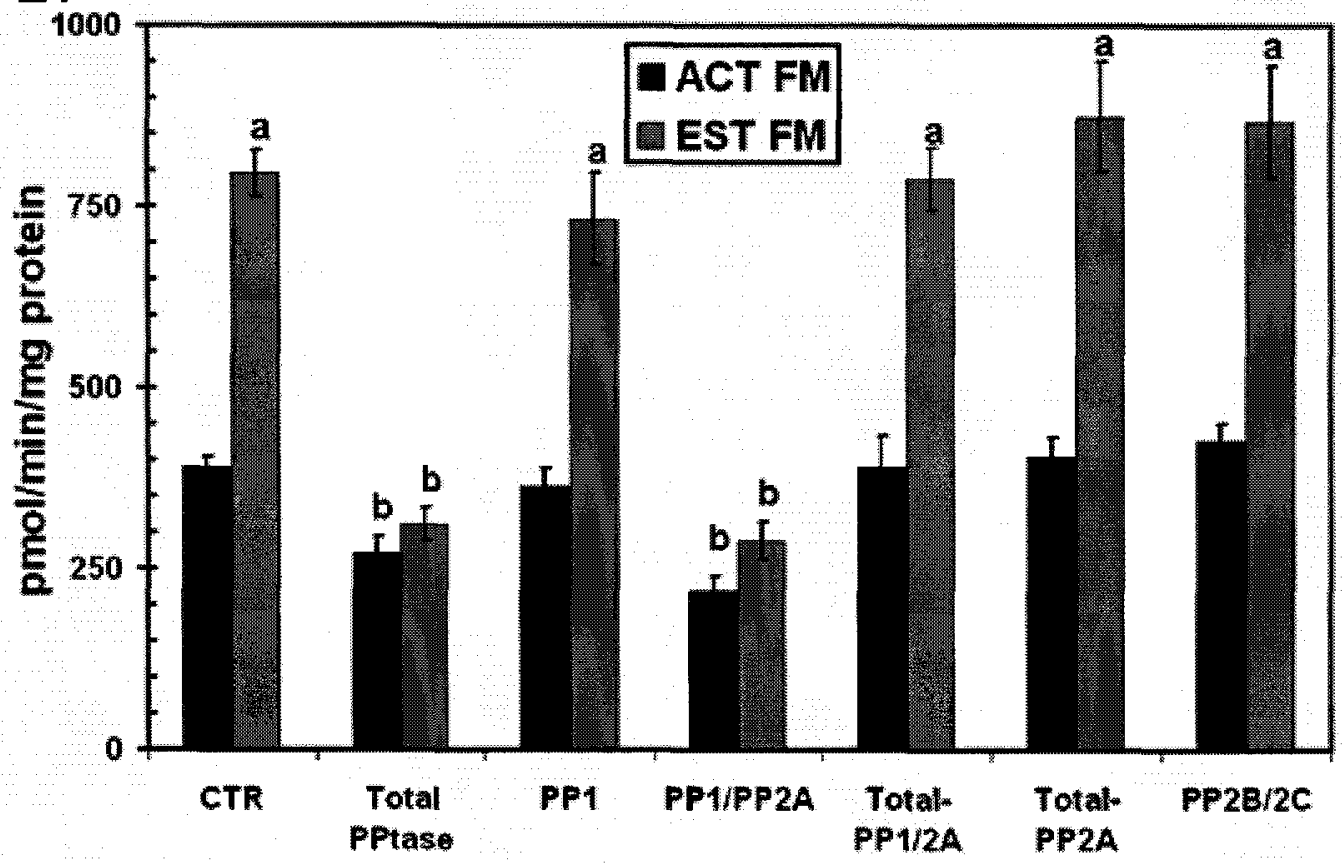


Figure 6.7. Effect of in vitro incubations to assess the effects of stimulating endogenous protein kinases and protein phosphatases on acetyl-CoA carboxylase (A) maximal activity and (B) $\mathrm{K}_{\mathrm{m}}$ ATP in foot muscle extracts from active and estivated $O$. lactea. Incubation time and conditions are described in Materials and Methods and were followed by assay under $\mathrm{V}_{\max }$ conditions at $22^{\circ} \mathrm{C}$. CTR- control incubations with no additions. Data are means \pm S.E.M, $n=4$ independent determinations. a - Significantly different than corresponding active snail value; $b$ - significantly different from the corresponding control incubation using the Student's t-test, $\mathrm{P}<0.05$. 

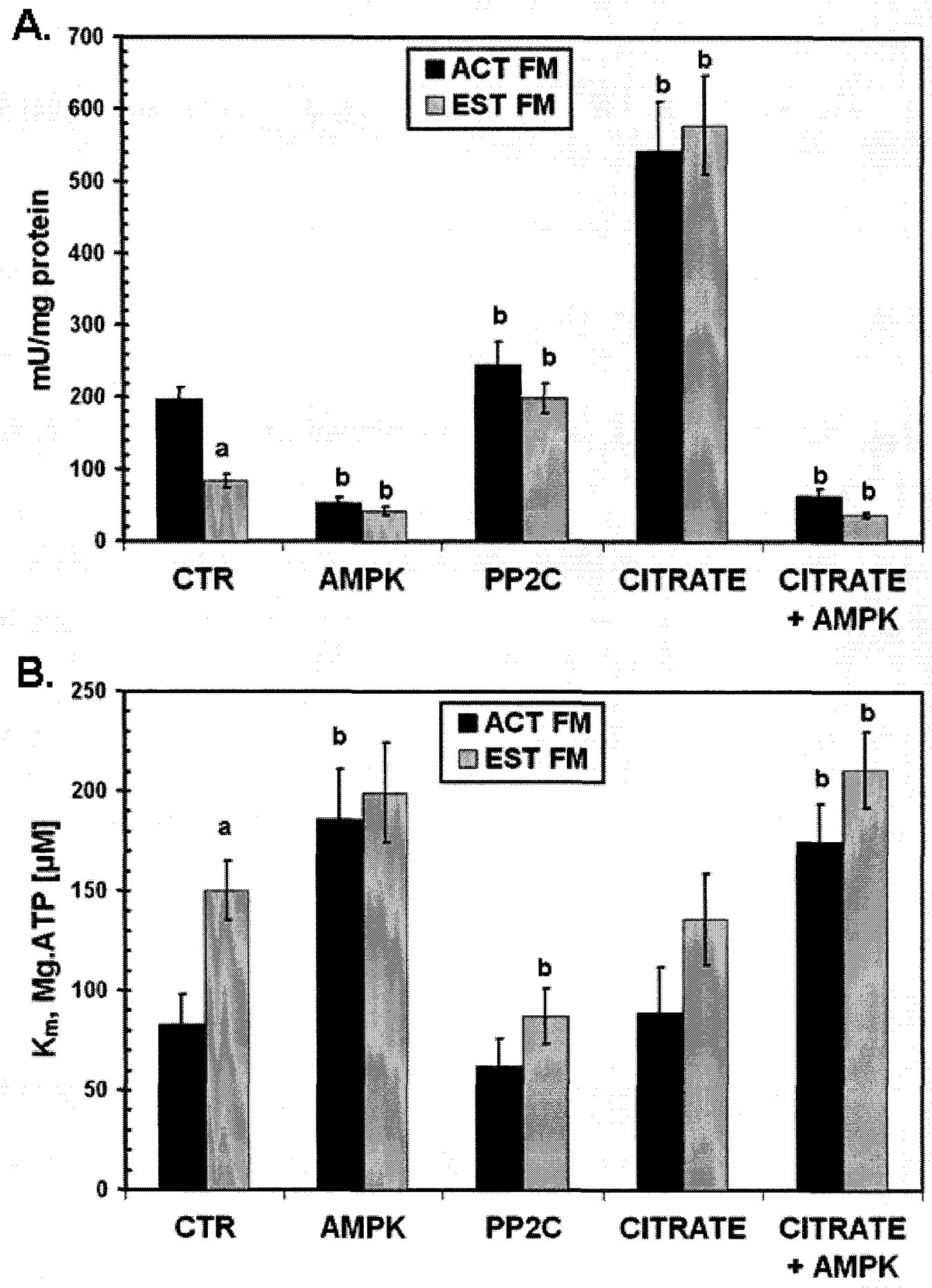
Figure 6.8. Elution profiles for $O$. lactea acetyl-CoA carboxylase activity from foot muscle of active snails off a Sephacryl-S400 gel filtration column. Conditions are: (A) untreated extracts, (B) extracts incubated under conditions that stimulated AMPK, (C) extracts incubated with $20 \mathrm{mM}$ citrate, and (D) extracts incubated with $20 \mathrm{mM}$ citrate in the presence of AMPK stimulation. Activity was measured under optimal $V_{\max }$ conditions at $22^{\circ} \mathrm{C}$. Elution profiles are representative of $n=2$ independent trials. Molecular weight standards are shown as open triangles and are as follows: (1) blue dextran, $2000 \mathrm{kDa}$; (2) thyroglobulin, $670 \mathrm{kDa}$; (3) Jack Bean urease, $545 \mathrm{kDa}$; (4) Bacillus pasteurii urease, 272 $\mathrm{kDa}$; and (5) hemoglobin, $64.5 \mathrm{kDa}$. 

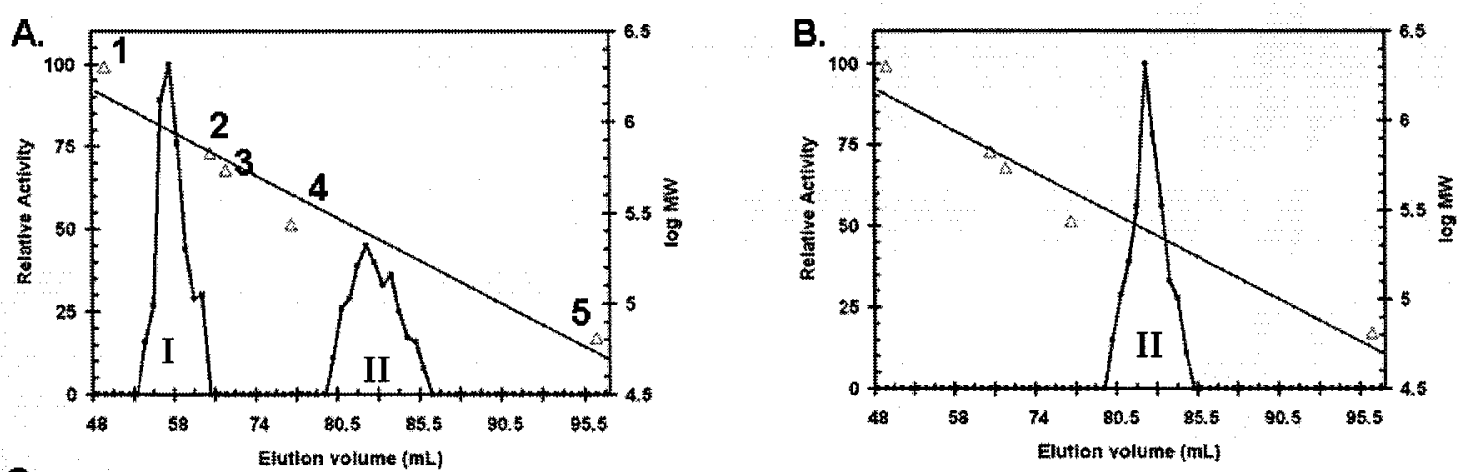

C.
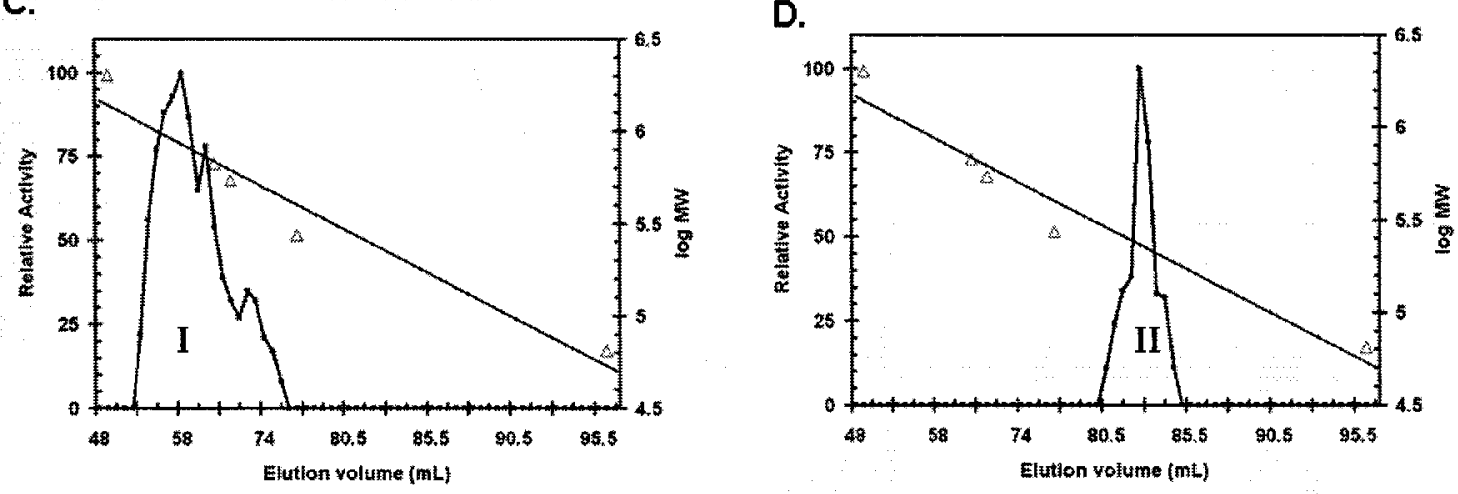
Figure 6.9. Effect of in vitro incubations to stimulate the activities of endogenous (A) protein kinases and (B) protein phosphatases on PKB activity in foot muscle extracts from active and $10 \mathrm{~d}$ estivated $O$. lactea. Incubation time and conditions are described in Materials and Methods followed by assay under $\mathrm{V}_{\max }$ conditions at $22^{\circ} \mathrm{C}$. CTR- control incubations with no additions. Data are means \pm S.E.M, $n=3$ independent determinations. a - Significantly different from corresponding active snail value; $b$ significantly different from the corresponding control incubation using the Student's ttest, $\mathrm{P}<0.05$. 


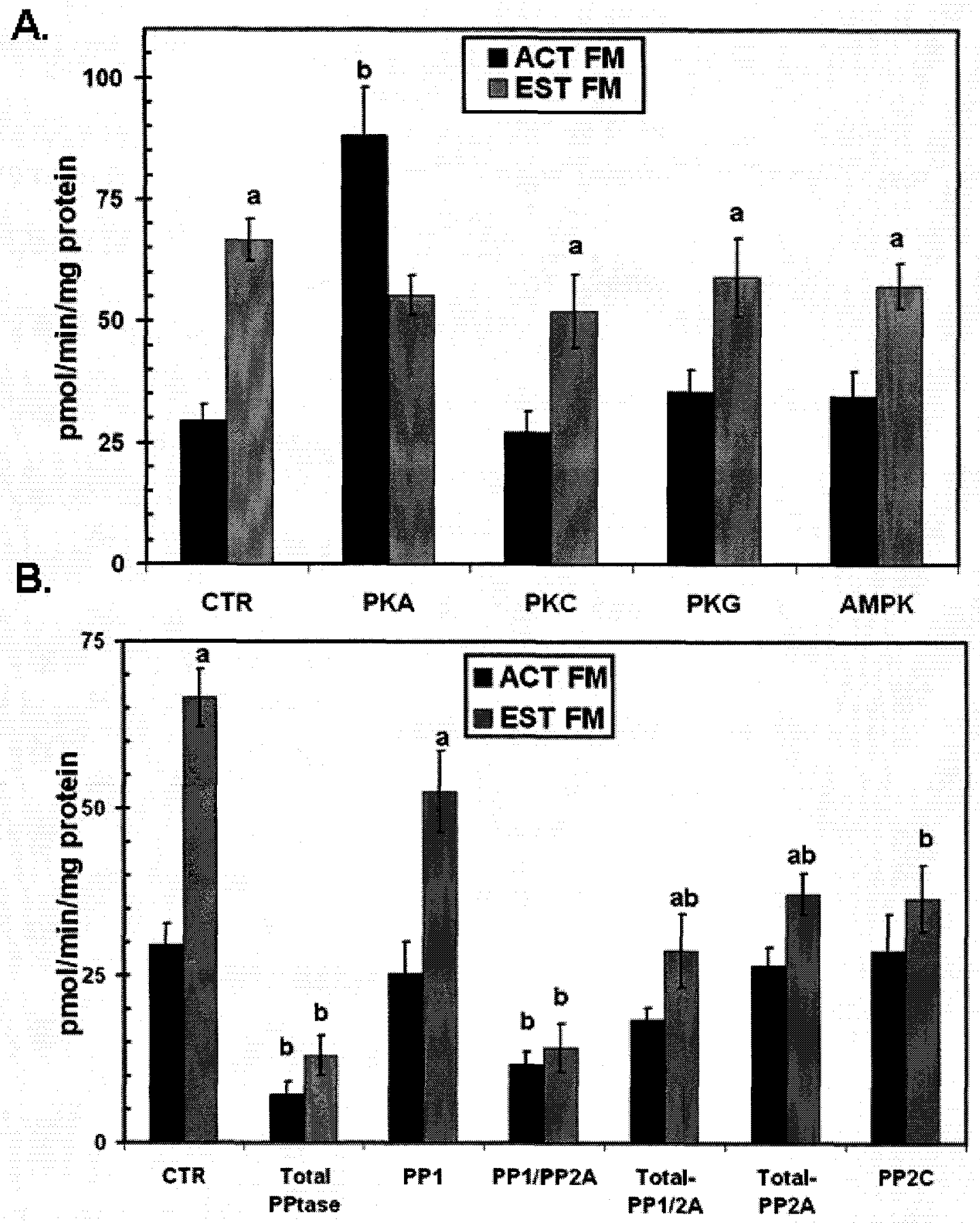


Figure 6.10. Effect of in vitro incubations to stimulate the activities of endogenous (A) protein kinases and (B) protein phosphatases on $\mathrm{PKB}$ activity in hepatopancreas extracts from active and $10 \mathrm{~d}$ estivated $O$. lactea. Incubation time and conditions are described in Materials and Methods followed by assay under $\mathrm{V}_{\max }$ conditions at $22^{\circ} \mathrm{C}$. CTR- control incubations. Data are means \pm S.E.M, $\mathrm{n}=3$ independent determinations. a - Significantly different from corresponding active snail value; $b$ - significantly different from the corresponding control incubation using the Student's t-test, $\mathrm{P}<0.05$. 

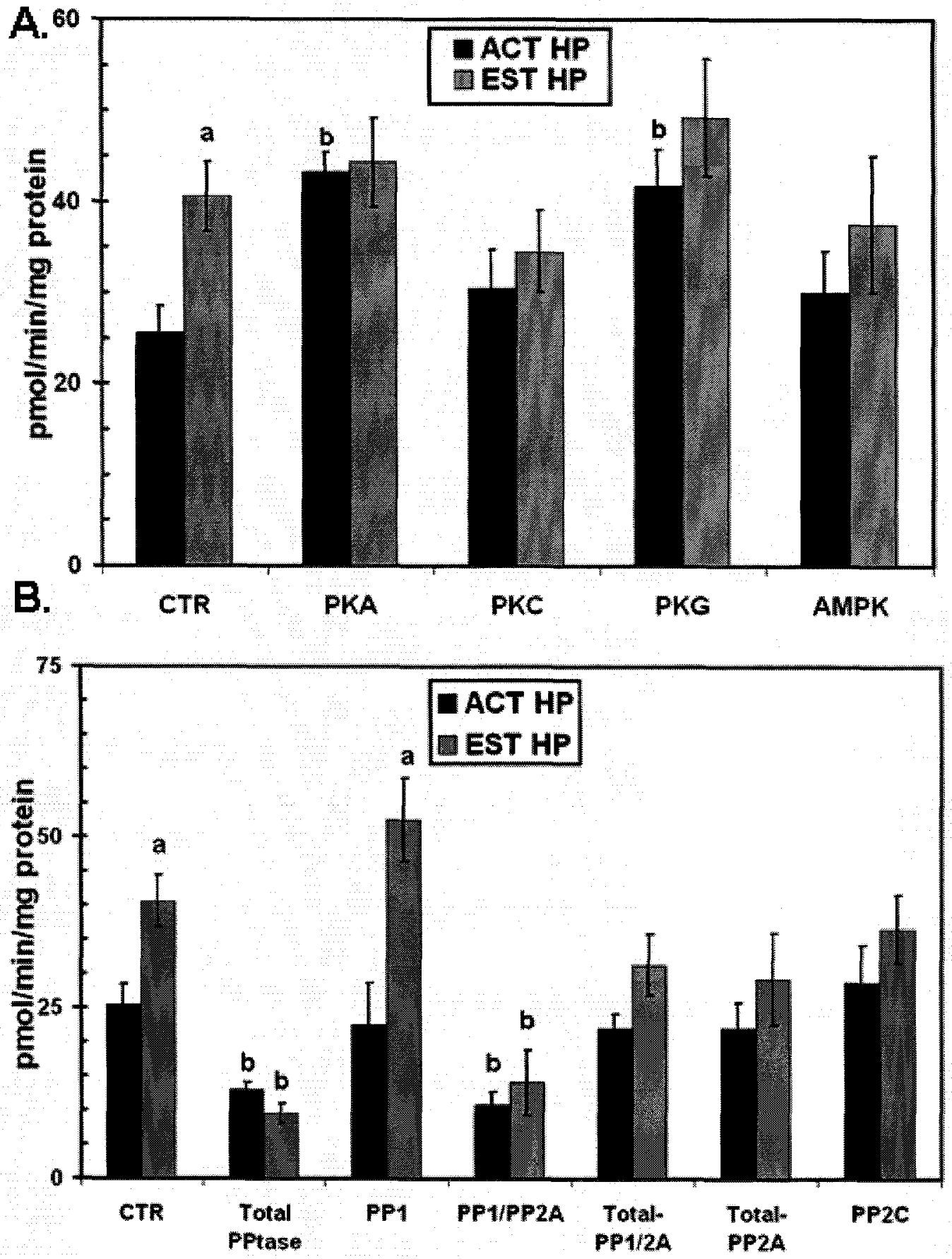
Figure 6.11. Analysis of protein levels of PKB and selected downstream protein targets (FKHRL1, BAD and mTOR) in foot muscle and hepatopancreas of active and estivating O. lactea. (A) Representative Western blots for total proteins and phosphorylated proteins of interest. (B) and (C) Histograms representing relative protein quantities $(\mathrm{n}=3$, \pm S.E.M.) in foot muscle and hepatopancreas, respectively. a - Significantly different from the protein content in the corresponding tissues of active snails using the Student's t-test, $\mathrm{P}<0.05$. 
A.

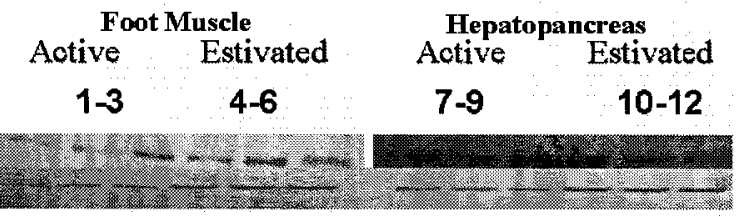

Total FKHRL1

P-Ser256 FKHRL1

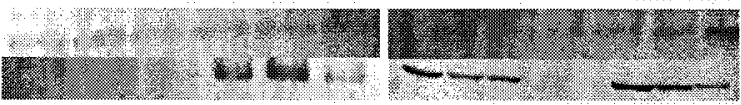

Total BAD

P-Ser136 BAD

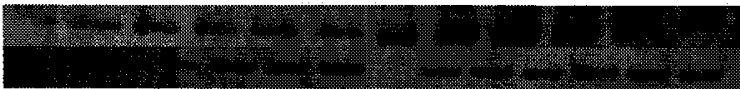

Total mTOR

P-Ser2481 mTOR

P-Ser2448 mTOR

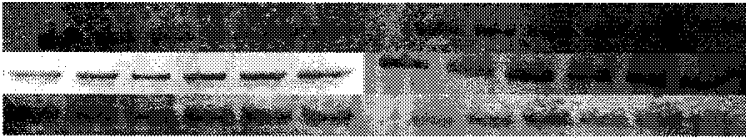

IACT FM $\quad$ EST FM

B.

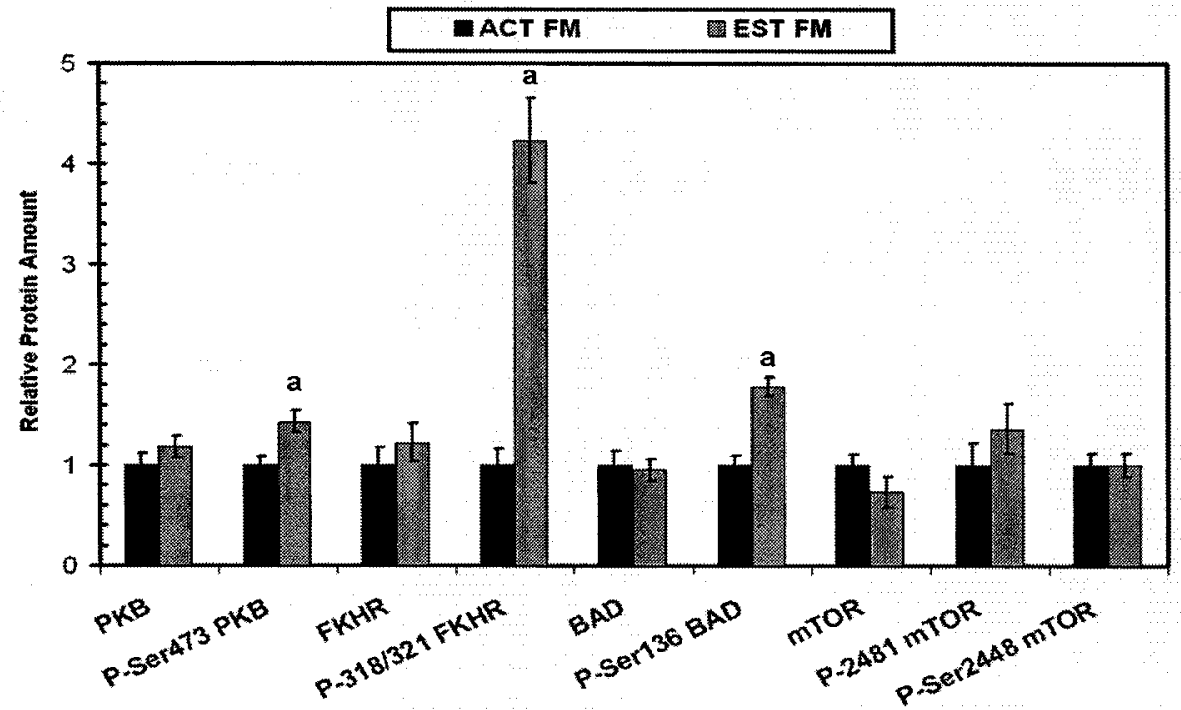

C.

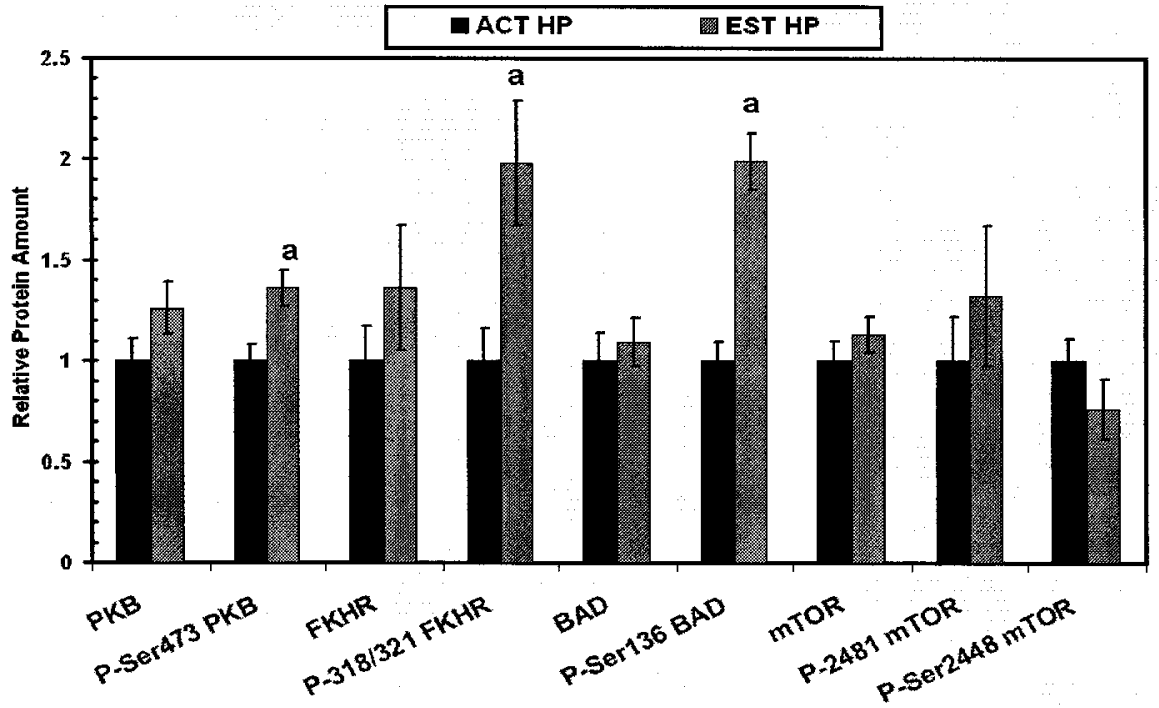


Figure 6.12. Activity of p70S6K in foot muscle and hepatopancreas of active and estivating $O$. lactea. Activities towards the p70S6K-specific peptide substrate KKRNRTLTV (PEP1) and the non-specific substrate RRRLSSLRA (PEP2) are shown. a - Significantly different than the corresponding value for active snails using the Student's t-test, $\mathrm{P}<0.05$. 


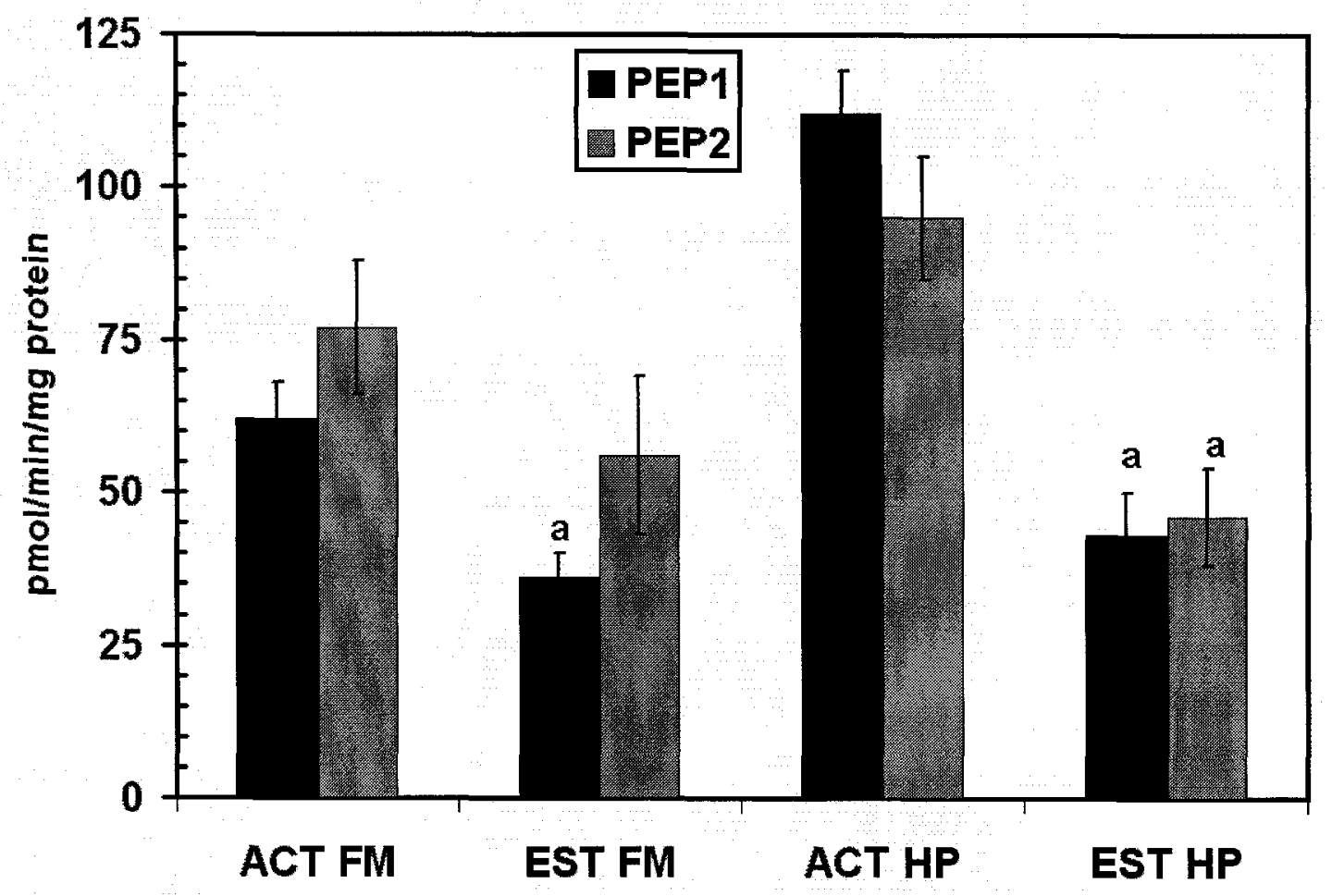




\section{Discussion}

The data in the present chapter suggest an important role for PKG in mediating metabolic responses during estivation in the land snail, $O$. lactea. PKG was the highest activity enzyme of the protein kinases studied and strong, estivation-dependent increases in PKG activity were seen in both foot muscle and hepatopancreas. PKG was assayed with two peptide substrates, Kemptide (a generic substrate representing the phosphopeptide in pyruvate kinase that is a good substrate for PKA and some other kinases) and a PKG-specific peptide, PKISASEFDRPLR. The PKG-specific peptide was synthesized based on bovine lung cGMP-binding cGMP-specific phosphodiesterase, a highly specific substrate for PKG, and the short peptide sequence corresponds to the phosphorylation site targeted by PKG (Colbran et al., 1992). PKG has high affinity, PKC negligible affinity, and PKA relatively weak affinity for this substrate; the phenylalanine (F) appears to confer the difference in PKG and PKA activity towards this peptide (Colbran et al., 1992). Studies with both peptides showed that PKG substrate affinity was markedly enhanced in both tissues during estivation $\left(K_{m}\right.$ values decreased significantly). Hepatopancreas PKG also showed increased substrate affinity for Mg.ATP and increased sensitivity to cGMP activation during estivation whereas the foot muscle enzyme from estivating snails showed increased sensitivity to activation by magnesium and decreased magnesium inhibition. All of these characteristics for both tissues point to a more active form of PKG during estivation. Such stable changes in enzyme properties between two metabolic states are often the result of covalent modification of the protein.

Arrhenius analysis of $\mathrm{PKG}$ activity versus temperature revealed that the activation energy of the enzyme decreased significantly during estivation in both tissues, again 
indicative of a stable modification of the protein and of a more active enzyme.

Temperature studies also revealed that affinity for PKISASEFDRPLR was very stable over a wide range of temperatures from $4^{\circ} \mathrm{C}$ to $30^{\circ} \mathrm{C}$, only increasing at $40^{\circ} \mathrm{C}$. Such stability of enzyme function over a wide temperature range would suit an animal such as $O$. lactea that can encounter wide diurnal and seasonal temperature variations in the arid environments in which it lives. PKG kinetics towards PKISASEFDRPLR were also stable at low $\mathrm{pH}$; the overall $\mathrm{pH}$ optimum for maximal activity was 6.8 and Figure 6.3 shows that substrate affinity was higher at $\mathrm{pH} 6.5$ than at $\mathrm{pH} 7.0$ for PKG in both tissues from estivating snails as well as for active foot muscle PKG. Improved enzyme function at low $\mathrm{pH}$ would also aid PKG function during estivation-hardy adaptation since intracellular $\mathrm{pH}$ drops during dormancy. This is due to respiratory acidosis brought on by irregular ventilation patterns; the pneumostome opens only periodically (to limit desiccation) for a rapid exchange of $\mathrm{O}_{2}$ and $\mathrm{CO}_{2}$ in this and other snail species (Barnhart and McMahon, 1988; Bishop and Brand, 2000).

PKG has diverse functioning across the mollusc phylum. This kinase (and/or the cGMP second messenger that activates it) has been well characterized in the context of neural regulation in such models as Pectin irradians, sea hares of the genus Aplysia, and H. aspersa (Sung et al., 2004; Gomez and Nasi, 2005). There is also substantial evidence linking cGMP/PKG to key regulatory roles in hypometabolism in many mollusc models. An increase in cGMP levels is associated with anoxia exposure in the mussel Mytilus edilus (Holwerda et al., 1981), and cGMP/PKG has been implicated in mediating PK phosphorylation under anoxic conditions in the marine whelk Busycon canaliculatum (Brooks and Storey, 1990), regulating expression of anoxia- and freezing-induced genes 
in Littorina littorea (Larade and Storey, 2004), and regulating several metabolic enzymes in O. lactea (Brooks and Storey, 1997). In previous chapters, PKG was also implicated in the regulation of O. lactea $\mathrm{Na}^{+} \mathrm{K}^{+} \mathrm{ATPase}$ (Chapter 2) and G6PDH (Chapter 3) during estivation. All of these data imply that PKG function would be enhanced under hypometabolic states in mollusc tissues and, indeed, the present analysis of PKG in active versus estivating $O$. lactea confirms this.

The activity of AMPK also increased strongly in both foot muscle and hepatopancreas of estivating $O$. lactea, and like PKG, kinetic characterization of the enzyme was consistent with a more active enzyme in the dormant state. Thus, substrate affinity for SAMS was strongly increased as was sensitivity to AMP activation. AMP can activate AMPK by several mechanisms, including (i) allosteric activation of AMPK by AMP binding, (ii) AMP binding makes AMPK a better substrate for the upstream kinase that phosphorylates (and activates) it, (iii) AMP binding makes AMPK a less effective substrate for protein phosphatases that dephosphorylate (and deactivate) AMPK, and (iv) the upstream kinase is also activated by AMP (Hardie et al., 2000).

Studies of temperature effects revealed a decrease in AMPK activation energy during estivation in hepatopancreas, and the Km SAMS versus temperature profile featured stable substrate affinity between 10 and $30^{\circ} \mathrm{C}$. However, at each temperature studied in that range, the $K_{m}$ SAMS for estivated AMPK was significantly lower than the corresponding value for active snails. Like PKG, substrate affinity for AMPK was also highest at $40^{\circ} \mathrm{C}$ but, unlike PKG, the stability of enzyme affinity did not extend to $4^{\circ} \mathrm{C}$ (where $\mathrm{K}_{\mathrm{m}}$ increased strongly). Affinity for SAMS was very stable at low $\mathrm{pH}$, with no significant differences between $\mathrm{pH} 6.5$ and $\mathrm{pH} 7.0$, but $\mathrm{K}_{\mathrm{m}}$ SAMS increased significantly 
at $\mathrm{pH}$ 7.8. Hence, like PKG, AMPK properties seem to be well designed for function across a broad range of environmental temperatures and at low $\mathrm{pH}$ values such as occur in vivo in the estivating state.

This maximal activity of foot muscle AMPK from both active and estivating $O$. lactea was elevated under incubation conditions that stimulated PKG activity (Figure 6.6). The effect was particularly strong on active extracts where PKG action raised AMPK activity to virtually the same value as in estivated extracts. AMPK is well known to be regulated by its own specific protein kinases (AMPKK), but the present information indicates probable regulatory control by PKG as well. AMPK-mediated phosphorylation inactivates/inhibits the regulatory enzymes of a variety of anabolic pathways and, hence, elevated AMPK activity in estivation could be an integral part of metabolic rate depression, contributing to hypometabolism by turning off various anabolic functions. PKG control over AMPK could bring AMPK-regulated cell functions under the "umbrella" of PKG-mediated actions that coordinate the transition to the hypometabolic state. AMPKK is known to regulate AMPK with respect to changes in cellular energetics (specifically adenylate levels) whereas PKG control could allow the same AMPKregulated cell functions to be suppressed during estivation in the absence of major changes in cellular energetics. Indeed, ATP, ADP and AMP levels were largely unchanged in both foot muscle and hepatopancreas of $O$. lactea when active versus $3 \mathrm{~d}$ estivated snails were compared (Churchill and Storey, 1989).

Incubation studies with foot muscle also showed the O. lactea AMPK was affected by selected protein phosphatase activities and that dephosphorylation reduced AMPK activity back to the level seen in active snails. Deactivation of AMPK was only 
seen when endogenous PP2A activity was stimulated in incubations; the presence of 5 nM okadaic acid, which is sufficient to abolish $100 \%$ of PP2A (refer to Chapter 5), apparently protected AMPK from dephosphorylation and maintained activity at enhanced levels in this tissue.

AMPK activity is dependent on its phosphorylation state in all vertebrate and invertebrate animal systems studied to date (Pan and Hardie, 2002). Phosphorylation of AMPK by an AMPK-specific kinase (AMPKK) activates the enzyme and, while AMP is an allosteric activator of AMPK, phosphorylation of AMPK by AMPKK has an even greater influence on AMPK, increasing activity 50-100 fold (Hardie and Carling, 1997). This study in snail tissues only characterized a modest increase (2.6-fold in active snail foot muscle) in AMPK activity in the presence of cGMP. PKG is not known to phosphorylate AMPK in any system to date, so that particular finding may be unique to this mollusc system. Conversely, there is precedent for AMPK dephosphorylation mediated by protein phosphatase type-2A (Kudo et al., 1996). As well, AMPK phosphorylation state (and activation level) is increased in rat hepatocytes treated with okadaic acid (and other PP1/PP2A inhibitors) in a dose-dependent manner (Samari et al., 2005), further suggesting a role for PP2A in mediating AMPK regulation. Type-2C phosphatases have also been shown to dephosphorylate AMPK (Davies et al., 1995), though this was not observed in the present study.

When AMPK is activated, usually under conditions of cellular energy depletion, AMPK phosphorylates and activates pathways that increase ATP production, while conversely deactivating pathways that consume ATP. One of the prominent downstream targets of AMPK activity is ACC, the rate-limiting step in ATP-consuming fatty acid 
biosynthesis. Though AMPK has many substrates in the cell, the most specific peptide substrate commercially available for AMPK is the SAMS peptide used in this study, which was designed based on a 13-residue sequence around Ser79 on rat ACC. In the design of SAMS, the Ser77 in native rat ACC (the PKA phosphorylation site) was replaced by alanine in the synthetic peptide, abolishing any activity towards SAMS by PKA (Davies et al., 1989) and two arginine residues were added at the C-terminus to increase binding of the peptide to phosphocellulose paper, making it an ideal substrate to use in our assay system.

Since AMPK activity was elevated in estivation, it was not unexpected when this correlated with a strong decrease in ACC activity in both hepatopancreas and foot muscle. Reduced maximal velocity was accompanied by reduced affinity (increased $K_{m}$ ) for Mg.ATP in both tissues, as well as reduced sensitivity to citrate activation in foot muscle. Incubations promoting the phosphorylation of foot muscle ACC implicated AMPK as the only protein kinase tested that was able to reduce ACC activity. AMPK is also known to mediate ACC phosphorylation and deactivation in another invertebrate (Pan and Hardie, 2002). However, incubations promoting PKA had no effect on recoverable ACC activity in active or estivating snails although PKA is known to phosphorylate and deactivate ACC in several rat tissues (Hardie et al., 1986; Winder et al., 1997, Dyck et al., 1999; Munday, 2002). The incubation condition promoting PP2C activity was the only phosphatase-stimulating condition that increased ACC activity or substrate affinity in $O$. lactea foot muscle extracts. Type-2A phosphatases have long been thought to be the main enzyme regulating ACC dephosphorylation (Ingebritsen et al., 1983), but other studies have also pointed to a manganese-dependent phosphatase 
(Mabrouk et al., 1990). Recently a magnesium-dependent phosphatase was characterized in the regulation of ACC in rat pancreatic beta islet cells (Palanivel et al., 2005), a phosphatase which is also activated by glutamate. Little is known about the phosphatase(s) that regulates invertebrate ACC, and this study is the first to suggest that PP2C may be involved.

Mammalian ACC is a dimer but in the presence of citrate, which accumulates when carbon availability is high, the enzyme forms long polymers (upwards of 30 dimers) with high enzymatic activity, stimulating fatty acid biosynthesis (Munday, 2002). Like the mammalian enzyme, $O$. lactea ACC was also activated by citrate with activation constants within the range established for mammals (Munday, 2002); notably, during estivation, foot muscle ACC was less sensitive to citrate activation. Incubations with 20 $\mathrm{mM}$ citrate (approximately $20 \mathrm{X}$ activation constant, and 10X physiological levels) strongly increased ACC activity in extracts of both active and estivating foot muscle, but had no affect on substrate affinity for Mg.ATP. Incubation with citrate failed to increase ACC Vmax when AMPK was stimulated; the results for both $\mathrm{Vmax}$ and $\mathrm{K}_{\mathrm{m}} \mathrm{Mg}$.ATP indicated overriding effects of AMPK in this situation. Thus, it appears that, while citrate can activate $\mathrm{ACC}$ in the estivating land snail (in a manner unrelated to increasing substrate affinity), phosphorylation by AMPK negates citrate activation. Indeed, the data in Figure 6.8 show that AMPK influences the polymerization state of ACC. Gel filtration chromatography showed that both high and low molecular weight forms of ACC existed in $O$. lactea foot muscle. Incubation with citrate shifted all activity into the $1520 \mathrm{kDa}$ form whereas stimulation of AMPK activity converted ACC into the $205 \mathrm{kDa}$ dimer. When AMPK and citrate stimulation were applied together, AMPK effect dominated and 
all activity eluted as the dimer.

PKB activity was elevated during estivation in both foot muscle and hepatopancreas when assayed with the peptide RPRAATF, which is known to be highly selective for $\mathrm{PKB}$ activity in the presence of appropriate inhibitors (and also extremely compatible with P81 phosphocellulose spotting assay) (Bozinovski et al., 2002). PKB was also activated in vitro with incubations that stimulated PKA in both tissues and PKG in hepatopancreas. PKB was deactivated under conditions that stimulated PP2A in both tissues and PP2C in foot muscle. These experiments indicated that activity of PKB in snails, as in other animal systems, is dependent on its phosphorylation state, and suggest that the estivation-related increase in PKB activity may be linked with either PKA or PKG phosphorylation.

The PI3K/PKB signaling cascade is known to regulate and activate a myriad of cellular responses (Brazil et al., 2002). Inactive PKB is localized in the cytosol, and upon $\mathrm{PI} 3 \mathrm{~K}$ activation, $\mathrm{PKB}$ is recruited (via binding to phosphoinositides produced by PI3K) to the plasma membrane and is phosphorylated. Activated PKB is known to phosphorylate and interfere with several pro-apoptotic cell factors such as the transcription factor FKHRL1, which, when phosphorylated, is sequestered in the cytoplasm and is transcriptionally inert (Datta et al., 1999). PKB can also phosphorylate and prevent cell death signaling by the pro-apoptosis protein BAD. Dephosphorylated $\mathrm{BAD}$ is free to move to the mitochondria and interact with apoptosis machinery but, like FKHRL1, BAD is sequestered in the cytoplasm upon PKB-mediated phosphorylation (Brazil et al., 2002). Thus, one context of PKB activation results in pro-survival signaling. Pro-survival signals would be beneficial in estivation where long term viability 
of cells and tissues has to be maintained in a situation where energy expenditures for macromolecular replacement (e.g. new protein synthesis) are greatly suppressed.

PKB also activates cell proliferation and cell growth responses. The enzyme phosphorylates and activates the mTOR Ser/Thr kinase protein. In response to nutrients, growth factors, and insulin, PKB-mediated activation of mTOR leads to translational activation and promotes cell division. The mTOR kinase, in turn, phosphorylates and activates p70S6K. The p70S6K protein has broad substrate specificity and is also activated by a branch of the mitogen activated protein kinase superfamily (MacDonald and Storey, 2005). This Ser/Thr kinase phosphorylates the 40S ribosomal subunit S6 and induces protein translation. However, despite PKB activation in tissues of estivating snails, p70S6K activity was suppressed which suggests an interruption in the normal signal transduction cascade linking these two kinases.

Little previous information is available about PKB responses in animal systems that undergo long term metabolic rate depression. In bats during hibernation, levels of active PKB were decreased in brain, liver, kidney, white adipose tissue, but increased in brown adipose tissue (Eddy and Storey, 2003). In marine snails, L. littorea, under anoxic conditions, PKB and related proteins were unchanged (Larade and Storey, 2006). The pro-survival and apoptosis-limiting signaling that is mediated by PKB activation would benefit the estivating snail; however, the energy expenditures entailed in promoting cell growth, cell division, and protein translation are extremely undesirable during estivation, given the fact that energy reserves are at a premium. Both measurements of PKB activity and immunoblotting to detect the phosphorylated (activated) form of PKB indicated that PKB activity increases during estivation, and analysis of downstream substrates of PKB 
was required to examine the implications of activated PKB in this model estivator.

Immunoblottng analysis showed that, whereas the total protein contents of $\mathrm{PKB}$, FKHRL1, BAD, and mTOR did not change during estivation in either tissue, there were specific increases in amount of phosphorylated FKHRL1 (Ser256) and BAD (Ser136), correlated with the increased abundance of phospho-PKB (Ser473). However, levels of phosphorylated mTOR (both Ser2481 and Ser2448) did not change in estivation and furthermore, the activity of p70S6K decreased in estivation. Hence, during estivation in O. lactea, these two sides of PKB signaling appear to be dissociated. The increase in PKB activity seems to stimulate pro-survival signaling by phosphorylating and inactivating FKHRL1 and BAD, but does not stimulate proliferation/growth signals via mTOR/p70S6K. This makes sense because extension of cell viability is important during estivation but energy limitations in the dormant state restrict macromolecular biosynthesis affecting not just growth/proliferation capacity but also the capacity to replace/turnover damaged cellular components. Antibodies for certain phosphorylation state-specific forms of BAD (Ser112) and FKHRL1 (Ser253, Ser319), as well as antibodies for CREB and NF- $\mathrm{KB}$ total and phosphorylated proteins, failed to cross-react in this species. The absence of signals does not necessarily mean that those proteins were absent in snail tissues; rather, it is more likely that either (i) the proteins were present in low concentrations below the detection limit, (ii) the invertebrate protein was unique enough so that the mammalian antibody failed to bind tightly, or, quite likely, a combination of both factors. Nevertheless, the antibodies that did bind revealed that PKB, BAD, FKHRL1, and mTOR are present in the snail, and molecular weights for these snail proteins are generally consistent with mammalian isoforms as determined by SDS- 
PAGE, and specific phosphorylated forms of PKB, BAD, and FKHRL1 are present in increased amounts in estivating tissues.

In summary, the technique of assaying kinases using P81 phosphocellulose paper arrays combined with phosphor imaging proved successful in determining that PKG, AMPK, and PKB are activated in estivating $O$. lactea. Analysis of downstream kinase targets suggests that only selected branches under AMPK and PKB control are activated in estivating snails. AMPK acts to suppress ACC activity and ATP-consuming fatty acid biosynthesis, while not acting to promote carbohydrate catabolism, a process previously shown to be reduced in dormant $O$. lactea (Brooks and Storey, 1997). Similarly, PKB acts to suppress apoptosis, but PKB activation doesn't result in increased growth and proliferation. Typically, ATP generation is activated by AMPK in concert with suppressing ATP consumption, and cell growth and proliferation is activated by PKB in concert with survival signaling. The selected activation of certain pathways under AMPK and PKB control could be due to the influence of other kinases, particularly PKG, as in vitro incubations stimulating PKG led to the activation of AMPK in foot muscle and PKB in hepatopancreas. PKG or other regulatory elements may influence AMPK or PKB signaling to facilitate the selected activation of desirable branches of AMPK and PKB signaling that facilitate survival during extended dormancy, while simultaneously limiting the pathways that are disagreeable with this animal's needs. 


\section{CHAPTER 7 General Discussion}


Animal species that live in arid environments often use estivation, a state of aerobic dormancy, to allow them to survive for weeks, months or even years under conditions of low water and low food availability that would quickly become lethal for the active animal. Estivation has been characterized in various vertebrate species including lungfish, toads, frogs and some reptiles (Abe, 1995; Withers and Guppy, 1996; Storey, 2004) and occurs widely among invertebrates. In particular, land snails have been well-studied including the model animal examined here, Otala lactea (Brooks and Storey, 1997; Bishop and Brand, 2000; Storey, 2002; Ramos-Vasconcelos and HermesLima, 2003). When food or water is limiting, this pulmonate gastropod enters estivation. Dormancy is characterized by adaptations at behavioural, physiological, and metabolic levels. For example, characteristics of estivation in $O$. lactea include withdrawal of the animal into the shell, production of a calcified mucous membrane (the epiphragm) over the shell opening, reduced and intermittent ventilation, and strong metabolic rate depression.

Metabolic depression serves to greatly extend the time that fixed reserves of endogenous fuels can support survival. Estivating snails typically show metabolic rates that are $<30 \%$ of the corresponding resting rate in active snails (Rees and Hand, 1990; Brooks and Storey, 1997; Bishop and Brand, 2000). The transition into a hypometabolic state requires coordinated suppression of the rates of both ATP-consuming and ATPproducing cell functions as well as a reorganization of the priorities for energy use to sustain key vital functions and suppress the relative activities of many other functions such as growth, development and reproduction (Storey and Storey, 2004). Earlier studies 
of $O$. lactea have, for example, established that the ATP-producing pathways of carbohydrate catabolism are strongly suppressed during estivation, via regulatory controls on rate-limiting enzymes including GP, PFK-1, PK and PDH (Whitwam and Storey, 1990, 1991; Brooks and Storey, 1992, 1997). The primary mechanism implicated in the reversible control of these enzymes was reversible phosphorylation.

Covalent modification of a protein by the addition of a phosphate group (mediated by protein kinases) or its removal (mediated by protein phosphatases) has immediate and typically substantial effects on protein function since phosphate is a negatively charged, hydrophilic, and relatively bulky species whose attachment can readily induce conformation changes in proteins. Protein phosphorylation in animal cells typically targets serine or threonine residues (both have a free hydroxyl group) or tyrosine residues (which feature a phenolic group), and is catalyzed by protein kinase that transfer the high-energy terminal phosphate from ATP onto the target amino acid. The covalent modification is very stable, and removal of phosphate in vivo can only be achieved by corresponding Ser/Thr or Tyr protein phosphatases.

Reversible phosphorylation of cellular proteins is a key regulatory feature of many cellular events, including (i) binding of extracellular factors to membrane receptors (that depend on activation of receptor-mediated kinases and phosphatases to transmit the signal intracellularly); (ii) transduction of signals from the plasma membrane to the nucleus (via several major signal transduction pathways, including the mitogen-activated protein kinase [MAPK] superfamily); (iii) gene expression (activities of transcription factors are often modified by phosphorylation state); (iv) ribosomal assembly and protein synthesis (ribosomal proteins, initiation and elongation factors can be regulated by 
phosphorylation state); and (v) post-translational modifications of proteins, resulting in physiologically relevant changes in protein/enzyme activity states, regulatory properties, and binding associations (Cohen, 1989; Bertorello and Katz, 1995; Hardie and Carling, 1997; Hajduch et al., 2001; Hue et al., 2002; Cowan and Storey, 2003; Alonso et al., 2004; Bozulic et al., 2004; Storey, 2004; Khundmiri et al., 2005).

Given that reversible phosphorylation is one of the most prevalent, encompassing, and influential modes of metabolic regulation, and that reversible phosphorylation has already been established as a regulatory mechanism in decreasing the rate of ATPproducing carbohydrate catabolism in $O$. lactea, the present research aimed to further explore the role of regulatory phosphorylation in other areas of metabolism that could facilitate survival during dormancy. Furthermore, the research explored the roles, properties, and regulation of selected specific protein kinases and phosphatases to identify those that are relevant to the control of estivation.

\section{ATP savings: decreased $\mathrm{Na}^{+} \mathrm{K}^{+}$-ATPase activity regulated by phosphorylation}

In estivation, ATP-consuming cellular functions must be suppressed in a balanced, coordinated fashion in line with the established decrease in ATP-generating processes in order for homeostasis to be re-established in the hypometabolic state. One of the largest consumers of energy in all cells is the membrane ion pump, $\mathrm{Na}^{+} \mathrm{K}^{+}$-ATPase. Maintenance of membrane potential difference is a priority for all cells, even in dormancy, since catastrophic events leading to cell death occur when membrane potential is abolished. In several hypometabolic animal systems, including anoxia-tolerant turtles and estivating frogs, transmembrane sodium and potassium gradients are maintained 
despite much reduced rates of ATP turnover (Buck and Hochachka, 1993; Flanigan et al., 1993). Membrane permeability to $\mathrm{Na}^{+}$and $\mathrm{K}^{+}$is apparently reduced by 'channel arrest' (Hochachka, 1986), and $\mathrm{Na}^{+} \mathrm{K}^{+}$-ATPase activity must be reduced in concert to maintain these vital transmembrane gradients.

The present study of $O$. lactea $\mathrm{Na}^{+} \mathrm{K}^{+}$-ATPase determined that activity is strongly suppressed in tissues during estivation, and in vitro incubations promoting the activity of several protein kinases (PKA, PKC, PKG) were shown to reduce $\mathrm{Na}^{+} \mathrm{K}^{+}$-ATPase activity in extracts of active snails to the levels seen in estivated extracts; conversely, stimulation of specific protein phosphatases (PP1, PP2A) raised the activities measured in tissue extracts from estivated animals back to the levels seen in active snails. Phosphorylation of the sodium pump can be either inhibitory or stimulatory (Cheng et al., 1999) in different systems, depending on factors such as calcium concentration and in $O$. lactea, it was clear that phosphorylation inhibits the enzyme. This would contribute substantially to the overall decrease in ATP consumption in snail tissues that defines estivation.

\section{Phosphorylation implicated in G6PDH activation}

G6PDH was activated in the hepatopancreas from estivating snails, an effect that could possibly facilitate antioxidant defence during dormancy, since estivation and arousal are both associated with oxygen free radical generation (Hermes-Lima et al., 1998). As for $\mathrm{Na}^{+} \mathrm{K}^{+}$-ATPase, in vitro incubations were used to determine which endogenous kinases (PKA, PKG) and phosphatases (PP1, PP2A) influenced G6PDH activity. G6PDH elution profiles from DEAE ion exchange columns showed two peaks of activity in both active and estivated snails, but the proportions of activity in each peak 
changed between active and estivating states (peak I and peak II were predominant in active and estivating snails, respectively). In vitro incubations to stimulate kinase versus phosphatase activities also shifted the peak proportions and confirmed that peak I and II were the low and high phosphate enzyme forms, respectively. These incubations also showed that PKA/PKG stimulation could increase G6PDH activity in active snails to levels comparable to estivated extracts, and that PP1/PP2A stimulation could suppress the high G6PDH activity seen in estivating extracts. Hence, the estivation-dependent rise in G6PDH activity in snail hepatopancreas could be attributed to an increase in the relative amount of G6PDH present as the phosphorylated, higher activity (peak II) enzyme in the dormant state. Interestingly, PKG and PP1 stimulations were each able to fully convert G6PDH into a single peak of activity, documenting full/maximum phosphorylation versus dephosphorylation of the enzyme, respectively.

\section{General suppression of protein phosphatases during estivation}

Since estivation-responsive changes in the activities of key enzymes in $O$. lactea are linked to phosphorylation state, and since overall protein phosphorylation profile changes in estivation (Brooks and Storey, 1995), I proposed that protein phosphatases were differentially regulated in dormancy. Specific phosphatases were implicated in metabolic regulation in $O$. lactea by my earlier work; in particular, both PP1 and PP2A were implicated in the regulation of $\mathrm{Na}^{+} \mathrm{K}^{+}$-ATPase and G6PDH (Chapter 2, 3).

In most studies to date, protein phosphatases have been assayed using

radiolabeled substrates (e.g. ${ }^{32} \mathrm{P}$-labeled glycogen phosphorylase a for PP1 assays). In the research reported in this thesis, however, phosphatases were studied using a 
nonradioactive, ammonium molybdate detection system, and activities were assayed with both short peptide substrates and the generic phosphoprotein casein. Because many phosphatases can dephosphorylate non-specific substrates in vitro, assay conditions were designed to take into account the current state of knowledge regarding the biochemistry of different phosphatases, in order to optimize assay specificity. The traditional phosphatase classification system of phosphatases (PP1 vs. PP2; type-2A vs. type-2B vs. type-2C) can generally be extended to invertebrates, with few exceptions (Cohen, 1989). Thus, assay conditions contained specific ion concentrations, specific inhibitors, and specific activators to distinguish between characteristic phosphatase activities.

Knowledge of phosphatase biochemistry and existing purification protocols in mammals was amalgamated into a scheme to isolate and identify the different $O$. lactea phosphatases. For the most part, snail phosphatases featured kinetic (substrate affinities, ion requirements, etc.) and purification properties that were typical of their designated phosphatase class. The major exception to this was two unusual behaviours of the snail PP2A; the $35 \mathrm{kDa}$ catalytic subunit was unexpectedly retained by the Sepharose-heparin column whereas a substantial portion of PP2A activity remained associated with a protein size of $200 \mathrm{kDa}$, even after trypsin treatment. There are rare precedents for a phosphatase with type-2A activity being retained by heparin (Klumpp et al., 1990, Selke et al.,1998), and for type-2A enzymes with large holoenzyme molecular mass (Cohen, 1989). Large PP2A structures can usually be separated into their composite subunits, including the catalytic subunit, during denaturing SDS-PAGE, which was observed in this study. Little is known about PP2A subunit composition in invertebrates, and SDS-PAGE failed to implicate specific regulatory proteins that could have been part of the $200 \mathrm{kDa}$ complex. 
Nonetheless, the phosphatase purification and identification system used here was largely successful in isolating and characterizing various forms of $O$. lactea protein phosphatases and generally indicated a decrease in activity of PP1 (detailed in Chapter 4) and activities of PP2 enzymes and PTP phosphatases (Chapter 5). The differential regulation of functional type-1 and type-2A phosphatase activities in estivation appeared to be related to differential association into holoenzyme structures with different kinetic characteristics. PTP and type- 2 enzymes also generally featured a change in the relative distribution of activity across subcellular fractions. Decreased phosphatase activity as a whole in estivating snails correlated with the fact that several proteins (Brooks and Storey, 1997), including $\mathrm{Na}^{+} \mathrm{K}^{+}$-ATPase and G6PDH (Chapters 2 and 3), are maintained in highly phosphorylated states in the dormant condition. Combined with the established decrease in PKA activity in estivation (Brooks and Storey, 1996), the reduction in phosphatase activities is indicative of coordinated suppression of the rates of protein phosphorylation and dephosphorylation events, which undoubtedly contributes to the maintenance of the hypometabolic state. However, even though overall reductions in phosphatase activities were observed, physiologically relevant phosphatase activity is targeted to specific substrates in particular subcellular locations by targeting and scaffolding proteins (Cohen, 1989; Cobb and Goldsmith, 1995; Zolnierowicz, 2000; Herzig and Neumann, 2000), and so the full story of protein phosphatase regulation of metabolism during estivation may require further work to evaluate differential phosphatase actions at different subcellular locations. 


\section{Activation of stress-related protein kinases}

While PKA and phosphatase activities are decreased in estivation, other stressrelated kinases might be selectively activated to facilitate survival during extended dormancy. A variety of proteins are maintained in a highly phosphorylated state in estivating $O$. lactea, which indicates that selected kinases muscle remain functional during dormancy. Chapter 6 examined two kinases that are well known to be involved in organismal responses to physiological stress, AMPK and PKB, and a third kinase, PKG, which has been implicated in many contexts in molluscan metabolic regulation, including the regulation of enzymes studied in Chapters 2 and 3. These kinases were assayed using a combination of the traditional P81 paper binding assay with phosphor imaging technology, and although this assay method has not been widely used and has some inherent optimization requirements (discussed in Chapter 6), the technique proved to be highly successful in generating large amounts of data in a reproducible and time-efficient manner.

AMPK responds to a decrease in ATP and an increase in AMP levels, both of which are indicative of energy depletion in the cell, and both of which are relevant to animals that depress metabolic rate for extended periods. AMPK coordinates the deactivation of ATP-consuming processes with the activation of ATP-generating processes to balance ATP supply and demand in cells under different circumstances. In the estivating snail model, the ATP supply and demand equation is somewhat altered since both must be suppressed in concert. Thus, known AMPK actions in inhibiting anabolic functions are seen (e.g. suppressing ACC activity) but opposing actions of AMPK in activating enzymes of ATP-generating catabolism are not (Brooks and Storey, 
1997). The mechanisms that produce this disparate response are undoubtedly key elements in the overall control of metabolic rate depression in animals that exhibit this ability. AMPK activity was markedly increased in snail tissues during estivation, and like $\mathrm{Na}^{+} \mathrm{K}^{+}$-ATPase and G6PDH, incubations that stimulated the actions of protein kinases and phosphatases could influence the activity of AMPK. In particular, stimulation of PKG elevated AMPK activity in extracts from active snails to the levels seen during estivation, whereas incubations that fostered PP2A activity reduced AMPK activity in estivated extracts to the levels seen in active tissues.

A significant downstream substrate of AMPK activity is the enzyme ACC, the rate-limiting step in fatty acid synthesis, which is frequently assayed as a marker of AMPK activity (Horman et al., 2005; Rider et al., 2006). ACC activity was reduced in estivation, and the relative proportion of ACC associated with > $1500 \mathrm{kDa}$ molecular weight was decreased as well. Incubations that stimulated various protein kinases and phosphatases implicated AMPK and PP2C in the primary control of snail ACC. Not only did AMPK stimulation reduce ACC activity, it also blocked the polymerization of ACC dimers into the high molecular weight complex, and overrode the ability of citrate to both activate ACC activity and stimulate the formation of the $>1500 \mathrm{kDa}$ complex. Thus, the estivation-dependent increase in AMPK activity helps to facilitate ATP conservation by suppressing energy-expensive anabolic functions under its control, exemplified here in snail tissues by ACC suppression (Figure 7.1) but also probably applying to other targets of AMPK action such as hydroxymethylglutraryl-CoA (HMG-CoA) reductase and glycogen synthase, the rate-limiting steps in cholesterol and glycogen synthesis, respectively (Hardie and Carling, 1997). 
PKB was also activated in the estivating condition. Activated PKB has many downstream actions, including activating glycogen synthesis, protein synthesis, cell growth and proliferation, and cell survival (Brazil et al., 2002). Many of these functions are not in tune with the needs of the estivating snail since a state of hypometabolism is not conducive to increased rates of biosynthetic processes or cell division. However, one significant "branch" of PKB action that is needed during estivation is its cell survival action. The pro-survival, anti-apoptotic signal actions of PKB could be very important for sustaining long term viability of hypometabolic cells and tissues. Indeed, my studies found that pro-apoptotic mechanisms, mediated by BAD and FKHRL1, were suppressed via $\mathrm{PKB}$-mediated phosphorylation during estivation. Hence, these studies indicated that the increase in PKB activity in estivation correlates with an increase in anti-apoptosis signalling. However, as with AMPK, a disparate response was again seen in that actions of PKB that block apoptosis were seen but actions that are normally oppositely directed to enhance protein synthesis and cell growth/proliferation did not occur. Thus levels of phosphorylated mTOR and p70S6K activity were not increased and in the case of p70S6K, activity was actually decreased in estivation. It remains to be determined how other well-known branches of PKB signalling (e.g. glycogen synthesis) are affected in the estivated condition but it is likely that all anabolic and proliferative functions that are regulated by PKB would be either unaltered or suppressed during estivation (Figure 7.2). Like AMPK, PKB activity was seemingly dependent on phosphorylation state, since incubations stimulating the activity of various phosphatases decreased PKB activity, whereas incubations in the presence of cGMP and Mg.ATP elevated PKB activity, thereby implicating PKG as the kinase that mediates $\mathrm{PKB}$ regulation in this estivating 
model.

Finally, a critical finding of the protein kinase studies was the prominent role of PKG in $O$. lactea estivation. The activity of PKG nearly doubled in foot muscle and hepatopancreas from estivating snails and other studies in this thesis showed that PKG stimulation could mimic many of the estivation-responsive changes in $O$. lactea enzyme activities. Recall that PKG stimulation in vitro mimicked the changes in recoverable $\mathrm{Na}^{+} \mathrm{K}^{+}$-ATPase and G6PDH activities that were observed in vivo in dormant snails and PKG stimulation was also linked with the activation of both AMPK and PKB. PKG has been implicated in regulating several aspects of mollusc biochemistry, from neural regulation to muscle potentiation (Gainey and Greenberg, 2003; Sung et al., 2004; Gomez and Nasi, 2005); in particular, it has been linked with metabolic reorganization during anoxia, another hypometabolic state (Larade and Storey, 2004). Thus, there is precedence for this kinase for having diverse and profound regulatory capacity in mollusc systems. Interestingly, however, in vitro incubations that stimulated the activities of endogenous kinases and phosphatases had no influence on recoverable PKG activity in O. lactea extracts. This suggests to me that PKG may sit at the top of the signal transduction cascade and be responsible for coordinating the responses of a wide variety of downstream signal transduction pathways and metabolic enzymes during estivation.

Clearly, elevated levels of cGMP are implicated and this suggests that an extracellular signal is detected by membrane receptors and transduced into an increase in second messenger levels. In mammalian smooth and skeletal muscle cells, nitric oxide (NO) is known to increase intracellular cGMP levels (by binding and activating soluble guanylate cyclase) with varying physiological ramifications. In conditions such as 
exercise, NO-mediated PKG activation reduces intracellular calcium concentrations through several mechanisms, resulting in vasodilation by relaxing vascular smooth muscle to facilitate oxygen delivery to tissues such as skeletal muscle during oxygen deprivation (Lincoln et al., 1996; Hofmann et al., 2000). NO/cGMP signalling acts to regulate excitation-contraction coupling in skeletal muscle (Stamler and Meissner, 2001), though the exact physiological mechanism of PKG action in this tissue is not clearly defined. The link between NO and cGMP/PKG is applicable to invertebrates, as this signalling pathway has been shown to facilitate survival in D. melanogaster during prolonged hypoxia (Wingrove and O'Farrell, 1999). How PKG is activated during entry into estivation remains to be determined.

\section{Conclusion}

In conclusion, the work presented in this thesis builds on previous studies of the metabolic enzymes of carbohydrate metabolism (reviewed in Brooks and Storey, 1997) to further demonstrate the importance of reversible phosphorylation in metabolic control during estivation in the land snail, $O$. lactea. New contexts of snail metabolism that are regulated by reversible phosphorylation were identified (e.g. ion pumping, pentose phosphate pathway) and defined roles of several protein kinases and protein phosphatases were illustrate, greatly expanding our understanding of the metabolic regulation of estivation. Furthermore, various mechanisms illustrated here for snails may prove to be general principles of metabolic rate depression that are applicable across the animal kingdom. 
Figure 7.1. Schematic of AMP-activated protein kinase (AMPK) signaling in Otala lactea. AMPK is activated when phosphorylated by an upstream kinase (AMPKkinase, or AMPKK) and by allosteric activation by AMP, and deactivated when dephosphorylated by protein phosphatase (in this $O$. lactea study, incubations implicated PP2A). Activated AMPK phosphorylates acetyl-CoA carboxylase (ACC), resulting in a) reduced $\mathrm{ACC}$ activity; b) reduced proportion of $\mathrm{ACC}$ complexed into high activity polymers; and c) reduced ability of citrate to stimulate ACC polymer formation. 


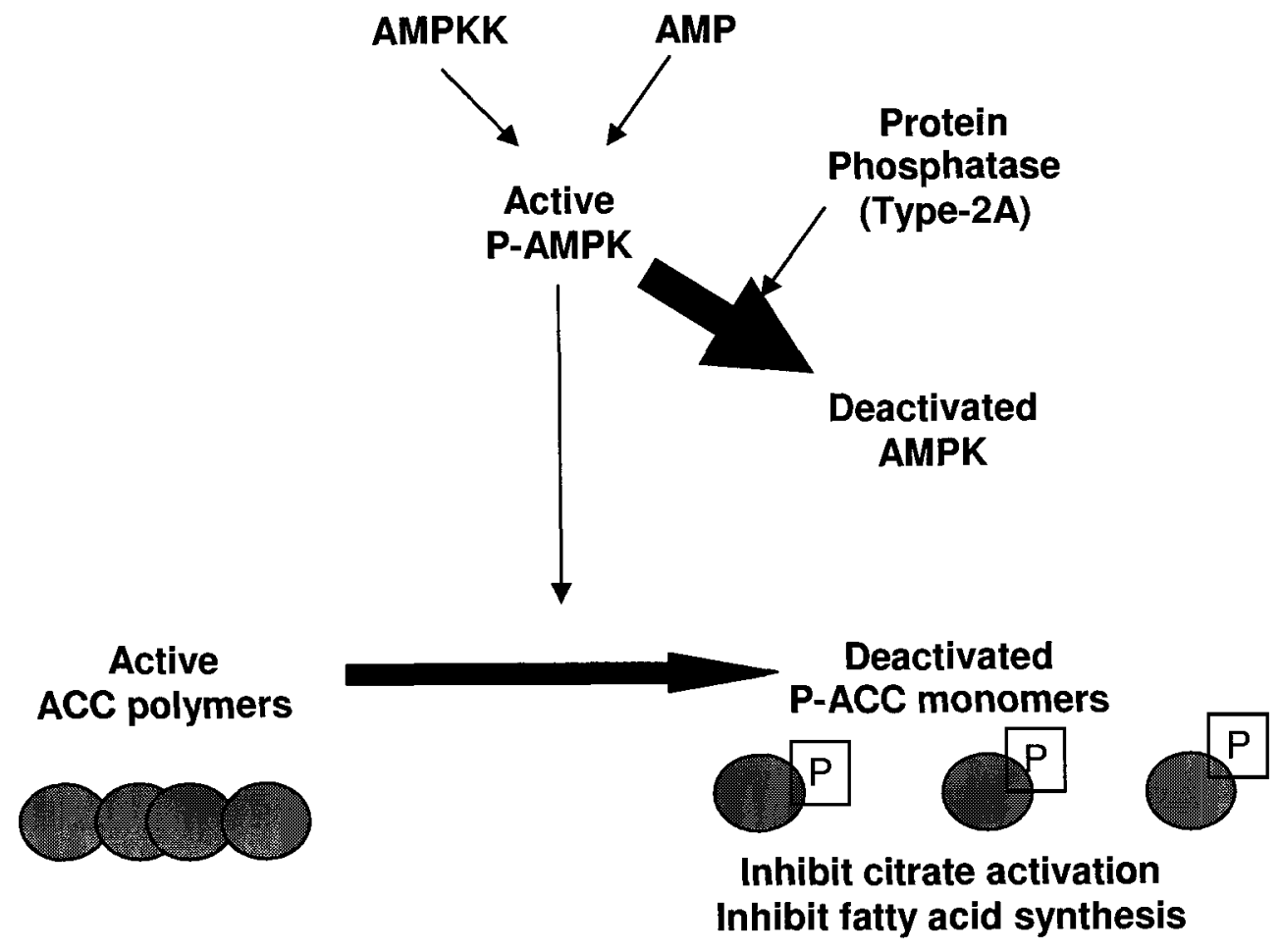


Figure 7.2. Schematic of the PKB signaling pathway. Insulin binds to a membrane receptor (IR), leading to the activation of the phosphoinositide 3 kinase (PI3K). Activated PI3K stimulates the production of 2- or 3-phosphoinositides (IP2 or IP3), which bind and recruit inactive cytosolic $\mathrm{PKB}$ to the cell membrane, where phosphoinositide-dependent kinase (PDK) phosphorylates and activates PKB. Activated PKB mediates several downstream signals, including a) the phosphorylation and inactivation of apoptotis signals BAD and the FKHRL1 transcription factor; $b$ ) the activation of the mTOR (mammalian target of rapomycin) protein, which promotes phosphorylation of $\mathrm{p} 70 \mathrm{~S} 6 \mathrm{~K}$ and leads to protein synthesis; and c) phosphorylation of glycogen synthase kinase (GSK), which prevents GSK from phosphorylating and inhibiting glycogen synthase, faclititating glycogen synthesis. 


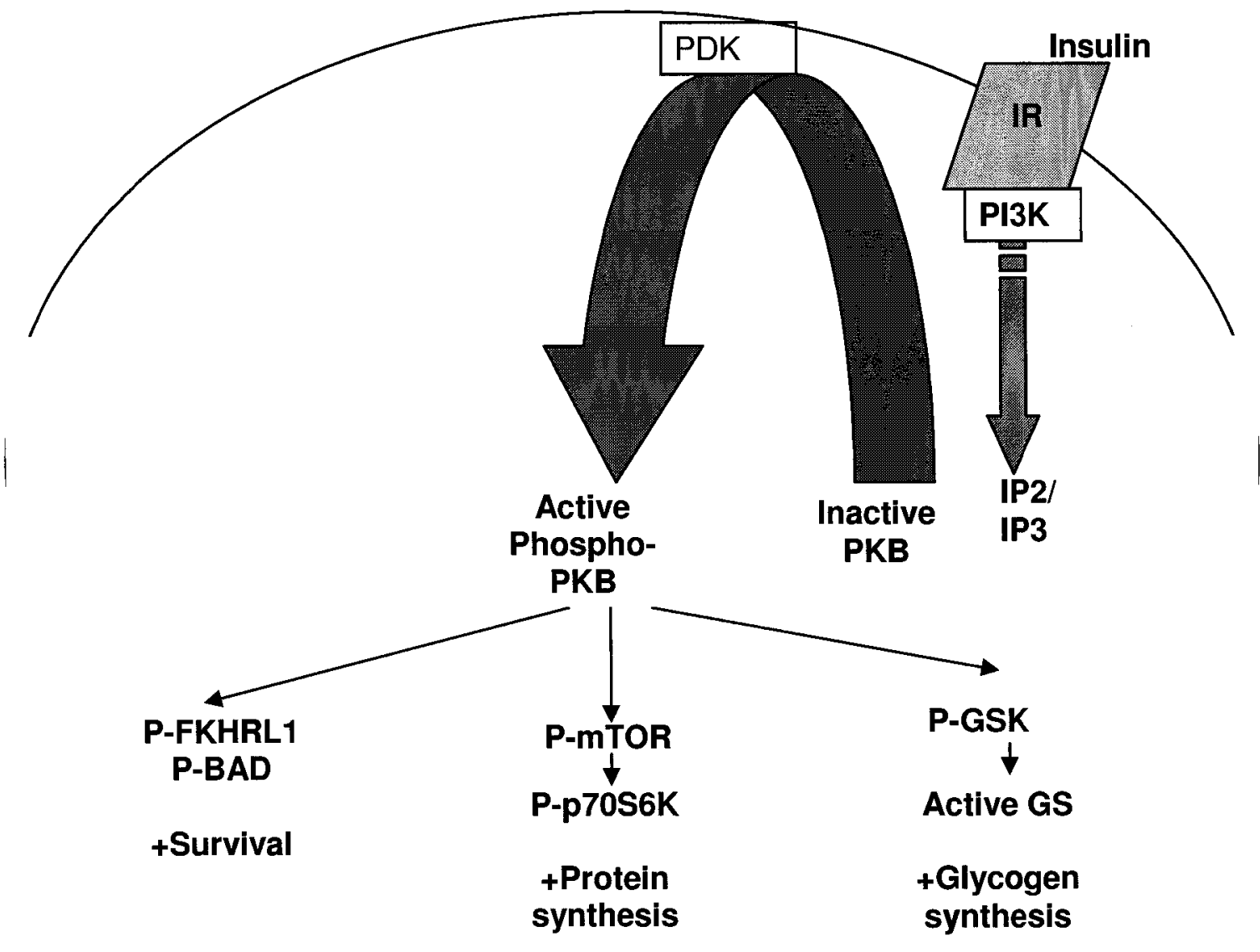




\section{PUBLICATION LIST}

\section{Published Research Articles}

Ramnanan, C.J., and Storey, K.B. (2006). Glucose-6-phosphate dehydrogenase regulation during hypometabolism. Biochem Biophys Res Commun, 339(1): 7-16.

Ramnanan, C.J., and Storey, K.B (2006). Suppression of Na+K+-ATPase activity during estivation in the land snail Otala lactea. J Biol Chem, 209(Pt 4): 677-688.

\section{Research Articles in Preparation}

Ramnanan, C.J., and Storey, K.B. Purification and characterization of type-1 protein phosphatase activity in the estivating invertebrate Otala lactea.

Ramnanan, C.J., and Storey, K.B. The role of type-2 phosphatases in the estivating snail Otala lactea.

Ramnanan, C.J., and Storey, K.B. Profile of protein kinase activity in the estivating snail Otala lactea.

Ramnanan, C.J., and Storey, K.B. The effects of anoxia on sarcoendoplasmic reticulum calcium ATPase (SERCA) activity in the marine periwinkle, Littorina littorea.

Ramnanan, C.J., and Storey, K.B. MAPK profile in the estivating land snail Otala lactea.

\section{Proceedings of Meetings}

Ramnanan, C.J., and Storey, K.B. Regulation of SERCA in estivating Otala lactea by reversible phosphorylation. [Poster] The $46^{\text {th }}$ Annual Meeting of the Canadian Federation of Biological Sciences. Ottawa, June, 2003.

Ramnanan, C.J., and Storey, K.B. Regulation of G6PDH activity by phosphorylation in hepatopancreas of estivating Otala lactea. [Poster] The $6^{\text {th }}$ Annual Chemistry and Biochemistry Graduate Conference (CBGRC). Montreal, November, 2003.

Ramnanan, C.J., and Storey, K.B. Regulation of G6PDH activity by phosphorylation in hepatopancreas of estivating Otala lactea. [Poster] The $10^{\text {th }}$ Annual Bionorth International Life Sciences Conference and Exhibition. Ottawa, November, 2003.

Ramnanan, C.J., and Storey, K.B. G6PDH is activated to enable antioxidant capability in the estivating desert snail Otala lactea. [Poster] Ottawa Carleton Chemistry Institute Poster Day. Ottawa, May, 2004. 
Ramnanan, C.J., and Storey, K.B. [Poster] Regulation of G6PDH activity by phosphorylation in hepatopancreas of estivating Otala lactea. Life in the Cold, $12^{\text {th }}$ International Symposium. Vancouver, BC-Seward, Alaska, July $25^{\text {th }}$-August $1^{\text {st }}, 2004$.

Ramnanan, C.J., and Storey, K.B. Regulation of G6PDH activity by phosphorylation in hepatopancreas of estivating Otala lactea. [Poster] The $3^{\text {rd }}$ International Conference of Comparative Physiology and Biochemistry in Africa: Animals and Environments at the Ithala Game Reserve. KwaZulu-Natal, South Africa, August 7-13 ${ }^{\text {th }}, 2004$.

Ramnanan, C.J., and Storey, K.B. Estivation in the desert snail Otala lactea: Role of Type-2 phosphatases and AMP-activated kinase. [Poster] The $11^{\text {th }}$ Annual Bionorth International Life Sciences Conference and Exhibition. Ottawa, November, 2004.

Ramnanan, C.J., and Storey, K.B. Estivation in the desert snail Otala lactea: Role of Type-2 phosphatases and AMP-activated kinase. [Seminar] 2005 Canadian Society of Zoologists Conference, Kingston, May 10-14 ${ }^{\text {th }}, 2005$. 


\section{REFERENCES}

Abe, A.S. (1995). Estivation in South American amphibians and reptiles. Brazil Journal of Medical and Biological Research, 28:1241-1247.

Adams, J., Chen, Z.P., Van Denderen, B.J., Morton, C.J., Parker, M.W., Witters, L.A., Stapleton, D. and Kemp, B.E. (2004). Intrasteric control of AMPK via the gamma1 subunit AMP allosteric regulatory site. Protein Sci., 13(1):155-65.

Aksoy, Y., Ogus, I.H., and Ozer, N. (2001). Purification and some properties of glucose6-phosphate dehydrogenase. Protein Expression and Purification, 21: 286-292.

Alexanian, A.R., and Bamburg, J.R. (1999). Neuronal survival activity of s100betabeta is enhanced by calcineurin inhibitors and requires activation of NF-kappaB.

FASEB J., (12): 1611-1620.

Alonso, A., Sasin, J., Bottini, N., Friedberg, I., Friedberg, I., Osterman, A., Godzik, A., Hunter, T., Dixon, J., and Mustelin, T. (2004). Protein tyrosine phosphatases in the human genome. Cell, 117(6): 699-711

Asensio, C.J.A. and Garcia, R.C. (2003). Determination of a large number of kinase activities using peptide substrates, P81 phosphocellulose paper arrays, and phosphor imaging. Analytical Biochemistry, 319: 21-33.

Athawale, M.S. and Reddy, S.R. (2002). Storage excretion in the Indian apple snail, Pila globosa (Swainson), during aestivation. Indian Journal of Experimental Biology, 40(11): 1304-1306.

Banerjee, C., Sarkar, D., and Bhaduri, A. (1999). Ca2+ and calmodulin-dependent protein phosphatase from Leishmania donovani. Parasitology., 18 ( Pt 6): 567-573.

Barford, D., Das, A.K. and Egloff, M. (1998). The structure and mechanism of protein phosphatases: insights into catalysis and regulation. Annu. Rev. Biophys. Biomol. Struct. 27: 133-164.

Baril, C. and Therrien, M. (2006). Alphabet, a Ser/Thr phosphatase of the protein phosphatase $2 \mathrm{C}$ family, negatively regulates RAS/MAPK signaling in Drosophila. Dev Biol., 294(1): 232-245

Barnhart, M.C. (1986). Respiratory gas tensions and gas exchange in active and dormant land snails, Otala lactea. Physiological Zoology, 59: 733-745.

Barnhart, M.C., and McMahon, B.R. (1987). Discontinuous carbon dioxide release and metabolic depression in dormant land snails, Journal of Experimental Biology, 128: $123-138$. 
Barnhart, M.C. and McMahon, B.R.. (1988). Depression of aerobic metabolism and intracellular $\mathrm{pH}$ by hypercapnia in land snails, Otala lactea. Journal of Experimental Biology, 138: 289-299.

Beguin, P., Beggah, A.T., Chibalin, A.V., Burgener-Kairuz, P., Jaisser, F., Mathews, P.M., Rossier, B.C., Cotecchia, S. and Geering, K. (1994). Phosphorylation of the $\mathrm{Na}, \mathrm{K}-\mathrm{ATPase}$ alpha-subunit by protein kinase $\mathrm{A}$ and $\mathrm{C}$ in vitro and in intact cells. Identification of a novel motif for PKC-mediated phosphorylation. J. Biol. Chem. 269, 24437-24445.

Bertorello, A.M., Aperia, A., Walaas, S.I., Nairn, A.C. and Greengard, P. (1991).

Phosphorylation of the catalytic subunit of $\mathrm{Na}^{+} \mathrm{K}^{+}$-ATPase inhibits the activity of the enzyme. Proc. Natl. Acad. Sci. USA 88, 11359-11362.

Bertorello, A.M. and Katz, A.I. (1995). Regulation of $\mathrm{Na}^{+}-\mathrm{K}^{+}$pump activity: pathways between receptors and effectors. News Physiol. Sci. 10, 253-259.

Bishop, T. and Brand M.D. (2000). Processes contributing to metabolic depression in hepatopancreas cells from the snail Helix Aspersa. Journal of Experimental Biology, 203: 3603-3612.

Bollen, M. and Stalmans, W. (1988). The modulator protein dissociates the catalytic subunit of hepatic protein phosphatase G from glycogen. Biochem J. 250: 659663.

Boudreau, R.T. and Hoskin, D.W. (2005). The use of okadaic acid to elucidate the intracellular role(s) of protein phosphatase $2 \mathrm{~A}$ : lessons from the mast cell model system.

Int Immunopharmacol. (10): 1507-1518.

Bourdeau, A., Dube, N., and Tremblay, M.L. (2005). Cytoplasmic protein tyrosine phosphatases, regulation and function: the roles of PTP1B and TC-PTP. Curr Opin Cell Biol.17(2): 203-209

Bozinovski, S., Cristiano, B.E., Marmy-Conus, N., and Pearson, R.B. (2002). The synthetic peptide RPRAATF allows specific assay of Akt activity in cell lysates. Anal Biochem. 305(1): 32-39.

Bozulic, L.D., Dean, W.L. and Delamere, N.A. (2004). The influence of protein tyrosine phosphatase-1B on Na,K-ATPase activity in lens. J. Cell Physiol. 200, 370-376.

Brandt, H., Killelea, S.D. and Lee, E.Y. (1974). Activation of phosphorylase phosphatase by a novel procedure: evidence for a regulatory mechanism involving the release of a catalytic subunit from enzyme-inhibitor complex(es) of higher molecular weight. Biochem. Biophys. Res. Comm. 61: 598-604. 
Brandt, H., Lee, E.Y. and Killelea, S.D. (1976). A protein inhibitor of or rabbit liver phosphorylase phosphatase. Biochem. Biophys. Res. Comm. 63: 950-956.

Brazil, D.P, Park, J., and Hemmings, B.A. (2002). PKB binding proteins. Getting in on the Akt. Cell, 111: 293-303.

Breton, S., Beck, J.S., and Laprade, R. (1994). CAMP stimulates proximal convoluted tubule $\mathrm{Na}^{+}, \mathrm{K}^{+}$-ATPase activity. Am. J. Physiol. 266, F400-410.

Brooks, S.P.J. (1992). A simple computer program with statistical tests for the analysis of enzyme kinetics. Biotechniques 13, 906-911.

Brooks, S.P.J. (1994). A program for analyzing enzyme rate data obtained from a microplate reader. Biotechniques 17,1154-1161

Brooks, S.P.J. and Storey, K.B. (1990). CGMP-stimulated protein kinase phosphorylates pyruvate kinase in an anoxia-tolerant marine mollusc. Journal of Comparative Physiology, 160B: 309-316.

Brooks, S.P.J and Storey, K.B. (1992). Properties of pyruvate dehydrogenase from the land snail Otala lactea: control of enzyme activity during estivation. Physiological Zoology, 65(3): 620-633.

Brooks, S.P.J and Storey, K.B. (1994). Metabolic depression in land snails: in vitro analysis of protein kinase involvement in pyruvate kinase control in isolated Otala lactea tissues, J. Exp. Zool. 269: 507-514.

Brooks, S.P.J and Storey, K.B. (1995). Protein phosphorylation patterns during aestivation in the land snail Otala lactea. Molecular and Cellular Biochemistry, 143: 7-13.

Brooks, S.P.J. and Storey, K.B. (1996). Protein kinase involvement in land snail aestivation and anoxia: protein kinase A kinetic properties and changes in second messenger compounds during depressed metabolism. Mol. Cell. Biochem. 156:153-61.

Brooks, S.P.J, and Storey, K.B. (1997). Glycolytic controls in estivation and anoxia: A comparision of metabolic arrest in land and marine molluscs. Comparative Biochemistry and Physiology, 118A(4): 1103-1114.

Bruhat, A., Jousse, C., Carraro, V., Reimold, A.M., Ferrara, M., and Fafournoux, P. (2000). Amino acids control mammalian gene transcription: activating transcription factor 2 is essential for the amino acid responsiveness of the CHOP promoter. Mol Cell Biol. 20(19): 7192-204. 
Buck, L.T., and Hochachka, P.W. (1993). Anoxic suppression of $\mathrm{Na}^{+} \mathrm{K}^{+}$-ATPase and constant membrane potential in hepatocytes: support for channel arrest. American Journal of Physiology, 265: R1010-R1025.

Burns, J.M., Jr., Parsons, M., Rosman, D.E., and Reed, S.G. (1993). Molecular cloning and characterization of a 42-kDa protein phosphatase of Leishmania chagasi. J Biol Chem., 268(23):17155-17161.

Cheng, S. X. J., Aizman, O., Nairn, A. C., Greengard, P., and Aperia, A. (1999). [Ca $\left.{ }^{2+}\right]_{\mathrm{i}}$ determines the effects of protein kinases $A$ and $C$ on activity of rat renal $\mathrm{Na}^{+}, \mathrm{K}^{+}-$ ATPase. J. Physiol. (Lond.) 518, 37-46

Churchill, T.A., and Storey, K.B. (1989). Intermediary energy metabolism during dormancy and anoxia in the land snail Otala lactea, Physiol. Zool. 62: 1015-1030.

Clausen, T. (1986). Regulation of active $\mathrm{Na}^{+} \mathrm{K}^{+}$-ATPase transport in skeletal muscle. Physiology Review, 66: 542-580.

Clausen, T. (2003) $\mathrm{Na}^{+}-\mathrm{K}^{+}$pump regulation and skeletal muscle contractility. Physiol Rev. 83:1269-1324.

Cobb, M.H. and Goldsmith, E.J. (1995). How MAP kinases are regulated. Journal of Biological Chemistry, 270: 14843-14846.

Cohen, P. (1985). The role of protein phosphorylation in the hormonal control of enzyme activity. Eur. J. Biochem. 151: 439-448.

Cohen, P. (1989). The structure and regulation of protein phosphatase. Annual Review of Biochemistry, 58: 453-508.

Cohen, P., Klumpp, S. and Schelling, D.L. (1989). An improved procedure for identifying and quantifying protein phosphatases in mammalian tissues. FEBS Lett. 250: 596-600.

Colbran, J.L., Francis, S.H., Leach, A.B., Thomas, M.K., Jiang, H., McAllister, L.M., and Corbin J.D. (1992). A phenylalanine in peptide substrates provides for selectivity between cGMP- and cAMP-dependent protein kinases. Journal of Biological Chemistry, 267(14): 9589-9594.

Costa Rosa, L.F., Curi, R., Murphy, C., and Newsholme, P. (1995). Effect of adrenaline and phorbol myristate acetate or bacterial lipopolysaccharide on stimulation of pathways of macrophage glucose, glutamine and $\mathrm{O}_{2}$ metabolism. Evidence for cyclic AMP-dependent protein kinase medicated inhibition of glucose-6phosphate dehydrogenase and activation of $\mathrm{NADP}^{+}$-dependent malic enzyme, Biochem. J. 310 (1995) 709-714 
Cowan, K.J., MacDonald, J.A., Storey, J.M, and Storey, K.B. (2000). Metabolic reorganization and signal transduction during estivation in the spadefoot toad. Experimental Biology Online 5, 1.

Cowan, K.J. and Storey, K.B. (2001a). Tyrosine kinases and phosphatases in the estivating spadefoot toad. Cell. Physiol. Biochem., 11:161-172.

Cowan, K.J. and Storey, K.B. (2001b). Protein kinase and phosphatase responses to anoxia in crayfish, Orconectes virilis: purification and characterization of cAMPdependent protein kinase. Comp. Biochem. Physiol. B. Biochem. Mol. Biol. 130: 565-577.

Cowan, K.J. and Storey, K.B. (2002). Urea and KCl have differential effects on enzyme activities in liver and muscle of estivating versus nonestivating species. Biochemistry and Cell Biology, 80(6):745-755.

Cowan, K.J. and Storey, K.B. (2003). Mitogen-activated protein kinases: new signaling pathways functioning in cellular responses to environmental stress. J. Exp. Biol., 206: $1107-1115$.

Crombie, H.J., Bell, M.V. and Tutler, P. (1996). Inhibition of sodium-plus-potassiumstimulated adenosine triphosphatase $\left(\mathrm{Na}^{+} \mathrm{K}^{+}\right.$-ATPase) by protein kinase $\mathrm{C}$ activators in the gills of Atlantic cod (Gadus morhua). Comp. Biochem. Physiol. B 113, $765-772$.

Dagda, R.K., Barwacz, C.A., Cribbs, J.T., and Strack, S. (2005). Unfolding-resistant translocase targeting: a novel mechanism for outer mitochondrial membrane localization exemplified by the Bbeta2 regulatory subunit of protein phosphatase 2A. J. Biol. Chem. 280(29): 27375-27382

da Silva, A.M., Zapella, P.D., Andrioli, L.P., Campanha, R.B., Fiorini, L.C., Etchebehere, L.C., da Costa-Maia, J.C., and Terenzi, H.F. (1999). Searching for the role of protein phosphatases in eukaryotic microorganisms. Braz J Med Biol Res., 32(7): 835-839.

da Silva, A.M., Xavier, G., Leclerc, I., Salt, I.P., Doiron, B., Hardie, G.D., Kahn, A., and Rutter G.A. (2000). Role of AMP-activated protein kinase in regulation by glucose in islet beta cell gene expression. Proceedings of the National Academy of Sciences, 97(8): 4023-4028.

Dagon, Y., Avraham, Y., and Berry, E.M. (2006). AMPK activation regulates apoptosis, adipogenesis, and lipolysis by eIF $2 \alpha$ in adipocytes. Biochemical and Biophysical Research Communications, 340 (1): 43-47 
Das, K.C., and White, C.W. (2002) Redox systems of the cell: possible links and implications, Proc. Natl. Acad. Sci. USA 99: 9617-9618.

Datta, S.R., Brunet, A., and Greenberg, M.E. (1999). Cellular survival: a play in three Akts. Genes and Development, 13: 2905-2927.

Daum, G., Solca, F., Diltz, C.D., Zhao, Z., Cool., D.E., and Fischer, E.H. (1993). A general peptide substrate for protein tyrosine phosphatases. Anal. Biochem. 211: 50-54.

Davies, S.P., Carling, D., and Hardie, D.G. (1989). Tissue distribution of the AMPactivated protein kinase, and lack of activation by cyclic-AMP-dependent protein kinase, studied using a specific and sensitive peptide assay. Eur J Biochem. 186(1-2): 123-128.

Davies, S.P., Sim, A.T.R., and Hardie D.G. (1990). Location and function of three sites phosphorylated on rat acetyl-CoA carboxylase by the AMP-activated protein kinase. European Journal of Biochemistry, 187: 183-190.

Davies, S.P., Helps, N.R., Cohen, P.T., and Hardie, D.G. (1995). 5'-AMP inhibits dephosphorylation, as well as promoting phosphorylation, of the AMP-activated protein kinase. Studies using bacterially expressed human protein phosphatase-2C alpha and native bovine protein phosphatase-2AC. FEBS Lett., 377(3): 421-425.

De Jonge, H.R. (1981). Cyclic GMP-dependent protein kinase in intestinal brushborders. Adv. Cyclic Nucleotide Res., 14: 315-333.

del Pilar Gomez, M. and Nasi, E. (2005). Calcium-independent, cGMP-mediated light adaptation in invertebrate ciliary photoreceptors. J Neurosci. 25(8): 2042-2049.

Delamere, N.A.,Parkerson, J. and Hou, Y. (1997). Indomethacin alters the Na, K-ATPase response to protein kinase $\mathrm{C}$ activation in cultured rabbit nonpigmented ciliary epithelium. Invest. Ophthalmol. Vis. Sci. 38, 866-875

Dickey-Dunkirk, S., Mardaus, M.C. and Killilea, S.D. (1985). Identification and partial characterization of bovine heart cytosolic phosphorylase phosphatases. Arch. Biochem. Biophys. 241: 232-242.

DiGiulio, R.T., Washburn, P.C., Wenning, R.J., Winston, G.W., and Jewell, C.S. (1989). Biochemical responses in aquatic animals: a review of determinants of oxidative stress. Environmental Toxicology and Chemistry, 8: 1103-1123.

Dombradi, V., Gergely, P., Bot., G. and Friedrich, P. (1987). Purification of the catalytic subunit of protein phosphatase-1 from Drosophila melanogaster. Biochem. Biophys. Res. Comm. 144: 1175-1181. 
Donella-Deana, A., Meyer, H.E. and Pinna, L.A. (1991). The use of phosphopeptides to distinguish between protein phosphatase and acid/alkaline phosphatase activities: opposite specificity toward phosphoseryl/phosphothreonyl substrates. Biochim Biophys Acta 1094: 130-133

Donella-Deana, A., Boschetti, M. and Pinna, L.A. (2003). Monitoring of PP2A and PP2C by phosphothreonyl peptide substrates. Methods Enzymol. 366: 3-17.

Dyck, J.R., Kudo, N., Barr, A.J., Davies, S.P., Hardie, D.G., and Lopaschuk, D.G. (1999). Phosphorylation control of cardiac acetyl-CoA carboxylase by cAMPdependent protein kinase and 5'-AMP activated protein kinase. European Journal of Biochemistry, 262(1): 184-190.

Eckman, P. and Jager, O. (1993). Quantification of subnanomolar amounts of phosphate bound to seryl and theronyl residues in phosphoproteins using alkaline hydrolysis and malachite green. Analytical Biochemistry, 214: 138-141.

Enan, E. and Matsumara, F. (1992). Specific inhibition of calcineurin by type II synthetic pyrethroid insecticides. Biochemical Pharmocology, 43: 1777-1784.

Eddy, S.F. and Storey, K.B. (2003). Differential expression of Akt, PPARgamma, and PGC-1 during hibernation in bats. Biochem Cell Biol. 81(4):269-74.

Erdodi, F., Csortos, C., Bot, G. and Gergely, P. (1985). Separation of rabbit liver latent and spontaneously active phosphorylase phosphatases by chromatography on heparin-Sepharose. Biochem. Biophys. Res. Comm. 128: 705-712.

Erdodi, F., Csortos, C., Sparks, L., Muranyi, A. and Gergely, P. (1992). Purification and characterization of three distinct types of protein phosphatase catalytic subunits in bovine platelets. Arch. Biochem. Biophys. 298: 682-687.

Esmann, M. and Skou, J.C. (1988). Temperature-dependencies of various catalytic activities of membrane-bound $\mathrm{Na}^{+} / \mathrm{K}^{+}$-ATPase from ox brain, ox kidney and shark rectal gland and of $\mathrm{C} 12 \mathrm{E} 8$-solubilized shark $\mathrm{Na}^{+} / \mathrm{K}^{+}$-ATPase. Biochim. Biophys. Acta 944, 344-350.

Ewart, H.S., and Klip, A. (1995). Hormonal regulation of the Na+K+-ATPase: Mechanisms underlying rapid and sustained changes in pump activity. American Journal of Physiology, 38: C295-C311.

Fathi, A., Krautheim, A., Lucke, S., Becker, K., and Steinfelder, H.J. (2002). Nonradioactive technique to measure protein phosphatase 2A-like activity and its inhibition by drugs in cell extracts. Analytical Biochemistry, 310: 208-214.

Feschenko, M.S., Stevenson, E., and Sweadner, K.J. (2000). Interaction of Protein Kinase $\mathrm{C}$ and cAMP-dependent Pathways in the Phosphorylation of the Na,K-ATPase. Journal of Biological Chemistry, 275(44): 34693-34700. 
Fischer, E.H., Charbonneau, H., and Tonks, N.K. (1991). Protein tyrosine phosphatases: a diverse family of intracellular and transmembrane enzymes. Science, 253(5018): 401-406.

Fisone, G., Snyder, G.L., Aperia, A. and Greengard, P. (1998). $\mathrm{Na}^{+}, \mathrm{K}^{+}$-ATPase phosphorylation in the choroid plexus: synergistic regulation by serotonin/protein kinase $\mathrm{C}$ and isoproterenol/cAMP-PK/PP-1 pathways. Mol. Med. 4, 258-265.

Flanigan, J.E., Wither, P.C., Fuery, C.J., and Guppy, M. (1993). Metabolic depression and $\mathrm{Na}^{+} / \mathrm{K}^{+}$gradients in the aestivating Australian goldfields frog, Neobatrachus wilsmorei. Journal of Comparative Physiology B, 163: 587-593.

Flockhart, D.A. and Corbin, J.D. (1982). Regulatory mechanisms in the role of protein kinases. CRC Critical Reviews in Biochemistry, 12: 133.

Gainey, L.F. Jr., and Greenberg, M.J. (2003). Nitric oxide mediates seasonal muscle potentiation in clam gills. J Exp Biol. 206(Pt 19):3507-20

Gao, J., Mathias, R.T., Cohen, I.S. and Baldo, G.J. (1992). Isoprenaline, Ca2 ${ }^{+}$, and the Na-K pump in guinea pig ventricular myocytes. J. Physiol. 449, 689-704.

Geering, K. (2001) The functional role of beta subunits in oligomeric P-type ATPases. $J$. Bioenerg. Biomembr. 33: 425-438.

Geering, K., Beguin, P., Garty, H., Karlish, S., Fuzesi, M., Horisberger, J.D., and Crambert, G. (2003) FXYD proteins: new tissue- and isoform-specific regulators of Na,K-ATPase. Ann. N.Y. Acad. Sci. 986: 388-394.

Gergely, P., Erdodi, F. and Bot, G. (1984). Heparin inhibits the activity of protein phosphatase-1. FEBS Lett. 169: 45-48.

Geladopoulos, T.P., Sotiroudis, T.G. and Evangelopoulos, A.E. (1991). Malachite green colorimetric assay for protein phosphatase activity. Anal. Biochem. 192: 112-116.

Gill, G.N., Walton, G.M., and Sperry, P.J. (1977). Guanosine 3':5'-monophosphatedependent protein kinase from bovine lung. Subunit structure and characterization of the purified enzyme. J. Biol. Chem., 252(18): 6443-6449.

Guppy, M., Fuery, C.J., and Flanigan, J.E. (1994). Biochemical principles of metabolic depression. Comparative Biochemistry and Physiology, 109(B): 175-189.

Greenway, S.C. and Storey, K.B. (2000a). Mitogen-activated protein kinases and anoxia tolerance in turtles. Journal of Experimental Zoology, 287: 477-484.

Greenway, S.C. and Storey, K.B. (2000b). Activation of mitogen-activated protein kinases during natural freezing and thawing in the wood frog. Molecular and Cellular Biochemistry, 209: 29-37. 
Grothe, K., Hanke, C., Momayezi, M., Kissmehl, R., Plattner, H., and Schultz, J.E. (1998). Functional characterization and localization of protein phosphatase type 2C from Paramecium. J Biol Chem., 273(30): 19167-19172.

Guppy, M., Fuery, C.J., and Flanigan, J.E. (1994). Biochemical principles of metabolic depression. Comparative Biochemistry and Physiology B, 109: 175-189.

Gupta, R.C., Khandelwal, R.L., and Sulakhe, P.V. (1990). Effects of sulfhydryl agents, trifluoperazine, phosphatase inhibitors and tryptic proteolysis on calcineurin isolated from bovine cerebral cortex. Mol. Cell. Biochem. 97(1): 43-52.

Guseva, N.V., Taghiyev, A., Sturm, M.T., Rokhlin, O. W., and Cohen, M.B. (2004). Tumor necrosis factor-related apoptosis-inducing ligand-mediated activation of mitochondria-associated nuclear factor-kappaB in prostatic carcinoma cell lines. Mol Cancer Res. 2(10): 574-584

Hajduch, E., Litherland, G.J., and Hundal, H.S. (2001). Protein kinase B( PKB/Akt) - a key regulator in glucose transport? Federation of European Biochemical Societies, 492:199-203.

Hardie, D.G., Carling, D., Ferrari, S., Guy, P.S., and Aitken, A. (1986). Characterization of the phosphorylation of rat mammary ATP-citrate lysase an acetyl-CoA carboxylase by $\mathrm{Ca}^{2+}$ and calmodulin-dependent mutliprotein kinase and $\mathrm{Ca}^{2+}$ and phospholipid-dependent protein kinase. European Journal of Biochemistry, 157: 553-561.

Hardie, D.G. and Carling, D. (1997). The AMP-activated protein kinase: Fuel gauge of the mammalian cell? European Journal of Biochemistry, 246: 259-273.

Hardie, D.G., Salt, I.P., and Davies, S.P. (2000). Analysis of the role of the AMPactivated protein kinase in the response to cellular stress. Methods Mol Biol. 99: 63-74

Hardie, D.G.., and Pan, D.A. (2002). Regulation of fatty acid synthesis and oxidation by the AMP-activated protein kinase. Biochemical Society Transactions, 30: 10641070 .

Hayakawa, Y. and Chino, H. (1985). Insect fat body phosphorylase kinase is $\mathrm{Ca}^{2+}$ independent and acts even at $0^{\circ} \mathrm{C}$. Biochim. Biophys. Acta. 746:14-17

Hellstern, S., Dammann, H., Husain, Q., and Mutzel, R. (1997). Overexpression, purification, and characterization of Dictyostelium calcineurin A. Res. Microbiol., 14: $335-343$.

Hermes-Lima, M., and Storey, K.B. (1995). Antioxidant defenses and metabolic depression in a pulmonate land snail, Am. J. Physiol., 268: R1386-R1393

Hermes-Lima, M., Storey, J.M., and Storey K.B. (1998). Antioxidant defenses and metabolic depression. The hypothesis of preparation for oxidative stress in land snails. Comparative Biochemistry and Physiology, 120(B): 437-448. 
Herreid, C.F. (1977). Metabolism of land snails (Otala lactea) during dormancy, arousal and activity. Comparative Biochemistry and Physiology, 56(A): 211-215

Herzig, S. and Neumann, J. (2000). Effects of serine/threonine protein phosphatases on ion channels in excitable membranes. Physiol. Rev. 80: 173-210.

Higgins, W.J. and Greenberg, M.J. (1974). Intracellular actions of 5-hydroxytrypatmine on the bivalve myocardium-II. Cyclic nucleotide-dependent protein kinase and microsomal calcium uptake. Journal of Experimental Zoology, 190: 305-316.

Higuchi, E., Nishi, A., Higashi, H., Ito, Y. and Kato, H. (2000). Phosphorylation of protein phosphatase-1 inhibitors, inhibitor-1 and DARPP-32, in renal medulla. Eur. J. Pharmocol. 408, 107-116.

Hochachka, P.W. (1986). Defence strategies against hypoxia and hypothermia. Science 231, 234-241.

Hochachka, P.W., Buck, L.T., Doll, C.J. and Land, S.C. (1996). Unifying theory of hypoxia tolerance: molecular/metabolic defense and rescue mechanisms for surviving oxygen lack. Proc. Natl. Acad. Sci. USA 93, 9493-9498.

Hofmann, F., Ammendola, A., and Schlossmann, J. (2000). Rising behind NO: cGMPdependent protein kinases. J. Cell Science, 113: 1671-1676.

Holwerda, D.A., Druitwagen, E.C.J, and de Bont, A.M. (1981). The regulation of pyruvate kinase and phosphoenolpyruvate carboxykinase activity during anaerobiosis in Mytilus edulis L. Molecular Physiology, 1: 165-171.

Horman, S., Hussain, N., Dilworth, S.M., Storey, K.B., and Rider, M.H. (2005). Evaluation of the role of AMP-activated protein kinase and its downstream targets in mammalian hibernation. Comp. Biochem. Physiol., 142(B): 374-382.

Hotamisligil, G.S. (2003). Inflammatory pathways and insulin action. Int J Obes Relat Metab Disord., 27(3): S53-55.

Hubbard, M.J., and Cohen, P. (1993). On target with new mechanism for the regulation of protein phosphorylation. Trends in Biochemical Sciences, 18: 172-177.

Hue, L., Beauloye, C., Bertrand, L., Hormon, S., Krause, U., Marsin, A-S., Meisse, D.,Vertommen, D. and Rider M.H. (2002). New targets of AMP-activated protein kinase. Biochemical Society Transactions, 31(1): 213-215. 
Humphrey, P.A., Lupfert, C., Apell, H.J., Cornelius, F. and Clarke, R.J. (2002). Mechanism of the rate-determining step of the $\mathrm{Na}^{+}, \mathrm{K}^{+}$-ATPase pump cycle. Biochemistry 41, 9496-9507.

Ingebritsen, T.S., Stewart, A.A., and Cohen, P. (1983). The protein phosphatases involved in cellular regulation. Measurement of type- 1 and type- 2 protein phosphatases in extracts of mammalian tissues; an assessment of their physiological roles. Eur J Biochem. 132(2): 297-307.

Inoue, K., Sohma, H., and Morita, F. (1990). Ca2(+)-dependent protein phosphatase which dephosphorylates regulatory light chain-a in scallop smooth muscle myosin. J Biochem., 107(6): 872-978.

Jones, R.M. (1980). Metabolic consequences of accelerated urea synthesis during seasonal dormancy of spadefoot toads, Scaphiopus couchii and Scaphioipus multiplicatus. Journal of Experimental Zoology, 212: 255-267.

Kamibayashi, C., Estes, R., Slaughter, C. and Mumby, M.C. (1991). Subunit interactions control protein phosphatase 2A. J. Biol. Chem. 266: 13251-13260.

Khundmiri, S.J., Dean, W.L., McLeish, K.R., and Lederer, E.D. (2005). Parathyroid hormone-mediated regulation of $\mathrm{Na}^{+} \mathrm{K}^{+}$-ATPase requires ERK-dependent translocation of protein kinase Ca. J. Biol. Chem. 280, 8705-8713.

Kimuri, K., Spate, L.D., Green, M.P., and Roberts, R.M. (2004). Effects of oxidative stress and inhibitors of the pentose phosphate pathway on sexually dimorphic production of IFN-tau by bovine blastocysts, Mol. Reprod. Devel. 68: 88-95.

Kiroytcheva, M., Cheval, L., Carranza, M. L., Martin, P.-Y., Favre, H., Doucet, A., and Feraille, E. (1999). Effect of cAMP on the activity and the phosphorylation of $\mathrm{Na}^{+}, \mathrm{K}^{+}$-ATPase in rat thick ascending limb of Henle. Kidney Int. 55, 1819-1831.

Kissmehl, R., Treptau, T., Kottwitz, B., and Plattner, H. (1997). Occurrence of a paranitrophenyl phosphate-phosphatase with calcineurin-like characteristics in Paramecium tetraurelia. Arch Biochem Biophys., 344(2): 260-270.

Kloeker, S., Reed, R., McConnell, J.L., Chang, D., Tran, K., Westphal., R.S., Law, B.K., Colbran, R.J., Kamoun, M., Campbell, K.S., and Wadzinski, B.E. (2003). Parallel purification of three catalytic subunits of the protein serine/threonine phosphatase 2A family (PP2A(C), PP4(C), and PP6(C)) and analysis of the interaction of PP2A(C) with alpha4 protein. Protein Expr. Purif., 31(1):19-33.

Klumpp, S., Cohen, P. and Schultz, J.E. (1990). Chromatographic separation of four Ser/Thr-protein phosphatases from solubilized ciliary membranes of Paramecium tetraurelia by heparin-sepharose. J. Chromatogr. 521: 179-186. 
Klumpp, S., Hanke, C., Donella-Deana, A., Beyer, A., Pinna, L.A., and Schultz, J.E. (1994). membrane-bound protein phosphatase type 2C from Paramecium tetraurelia. Purification, characterization, and cloning. J Biol Chem., 1269(52): 32774-32780.

Klumpp, S. and Selke, D. (1998). Separation of protein phosphatase type 2C isozymes by chromatography on blue Sepharose. Methods in Molecular Biology, 93: 213-218.

Krinks, M.H., Klee, C.B., Pant, H.C., and Gainer, H. (1988). Identification and quantification of calcium-binding proteins in squid axoplasm. J Neurosci., (6): 2172-2182.

Kudo, N., Gillespie, J.G., Kung, L., Witters, L.A., Schulz, R., Clanachan, A.S., and Lopaschuk, G.D. (1996). Characterization of 5'AMP-activated protein kinase activity in the heart and its role in inhibiting acetyl-CoA carboxylase during reperfusion following ischemia.Biochim Biophys Acta. 1301(1-2): 67-75.

Land, S.C. and Bernier, N.J. (1995). Estivation: mechanisms and control of metabolic suppression. In: Biochemistry and Molecular Biology of Fishes (eds. P.W. Hochachka \& T.P. Mommsen), Vol. 5, pp. 381-412. Elsevier Science, Amsterdam.

Larade, K. and Storey, K.B. (2002). A profile of the metabolic responses to anoxia in marine invertebrates. In Sensing, Signaling and Cell Adaptation (eds. K.B. Storey and J.M. Storey), pp. 27-46. Amsterdam: Elsevier Science.

Larade, K. and Storey, K.B. (2004). Anoxia-induced transcriptional upregulation of sarp19: cloning and characterization of a novel EF-hand containing gene expressed in hepatopancreas of Littorina littorea. Biochem Cell Bio, 82(2): 285-93.

Larade, K. and Storey, K.B. (2006). Analysis of signal transduction pathways during anoxia exposure in a marine snail: A role for p38 MAP kinase and downstream signaling cascades. Comp. Biochem. Physiol., 143(B): 85-91.

Larini, A., Bianchi, L., and Bocci, V. (2004). Effect of 4-hydroxynonenal on antioxidant capacity and apoptosis induction in Jurkat T cells, Free Radical Res. 38: 509-516.

Li, D., Aperia, A., Celsi, G., da Cruz E Silva, E.F., Greengard, P. and Meister, B. (1995). Protein phosphatase- 1 in the kidney: evidence for a role in the regulation of medullary $\mathrm{Na}^{+} \mathrm{K}^{+}$-ATPase. Am. J. Physiol. 269, F673-F680.

Li, H.C., Hsiao, K.J. and Sampathkumar, S. (1979). Characterization of a novel alkaline phosphatase activity which co-purifies with a phosphorylase (phosphoprotein) phosphatase of $\mathrm{Mr}=35,000$ cardiac muscle. J. Biol. Chem. 254: 3368-3374.

Li, Y.M., Mackintosh, C., and Casida, J.E. (1993). Protein phosphatase 2A and its $[3 \mathrm{H}]$ cantharidin/[3H]endothall thioanhydride binding site. Inhibitor specificity of cantharidin and ATP analogues. Biochem Pharmacol. 46(8):1435-1443 
Liedtke, C.M., Wang, X. and Smallwood, N.D. (2005). Role for protein phosphatase 2A in the regulation of calu-3 epithelial $\mathrm{Na}^{+}-\mathrm{K}^{+}-2 \mathrm{Cl}^{-}$, type 1 co-transport function. $J$. Biol. Chem. 280: 25491-25498.

Lincoln, T.M., Dills, W.L., and Corbin, J.D. (1977). Purification and subunit composition of guanosine 3':5'-monophosphate-dependent protein kinase from bovine lung. $J$. Biol. Chem., 252(12): 4269-4275.

Lincoln, T.M., Thompson, M., and Cornwell, T.L. (1988). Purification and characterization of two forms of cyclic GMP-dependent protein kinase from bovine aorta. J. Biol. Chem., 263(33): 17632-17637.

Lincoln, T.M., Cornwell, T.L., Komalavilas, P., and Boerth, N. (1996). Cyclic GMPdependent protein kinase in nitric oxide signalling. Meth. Enzymology, 269: 14171 .

Lopina, O.D. (2001) Interaction of Na,K-ATPase catalytic subunit with cellular proteins and other endogenous regulators. Biochemistry (Moscow) 66: 1122-1131.

Mabrouk, G.M., Helmy, I.M., Thampy, G., and Wakil, S.J. (1990). Acute hormonal control of acetyl-CoA carboxylase. The roles of insulin, glucagon, and epinephrine. J. Biol. Chem. 265(11): 6330-6338.

MacDonald, J.A. (2004). Signal transduction pathways and the control of cellular responses to external stimuli. In: Functional Metabolism: Adaptation and Regulation. (ed. K.B. Storey), pp. 87-124.

MacDonald, J.A. and Storey K.B. (1999b). Cyclic AMP-dependent protein kinase: role in anoxia and freezing tolerance of the marine periwinkle, Littorina littorea. Marine Biology, 133: 193-203.

MacDonald, J.A. and Storey K.B. (1999a). Regulation of ground squirrel $\mathrm{Na}^{+} \mathrm{K}^{+}$-ATPase by reversible phosphorylation during hibernation. Biochemical and Biophysical Research Communications, 254: 424-429.

MacDonald, J.A. and Storey, K.B. (2002). Protein phosphatase type-1 from skeletal muscle of the freeze-tolerant wood frog. Comp. Biochem. Physiol. B., 131:27-36.

Macdonald, J.A. and Storey, K.B. (2005). Mitogen-activated protein kinases and selected downstream targets display organ-specific responses in the hibernating ground squirrel. Int J Biochem Cell Biol. 37(3): 679-691.

Macdonald, J.A. and Storey, K.B. (2006). Identification of a $115 \mathrm{kDa}$ MAP-kinase activated by freezing and anoxic stresses in the marine periwinkle, Littorina littorea. Arch. Biochem. Biophys., in press.

Matsuda, T. and Iwata, H. (1985). Species difference in temperature dependence of cardiac $\mathrm{Na}^{+} \mathrm{K}^{+}$-ATPase activity. Biochem. Pharmacol. 34, 2343-2346. 
McNall, S.J. and Fischer, E.H. (1988). Phosphorylase phosphatase. Comparison of active forms using peptide substrates. J. Biol. Chem. 263: 1893-1897.

McNall, S.J., Ballou, L.M., Villa-Moruzzi, E. and Fischer, E.H. (1988). Purification and characterization of phosphorylase phosphatase from rabbit skeletal muscle. Methods Enzymol. 159: 377-390.

Mehrani, H. and Storey, K.B. (1995a). Effects of anoxia on protein phosphatase in turtle organs: purification and properties of protein phosphatase type-1 from turtle liver. Arch. Biochem. Biophys. 316: 836-843.

Mehrani, H. and Storey, K.B. (1995b). cAMP-dependent protein kinase and anoxia survival in turtles: purification and properties of liver PKA. Mol. Cell. Biochem. 145: $81-88$.

Michaelidis, B. and Storey, K.B. (1990). Phosphofructokinase from the anterior byssus retractor muscle of Mytilus edulis: modification of the enzyme in anoxia and by endogenous protein kinases. Intl. J. Biochem. 22, 759-765.

Michaelidis, B. and Storey, K.B. (1991). Evidence for phosphorylation/dephosphorylation control of phosphofructokinase from organs of the anoxia-tolerant sea mussel Mytilus edulis. J. Exp. Zool. 257, 1-9.

Mobasheri, A., Avila, J., Cozar-Castellano, I., Brownleader, M.D., Trevan, M., Francis, M.J., Lamb, J.F. and Martin-Vasallo, P. (2000). $\mathrm{Na}^{+}, \mathrm{K}^{+}$-ATPase isozyme diversity; comparative biochemistry and physiological implications of novel functional interactions. Biosci. Reports 20, 51-91.

Moorhead, G., MacKintosh, C., Morrice, N. and Cohen, P. (1995). Purification of the hepatic glycogen-associated form of protein phosphatase-1 by microcystinSepharose affinity chromatography. FEBS Lett. 362: 101-105.

Mulkey, R.M., Endo S., Shenolikar, S., and Malenka, R.C. (1994). Involvement of a calcineurin/inhibitor-1 phosphatase cascade in hippocampal long-term depression. Nature, 369: 486-488

Munday, M.R. (2002). Regulation of mammalian acetyl-CoA carboxylase. Biochem Soc Trans. 30(Pt 6):1059-1064.

Nakamura, H. (2005).Thioredoxin and its related molecules: update 2005. Antioxid Redox Signal. 7(5-6): 823-828.

Napier, M.A., Lipari, M.T., Courter, R.G., and Cheng, C.H. (1987) Epidermal growth factor receptor tyrosine kinase phosphorylation of glucose-6-phosphate dehydrogenase in vitro. Arch Biochem Biophys 259: 296-304. 
Neumann, J., Maas, R., Boknik, P., Jones, L.R., Zimmermann, N. and Scholz, H. (1999). Pharmacological characterization of protein phosphatase activities in preparations from failing human hearts. J. Pharmaco. Exp. Ther. 289: 188-193.

Ofec, P., Ben-Meir, D., Karive-Inbal, Z., Oren., M., and Lavi S.(2003). Cell Cycle Regulation and p53 Activation by Protein Phosphatase 2C. Journal of Biological Chemistry, 278(16): 14299-14305.

Ohashi, I., Pohoreki, R., Morita, K., and Stemmer, P.M. (2004). Alcohols increase calmodulin affinity for $\mathrm{Ca} 2+$ and decrease target affinity for calmodulin.Biochim Biophys Acta. 1691(2-3): 161-167

Oldham, S, and Hafen, E. (2003). Insulin/IGF and target of rapamycin signaling: a TOR de force in growth control. Trends Cell Biol. 13(2): 79-85.

Oliver, C.J. and Shenolikar, S. (1998). Physiologic importance of protein phosphatase inhibitors. Frontiers in Bioscience, 3: D961-972

Orgad, S., Dudai, Y., and Cohen, P. (1987). The protein phosphatases of Drosophila melanogaster and their inhibitors. Eur J Biochem. 164(1): 31-38.

Orgad, S., Brewis, N.D., Alphey, L., Axton, J.M., Dudai, Y., and Cohen, P.T. (1990). The structure of protein phosphatase $2 \mathrm{~A}$ is as highly conserved as that of protein phosphatase 1. FEBS Lett. 275(1-2): 44-48.

Ozer, N., Bilgi, C. and Ogus H.I. (2002). Dog liver glucose-6-phosphate dehydrogenase: purification and kinetic properties. International Journal of Biochemistry and Cell Biology, 34: 253-262.

Palanivel, R., Veluthakal, R., McDonald, P., and Kowluru, A. (2005). Further evidence for the regulation of acetyl-CoA carboxylase activity by a glutamate- and magnesium-activated protein phosphatase in the pancreatic beta cell: defective regulation in the diabetic GK rat islet. Endocrine 26(1): 71-77.

Pan, D.A. and Hardie, D.G. (2002). A homologue of AMP-activated protein kinase in Drosophila melanogaster is sensitive to AMP and is activated by ATP depletion. Biochem J. 367(Pt 1): 179-86.

Park, C., and Marqusee, S. (2005). Pulse proteolysis: a simple method for quantitative determination of protein stability and ligand binding. Nature Methods 2, 207-212

Pfister, T.D. and Storey, K.B. (2002). Purification and characterization of protein phosphatase-1 from two cold-hardy goldenrod gall insects. Arch. Insect Biochem. Physiol. 49: 56-64.

Pfister, T.D. and Storey, K.B. (2006a). Responses of protein phosphatase and cAMP- 
dependent protein kinase in a freeze-avoiding insect, Epiblema scudderiana. Arch. Insect Biochem. Physiol. in press.

Pfister, T.D. and Storey, K.B. (2006b). Insect freeze tolerance: roles of protein phosphatases and protein kinase A. Insect Biochem. Mol. Biol. 36(1): 18-24

Pinna, L.A. and Donella-Deana, A. (1994). Phosphorylated synthetic peptides as tools for studying protein phosphatases. Biochim. Biophys. Acta. 1222: 415-431.

Polekhina, G., Feil, S.C., Gupta, A., O’Donnell, P., Stapleton, D., and Parker, M.W. (2005). Crystallization of the glycogen-binding domain of the AMP-activated protein kinase beta subunit and preliminary X-ray analysis. Acta Crystallograph Sect F Struct Biol Cryst Commun., 61(Pt 1): 39-42.

Pondaven, P. and Cohen, P. (1987). Identification of protein phosphatases-1 and 2A and inhibitor-2 in oocytes of the starfish Asterias rubens and Marthasterias glacialis. Eur. J. Biochem. 167: 135-140.

Ramos-Vasconcelos, G.R. and M. Hermes-Lima, M. (2003). Hypometabolism, antioxidant defenses, and free radical metabolism in the pulmonate land snail Helix aspersa, J. Exp. Biol. 206: 675-685.

Rees, B.B. and Hand, S.C. (1990). Heat dissipation, gas exchange and acid-base status in the land snail Oreohelix during short-term estivation. J. Exp. Biol. 152, 77-92.

Rees, B.B. and Hand S.C. (1993). Biochemical correlates of estivation tolerance in the mountainsnail Oreohelix (Pulmonata: Oreohelicidae). The Biology Bulletin, 184: $230-242$.

Richie-Jannetta, R., Francis, S.H., and Corbin, J.D. (2003). Dimerization of cGMPdependent protein kinase Ibeta is mediated by an extensive amino-terminal leucine zipper motif, and dimerization modulates enzyme function. J. Biol. Chem., 278(50): 50070-50079.

Rider, M.H., Hussain, N., Horman, S., Dilworth, S.M. and Storey, K.B. (2006). Stressinduced activation of the AMP-activated protein kinase in the freeze-tolerant frog Rana sylvatica. Cryobiology, in press.

Rivas, M., Garcia, C., Liberona, J.L., and Lagos, N. (2000). Biochemical characterization and inhibitory effects of dinophysistoxin-1, okadaic acid and microcystine 1-r on protein phosphatase 2a purified from the mussel Mytilus chilensis. Biol Res. 33(34): $197-206$.

Rogers, J.P, Beuscher, A.E., Flajolet, M., McAvoy, T., Nairn, N.C., Olson, A.J., and Greengard, P. (2006). Discovery of protein phosphatase $2 \mathrm{C}$ inhibitors by virtual 
screening. J Med Chem., 49(5): 1658-1667.

Sailaja, R., Baskar, R., and Sarakalumari, D. (2003) The antioxidant status during maturation of reticulocytes to erythrocytes in type 2 diabetes, Free Rad. Biol. Med. 35: 133-139.

Samari, H.R., Moller, M.T., Holden, L., Asmyhr, T., and Seglen, P.O. (2005). Stimulation of hepatocytic AMP-activated protein kinase by okadaic acid and other autophagy-suppressive toxins. Biochem J. 386(Pt 2): 237-244.

Sampson, S.R., Brodie, C. and Alboim, S.V. (1994). Role of protein kinase C in insulin activation of the Na-K pump in cultured skeletal muscle. Am. J. Physiol. 266, C751-758Schlossmann, J., Feil, R., and Hoffman, F. (2003). Signaling through NO and cGMP-dependent protein kinases.Ann Med., 35(1): 21-27.

Schmidt, H. H., Lohmann, S.M.,and Walter, U.. (1993). The nitric oxide and cGMP signal transduction system: regulation and mechanism of action. Biochim. Biophys. Acta, 1178:153-175

Selke, D., Anton, H., and Klumpp, S. (1998). Serine/Threonine Protein Phosphatases Type 1,2A and 2C in Vertebrate Retinae. Acta Anatomica, 162: 151-156.

Sharma, S.K, Bagnall, M.W., Sutton, M.A., and Carew, T.J. (2003). Inhibition of calcineurin facilitates the induction of memory for sensitization in Aplysia: requirement of mitogen-activated protein kinase. Proc Natl Acad Sci U S A.100(8): 4861-4866.

Shenolikar, S. (1994). Protein serine/threonine phosphatases-new avenues for cell regulation. Annual Review of Cell Biology, 10: 55-86.

Shiozaki, K. and Russell, P. (1994). Cellular function of protein phosphatase 2C in yeast. Cell. Mol. Biol. Res. 40: 241-243.

Signorile, A., Sardanelli, A.M., Nuzzi, R., and Papa, S. (2002). Serine (threonine) phosphatase(s) acting on cAMP-dependent phosphoproteins in mammalian mitochondria. FEBS. Lett. 512(1-3): 91-94.

Silberman, S.R., Speth, M., Nemani, R., Ganapathi, M.K., Dombradi, V., Paris, H. and Lee, E.Y. (1984). Isolation and characterization of rabbit skeletal muscle protein phosphatases C-I and C-II. J. Biol. Chem. 259: 2913-1922.

Slekar, K.H., D.J. Kosman, D.J., and Culotta, V.C. (1996)The yeast copper/zinc superoxide dismutase and the pentose phosphate pathway play overlapping roles in oxidative stress protection, J. Biol. Chem. 271: 28831-28836.

Spolarics, Z. (1998). Endotoxemia, pentose cycle, and the oxidant/antioxidant balance in the hepatic sinusoid. Journal of Leukocyte Biology, 63: 534-541. 
Stamler, J.S., and Meissner, G. (2001). Physiology of nitric oxide in skeletal muscle. Physiol. Rev. 81: 209-237.

Stein, S.C., Woods, A., Jones, N.A., Davison, M.D., and Carling, D. (2000). The regulation of AMP-activated protein kinase by phosphorylation. Biochem. J., 345 Pt 3: 437-443.

Stephenson, G.M. (1991). A comparative study of the microsomal S6 phosphatase and phosphorylase phosphatase activities in rat liver. Arch. Biochem. Biophys. 289: 324-328

Stock, J. and Da Re, S. (2000). Signal transduction: response regulators on and off. Curr Biol., 10(11):R420-4.

Stokoe, D., Campbell, D.G., Nakielny, S., Hidaka, H., Leevers, S., Marshall, C., and Cohen, P. (1992). MAPKAP kinase-2: A novel protein kinase activated by mitogen-activated protein kinase. EMBO. J. 11: 3985-3994.

Storey, K.B. (1988). Mechanisms of glycolytic control during facultative anaerobiosis in a marine mollusc: tissue specific analysis of glycogen phosphorylase and fructose-2,6-bisphosphate. Canadian Journal of Zoology, 66: 1767-1771.

Storey, K.B. (1994). Analysis of enzyme regulation by reversible phosphorylation. In Biochemistry and Molecular Biology of Fishes (eds. P.W. Hochachka and T.P. Mommsen). Vol. 3, pp. 603-614. Amsterdam: Elsevier Science.

Storey, K.B. (2001). Turning down the fires of life: metabolic regulation of hibernation and estivation. In: Molecular Mechanisms of Metabolic Arrest (Storey, K.B., ed.) BIOS Scientific Publishers, pp. 1-21.

Storey, K.B. (2002). Life in the slow lane: molecular mechanisms of estivation. Comparative Biochemistry and Physiology, A 133: 733-754

Storey, K.B. (2006). Genomic and proteomic approaches in comparative biochemistry and physiology. Physiol. Biochem. Zool, in press.

Storey, K.B. and Storey, J.M. (2004). Metabolic rate depression in animals: transcriptional and translational controls. Biological reviews of the Cambridge Philosophical Society, 79: 207-233.

Sung, Y.J., Walters, E.T., and Ambron, R.T. (2004). A neuronal isoform of protein kinase $\mathrm{G}$ couples mitogen-activated protein kinase nuclear import to axotomyinduced long-term hyperexcitability in Aplysia sensory neurons. J Neurosci. 24(34):7583-7595. 
Szoor, B., Feher, Z., Bako, E., Erdodi, F., Szabo, G., Gergely, P., and Dombradi, V. (1995). Isolation and characterization of the catalytic subunit of protein phosphatase 2A from Neurospora crassa. Comp. Biochem. Physiol. B. Biochem. Mol. Biol. 112(3): 515-522.

Tamarappoo, B.K. Yang, B., and Verkman, A.S.(1999). Misfolding of mutant aquaporin2 water channels in nephrogenic diabetes insipidus, J. Biol. Chem. 274: 3482534831.

Testa, J.R. and Tsichlis, P.N. (2005). AKT signaling in normal and malignant cells. Oncogene, 24(50): 7391-7393.

Thoen, C., Van Hove, L., and Slegers, H. (1987). Purification, subunit structure and properties of a high-molecular-mass protein phosphatase capable of dephosphorylating mRNP of the brine shrimp Artemia sp. Eur J Biochem., 163(3): 503-511.

Tian, W., Braunstein, L.D., Pang, J., Stuhlmeier, K.M., Xi, Q.C., Tian, X., and Stanton, R.C. (1998) Importance of glucose-6-phosphate dehydrogenase activity for cell growth. J. Biol. Chem. 273: 10609-10617.

Tian, W., Braunstein, L.D., Apse, K., Pang, J.,Rose, M., Tian, X., and Stanton, R.C. (1999). Importance of glucose-6-phosphate dehydrogenase activity in cell death. Am. J. Physiol. 276: C1121-C1131.

Toth, B., Bollen, M. and Stalmans, W. (1988). Acute regulation of hepatic protein phosphatases by glucagon, insulin, and glucose. J. Biol. Chem. 265: 1406114066.

Tung, P., Pai, G., Johnson, D.G., Punzalan, R., and Levin, S.R. (1990). Relationships between adenylate cyclase and $\mathrm{Na}^{+}, \mathrm{K}^{+}$-ATPase in rat pancreatic islets. $J$. Biol. Chem. 265, 3936-3939.

Ursini, M.V., Parella, A., Rosa, G., Salzano, S. and Martini, G. (1997). Enhanced expression of glucose-6-phosphate dehydrogenase in human cells sustaining oxidative stress, Biochem. J. 323: 801-806.

Vaandrager, A.B., and de Jonge, H.R. (1996).Signalling by cGMP-dependent protein kinases. Molecular and Cellular Biochemistry, 157: 23-30.

Vasilets, L.A. and Schwarz, W. (1992). Regulation of endogenous and expressed Na/Kpumps in Xenopus oocytes by membrane potential and stimulation of protein kinases. J. Membr. Biol. 125, 119-132.

Warden, S.M., Richardson, C., O’Donnell, J. Jr., Stapleton, D., Kemp, B.E., and Witters, L.A. (2001). Post-translational modifications of the beta-1 subunit of AMP- 
activated protein kinase affect enzyme activity and cellular localization. Biochem

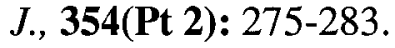

Warmka, J., Hanneman, J., Lee, J., Amin, D., and Ota I. (2001). Ptc1, a Type 2C Ser/Thr Phosphatase, Inactivates the HOG Pathway by Dephosphorylating the MitogenActivated Protein Kinase Hog1. Molecular and Cellular Biology, 21(1): 51-60

Winder, W.W., Wilson, H.A., Hardie, D.G., Rasmussen, B.B., Hutber, C.A., Call, G.B., Clayton, R.D., Conley, L.M., Yoon, S., and Zhou, B. (1997). Phosphorylation of rat muscle acetyl-CoA carboxylase by AMP-activated protein kinase and protein kinase A. J. Appl. Physiol. 82(1): 219-225.

Wingrove, J.A. and O'Farrell, P.H. (1999). Nitric oxide contributes to behavioral, cellular, and developmental responses to low oxygen in Drosophila. Cell 198(1):105-114.

Withers, P.C. and Guppy, M. (1996). Do Australian desert frogs co-accumulate counteracting solutes with urea during aestivation? Journal of Experimental Biology, 199(8): 1809-1816.

Whitwam, R.E. and Storey, K.B. (1990). Pyruvate kinase from the land snail Otala lactea: Regulation by reversible phosphorylation during estivation and anoxia. Journal of Experimental Biology, 154: 321-337.

Whitwam, R.E. and Storey, K.B. (1991). Regulation of phosphofructokinase during estivation and anoxia in the land snail, Otala lactea. Physiological Zoology, 64(2): 595-610.

Xu, Y., Osborne, B.W., and Stanton, R.C. (2005). Diabetes causes inhibition of glucose6-phosphate dehydrogenase via activation of protein kinase A which contributes to oxidative stress in rat kidney cortex, Am. J. Physiol. 289(5): F1040-1047.

Yamada, A., Yoshio, M., Nakamura, A., Kohama, K, and Oiwa, K. (2004). Protein phosphatase $2 \mathrm{~B}$ dephosphorylates twitchin, initiating the catch state of invertebrate smooth muscle. J Biol Chem., 279(39): 40762-40768.

Yasuma, Y., McCarron, R.M., Spatz, M., and Hallenbeck, J.M. (1997). Effects of plasma membrane from hibernating ground squirrel on monocyte-endolthelial cell adhesive interactions. American Journal of Physiology, 273: R1861-1869.

Zabrocki, P., Swiatek, W., Sugajska, E., Theyelein, J.M., Wera, S., and Zolnierowicz, S. (1995). The Saccharomyces cerevisiae type 2A protein phosphatase Pph22p is biochemically different from mammalian PP2A. Eur J Biochem. J. 269(14): 3372-3382.

Zhang, Z.Y., Tieme-Sefler, A.M., Maclean, D., McNamara, D.J., Dobrusin, E.M., 
Sawyer, T.K., and Dixon, J.E. (1993). Substrate specificity of protein tyrosine phosphatases. Proc Natl Acad Sci USA 90: 4446-4450.

Zhang, L. and Lee, E.Y. (1997). Mutational analysis of substrate recognition by protein phosphatase 1. Biochemistry 36: 8209-8214.

Zhang, Z., Apse, K., Pang, J., and Stanton, R.C. (2000). High glucose inhibits glucose-6phosphate dehydrogenase via cAMP in aortic endothelial cells. Journal of Biological Chemistry, 275(51): 40042-40047.

Zinn, K. (1993). Drosophila protein tyrosine phosphatases. Semin Cell Biol., 4(6): 397401.

Zolnierowicz, S. (2000). Type 2A protein phosphatase, the complex regulator of numerous signaling pathways. Biochem. Pharmacol. 60: 1225-1235. 